\title{
ESTUDO DO POTENCIAL GENÉTICO DE DUAS RAÇAS BRASILEIRAS DE MILHO (Zaa mays L.) PARA FINS DE MELHORAMENTO
}

\author{
MANOEL XAVIER DOS SANTOS
}

Orientador: JOSÉ BRANCO DE MIRANDA FILHO

\begin{abstract}
Tese apresentada à Escola Superior de Agricultura "Luiz de Queiroz", da Universidade de São Paulo, para obtenção do título de Doutor em Agronomia. Área de Concentração: Genética e Melhoramento de Plantas.
\end{abstract}

PIRACICAB A

Estado de São Paulo - Brasil

Setembro - 1985 
Aos meus pais,

Tarcizo I in memoriam I e Helena,

DEDICO.

Para minha espôsa e filhos, OFEREÇO. 


\section{AGRADECIMENTOS}

o autor manifesta os mais sinceros agradeci mentos a todos que direta ou indiretamente contribuiram para a realização do presente trabalho, especialmente às seguintes pessoas e instituições:

- Prof. Dr. José Branco de Miranda Filho, pelos ensinamentos e pela segura orientação na realização deste trabalho;

- Empresa Brasileira de Pesquisa Agropecuāria (EMBRAPA), pela concessão de mais uma oportunidade, pelas fa cilidades e apoio durante todo o curso;

- Dr. Cláudio Lopes de Souza Junior, pelas vą liosas sugestões e ajuda no transcorrer de todo o trabalhoe, essencialmente, pela grande amizade;

- Centro de Pesquisa Agropecuária do Trópico Semi-Ārido (CPATSA/EMBRAPA), pela liberação para efetuar o curso;

- Professores do Departamento de Genética da ESALQ, pela atenção e ensinamentos;

- Isaias, Aline, Irajá, Eleusio, Paulo Gonçal ves, Bene, Fátima, Pedro, Ângela e lia, pela amizade.

- Funcionários do Departamento de Genética,pe 1 as gentilezas;

- Colegas de curso, pelo companheirismo. 
iv.

\section{INDICE}

pägina

RESUMO $\ldots \ldots \ldots \ldots \ldots \ldots \ldots \ldots$

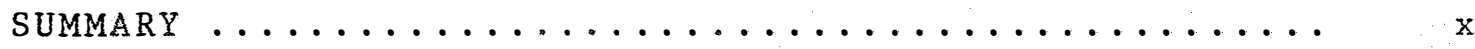

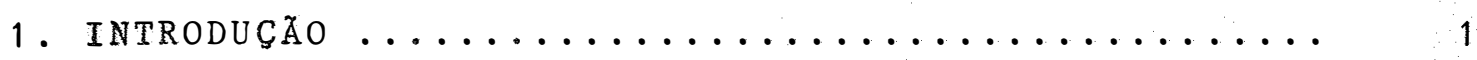

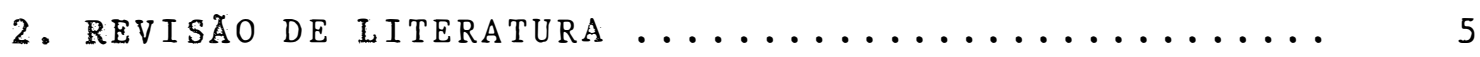

2.1. Variabilidade genética do milho .......... 6

2.1 .1 . Produção ................... 6

2.1.2. Caracteres da planta............ 10

2.1.3. Caracteres da espiga ............. 16

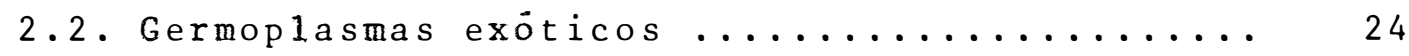

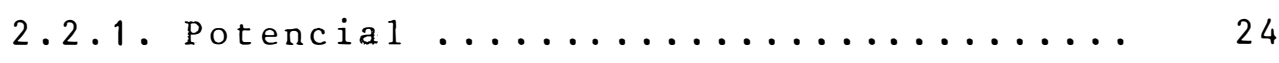

2.2.2. Metodologias e resultados obtidos .... 30

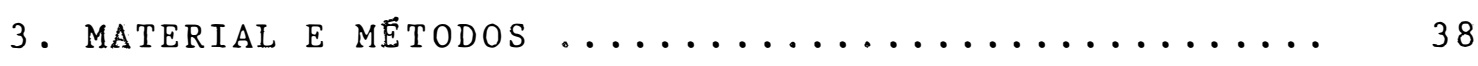

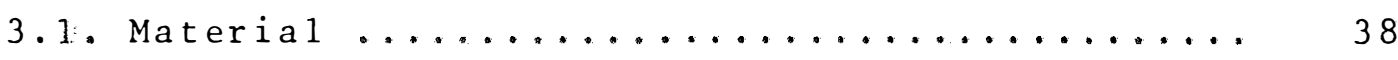

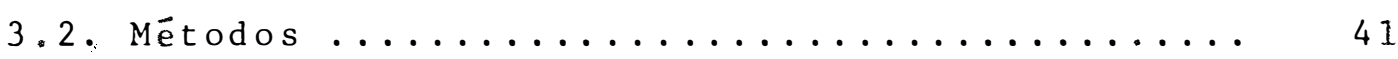

3.2.1. Cruzamentos e obtenção das famỉilias de meios irmãos .................. 41

3.2.2. Execução experimenta1 ........... 42

3.2.3. Anälise estatistico-genética ....... 46

3.2.4. Estimativas dos componentes de variância ..................... 47

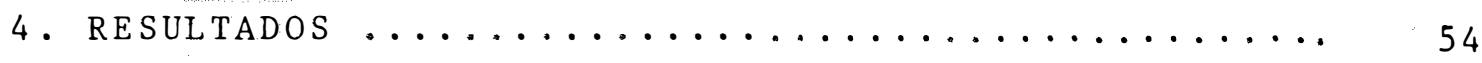

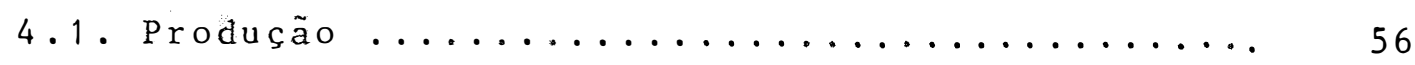

4.1 .1 . Análise geral .................. 56

4.1.2. Estimativas de parämetros genéticos... 59

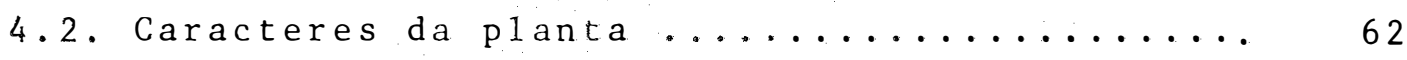

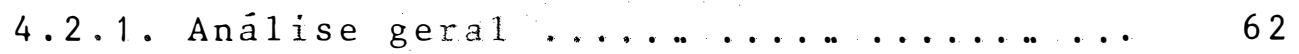

4.2.2. Estimativas de parämetros genéticos .. 63

4.3. Caracteres da espiga .................... 66

4.3.1. Análise geral .................. 66

4.3.2. Estimativas de parāmetros genéticos .. 67

5. DISCUSS

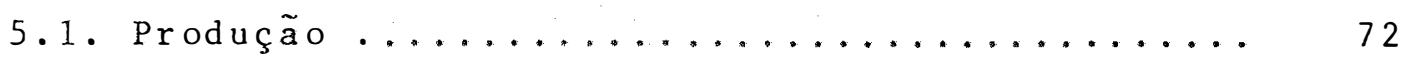


5.1.1. Avaliação geral para peso de espigas. .

5.1.2. Estimativas de parâmetros genéticos para peso de espigas ............ 75

5.1.3. Avaliação geral para peso de grãos...

5.1.4. Estimativas de parâmetros genéticos pa

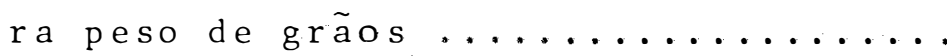

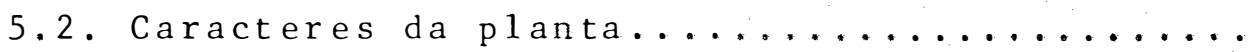

5.2.1. Avaliação geral para altura da planta

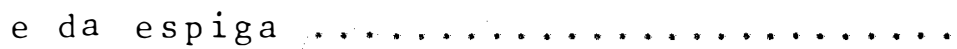

5.2.2. Estimativas de parâmetros genéticos pa ra altura da planta e da espiga .....

5.2.3. Avaliação geral para nûmero de ramifi-

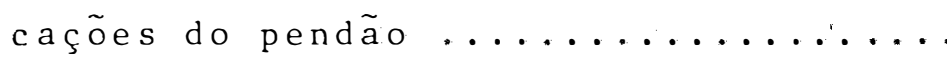

5.2.4. Estimativas de parâmetros genéticos pâ ra número de ramificações do pendão..

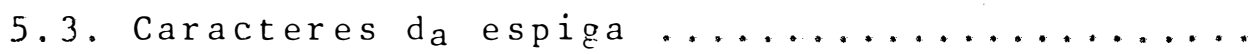

5.3.1. Avaliação gera 1 para comprimento da es

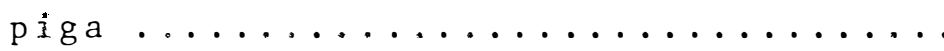

5.3.2. Estimativas de parâmetros genéticos pa ra comprimento da espiga .......... 100

5.3.3. Avaliação geral para número de grãos por fileira e número de fileiras por

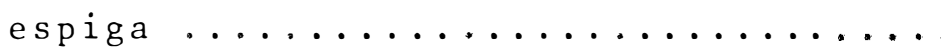

5.3.4. Estimativas de parâmetros genéticos pa ra nūmero de grãos por fileira e número de fileiras por espiga ......... 106

5.3.5. Avaliação geral para diâmetro da espigas e do sabugo .................. 109

5.3.6. Estimativas de parâmetros genéticos pa ra diâmetro da espiga e do sabugo ....

5.4. Considerações finais ................ 112

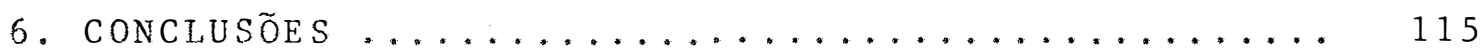

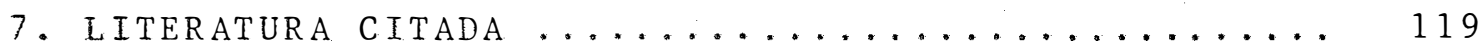


. vi.

pāgina

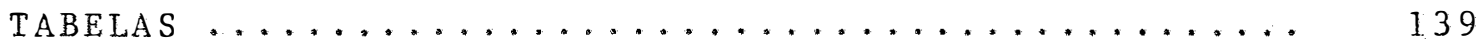

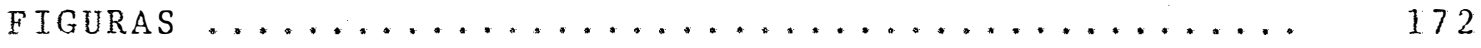




\title{
ESTUDO DO POTENCIAL GENÉTICO DE DUAS RACAS BRASILEIRAS DE MILHO (Zea mays L.) PARA FINS DE MELHORAMENTO
}

\author{
Autor: MANOEL XAVIER DOS SANTOS \\ Orientador: JOSÉ BRANCO DE MIRANDA FILHO
}

\section{RESUMO}

O presente trabalho teve por objetivo estudar a potencialidade genética das raças brasileiras de milho Cra vo e Entrelaçado, cujas caracteristicas marcantes são, respectivamente, o grande número de fileiras por espiga e o acentuado comprimento de espi६a. Para atingir este objetivo, de cada uma destas raças exóticas, foi efetuada a incorporação de 50\% de genes na população melhorada e adaptada ESALQ-PB1, a fim de verificar as mudanças ocorridas nas médias e nas estimativas dos parảmetros genēticos das populações resultantes do cruzamento, em relação à população adaptada.

Após o cruzamento inicial, foram realizadas

duas recombinações, obtendo-se, desta maneira, as pop u 1 ações semi-exöticas Cravo x ESALQ-PB1 (EC) e Entrelaçado $x$ ESALQ-PB1 (EE). De cada uma destas populações foram escolhi das 196 familias de meios irmãos, que com outras 196 fami1 ias de meios irmãos da população ESALQ-PB1 (E), se constituiram no material experimental.

As 196 familias das populações E, EC e EE foram avaliadas no municipio de Piracicaba-SP, em dois distritos (locais): Caterpillar e Água Santa, no ano agricola de 1983/84. Foram instalados 4 experimentos, para cada uma das populações, no delineamento em lätice triplo $7 \times 7, \operatorname{com} 3$ re petições por 1ocal. 


$$
\text { viii. }
$$

$$
\text { Para cada uma das populações, foram avaliados }
$$

os seguintes caracteres; peso de espigas e de grãos, três caracteres de planta e cinco caracteres de espiga, sendo que em Água Santa apenas foram considerados os caracteres peso de espigas e peso de grãos.

Considerando os caracteres peso de espigas e peso de grãos, verificou-se que, em relação às médias da população adaptada, houve um decréscimo nas médias das po pulações semi-exóticas EC e EE, tendo-se, porém, constatado o efeito positivo da incorporação de genes exóticos para aumentar a variabilidade genética das duas populações semi-exó ticas .

Com relação aos caracteres de planta, foram observados os beneficios resultantes da introgressão de genes da raça Cravo, tendo em vista que as médias obtidas para altura de planta, altura de espiga e nümero de ramificaçós do pendão foram mais baixas que as da população adaptada, ocorrendo o inverso para a popuíação semi-exötica EE. Por ou tro lado, os valores relativamente altos encontrados para as estimativas de paràmetros genéticos, mostraram que para as duas populações semi-exóticas, hả possibilidades de serem conseguidos ganhos substanciais com esquemas simples de sele ção .

Entre os caracteres da espiga, as mudanças po sitivas ocorridas nas médias das populações semi-exóticas EC e EE foram, respectivamente, para numero de fileiras por espiga e comprimento da espiga, uma vez que a população adapta da apresentou médias mais baixas. Por outro lado, verificou-se que para ambos os caracteres, as magnitudes relativas dos parâmetros genéticos estimados das populações semi-exóti cas foram maiores que as da população adaptada, ressaltando a potencialidade genética para programas de melhoramento. 
Embora as médias obtidas para nümero de grãos por fileira, diâmetro da espiga e do sabugo terem sido mais ou menos semelhantes nas trés populações, constatou-se, de um modo geral, uma maior variabilidade e potencialidade gené tica para as populações semi-exóticas que para a população adaptada ESALQ-PB1.

Considerando a estrutura genética de cada uma das raças exöticas, e tendo por base os resultados obtidos, recomenda-se o aproveitamento da potencialidade genética apresentada pela população semi-exótica EC para programas de melhoramento a curto prazo, enquanto que a população EE pode rä ser aproveitada para programas a longo prazo. 


\title{
STUDY OF GENETIC POTENTIAL OF TWO BRAZILIAN \\ RACES OF CORN (zea mays L.) FOR BREEDING
}

\author{
Author: MANOEL XAVIER DOS SANTOS \\ Adviser: JOSÉ BRANCO DE MIRANDA FILHO
}

\section{SUMMARY}

The aim of the present work was to study the breeding potential of the Brazilian races "Cravo" and "Entre laçado" of corn. Their principal characters are high number of kernels rows per ear and long ear, respectively. To evaluate their potential, the theoretical proportion. of $50 \%$ of their genes was incorporated to the adapted ESALQ-PB 1 population, and their effects on mean and genetic parameters estimates were determined in relationship to the adapted population.

Following the initial crosses two recombination phases were performed to produce generations of the crosses Cravo $x$ ESALQ-PB1 (EC) and Entrelaçado x ESALQ-PB1 (EE). The 196 half-sib families were then extracted from each population, and together with 196 half-sib families obtained from ESALQ-PB1 (E), constituted the experimental material. These families were evaluated at two locations (Caterpillar and Ågua Santa) within Piracicaba -SP, in 1983/84. Four trials were established for each population, and the experimental design was a $7 \times 7$ triple lattice, with 3 replications per location.

For each population were studied: ear weight, kernel yield, three plant morphological characters and five ear characters, except for Agua Santa, where only 
ear weight and kernel yield were considered.

Decrease on mean values for ear weight and kernel yield was detected in EC and EE, whereas an increase in genetic variability was observed from the incorporation of the exotic genes in ESALQ-PB1, for those characters, as compared to the adapted populations.

For plant characters, the effects were beneficial in EC, since mean plant height, mean ear height and mean of tassel branch number were lower than those of ESALQ-PB 1, being the opposite detected from EE. High genetic parameters estimates found for those characters suggestes that simple selection schemes would be effective in improving mean populational in these populations.

For ear characters, kernel rows per ear and ear lenght showed superior mean values in EC and EE in comparison to the adapted population. High estimates for the genetic parameters studied were obtained, suggesting high genetic potential of those populations for improvement of such characteristics.

Although mean values for number of kernels per row, ear diameter and cob diameter have been of similar magnitude in EC, EE and E, the genetic variability was greater in EC and EE.

With basis on the genetic structural of each of exotic races and on the results obtained, it is suggested the utilization of the populations EC in short-termbreeding programs and EE in long-term breeding programs. 


\section{INTRODUCĀAO}

o milho é cultivado em todas as äreas agricolas do mundo, e se constitui em uma cultura de importáncia economica para todos os povos. Seu cultivo é realizado desde $58^{\circ}$ de latitude norte até $40^{\circ}$ de latitude sul, desenvolvendo-se também desde o'nivel do mar até altitudes superiores a $3.800 \mathrm{~m}$, e em regiões que apresentam precipitações plü viométricas variando de $250 \mathrm{~mm}$ a $1.000 \mathrm{~mm}$ (HALLAUER e MIRANDA FILHO, 1981).

A morfologia e nümero bastante uniformes dos seus cromossomos, apesar da grande diversidade dos tipos de milhos existentes, têm favorecido cruzamentos entre fontes de germoplasmas adaptados e não adaptados (exóticos), tornan do possivel o seu desenvolvimento em variadas condições ambientais e possibilitando a seleção de tipos para cada nicho ecológico. Esta variação de tipos de milho tem evoluido atra vés do processo natural de mutação, hibridação e seleção, na tural ou artificial, desde as fases de evolução e domesticação da espécie, até as fases atuais de cultivo e melhoramento.

A preservação destes diferentes tipos de germoplasmas, tem merecido, recentemente, a atenção por parte 
de örgãos governamentais e entidades privadas, podendo-se sa lientar que somente no Hemisfério ocidental existem aproxima damente 12.000 acessos disponiveis, e destes, cerca de 250 raças foram descritas (HALlaUER e MIRANDA FILHO, 1981).

Graças ao aproveitamento desta ampla variabilidade genética é que os melhoristas conseguiram elevar a produtividade da cultura e obter cultivares de milho altamen te uniformes e eficientes, para os sofisticados e avançados sistemas de produção. Em parte, isto foi benéfico; mas, uma consequéncia deste sucesso foi o estreitamento da base genética populacional, resultando no que se pode chamar de ero são genética (JENSEN, 1962).

Esta tendência foi intensificada na década de 60 (BENNET, 1970; MILLER, 1973), gerando uma violenta vulnerabilidade para a cultura, conforme foi constatado pelo surto da Helminthosporiose de 1970, e ocasionando perdas relativamente a1tas na produção de milho híbrido, principalmente nos Estados Unidos.

Logo apös isto, houve o despertar do interesse em desenvolver populações geneticamente variáveis, tendo em vista que o progresso do melhoramento está relacionadocom a quantidade de variação genética. Se a variabilidade genëtica não estiver presente na população, a seleção não será eficiente e nem haverà progresso. Assim sendo, os melhoris tas têm estado constantemente à procura de caminhos para aumentar a variabilidade genética das populações.

Os mecanismos utilizados para criar variabili dade genética incluem hibridação de materiais adaptados, uso de agentes mutagênicos, bem como a introdução de materiais não adaptados de outras fontes. Estes materiais oriundos de outras fontes, comumente designados de exöticos, hä muito 
tempo foram enfatizados como potencialmente úteis nos progra mas de melhoramento (BROWN, 1953; GRIFFIng e LINDSTROM, 1954; WELLHAUSEN, 1965), para aumentar a variabilidade genética das populações.

Muitos destes germoplasmas exóticos contêm uma grande quantidade de variação genética ūtil para caracte res herdados quantitativamente, e frequentemente têm sido cruzados com uma população melhorada e adaptada para produzir uma nova população (semi-exötica).

No Brasil, BRIEGER et alii (1958), PATERNIANI e GOODMAN (1977) relataram os estudos que foram feitos com diversas raças de milho e forneceram indicacooes daquelas mais promissoras para os programas de melhoramento. Entre as raças exōticas, potencialmente ùteis, destacaram-se a Cravo e Entrelaçado por apresentarem caracteres particulares, quais sejam, respectivamente, grande nümero de fileiras de grãos e maior comprimento de espiga.

A inclusão de qualquer um destes caracteres em uma população jä melhorada e adaptada, pode levar futuramente a um acréscimo significativo da produção, uma vez que tais caracteres são reconhecidos como associados à produção. Espera-se, assim, que a presença do germoplasma adaptado evite mudanças bruscas e negativas na média, e que a presença do germoplasma exótico aumente a variabilidade ge nética na nova população, tanto para produção quanto para ca racteres da planta e espiga.

Desta maneira, a incorporação de genes de cada uma das duas raças brasileiras de milho dentro de uma população reconhecidamente melhorada e adaptada (ESALQ-PB1), se constituiu nos objetivos do presente estudo, procurando-se: 
1. verificar as mudanças ocorridas nas médias das duas popu1 ações resultantes (semi-exóticas), em relação à população melhorada;

2. determinar a potencialidade genética das duas raças exóti cas para fins de melhoramento, comparando-se as estimativas dos parāmetros genéticos das populações semi-exóticas com as estimativas da população adaptada, a fim de se verificar o efeito da incorporaça de genes na variabilidade genética;

3. aumentar o limitado conhecimento sobre o efeito da introgressão de germoplasmas exóticos. 


\section{REVISÃo DE LITERATURA}

Em decorrēncia da extensão do trabalho, efetuou-se uma revisão de literatura abrangendo os vārios aspec tos relacionados com os objetivos do presente estudo. Em pri meiro lugar, foi dado um enfoque sobre a variabilidade genética do milho considerando a produção, caracteres da planta e da espiga. Em segundo lugar, foi enfatizado a respeito dos germoplasmas exóticos, com uma abordagem mais ampla sobre o potencial genëtico no melhoramento, salientando-se, f nalmente, as metodologias e resultados obtidos com a utiliza ção de germoplasmas exóticos.

Considerando que, de um modo geral, o potencial genético de populações de milho tem sido avaliado através de estimativas dos componentes de variaça fenotípica, foi dada ēnfase especial para a estimativa da variação genética aditiva dos diversos caracteres, e quando possive1, para as estimativas associadas à variāncia genética aditiva, tais co mo, coeficiente de variação genética, coeficiente de herdabi lidade, indice de variação e do progresso esperado, uma vez que são também indicadores da variabilidade genética. 
2.1. Variabilidade genética do milho

\subsubsection{Produção}

O aumento da produtividade do milho sempre se constituiu em um dos objetivos primordiais por parte dos melhoristas. Para atingir este objetivo, torna-se necessário a existéncia de suficiente variabilidade genética na população. No entanto, os resultados iniciais encontrados com o método de seleção massal e espiga por fileira foram pouco con sistentes, levando os pesquisadores a darem maior ēnfase na obtenção de híbridos simples para o aumento da produtividade. A viabilização para o uso comercial de milhos híbridos foi concretizada quando Jones (1918) sugeriu ó método para forma ção do híbrido duplo. Observou-se, porém, "que a partir da década de 30 os novos híbridos não se mostraram muito superiores aos existentes, o que levou HULL (1945) a sugerir que a vạ riância genética aditiva para a produção havia sido esgotada.

Apesar da partição da variação genética em seus efeitos aditivos, dominantes e epistáticos ter sido efe tuada por FISHER (1918), as estimativas destes componentes somente se revestiram de especial significado para o milho, quando foram sugeridos por COMSTOCK e ROBINSON (1948 e 1952) os delineamentos genético-estatisticos I, II e III. Os primeiros resultados obtidos com a utilização do delineamento I foram apresentados por ROBINSON et a $2 i i$ (1955), onde evidenciaram a existência de suficiente variabilidade genética adi tiva, capaz de se conseguir progressos com a seleção, mesmo com o uso de métodos simples como é o caso da seleção massal. Tornou-se, então, reconhecido que a ineficiência da se leção massal e do método espiga por fileira eram decorrentes de problemas técnicos, tais como, falta de isolamento, falta de técnicas experimentais adequadas, amostra populacional 
ètc. (GARDNER, $1961 ;$ LONNQUIST, 1961).

Houve, desta forma, o ressurgimento pelo interesse do melhoramento de populações, sendo introduzidas a 1 gumas inovações nos métodos já conhecidos, que possibilitariam um melhoramento gradativo e continuo, bem como uma exploração mais ampla do potencial genético.

A presença de variabilidade genética aditiva tem sido confirmada em diversas populações de milho, haja visto que progressos com a seleção têm sido obtidos com dife rentes esquemas de melhoramento intrapopulacional (LONNQUIST, 1961; MOLL et alii, 1966; MOLL e ROBINSON, 1966; HALLAUER e WRIGHT , 1967; LONNQUIST, 1967 ; WEBEL e LONNQUIST, 1967 ; GARD NER，1969; MOLL e STUBER, 1971; DARRAH et ali , 1972; CUNHA, 1976 ; COMPTON e BAHADUR, 1977 ; CRISÓSTOMO, 1978 ; LORDELO, 1982 ; SOUZA JUNIOR, 1983, entre outros).

Informações recentes fornecidas por HALLAUER e MIRANDA FILHO (1981), que realizaram um levantamento das estimativas da variāncia genética aditiva ( $\hat{\partial}_{\mathrm{A}}^{2}$ ) e dominante $\left(\hat{\sigma}_{D}^{2}\right)$ em 99 trabalhos e para cinco tipos de populações, vieram mostrar claramente a existência de suficiente variabilidade genética aditiva para produção. Em todas populações constataram estimativas mais altas para as variâncias genéti cas aditivas, obtendo uma média de 468,8 (g/p 1$)^{2}$ e 279,9 (g/ p1) ${ }^{2}$ para a $\hat{\sigma}_{A}^{2}$ e $\hat{\sigma}_{D}^{2}$, respectivamente.

0 potencial genético de vārias populações de milho tem sido avaliado em programas de seleção com o método "espiga por fileira modificado" (LONNQUIST, 1964) ou "seleção entre e dentro de familias de meios irmãos" (PATERNIANI, 1967). Assim sendo, as familias de meios irmãos avaliadas prestam-se como unidades de seleção e como unidades para a estimação da variância genētica aditiva. 
Este método, apesar de não haver possibilidade de se estimar a variāncia dominante, tem sido bastante utilizado tanto no Brasil quanto no exterior. Sua grande vantagem, porém, è a possibilidade de obtenção da estimativa da variāncia genética aditiva, tendo em vista os valiosos subsiduos que fornece ao melhorista, uma vez que permite verificar quais as chances de éxito na seleça, e quais as alterações que podem ocorrer na variabilidade genética no decorrer dos sucessivos ciclos de selecão.

Uma série de trabalhos, encontrados na litera tura americana, mostra a existēncia de variabilidade genética após sucessivos ciclos de seleção, e a presença de ganhos continuos com a utilização deste método (GARDNER, 1961; WEBEL e LONNQUIST, 1967 ; CHI et a $i i i$, 1969 ; MARQUEZ-SANCHEZ, 1970 ; SENTZ, 1971; DARRAH et a $i i i, 1972$; SILVA e HALLAUER, 1975; COMPTON e BAHADUR, 1977, entre outros).

O exemplo clássico que pode ser mencionado, é o citado por DUdLey (1973). A variedade "Burr White" após ser submetida a 70 gerações de seleção divergente para teor de óleo e proteina, continuou mostrando a existéncia de variabilidade genética significativa.

No Brasil, o esquema de seleção entre e dentro de familias de meios irmãos vem sendo utilizado hà alguns anos, principalmente, no Instituto de Genética da Escola Superior de Agricultura "Luiz de Queiroz" (ESALQ). Um re sumo das estimativas obtidas para parāmetros genéticos e fenotípicos, em diferentes populações de milho da ESALQ, foi apresentado por RAMALHo (1977). Neste levantamento, verificou se uma estimativa média da variância genética aditiva $\left(\hat{\sigma}_{A}^{2}\right)$ no va lor de $320(\mathrm{~g} / \mathrm{pl})^{2}$, para o caráter produção de grãos. os va lores médios encontrados para o coeficiente de herdabilidade 
.9 .

$\left(\widehat{h}^{2}\right)$, para o coeficiente de variação genética $\left(\mathrm{CV}_{\mathrm{g}}\right)$ e para o indice de variação $\theta$, foram $9,67 \%, 8,21 \%$ e 0,454 , respectivamente.

As estimativas mais a 1 tas e mais baixas para

$\hat{\sigma}_{\mathrm{A}}^{2} 758(\mathrm{~g} / \mathrm{p} 1)^{2}$ e $41(\mathrm{~g} / \mathrm{p} 1)^{2}$ e para o indice de variação $\theta(0,84$ e 0,25) foram encontradas, respectivamente, por PATERNIANI (1968) e ZINSLY (1969). Por outro 1ado, PATERNIANI (1967 e 1968 ) mostrou o maior e o menor valor obtido para o $\mathrm{CV}_{\mathrm{g}}$ $(15,31 \%$ e $3,37 \%)$, enquanto que a estimativa mais elevada para $\widehat{h}^{2}(28,45 \%)$ foi apresentada por PATERNIANI (1968), e a me nor (2,09\%) foi encontrada por TORRES SEgOVIA (1976).

Resultados promissores foram também evidencia dos por LIMA (1977), que utilizou familias de meios irmãos derivadas do Composto VD-2, observando que as estimativas pa $\mathrm{ra}$ as $\hat{\sigma}_{\mathrm{A}}^{2}\left[438,83(\mathrm{~g} / \mathrm{pl})^{2} ; 377,81(\mathrm{~g} / \mathrm{pl})^{2}\right.$ e $\left.344,32(\mathrm{~g} / \mathrm{pl})^{2}\right]$ não decresceram significativamente após dois ciclos de seleção,sen do detectado um progresso médio esperado por ciclo no valor de $8,15 \%$, o qual foi inferior a o progresso observado em rela ção às testemunhas $(10,8 \%)$. As estimativas obtidas para os coeficientes de herdabilidade ao nivel de plantas individuais foram $8,10 \%, 12,23 \%$ e $18,64 \%$, e para os coeficientes de variação genética foram $7,35 \%, 7,21 \%$ e $6,26 \%$, correspon dentes, respectivamente, aos ciclos original, I e II.

MIRANDA FILHO (1974) mostrou a potencialidade de sete populações para a formação do Composto ESALQ-PB1, e posteriormente (MIRANDA FILHO, 1977 e 1979) efetuou avalia ções com familias de meios irmãos, mostrando estimativas bas tante semelhantes para a avaliação de dois ciclos de seleção, chegando à conclusão de que haveria éxito em se obter uma população bastante melhorada, haja vista a variabilidade genética aditiva existente para todos os caracteres estudados. 
Por outro lado, SOUZA JUNIOR (1983) avaliou progēnies de meios irmãos provenientes da recombinação de 100 familias $S_{1}$, selecionadas após o primeiro ciclo de seleção da população ESALQ-PBl, encontrando uma estimativa para a $\sigma_{A}^{2}$ intermediária $263,2449(\mathrm{~g} / \mathrm{p} 1)^{2}$ entre os dois ciclos de avaliação efetuados por MIRANDA FILHO (1977 e 1979), e estimativas um pouco mais altas para $\hbar^{2}(10,55 \%), \mathrm{CV}_{\mathrm{g}}(6,88 \%)$, indice de variação $\theta(0,48)$ e progresso esperado com ouso de sementes remanescentes $(9,21 \%)$.

Resultados de diversos trabalhos, referentes a dez diferentes populações, demonstraram a presença de variabilidade genética capaz de se conseguir progressos com a seleção. As estimativas obtidas para as variāncias genéticas aditivas, conforme relataram GERALDI (1977), CRISóstomo (1978), RISSI (1980), SAWAZAKI (1979), SOUZA JUNIOR et alii (1980) e AGUILAR MORAN (1984), variaram de $87,720(\mathrm{~g} / \mathrm{pl})^{2}$ à $626,04(\mathrm{~g} / \mathrm{p} 1)^{2}$, e para os coeficientes de herdabilidade osci 1 aram de $2,2 \%$ a $28,95 \%$. Os valores estimados para os coeficientes de variação genética situaram-se numa faixa de $5,5 \%$ à $9,24 \%$, enquanto que os indices de variação $\theta$ apresentaram uma am plitude de 0,37 a 0,88 . Apesar de algumas estimativas obtidas para os coeficientes de herdabilidade terem sido baixas, a média estava ao redor de $7,5 \%$, e os autores acima menciona dos consideraram as populações como potencialmente promissoras, tendo em vista a quantidade de variabilidade genética que foi exibida, e que poderá ser explorada na continuidade dos programas de melhoramento.

\subsubsection{Caracteres da planta}

No Brasil, o melhoramento de milho tem sido dirigido, principalmente, para a alta produtividade (MIRANDA 
FILHO, 1974) e pouca ênfase tem sido dada a outros caracteres, tais como, altura da planta e espiga, razão pela qual as populações existentes exibem crescimento elevado, deixando muito a desejar no que diz respeito à arquitetura da plan ta (BARRIGA BEZANILLA, 1971). Mais recentemente, porém, diversos programas de pesquisa têm incluido em suas metas a ob tenção de cultivares com arquiteturas mais adequadas.

No que diz respeito aos atributos agronómicos de altura da planta e espiga, estudos, observações e impor täncia dos mesmos têm sido relatados hä muito tempo, relacio nando-os, principalmente, com os resultados da seleção.

Os trabalhos de Smith (1909) e Kiesselbach (1922), citados por ACOSTA e CRANE (1972), mostraram haver variabilidade genética para obter populações contrastantes quanto à altura da planta e da espiga. Do mesmo modo, os efeitos reais ou potenciais da seleção para estes caracte res são explicitos nos trabalhos de PATERNIANI (1967), VERA e CRANE (1970), ACOSTA e CRANE (1972), MIRANDA (1978), GHINI e MIRANDA FILHO (1979) e SOUZA JUNIOR (1983), para diminuição destes caracteres em diferentes populações de milho.

Segundo MIRANDA FILHO (1974), estes caracteres podem ser alterados geneticamente de duas maneiras diferentes: a) atravēs do poligenes e, b) através de genes maiores. Há, de úm modo geral, a preocupação em reduzir a a 1tura da planta e da espiga, uma vez que elas estão relacio nadas com o acamamento ou quebramento do côlmo, colheita, bem como para a obtenção de ideotipos.

Os estudos sobre componentes de variação genę tica efetuados por GARDNER et alii (1953), ROBINSON et ali 
(1955) e HALlaUeR (1971), mostraram que estes caracteres são controlados predominantemente por genes com efeitos aditivos e com domināncia parcial (COMSTOCK e ROBINSON, 1948; ROBIN SON et alii, 1951).

Recentemente, HALlAUER e MIRANDA FILHO (1981) realizaram um extenso levantamento das estimativas das variāncias genéticas para estes caracteres, mostrando que a maior proporção da variāncia genética total pode ser atribuida aos efeitos aditivos. As estimativas médias da variân cia aditiva, obtidas de 45 e 52 trabalhos, respectivamente, para altura da planta e espiga, foram $219,90(\mathrm{~cm} / \mathrm{p} 1)^{2}$ e $152,70(\mathrm{~cm} / \mathrm{pl})^{2}$, enquanto que os valores médios para o coefi ciente de herdabilidade ao nivel de parcelas foram $56,9 \%$ e $66,2 \%$.

Dentre os inümeros resultados de estimativas de componentes de variação genética encontrados na literatura, alguns são mostrados na Tabela 1. Verificou-se que as estimativas para as variâncias genéticas aditivas $\left(\hat{\sigma}_{A}^{2}\right)$ para a ltura da planta situaram-se entre 63,0 (cm/p1) ${ }^{2}$ e 641,548 $(\mathrm{cm} / \mathrm{p} 1)^{2}$, enquanto que as $\hat{\sigma}_{\mathrm{A}}^{2}$ para a 1 tura de espiga estavam compreendidas entre $86,80(\mathrm{~cm} / \mathrm{pl})^{2}$ e $483,753(\mathrm{~cm} / \mathrm{pl})^{2}$.

Resultados mais consistentes e informativos foram obtidos com diversas populações de milho no Brasil, através de estimativas obtidas nos programas de selecão entre e dentro de familias de meios irmãos, conforme podem ser vistos na Tabela 2. As estimativas encontradas para a variāncia aditiva, referentes, respectivamente, à altura da planta e espiga, estiveram numa amplitude de 176,56 a 668,00 e 46,136 a 548,00 , expressas em $(\mathrm{cm} / \mathrm{p} 1)^{2}$. 
.13.

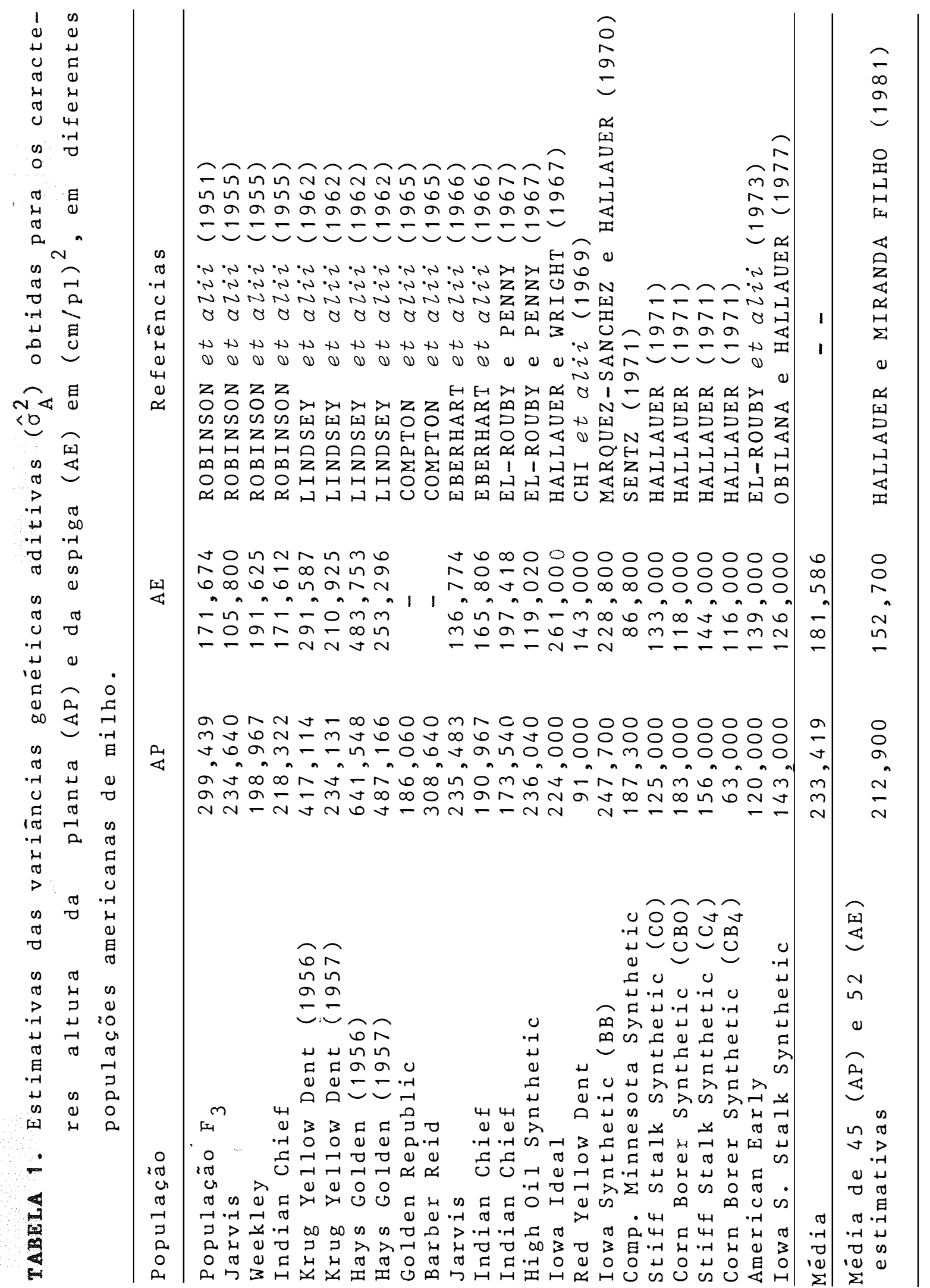




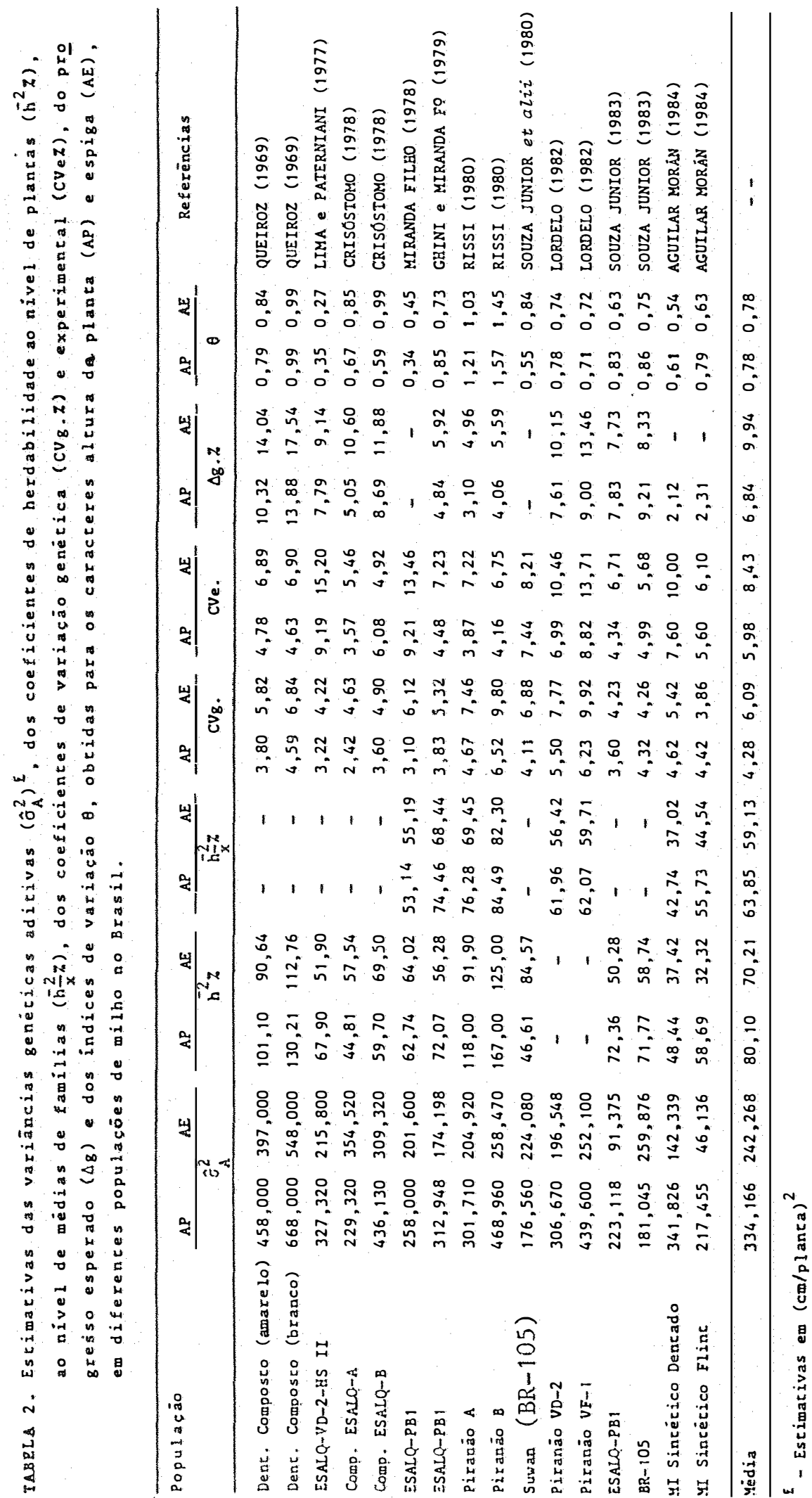


para os coeficientes de herdabilidade quanto as estimativas obtidas para os coeficientes de variação genética e indices de variação $\theta$, foram altas.

Estes resultados constituem-se em fortes indi cadores para o sucesso da seleção, uma vez que foi constatada a presença de variabilidade genética nas populações brasi leiras, superior, para ambos os caracteres, às populaçóes americanas .

Um outro caráter relacionado à arquitetura e eficiēncia da planta de milho, e que tem merecido a atenção de melhoristas, é o tamanho de inflorescēncia mascuIina (pendão): Desde o final do século passado, já era do conhecimento que a inflorescencia masculina do milho exercia a lguma influēncia na produção (GERALDI, 1977); no entanto, foi somente com o advento do milho hibrido que o interesse para este carảter foi despertado.

Tem sido mostrado que, tanto o despendoamento quanto plantas macho-estéreis conduzem a um aumento na produ ção de grãos em condições ambientais favoräveis (LEONARD e KIESSELBACH, 1932; HUNTER et a iii, 1973) e condições adversas (DUNCAN et ali $i, 1967$; HUNTER et ali $i$, 1969). Estudos adicionais evidenciaram que pendões menores são benéficos pa ra maiores produções, especialmente em ambientes menos favorảveis, tais como, deficiēncia de umidade, maior densidade populacional e baixa fertilidade dos solos (BUREN et a $i$ i , 1974 ; MOCK e SCHUETZ, 1974).

$\mathrm{Na}$ certeza de que o passo inicial para o melhoramento genético de um caráter é o estudo da base genética e a determinação da variabilidade existente na população, MOCK e SCHUETZ (1974) estudaram a herança do nümero de ramificações do pendão e obtiveram estimativas para os componen- 
tes de variação genética. Constataram que este caráter tem herança quantitativa, e que a variāncia genética aditiva foi mais importante que a dominante. O coeficiente de herdabilidade estimado ao nivel de plantas individuais $\left(\kappa^{2}\right)$ foi de $53 \%$ e ao nivel de médias de familias ( $\frac{2}{x}$ ) foi de $89 \%$, indicando que resultados promissores podem ser conseguidos, mesmo com o uso de métodos relativamente simples.

0 interesse em se estudar o nümero de ramificações do pendão, para melhorar a eficiēncia produtiva do mi 1ho, está se intensificando no Brasil, e alguns trabalhos jä evidenciaram resultados animadores.

A Tabela 3 mostra um resumo dos trabalhos efe tuados, podendo-se verificar que as estimativas obtidas para as variäncias genéticas aditivas $\left(\hat{o}_{\mathrm{A}}^{2}\right)$ variaram de 6,5012 a $43,9648$ (ramificações/p1) $)^{2}$, enquanto que as estimativas para os $h^{2}$ estiveram compreendidas entre $30,7 \%$ e $67,48 \%$. Por outro 1 ado, os indices de variação $\theta$ e os coeficientes de variação genética foram altos, dando uma indicação da variação genética presente nas populações.

\subsubsection{Caracteres da espiga}

Os caracteres da espiga são em grande nümero e têm sido subdivididos em secções, para efeito de classificação de germoplasmas (BRIEGER et alii, 1958; PATERNIANI e GOODMAN, 1977), sendo, no entanto, considerados no presente estudo os caracteres mais relacionados com os componentes da produção: comprimento da espiga (CE), número de grãos por fileira (NGF), nümero de fileiras por espiga (NFE), diāmetro da espiga (DE), e diāmetro do sabugo (DS). 
.17.

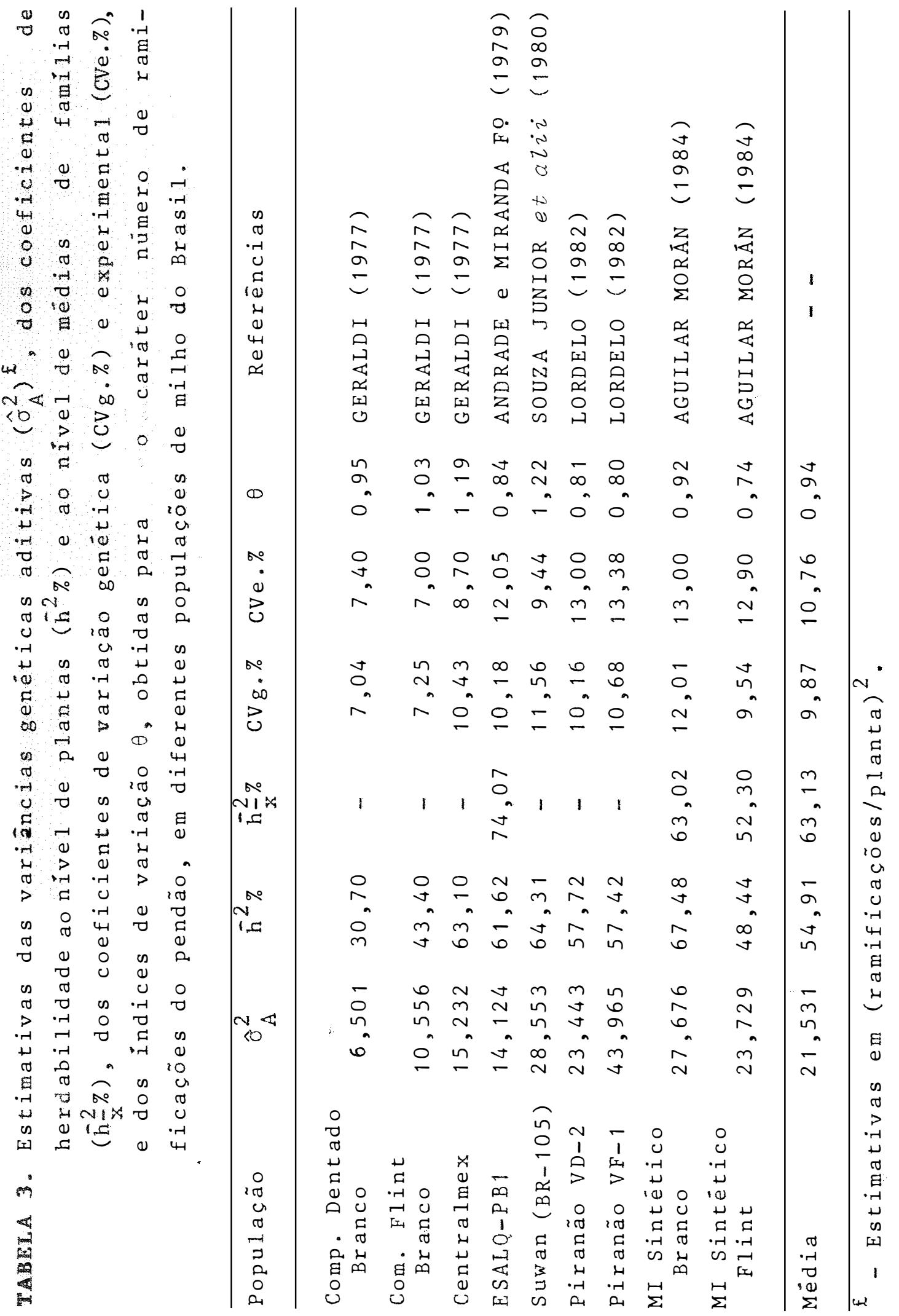


resse no milho, quando LENG (1953) considerou a produção como sendo manifestada em tērmos de quatro componentes primärios e dois secundärios. Posteriormente, GRAFIUS (1960) reconheceu os componentes primários e os definiu numa fórmula multiplicativa, argumentando que a produção no milho pode ser expressa como um produto dos diversos caracteres componentes.

MOLL et alii (1962) discutiram e discordaram em parte das suposições anteriores, formuladas por GRAFIUS (1960), afirmando que qualquer vantagem em estudar isoladamente os componentes da produção, baseado num modelo simples, é pequena e, provavelmente, menor ainda que as desvantagens devido ao acümulo de ërros e outras dificuldades na interpre tação conjunta de componentes multiplicativos.

A produção é um carāter complexo e representa o produto final da interrelação de inumeras variáveis, cu jos efeitos individuais não podem ser prontamente identificáa veis; è uma expressão combinada do genótipo e ambiente, do inicio ao final do periodo de crescimento (HALlauer e MIRANDA FILHO, 1981). Por esta razão, SMITH (1967), HALLAUER (1977), HALLAUER e MIRANDA FILHO (1981) acreditam que a avaliação da produção continuará a ser feita como antes, apesar dos esforços para decompor a produção em seus componentes, e estuda-1os sob o ponto de vista dos componentes de variação genëtica.

Desta forma, estudos sobre os componentes da variação genētica tém sido feitos com mais intensidade para a produção, uma vez que na função de produção a participação dos componentes produtivos "per se" é variável, devendo-se, porém, considerar no melhoramento, qual ou quais caracteres poder ser mais eficientemente melhorados para aumentar signi 
ficativamente o produto final (produção).

Os trabalhos básicos iniciais de ROBINSON et ali $i$ (1949), GARDNER et alii (1953), GARDNER e LONNQUIST (1959) evidenciaram suficiente variabilidade genética e mostraram estimativas menores que 1,0 para o grau médio de domināncia dos caracteres de espiga, indicando, em média, a presença de parcial à completa dominância.

A confirmação indireta, fornecida atravēs da relação $\hat{\sigma}_{D}^{2} / \hat{\sigma}_{A}^{2}$, foi dada por HALlaUer e MIRANDA Filho (1981), quando mostraram, por meio de um amplo levantamento efetuado e com diferentes populações de milho, que para todos os caracteres a variabilidade genética estä presente, e a maior porção desta variabilidade foi devido à variância genética aditiva.

Neste sentido, inümeros trabalhos têm sido de senvolvidos para averiguação da variabilidade genética aproveitàvel na seleção, para os componentes da produção.

A Tabela 4 mostra alguns resultados obtidos para comprimento de espiga (CE), referentes à estimativas da variância genética aditiva, em (cm/espiga) ${ }^{2}$, e do coeficiente de herdabilidade ao nivel de médias $\left(h \frac{2}{\%} \%\right)$, cujas amplitudes de variação foram de $90,00 \times 10^{-2}$ a $352,40 \times 10^{-2}$ e de $17,30 \%$ $\therefore 62,60 \%$, respectivamente. HALlAUER e MIRANDA FILHO (1981) encontraram, num total de 36 trabalhos, estimativas médias nos valores de $152,40 \times 10^{-2}$ e $38,10 \%$, respectivamente, para a variáncia genética aditiva e coeficiente de herdabilidade ao nivel de médias.

O resumo dos resultados encontrados para nüme ro de grãos por fileira (NGF) e nümero de fileiras por espiga (NFE) pode ser visto na Tabela 5 , sendo as estimativas 


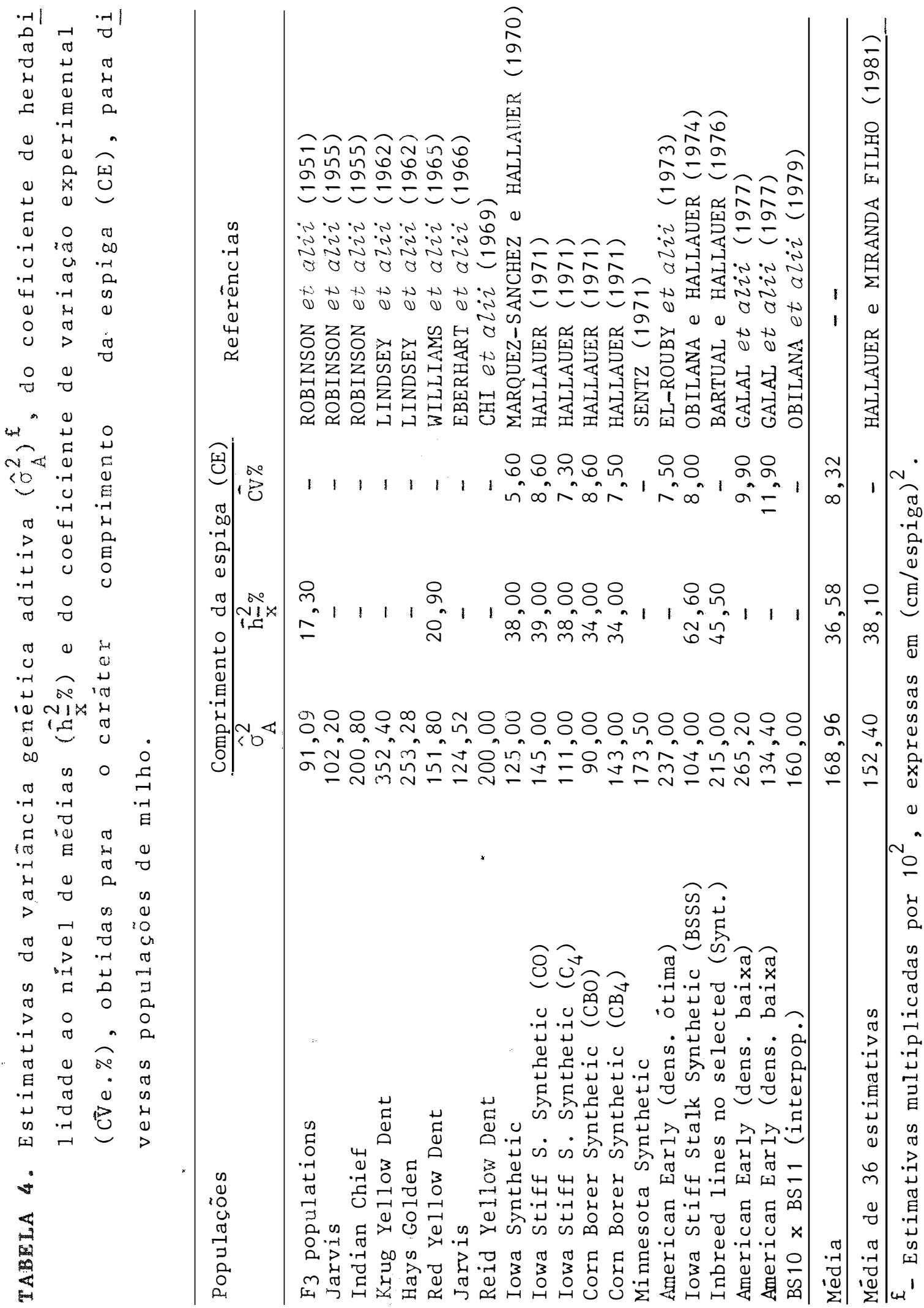


.21.

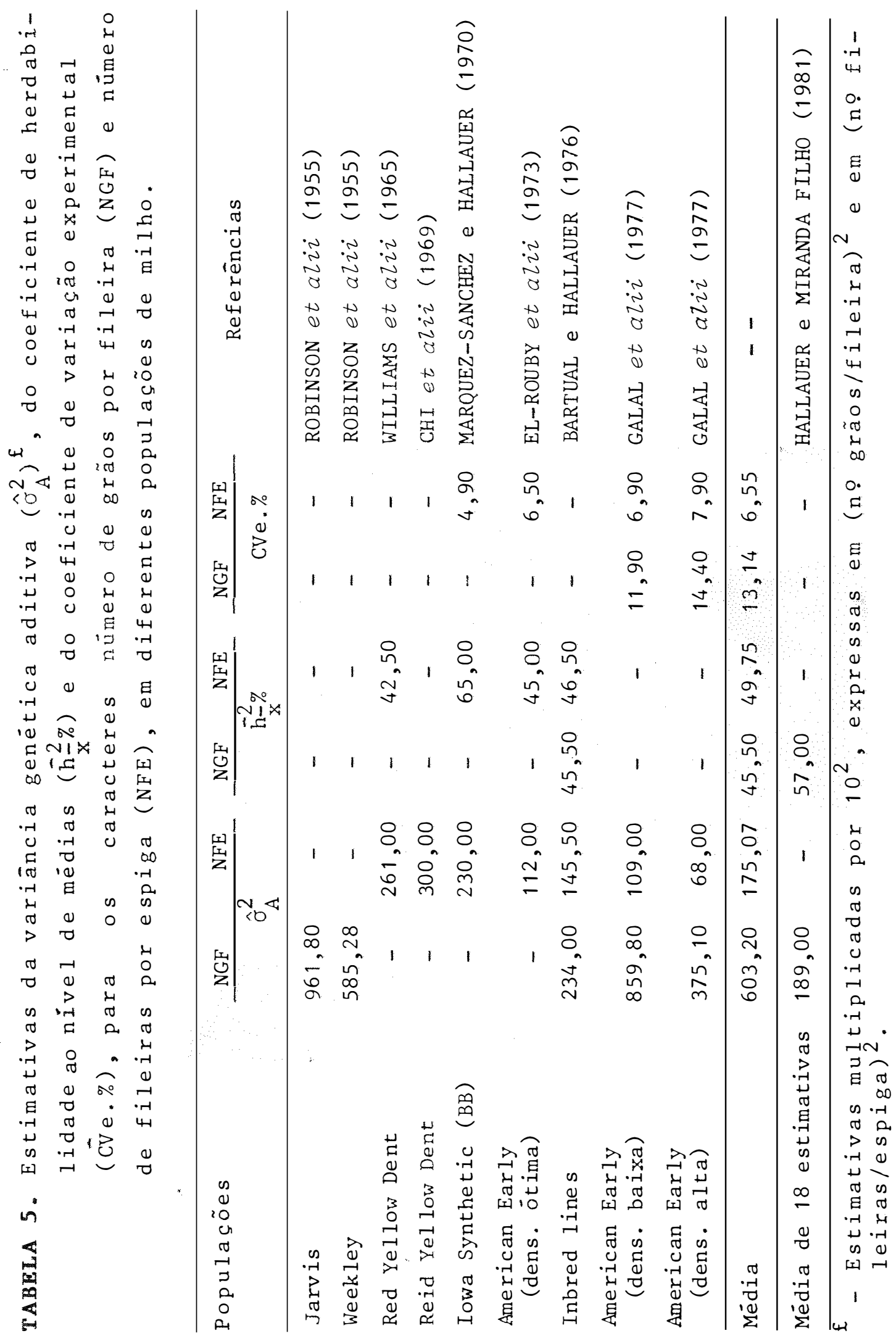


das variāncias genéticas aditivas $\left(\hat{O}_{A}^{2}\right)$ expressas, respectiva mente, em (nọ grãos/fileira) ${ }^{2}$ e (no folleiras/espiga) ${ }^{2}$. Nota -se que as estimativas obtidas para $\sigma_{A}^{2}$, estiveram numa $f a i x a$ de $234,00 \times 10^{-2}$ a $961,80 \times 10^{-2}$ e $68,00 \times 10^{-2}$ a $300,00 \times 10^{-2}$, res pectivamente, para NGF e NFE. As estimativas para $h \frac{2}{x}$ oscila ram de $42,50 \%$ a $65,00 \%$ para NFE, enquanto que a ünica estima tiva de $h \frac{2}{x}$ para NGF foi $45,50 \%$. - valor médio estimado de 18 trabalhos para
$\sigma_{A}^{2}$ e ${ }^{2}$, foi, respectivamente, 189,00 e $57,00 \%$, apenas para
o caräter NFE (HAllautr e MIRANDA FILHo, 1981).

Com referēncia aos caracteres diàmetro da espiga (DE) e diàmetro do sabugo (DS), a Tabela 6 evidencia os resultados obtidos por diversos autores, sendo as estimati vas das variâncias genéticas aditivas expressas, respectivamente, em (cm/espiga $)^{2}$ e $(c m / s a b u g o)^{2}$. Conforme pode ser visto, as estimativas obtidas para $\sigma_{\mathrm{A}}^{2}$ tiveram uma amplitude de variação entre $1,81 \times 10^{-2}$ a $12,00 \times 10^{-2}$ e $1,50 \times 10^{-3}$ a 38,00 $\times 10^{-3}$, respectivamente, para DE e DS. Por outro lado, as es timativas de $h \frac{2}{x}$ para DE oscilaram de $14,10 \%$ a $60,00 \%$, enqua to que para DS variaram de $37,00 \%$ e $75,00 \%$.

No levantamento realizado por HALLAUER e MI RANDA FILHO (1981), a estimativa média da $\sigma_{A}^{2}$ para DE foi de $4,60 \times 10^{-2}$ e $16,60 \times 10^{-3}$ para DS. As estimativas encontradas para os coeficientes de herdabilidade foram bastante similares $(36,10 \%$ e $37,00 \%)$, respectivamente, para diâmetro da espiga e diàmetro do sabugo.

No Brasil, raros foram os trabalhos desenvolvidos que englobassem estimativas dos componentes de variação genética para os caracteres acima mencionados, destacando-se apenas QUEIROZ (1969) que utilizou a população Dentado 


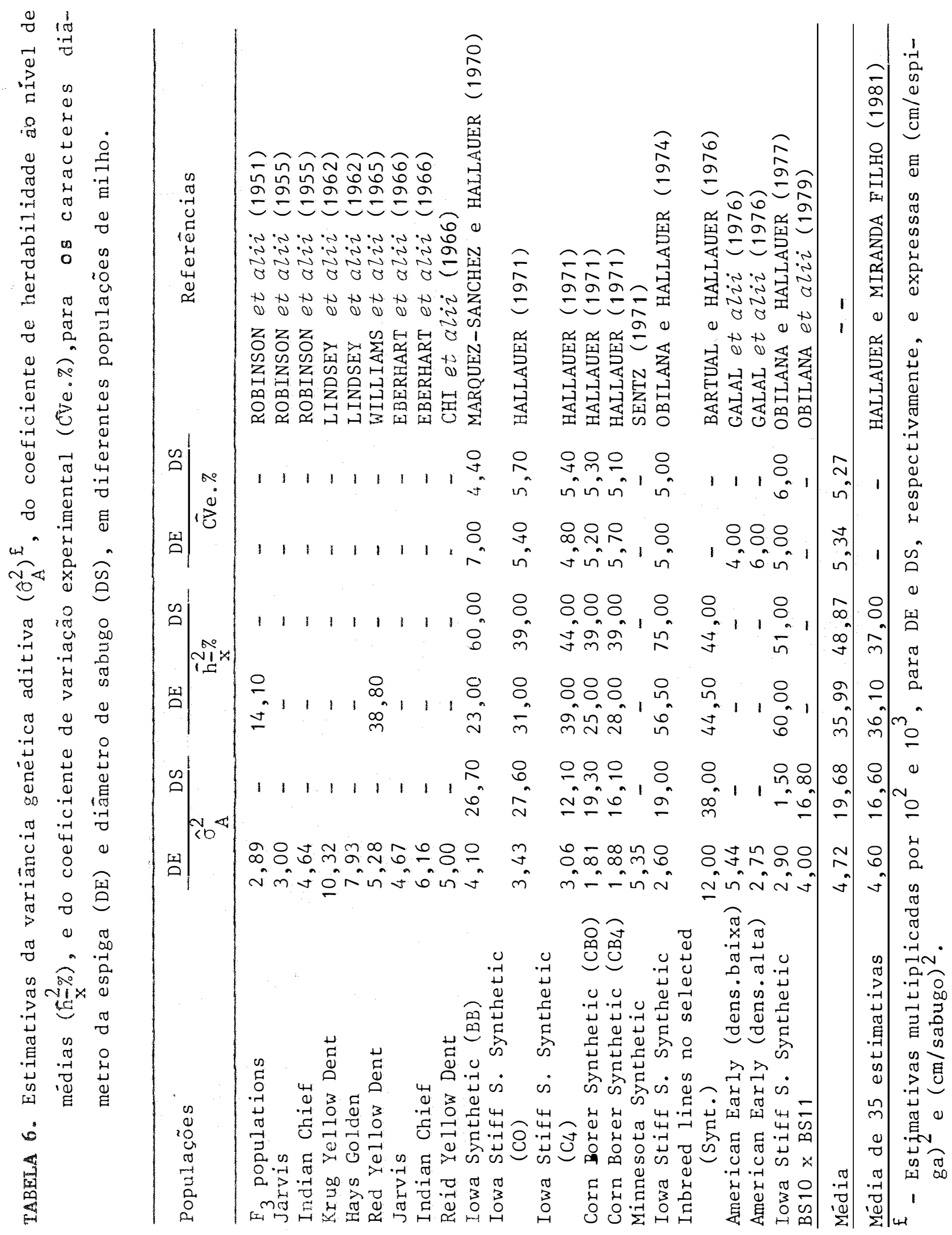


Composto de sementes amarelas e brancas, e MOTA (1974) que féz uso da população centralmex. As estimativas obtidas para os caracteres estudados situaram-se entre as amplitu des de variação mencionadas anteriormente, exceto para a variäncia genētica aditiva $\left(\hat{\sigma}_{A}^{2}\right)$ do nümero de grãos por fileira, conforme evidenciado por MOTA (1974).

\subsection{Germoplasmas exóticos}

\subsubsection{Potencial}

Germoplasma exótico pode ter as mais variadas conotações. A palavra exótico "per se" pode ter significados diferentes: estrangeiro, estranho, não nativo, introduzi do de outro lugar, esquisito etc..

Na opinião de LONNQUIST (1974), milho exótico foi definido como sendo oriundo de outra àrea, estando repre sentado por adaptações diferentes à altitudes, latitudes, tí pos de solos, fatores ambientais etc.. HALlAUER (1978) considerou germoplasma exótico como todas as fontes de germoplasmas que não são imediatamente üteis ou adaptadas para um especifico programa de melhoramento. Para programas de melhoramento aplicado, o germoplasma exótico inclui todos os materiais que não têm utilidade imediata sem a seleção para uma determinada ärea (HALlaUer e MIRANDA FILHO, 1981).

Dentro desta ampla diversificação de significados os germoplasmas exóticos podem ser constituidos por ra ças, populações, linhagens etc., desde que quando crescidos em ăreas diferentes dos seus locais de adaptaçãonão manifes tem suas potencialidades sem um ajuste fisiológico. 
bilidade no milho, a morfologia e nümero dos seus cromossomos è uniforme entre as diversas raças, populações e 1 inhagens (GALINAT, 1977), permitindo que amplos cruzamentos sejam efetuados entre os exöticos e adaptados. No entanto, os efeitos imediatos destes cruzamentos têm sido frequentemente desapontadores, uma vez que para produtividade os segregantes desejáveis foram 1 imitados, sendo os materiais descartados como não promissores.

Para se obter combinações de genes que tenham funções bioquimicas eficientes dentro do genoma, è necessário permitir uma adequada recombinação da população resultan te do cruzamento (HALlaUer e MIRANDA FILHO, 1981). Isto foi mostrado por HANSON (1959), onde salientou que a principal quebra dos blocos de ligação ocorre entre a quarta e quinta geração de intercruzamento ao acaso.

A importância e o potencial de germoplasmas exóticos de milho, para inclusão em programas de melhoramento, já foram amplamente enfatizadas por inümeros pesquisadores (BROWN, 1953 e 1975; GRIFFING e LINDSTROM, 1954; WELLHAU SEN, 1956 e 1965; PATERNIANI, 1962; BRIEGER, 1963; BENNET, 1970 ; ZOHARY, 1973 ; LONNQUIST, 1974; ZUBER, 1975 ; BROWN e GOODMAN, 1977; ZUBER e DARRAH, 1980; DUVICK, 1981, entre outros). Recomendações têm também sido feitas para proporcionar as recombinações minimas necessärias para quebra dos blo cos de 1 igação, a fim de que ocorram os segregantes potencia 1mente aproveitáveis (WELLHAUSEN, 1965; LONNQUIST, 1974 ; SHEATA e DRAWN, 1975, entre outros). Do mesmo modo, tem sido enfatizada a importāncia do tamanho efetivo populacional nos processos de introdução e recombinação de populações segregantes (MIRANDA FILHO e VENCOVSKY, 1979 ; HALLAUER e MIRAN DA FILHO, 1981). 
tuaram as primeiras indagações sobre o potencial de germoplasma exótico que deveria ser incorporado nas 1 inhagens de milho do Corn Belt. Concluiram que a introgressão do germoplasma exótico foi benéfica tanto para aumento da produção do hibrido quanto para o aumento da diversidade genética. Por outro lado, BRIEGER et ali $i$ (1958) e BRIEGER (1963) descreveram coleções de milhos indigenas e mostraram algumas ra ças com bons caracteres que poderiam ser aproveitados em programas de melhoramento.

A potencialidade de incorporar germoplasmas exóticos em linhagens adaptadas, para posterior desenvolvi mento de milhos hibridos, foi mostrada por GRIFFING e LINDSTROM (1954), EFRON e EVERETT (1969) e NELSON (1972), enquanto que KRAMER e ULLSTRUP (1959) mostraram o beneficio da introgressão de genes exóticos como fontes de resistência à doenças, e THOMPSON (1968) destacou a importāncia dos germoplasmas exóticos para a produção de silagem.

Evidéncias de resultados positivos da introgressão de genes exóticos em populações jả adaptadas foram mostradas por TIMOTHY (1965) e WELLHAUSEN (1965), os quais recomendaram maior atenção por parte dos melhoristas, tendo em vista as potencialidades dos germoplasmas exóticos. No en tanto, a partir da década de 70 é que houve um despertar para o problema da vulnerabilidade genética do milho, haja vis ta a catástrofe que devastou parte de sua produção mundial, em decorrência do acentuado estreitamento da base gené tica, apesar da extensa variabilidade existente e disponível para os melhoristas nas coleções mundiais (HARLAN, 1961; JEN SEN, 1962; WHITE, 1963; ALLARD, 1970).

A descrição de peculiaridades morfológicas e fisiológicas entre diversificados tipos de milho foi, prime ramente, feita por KULESHOV (1928 e 1933), onde mostrou a 
grande variabilidade existente para värios caracteres, e em diferentes regiões do mundo.

Atualmente, o grande nümero de coleções existentes, no Novo Mundo e na Europa, é uma prova da inesgotável riqueza genética que estả a disposição dos melhoristas, conforme pode ser visto na Tabela 7 (HALLAUER e MIRANDA FILHO, 1981, pg. 384). Inümeras raças têm sido descritas e apontadas como potencialmente úteis para incorporação de genes em populações jà adaptadas ou para o melhoramento "per se", bastando somente escolher acertadamente o germoplasma exötico com os caracteres desejados (WELlHAUSEN, 1965; BROWN e GOODMAN, 1977; GOODMAN e PATERNIANI, 1977; HALLAUER e MIRANDA FILHO, 1981 , entre outros).

PATERNIANI e GOODMAN (1977) relataram que, para as 250 raças descritas para o Novo Mundo, 50\% são adaptadas à baixas altitudes $(0$ a $1.000 \mathrm{~m}), 40 \%$ são crescidas em altitudes maiores que $2.000 \mathrm{~m}$, e $10 \%$ são adaptadas para alti tudes intermediärias $(1.000$ a $2.000 \mathrm{~m})$. Considerando o tipo de endosperma, salientaram que quase $40 \%$ são farināceas, qua se $30 \%$ säo flints, um pouco mais de $20 \%$ são dentadas, cerca de $10 \%$ são do tipo pipoca, e os $3 \%$ restantes pertencem ao grupo dos milhos doces.

Nos Estados Unidos, ZUBER (1975 e 1980) afirmou que o estreitamento da base genética é decorrente do uso de poucas linhagens para a formação dos híbridos, apesar das populações base serem de origens diferentes. A partir de 1970 é que houve um crescente interesse em aumentar a base genética dos materiais, tanto por parte dos órgãos püblicos quanto pelas empresas privadas.

Em um levantamento efetuado por DUVICK (1981), foi constatado que a diversidade dos pools gênicos aumentou 
TABELA 7. Distribuição das coleções existentes e das raças de milho descritas para o México, América Central, América do Sul, Europa e Estados Unidos (Hallauer e MIRANDA FILHO, 1981, pg. 384).

\begin{tabular}{|c|c|c|c|}
\hline Fonte & Pais & $\begin{array}{c}\text { Nọ d e } \\
\text { oleções }\end{array}$ & $\begin{array}{l}\text { No de } \\
\text { raças }\end{array}$ \\
\hline WELLHAUSEN et ali $i$ (1952) & México & 2.000 & 32 \\
\hline HATHAWAY ( 1957$)$ & Cuba & - & 7 \\
\hline ROBERTS et a $i i i$ (1957) & Colömbia & 1.999 & 23 \\
\hline WELLHAUSEN et ali $i$ (1957) & A. Centra 1 & 1.231 & 13 \\
\hline BRIEGER et alii (1958) & Brasil & 3.000 & 52 \\
\hline PATERNIANI e GOODMAN (1977) & Brasil & 3.000 & 52 \\
\hline RAMIREZ et alii (1960) & Bolivia & 844 & 32 \\
\hline BROWN (1960) & Indias Ocident. & 135 & 7 \\
\hline TIMOTHY et alii (1961) & Chile & $39-114$ & 19 \\
\hline GROBMAN et alii (1961) & Peru & 1.600 & 49 \\
\hline GRANT et arii (1963) & Venezue 1 a & 685 & 19 \\
\hline TIMOTHY et alii (1963) & Equador & 675 & 23 \\
\hline BRANDOLINI (1969) & Europa & 6.000 & 11 \\
\hline BROWN e GOODMAN (1977) & Estados Unidos & - & 9 \\
\hline
\end{tabular}


$77 \%$ em relação a 1970 , sendo a maior parte conseguida atra vës de cruzamentos com germoplasmas exóticos. Comentou ainda que, apesar da quase metade das entidades püblicas e privadas responderem que a vulnerabilidade genética não se cons tituia em um problema hoje, a maioria delas tem programas de melhoramento objetivando aumentar a diversidade genética de suas populações base ou 1 inhagens. Concluiu que houve um re conhecimento do potencial e necessidade de incorporação de germoplasmas exóticos dentro das populações já adaptadas, quer seja para prevenção de nova catảstrofe ou para aumentar a produtividade da cultura.

Especificamente, no Brasil, os programas de melhoramento de milho começaram a ser intensificados a par tir de 1952 com a formação do Banco de Germoplasma (BRIEGER et $a$ Zi, 1958 ; PATERNIANI, 1963).

A coleta de milho realizada no Brasil e em paises vizinhos, bem como a introdução de germoplasmas do Mé xico, possibilitaram um estudo e avaliação dos materiais dis poniveis para a formação de novas populações. PATERNIANI et alii (1977) descreveram o modo de obtenção de 21 populações melhoradas e suas respectivas caracteristicas, indicando cla ramente os germoplasmas exóticos que tomaram parte na formação destas populações, e destacando a utilização das mesmas em programas de melhoramento de instituições privadas ou of ciais, bem como sua distribuicão à agricultores e produtores de sementes.

MIRANDA FILHO (1974) refere-se à utilização de populações introduzidas do México, Colómbia e Argentina para a sintese de compostos de milho com ènfase especial para o porte da planta; a avaliação de tais materiais em cruza mentos dialélicos é relatada por MIRANDA FILHO e VENCOVSKY (1984). MIRANDA FILHO e VENCOVSKY (1979) referem-se também 
à introdução de germoplasmas exöticos, incluindo os de origem de clima temperado. LIMA et alii (1982) relataram resu1 tados da avaliação de germoplasmas exóticos com vistas à introdução de resistência para a doença conhecida por "downy mildew" (Peronosclerospora sorghi). Do mesmo modo, uma ampla introdução de germoplasmas do México (CIMMYT) è relatada por MORO et alii (1981).

Em outras culturas, a literatura mostra também a potencialidade dos germoplasmas exóticos. PETERSON (1975) relatou que a obtenção de resistência para doenças do melão, pepino, alface e abóboras foi conseguida através da utilização de germoplasmas exóticos. Resultados promissores para produção foram também obtidos por MARANI (1967) em algo dão, STEPHENS et alii (1967) e MALMM (1968) em sorgo, THORNE e FEHR (1970), SCHOENER e FEHR (1979) e VELLO et alii (1984) em soja, LAURENCE e FREY (1975) em aveia, BLISS (1981) em feijão e tomate, onde evidenciaram amplas possibilidades de obterem populações adaptadas e mais produtivas através da in corporação de germoplasmas exóticos nos materiais jả adaptados, bastando tão somente, tempo e paciência para identifica ção e estabelecimento dos segregantes transgressivos comercialmente viàveis.

\subsubsection{Metodologias e resultados obtidos}

Inegavelmente, a performance geral das popula cões, linhagens, variedades etc., em uso atual, é bastante superior à dos germoplasmas exóticos. Se a seleção direta fosse realizada nos "pools" gênicos exóticos, muito tempo se ria requerido para atingir os niveis das cultivares utiliza das no momento, não aumentando também a variabilidade das po pulações jà adaptadas e identificadas geneticamente como potenciais para o melhoramento. 
Desta maneira, o procedimento mais comum para estudos de germoplasmas exóticos tem sido cruzamentos entre exóticos $x$ adaptados (HALLAUER, 1978), com o objetivo de detectar a heterose nas populaçōes resultantes dos cruzamentos (semi-exóticas), de quantificar os efeitos da incorporação para os caracteres desejados através da seleção massal, e muito raramente para estimação dos componentes de variação genëtica das populações semi-exóticas, a fim de comparar a variabilidade genética em relação à população originalmente adaptada e melhorada.

Muito embora a importância e o potencial dos germoplasmas exóticos de milho jà tenham sido reconhecidos, a quantidade de informações sobre o uso destes materiais é bastante limitada na literatura. Sobre este aspecto, HALLAUER e MIRANDA FILHO (1981) comentaram que os poucos resultados encontrados são, geralmente, positivos, e mesmo assim podem estar confundidos, como uma indicação do esforço que foi gasto em escolher e avaliar os germoplasmas exóticos. A creditam que, muito provavelmente, a inclusão de exóticos tem sido feita na maioria dos programas de melhoramento,mas, os resultados ou foram negativos ou não relatados.

Os primeiros resultados de cruzamentos envolvendo diferentes raças foram mostrados por PATERNIANI e LONN QUIST (1963) e WELLHAUSEN (1965), onde observaram heteroses altas e indicaram, respectivamente, as raças potencialmente uteis para programas de melhoramento no Brasil e as raças que poderiam ser incorporadas nas linhagens do Corn Belt.

Valores significativos da heterose foram tambëm encontrados por MOLL et azi (1962), EBERHART (1971), SHEHATA e DRAWN (1975), HALLAUER e MALITHANO (1976) e GERRISH (1983), nos cruzamentos dialélicos realizados, onde to- 
maram parte diversos germoplasmas exóticos. Todas estas eví dências serviram de base para os autores recomendarem a incorporação de germoplasmas exóticos nos programas de melhora mento. Um bom exemplo foi fornecido por EBERHART (1971), ob tendo 5 populações derivadas dos cruzamentos de germoplasmas exóticos $x$ adaptados, as quaís se igualaram ou se excederam em produção, em relação às variedades adaptadas. Para isto, duas décadas foram necessārias para os cruzamentos, recombinações e seleções, resultando nestas populações semi-exóticas potencialmente üteis, alëm da adicional diversidade genética.

Programas de melhoramento populacional conduzidos com germoplasmas exóticos e semi-exóticos, comumente, tèm sido eficientes, apesar das limitadas vezes que tēm sido relatados. Nestes casos, a seleção massal tem provado ser eficiente para adaptabilidade e, algumas vezes, para produti vidade.

WELLHAUSEN (1965) comparou os efeitos da sele ção massal em um Composto formado por raças versus uma população exótica que participou para a formação do Composto. A pós o terceiro ciclo de seleção, verificou uma superioridade produtiva bem mais acentuada no Composto do que na população exótica, sugerindo, então, a formação de novos Compostos para aproveitamento da larga variabilidade.

Resultados animadores, com populações semi-exóticas e obtidos através da seleção massal, foram tambẻm descritos para redução da altura da planta (VERA e CRANE, 1970; HALLAUER e SEARS, 1972), e para redução no nümero de dias para florescimento (HALLAUER e SEARS, 1972; TROYER e BROWN, 1972), onde comprovaram herdabilidades altas para mudanças de caracteres associados à adaptabilidade. 
Tem-se verificado também, respostas das popu1 ações exóticas e semi-exóticas para aumento da produção. Se gundo GENTER (1976), além do aumento da produção em $171 \%$, pa ra um Composto formado a partir de 25 raças e submetido a dez ciclos de seleção massal, houve também uma redução na a 1 tura da planta e espiga. Resultados similares foram encontrados por COMPTON et a $2 i i$ (1979) e HANSON e JOHNSON (1981), os quais constataram um maior potencial de seleção para produção nos exóticos e semi-exóticos do que nas populações adaptadas.

Atẻ hoje, uma questão que tem permanecido em aberto é o percentual do germoplasma exótico que deverà ser incorporado nas populaçöes jā adaptadas, para a determinação de respostas mais eficientes.

GRIFFING e LINDSTROM (1954) trabalhando com linhagens americanas de milho que continham $100 \%, 50 \%$ e $25 \%$ de genes introduzidos de exóticos e com linhagens totalmente adaptadas, concluiram que os hibridos $F_{1}$ mais produtivos foram aqueles em que houve a participação de 1 inhagens com $50 \%$ e $25 \%$ de exóticos em cruzamentos com as adaptadas. Por outro 1 ado, WellhaUSEN (1965) recomendou incorporar dosagens menores ou iguais a $25 \%$ dos germoplasmas exóticos dentro dos germoplasmas adaptados do Corn Belt.

Objetivando determinar qual o efeito da incor poração de diferentes proporções de germoplasma exótico dentro de materiais adaptados para melhoramento da produção, HALLAUER (1978) conduziu quatro programas de seleção recorrente, mostrando as taxas de progresso esperado e o comporta mento da variabilidade genética. As proporções relativas dos germoplasmas exóticos.foram 100\%, $50 \%, 25 \%$ e $0 \%$, para as populasões BS 16, BS 2, BSTL e para a variedade de poliniza- 
ção aberta krug, respectivamente. Os resultados dos dois anos de ensaios de avaliação com progênies $S_{2}$, mostraram que a variància genética e o progresso esperado, dentro de cada ano, foram maiores para as populações semi-exóticas que para a população adaptada. No entanto, o autor comentou que houve a falta de um aumento bem significativo da variabilidade nas populações que incluiram germoplasma exótico, o que pare ceu ser não encorajador. Verificando, porém, as produçóes mëdias e o progresso esperado, constatou que a performance dos genótipos selecionados dos germoplasmas exóticos ou semi - exóticos foi superior ou comparável àquelas dos germoplasmas adaptados.

Deste modo, HALLAUER e MIRANDA FILHO (1981) comentaram que comparaçes criticas só poderão ser feitas após estudos adicionais, uma vez que os resultados prelimina res disponiveis não foram suficientes para determinar diferenças marcantes quanto ao percentual do germoplasma exótico que deverá ser incorporado nas populaçóes adaptadas.

Mais restritos ainda são os trabalhos disponi veis na literatura, para os caracteres da planta, espiga e para produção, que incluem estimativas e comparaçoes dos com ponentes de variação genética entre populações exóticas ou semi-exóticas versus populações adaptadas, e que forneçam me todologias e resultados que sirvam de subsidios consistentes para futuros estudos.

GOODMAN (1965) obteve estimativas da variabilidade genética para uma população de germoplasma adaptado (Corn Belt. Composite - CBC) e para uma população semi-exótica (West Indian Composite - WIC). Utilizou o Delineamento I, e as familias de meios irmãos e irmãos germanos foram ava 1 iadas em duas localidades, a fim de comparar as estimativas 
de variabilidade genética e progresso esperado. As estimati vas médias da variāncia genética aditiva $\left(\hat{\partial}_{\mathrm{A}}^{2}\right)$ para produção foram bem maiores na semi-exótica WIC $1.834,43\left(\mathrm{~g} / \mathrm{pl}{ }^{2}\right)$ do que na população adaptada CBC 783,24 (g/pl $\left.{ }^{2}\right)$. Para altura da planta e da espiga, as estimativas médias de o ${ }^{2}$ foram, respectivamente, $350,32(\mathrm{~cm} / \mathrm{pl})^{2}$ e $210,97(\mathrm{~cm} / \mathrm{pl})^{2} \mathrm{~A}$ na CBC, enquanto que para a WIC as $\hat{o}_{\mathrm{A}}^{2}$ foram $282,26(\mathrm{~cm} / \mathrm{p} 1)^{2}$ e 221,29 $(\mathrm{cm} / \mathrm{pl})^{2}$. os progressos médios esperados com a seleção massal foram $5,8 \%$ para a semi-exótica WIC, e $2,7 \%$ para a popula ção adaptada CBC.

Procurando determinar o efeito da incorporação de germoplasma exótico sobre a natureza e magnitude da variação genética em uma população de polinização aberta, SHAUMAN (1971) estudou as populaçes Krug (K) e Krug x Tabloncillo (KT) em duas densidades populacionais (baixa: $34.400 \mathrm{pl} / \mathrm{ha}$ e alta: $51.700 \mathrm{p} 1 / \mathrm{ha})$. Para peso de espigas na população $K$, as estimativas obtidas para a variāncia genética aditiva nas densidades baixa e alta foram 303,50 e 183,31 $(\mathrm{g} / \mathrm{p} 1)^{2}$, sendo que para KT estas estimativas foram 326,30 e $289,8(\mathrm{~g} / \mathrm{p} 1)^{2}$. Considerando o peso de grãos, as estimativas da variāncia genética aditiva para K foram 216,10 e 133,00 $(\mathrm{g} / \mathrm{pl})^{2}$, enquanto que para KT foram 300,80 e $233,40(\mathrm{~g} / \mathrm{pl})^{2}$, respectivamente para as densidades baixa e alta. Na população $K$ e em ambas as densidades populacionais, as estimativas encontradas para os coeficientes de variação genética estive ram ao redor de $5,5 \%$ para peso de espigas e de grãos, sendo que para a população $K T$ estas estimativas foram mais altas, principalmente na densidade populacional mais elevada, cujos valores obtidos foram 9,05\% e 10,05\%, respectivamente, para peso de espigas e de grãos. Com relação aos indices de variação $\theta$, a população $K$ apresentou valores semelhantes para peso de espigas e de grãos na densidade populacional baixa $(0,41)$ e na alta $(0,43)$. Na densidade populacional baixa, os Indices $\theta$ para a população KT foram 0,55 e 0,63, res 
pectivamente, para peso de espigas e peso de grãos, sendo que na densidade alta os valores obtidos para a população KT foram 0,53 e 0,55 .

Para os caracteres altura da planta e altura da espiga, as estimativas da variāncia genētica aditiva, em $(\mathrm{cm} / \mathrm{planta})^{2}$, foram bastante similares nas duas densidades populacionais para cada população, ficando, respectivamente, em torno de 229,80 e 236,70 para a população $K$, e ao redor de 176,40 e 171,80 para a população KT.

No que diz respeito ao progresso esperado com a seleção massal, a população KT apresentou um ganho de 5,56 gramas por planta na densidade baixa e 4,48 gramas por planta na densidade alta, ao passo que a população k mostrou um ganho de 4,64 e 2,89 gramas por planta, respectivamente, nas densidades baixa e alta.

Os ünicos resultados encontrados para uma população totalmente exótica (GC), derivada do cruzamento de uma variedade do Canadä e três variedades da Colômbia, foram obtidos por SUBANDI e COMPTON (1974), que usaram o Delinea mento I e avaliaram as progēnies em duas densidades populacionais (baixa: 17.222 pl/ha e alta: $68.888 \mathrm{pl} / \mathrm{ha}$ ). As estimativas obtidas para a variação genética aditiva $\left(\hat{\sigma}_{A}^{2}\right)$ foram $2.932,14(\mathrm{~g} / \mathrm{p} 1)^{2}$ e $171,03(\mathrm{~g} / \mathrm{p} 1)^{2}$, respectivamente, para a densidade baixa e alta, e considerando o caráter produção. Com relação ao caräter altura daplanta, as estimativas de $v_{A}^{2}$ foram 428,89 (cm/pl $)^{2}$ e $345,08(\mathrm{~cm} / \mathrm{pl})^{2}$, enquanto que para altura da espiga as estimativas de $\sigma_{\mathrm{A}}^{2}$ foram 345,95 $(\mathrm{cm} / \mathrm{pl})^{2}$ e $381,62(\mathrm{~cm} / \mathrm{pl})^{2}$, respectivamente, para as densida des baixas e altas.

Um composto semi-exótico (IC-DC), formado a partir de duas populações divergentes (Indian Chief-adaptado 
$x$ Diente de Caballo-exótico), se constituiu na população base para os estudos de MOLL e SMITH (1981), que conduziram cinco ciclos de seleção recorrente com irmãos germanos e pro gênies $S_{1}$. Os objetivos destes estudos foram caracterizar os componentes de variação genética para produção, antes e depois da seleção, e comparar as respostas esperadas combase nas estimativas de variāncia versus as respostas observadas experimentalmente. Verificaram que no composto IC-DC, a estimativa da variância genética aditiva foi $1.146,40$ (g/ $\mathrm{p} 1)^{2}$ antes da seleção, e de $728,50(\mathrm{~g} / \mathrm{pl})^{2}$ apōs a seleção. No que diz respeito às estimativas dos componentes de variān cia das progēnies, constataram que a seleção resultou em uma redução da variância genética em aproximadamente 1/3, tanto para irmãos germanos quanto para $S_{1}$. Constataram também que, todas as estimativas de respostas observadas por ciclo de se leção foram consideravelmente menores que as preditas através das estimativas dos componentes de variância. Apesar da diminuição da variabilidade genética, concluiram que os resultados obtidos foram encorajadores, uma vez que a produção média e o progresso esperado no composto semi-exötico IC-DC foram equivalentes aos resultados exibidos por duas populações adaptadas, que são materiais básicos para muitos progra mas de seleção recorrente. 


\title{
3. Material e métodos
}

\author{
3.1. Material
}

Foram utilizadas duas raças brasileiras de mi tho e uma populaçäo melhorada e adaptada às condições locais, sendo que dois hibridos duplos comerciais serviram como testemunhas. A seguir, uma breve descrição dos materiais é apresentada.

\section{$-E S A L Q-P B I$}

E uma população que foi obtida no Departamento de Genética da ESALQ/USP, sendo originalmente chamada de Composto Planta Baixa (MIRANDA FILH•, 1974 e 1977). Foi for mada a partir da combinação das seguintes populações: Tuxpe ño Crema I, Mezcla Amarilla, Eto Blanco Planta Baja, Antigua Grupo 2, Meb, Piracar e Cateto Argentina-Uruguai. Apresenta nas condições locais, porte e ciclo intermediärios, boa produtividade, sementes amarelas e variāveis quanto ao tipo (PA TERNIANI et alii, 1977). Após trés ciclos de recombinação, efetuou-se uma seleção massal estratificada em 1975/76, sendo selecionadas 1.000 familias de meios irmãos (FMI), as 
quais foram avaliadas no ano agricola de 1976/77 (MIRANDA FI LHO, 1977). A partir daqui, o programa foi dividido em duas secções :

A. Seleção recorrente com familias de meios irmãos - iniciou -se com a avaliação de 1.000 familias de meios irmãos em $1976 / 77$ com seleção de $10 \%$ entre familias; foram completa dos dois ciclos de seleção (MIRANDA FILHO, 1979). Do 1ote de recombinação no segundo ciclo de seleção, foram selecionadas 196 espigas (familias de meios-irmãos) e que se constituiram parte do material do presente estudo. E ta população, doravante serà denominada E.

B. Seleção recorrente e obtenção de linhagens e sintéticos das 1.000 familias avaliadas em 1976/77, foram recombinadas $2 \%$ e selecionadas 147 familias de meios-irmãos, das quais foram selecionadas 30 no segundo ciclo de seleção. As 30 familias de meios irmãos selecionadas foram plantadas em espiga por fileira, fazendo-se seleção e autofecun dação das plantas dentro de fileiras. Destas foram selecionadas 100 familias $S_{1}$ que foram plantadas e recombinadas, dando origem a ESALQ-PB1 (S). Deste programa também foi iniciada a obtenção de 1 inhagens endogâmicas para a utilização em híbridos.

\section{- Cravo}

A amostra representativa do germoplasma da ra ça Cravo Rio Grandense foi fornecida pelo Centro Nacional de Pesquisas de Milho e Sorgo (CNPMS), e. seus caracteres particulares são apresentadas na Tabela 8 , ressaltando-se, en tre elas, o grande número de fileiras por espiga. Segundo PATERNIANI e GOODMAN (1977), o tipo de milho apresentado por esta raça não tem importância comercial, uma vez que são 1 on 
gos e estreitos. Esta raça foi cruzada com a população ESALQ -PB1 (S) resultando numa população semi-exótica, doravante denominada EC, sendo posteriormente efetuadas duas recombina ções para dar origem a 196 familias de meios irmãos. Estas familias se constituiram no material base para o desenvolvimento do presente trabalho, contendo, desta forma, 50\% de g e nes do material adaptado e 50\% de genes da raça mencionada.

\section{- Ertrezacado}

Os germoplasmas representativos da raça Entre 1 açado encontram-se distribuidos pela região Amazónica, apre sentando pobre adaptação para a região Centro-Sul (PATERNIANI e GOODMAN, 1977). A amostra utilizada foi fornecida pelo CNPMS, podendo-se verificar seus caracteres principais na Tabela 8, destacando-se, entre elas, o acentuado compri mento da espiga. O cruzamento desta raça com a população ESALQ-PB 1 (S) resultou numa população semi-exótica doravante denominada EE; posteriormente, duas recombinações foram rea1 izadas, sendo, então, escolhidas 196 familias de meios irmãos para a realização do presente estudo. Estas familias continham, pois, $50 \%$ de genes do material adaptado e $50 \%$ de genes da raça exótica.

\section{- Testemunhas}

Dois hibridos duplos comerciais foram utiliza dos como testemunhas. O Agroceres 401, apresenta grãos semi -dentados e de coloração alaranjada; o Cargill 511 apresenta grãos dentados e de coloração amarela. Estes hỉbridos têm mostrado boas produtividades e atributos agronómicos satisfa tórios nos cultivos comerciais. 
.41.

TABELA 8. Médias dos principais caracteres, referentes às raças de milho Cravo e Entrelaçado, obtidas em Piracicaba - SP, Adaptada de PATERNIANI e GOODMAN (1977).

\begin{tabular}{|c|c|c|c|}
\hline Caracteres & Unidade & Cravo & Entrelaçado \\
\hline Altura de planta & $\mathrm{cm}$ & 249,00 & 283,00 \\
\hline Altura de espiga & $\mathrm{cm}$ & 119,00 & 151,60 \\
\hline Nọ de ramificações pendão & $\mathrm{n} \stackrel{0}{0}$ & 23,80 & 32,30 \\
\hline Comprimento da espiga & $\mathrm{cm}$ & 15,50 & 29,20 \\
\hline No fileiras por espiga & $\mathrm{n} !$ & 19,40 & 13,00 \\
\hline No grãos por fileira ${ }^{+}$ & $\mathrm{n} \stackrel{9}{1}$ & 28,00 & 15,00 \\
\hline Diâmetro da espiga & $\mathrm{cm}$ & 4,82 & 3,86 \\
\hline Diâmetro do sabugo & $\mathrm{cm}$ & 3,14 & 2,99 \\
\hline
\end{tabular}

+ Dados fornecidos pelo CNPMS - Sete Lagoas - MG

\subsection{Métodos}

3.2.1. Cruzamentos e obtenção das famīitias de meios irmãos

A primeira fase se constituiu na obtenção das populações semi-exóticas EC e EE. Em dezembro de 1981 foram plantados dois lotes contíguos com a população ESALQ-PB1 (S) e um lote para cada uma das raças. O plantio destes lotes foi feito em diferêntes épocas, a fim de haver coincidéncia de florescimento para possibilitar os cruzamentos. As espi gas da população ESALQ-PB1 (S) foram protegidas antes da emissão dos. estilo-estigmas, e no momento apropriado foram cruzadas manualmente com o pölen das raças Cravo e Entrelaça do. Em maio/82, efetuou-se a colheita individualizada para cada cruzamento e para cada raça, preparando-se em seguida 
uma amostra que continha o mesmo nümero de grãos de aproxima damente 250 espigas.

A segunda fase foi constituida pelo plantio das sementes $F_{1}$, em dois lotes isolados de recombinação, em uma ärea aproximada de $4.000 \mathrm{~m}^{2}$. O plantio foi feito em agosto/82, no município de Matão-sP, sendo a colheita realiza da em dezembro. Nesta ocasião, em cada um dos lotes foram tomadas ao acaso 250 plantas competitivas.

As espigas colhidas foram debulhadas individu almente no laboratörio, sendo retirados 50 grãos de cada espiga, os quais foram misturados para reconstituirem duas novas amostras para o plantio da segunda recombinação.

As sementes $F_{2}$ das populações EC e EE foram plantadas em fevereiro/83 nume ärea do Departamento de Genética, medindo cada lote cerca de $3.000 \mathrm{~m}^{2}$. Nesta terceira fase, a recombinação foi feita manualmente, coletando-se pólen de no minimo 50 pendés, misturando-o e polinizando as espigas que estavam com os estilo-estigmas receptivos. Foram realizadas cerca de 1.500 polinizações para cada população, obtendo-se cerca de 500 familias de meios irmãos de cada população; destas, 196 foram tomadas para a avaliação em ensaios, correspondendo, dessa maneira, às populações semi-exó ticas Cravo $x$ ESALQ-PB1 (EC) e Entrelaçado $x$ ESALQ-PB1 (EE).

\subsubsection{Execução experimental}

As 196 familias de meios irmãos das populações E, EC e EE foram avaliadas no municipio de Piracicaba -SP, em duas äreas experimentais (1ocais), Caterpillar e $\AA-$ gua Santa, no ano agricola de 83/84. Para isto, foram insta lados quatro experimentos, para cada uma das populações, no 
delineamento em lätice triplo $7 \times 7, \operatorname{com} 3$ repetições em dois locais. As testemunhas Ag-401 e C-511 foram colocadas sistematicamente no início e final de cada experimento, para cada uma das populações.

0 plantio da Caterpillar foi realizado em 05. 10.83, e na Ågua Santa em 20.10.83, em solos classificados como latossol vermelho amarelo de textura média e terra roxa estruturada, respectivamente, para o primeiro e segundo 1ocal. O espaçamento adotado foi de $1 \mathrm{~m}$ entre fileiras e 0,20 m entre plantas dentro de fileiras, sendo a unidade experimental constituida por uma fileira de $5 \mathrm{~m}$ de comprimento. Fo ram colocadas 2 sementes por cova; 15 dias apös a germinaçáo efetuou-se o desbaste para uma planta por cova, procurando -se manter um "stand" ideal de 25 plantas por parcela. O de senvolvimento da cultura foi feito dentro dos mesmos padróes dos cultivos comerciais, e a precipitação pluviométrica foi considerada satisfatória. Os ensaios foram um pouco prejudí cados, em decorréncia dos fortes ventos ocorridos no período de florescimento, o que causou um acamamento acentuado na maioria das parcelas.

Foram anotados os dados de dez caracteres, para cada uma das populações no local 1 (Caterpillar), sendo que no local 2 (Āgua Santa) foram anotados os dados de peso de espigas e peso de grãos, conforme discriminação mostrada a seguir:

- AP e AE - altura de planta e de espiga - em cada parcela, foram escolhidas ao acaso cinco plantas competitivas; a 1 tura de planta foi medida em metros, da superficie do solo até a inserção da ültima fôlha, enquanto que para altura de espiga, a medição foi efetuada da superficie do solo até a inserção basal da primeira espiga; 
- NRP - número de ramificafões do pendão - após a completa 1 iberação do pólen, cinco plantas competitivas foram tomadas ao acaso dentro de cada parcela. Os pendões foram cor tados na parte basal, amarrados e etiquetados. No laboratório efetuou-se a contagem do nümero total de ramificacões, para cada um dos pendões;

- PE - peso de espigas - após a colheita, as espigas despaIhadas foram levadas para o laboratório e pesadas numa balança eletrōnica marca Toledo, com uma capacidade máxima para dez quilos e com uma sensibilidade para dez gramas;

- DE e CE - diâmetro de espiga e comprimento de espiga - após a tomada do peso de espigas, foram selecionadas ao acaso, cinco espigas para a realização destas mensurações. Para isto, utilizou-se de uma caixa que tinha uma régua fixada na parte central, paralela no sentido do lado maior da ca xa. As cinco espigas foram colocadas juntas e em disposição alternada sobre a rëgua, sendo medido em centimetros o diāmetro total da parte mediana. O CE foi tomado em centí metros, colocando-se individualmente as espigas sobre a ré gua ;

- NFE e NGE - nümero de fileiras por espiga e nümero de grãos por fileira - após a medição do DE e CE, nas mesmas cinco espigas foram contados individualmente o NFE e NGF. Estes da dos foram tomados em apenas um experimento, para cada pop 1 ação, e em um local;

- PG - peso de gräos - as espigas de cada parcela foram debu 1 hadas, e os grãos foram pesados na mesma balança jä mencionada. Após a pesagem de cada parcela, foram retirados ao acaso, 18 amostras de grãos de cada experimento, para posterior determinação de umidade; 
- DS - diāmetro do sabugo - após a debulha das espigas de cá da parcela, foram escolhidos ao acaso, cinco sabugos, os quais foram colocados juntos para a medição do diâmetro to tal, em centimetros. O procedimento usado foi idēntico ao feito para DE.

A determinação do teor de umidade dos grãos foi feita em um aparelho "Steinlite", constatando-se uma boa uniformização na umidade dos tratamentos, ao redor de 16,2\%, de modo que o peso de grãos neste trabalho refere-se àquele teor de umidade médio.

Em decorrência dos ensaios apresentarem varia ção quanto ao "stand" final, foram realizadas correções para $P E$ e PG para o "stand" ideal de 25 plantas, utilizando-se do método de correção por covariância (STEEL e TORRIE, 1960), in troduzindo-se uma modificação na metodologia. Desta forma, as anālises de variância e covariância para "stand" e produção foram realizadas como blocos casualizados. Desta anảlise foi estimado o coeficiente de regressão linear (b), calcu 1 ado com a soma de quadrados residual da anälise de variância para "stand" $\left(\mathrm{SQ}_{\mathrm{X}}\right)$ e com a soma de produtos residual da anālise de covariāncia stand $x$ produção ( $\mathrm{SP}_{\mathrm{xy}}$ ), i.sto é, $\mathrm{SP}_{\mathrm{xy}}{ }^{\prime}$ $S Q_{X}$, sendo $x$ e y referentes, respectivamente, ao "stand" e produção. A correção foi feita ao nivel de totais de parce1 as, ao invés de médias dos tratamentos. Desta forma, o peso de campo corrigido ( $P c$ ) foi obtido da seguinte maneira:

$$
P c=P-\beta(x-25), \quad \text { onde: }
$$

P : peso observado de espigas ou de grãos;

$\beta$ : coeficiente de regressão 1 inear do peso de espigas ou de grãos, em relação às variações do "stand";

$x$ : stand observado. 


\subsubsection{Anälise estatistico-genética}

As anảlises de 1 àtice foram realizadas no com putador IBM-1130 do Departamento de Matemática da ESALQ/USP, segundo o procedimento dado por CoCHRAN e COX (1957). É necessário mencionar, por outro lado, que somente para os caracteres peso de espigas (PE) e peso de grãos ( $P G$ ) é que as anả ises de variância foram efetuadas considerando os dados de cada um dos locais, sendo em seguida realizada uma anàlise conjunta. Para os demais caracteres, as anälises foram feitas com os dados de um só local (Caterpil1ar).

Para cada um dos caracteres, em um local, o modelo matemático utilizado foi:

$$
Y_{i j k}=\mu+p_{i}+q_{j}+b_{k(j)}+e_{i j k}, \text { onde: }
$$

$Y_{i j k}$ : média da progēnie i no bloco k da repetição j;

H: média geral;

$p_{i} \quad$ : efeito aleatörio da progênie i; $\left(i=1,2, \ldots, I_{;}\right)$; $E\left(p_{i}\right)=0$ e $E\left(p_{i}^{2}\right)=\sigma_{p}^{2}$

$q_{j} \quad$ : efeito aleatório da repetição $j$;

$b_{k(j)}$ : efeito aleatörio do blocok, na repetição j;

$e_{i j k}$ : erro intrabloco, ou seja, erro experimental associado ao tratamento i, dentro do bloco k na repetição j; $E\left(e_{i j k}\right)=0$ e $E\left(e_{i j k}{ }^{2}\right)=\sigma_{e}^{2}$.

Considerando os dados obtidos para PE e PG nos dois locais o modelo matemàtico para a a àlise conjunta foi :

onde:

$$
\left.Y_{i j m}=\mu+p_{i}+1_{m}+q_{j(m}\right)+p 1_{i m}+e_{i j m},
$$

$Y_{i j m}:$ média da progênie i na repetição j do 1 ocal m; 
$\mu \quad:$ média geral ;

$p_{i} \quad$ : efeito aleatório da progēnie i;

$1_{\mathrm{m}}$ : efeito aleatório do local m;

$q_{j(m)}$ : efeito aleatório da repetição $j$ dentro do 1 ocal m;

plim: efeito aleatório da interação progênies x locais;

$e_{i j m}$ : erro efetivo médio associado ao tratamento i, na repe tição j dentro do local m.

Os esquemas das análises de variāncia e as es peranças matemáticas dos quadrados médios para todos os caracteres em, um local, são mostrados na Tabela 9. Para a anàlise conjunta de variância, o esquema da anảlise e as esperanças matemáticas dos quadrados médios são apresentados na Tabe 1 a 10 .

\subsubsection{Estimativas dos componentes de variāncia}

A obtenção e interpretação dos componentes ge nëticos das esperanças dos quadrados médios foram feitas de acordo com a metodologia relatada por Vencovsky (1969). Uma vez que não foram tomados dados individuais para os caracteres peso de espigas e peso de grãos, utilizou-se da re1 ação $\hat{\sigma}_{\mathrm{d}}^{2} / \hat{\sigma}_{\mathrm{e}}^{2}=10$, citada por GARDNER (1961).

As estimativas das variāncias genéticas e ambientais foram obtidas ao nivel de médias de parcelas. De acordo com as esperanças matemáticas dos quadrados médios, conforme constam na Tabela 9 , foram obtidas as estimativas da variância genética entre familias de meios irmãos $\left(\hat{\sigma}_{p}^{2}\right)$, da variância do erro ambiental entre parcelas $\left(\hat{\sigma}_{\mathrm{e}}^{2}\right)$ e da variância fenotipica dentro de familias de meios irmãos $\left(\hat{o}_{d}^{2}\right)$, para cada uma das populações e em cada um dos locais. 

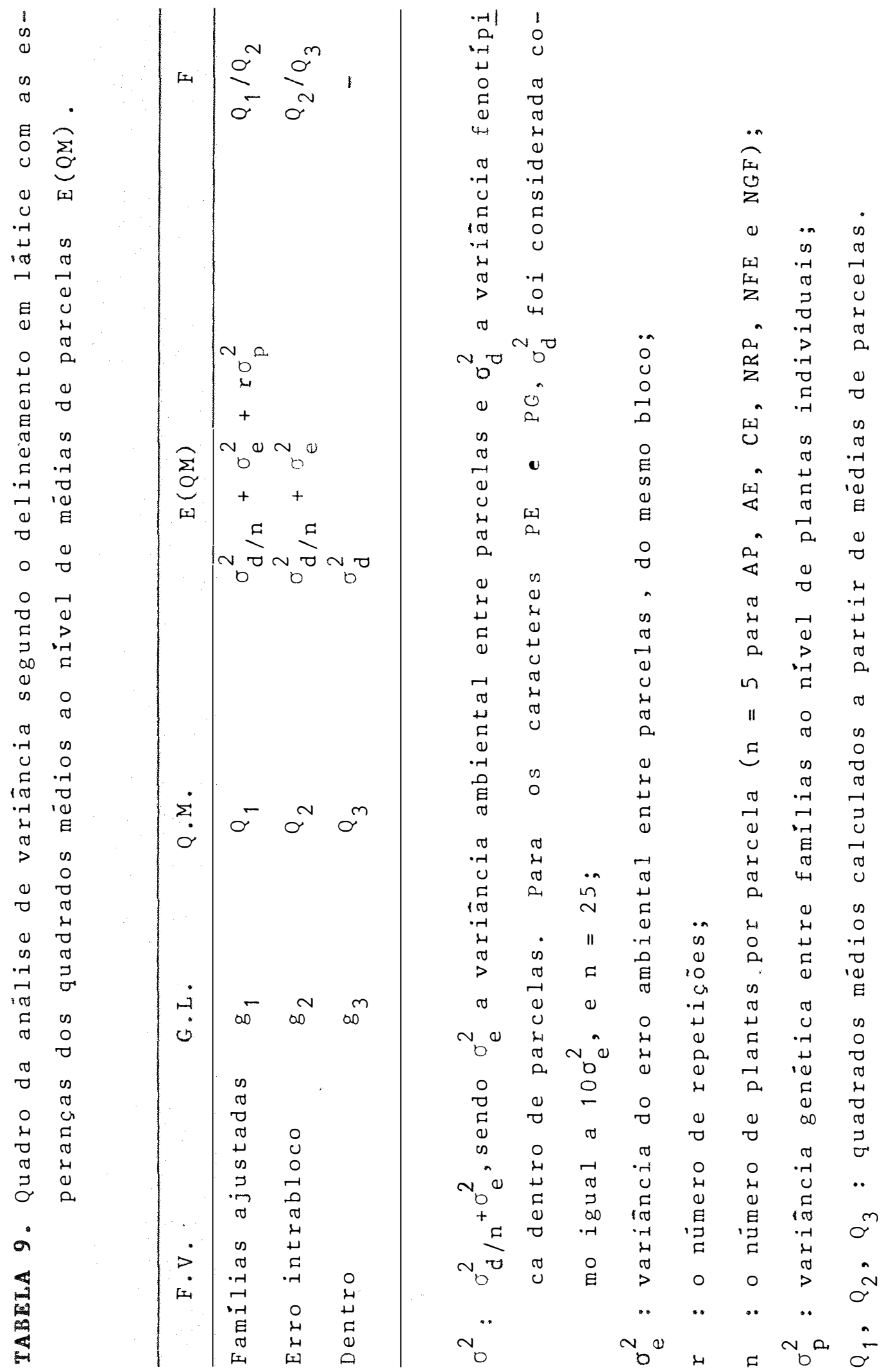
TABELA 10. Quadro da anảlise de variāncia e esperança matemá tica dos quadrados médios [E(QM)] obtidos na anälise de variāncia conjunta, para os caracteres pe so de espigas e peso de grãos, ao nivel de médias de parcelas.

\begin{tabular}{|c|c|c|c|c|c|}
\hline F.V. & G. L . & Q.M. & & $E(Q M)$ & $\mathrm{F}$ \\
\hline Tratamentos ajustados & $g_{\mathrm{T}}$ & $\mathrm{Q}_{\mathrm{T}}$ & $\sigma^{2} / \mathrm{r}$ & $+\sigma_{p 1}^{2}+1 \sigma_{p}^{2}$ & $\mathrm{Q}_{\mathrm{T}} / \mathrm{Q}_{\mathrm{TL}}$ \\
\hline Tratamentos $x$ Locais & $\mathrm{g}_{\mathrm{TL}}$ & $\mathrm{Q}_{\mathrm{TL}}$ & $\sigma^{2} / r$ & $+\sigma_{\mathrm{pl}}^{2}$ & $\mathrm{Q}_{\mathrm{TL}} / \overline{\mathrm{Q}}_{2}$. \\
\hline Erro efetivo médio & $\mathrm{g}_{\mathrm{E}}$ & $\bar{Q}_{2}$. & $\sigma^{2} / r$ & & \\
\hline
\end{tabular}

$\sigma_{\mathrm{p}}^{2}$ : variāncia genética entre mèdias de famílias;
$\sigma_{\mathrm{p} 1}^{2}$ : variāncia da interação tratamentos $\mathrm{x}$ 1ocais;

1 : nümero de locais;

r : nümero de repetições;

$g_{E}$ : soma dos graus de liberdade do erro nos dois locais;

$\bar{Q}_{2}$. : média dos quadrados médios dos erros efetivos dos dois Iocais;

$\sigma^{2}: \sigma_{\mathrm{d} / \mathrm{n}}^{2}+\sigma_{\mathrm{e}}^{2}$ 
Assim sendo, para peso de espigas e peso de grãos, o processo adotado foi o seguinte:

$\hat{\sigma}_{\mathrm{p}}^{2}=\left(Q_{1}-Q_{2}\right) / r ; \hat{\sigma}_{\mathrm{e}}^{2}=n\left(Q_{2}\right) /(n+10) ; \hat{\sigma}_{\mathrm{d}}^{2}=10 \hat{\sigma}_{\mathrm{e}}^{2}$, sendor o nü mero de repetições e n o nümero de plantas por parcela.

Para os demais caracteres exceto DE e DS que não foram tomados dados individuais, adotou-se o seguinte procedimento:

$$
\hat{\partial}_{\mathrm{p}}^{2}=\left(\mathrm{Q}_{1}-\mathrm{Q}_{2}\right) / \mathrm{r} ; \hat{\sigma}_{\mathrm{e}}^{2}=\left(\mathrm{Q}_{2}-\mathrm{Q}_{3} / \mathrm{n}\right) ; \hat{\sigma}_{\mathrm{d}}^{2}=\mathrm{Q}_{3}
$$

onde:

$\hat{\sigma}_{p}^{2}=$ variância genética entre familias de meios irmãos;

$\hat{\partial}_{\mathrm{A}}^{2}=4 \hat{\partial}_{\mathrm{p}}^{2}$ : variância genética aditiva;

$\hat{\partial}_{F}^{2}=\hat{\sigma}_{p}^{2}+\hat{\sigma}_{e}^{2}+\hat{\partial}_{d}^{2}$ : variāncia fenotipica ao nivel de plantas;

$\hat{\partial} \frac{2}{\mathrm{~F}}=\hat{\partial}_{\mathrm{p}}^{2}+\hat{\sigma}_{\mathrm{e} / \mathrm{r}}^{2}+\hat{\partial}_{\mathrm{d} / \mathrm{nr}}^{2}$ : variância fenotipica entre médias de familias de meios irmãos;

$\hbar^{2}=\partial_{A}^{2} / \partial_{F}^{2}$ : herdabilidade no sentido restrito ao nivel de plantas;

$\hbar \frac{2}{\mathrm{x}}=\hat{\partial}_{\mathrm{p}}^{2} / \partial \frac{2}{\mathrm{~F}}$ : herdabilidade no sentido restrito ao nivel de médias de familias.

A partir destas estimativas, foram obtidos os seguintes parãmetros:

a. Coeficiente de variação genética: CVg\% $=100$. $\hat{\theta}_{p} / \mu$

b. Coeficiente de variação experimental: CVe\% $=100 \cdot \sqrt{Q_{2}} / \mu$

c. Indice de variação: $\hat{\theta}=\mathrm{CVg} / \mathrm{CV}$ e

os progressos genéticos esperados foram obti- 
dos conforme as expressões dadas por VEnCOVsky (1978):

$$
\Delta_{S}=k^{\prime}(1 / 4) \hat{\sigma}_{A}^{2} / \sigma_{\vec{F}}+k^{\prime \prime}(3 / 8) \hat{\sigma}_{A}^{2} / \sigma_{d} ; \Delta_{S^{\prime}}=k^{\prime \prime} \partial_{A}^{2} / \sigma_{F}
$$

$\Delta_{S}=$ progresso esperado com seleção entre e dentro de fami1 ias de meios irmãos, com sementes remanescentes;

$\Delta_{S^{\prime}}=$ progresso esperado com seleção massal em ambos os sexos;

$k^{\prime}=$ diferencial de seleção estandardizado, correspondente

a uma intensidade de seleção de $20 \%\left(k^{\prime}=1,3998\right)$;

$\mathrm{k}^{\prime \prime} \quad$ = diferencial de seleção estandardizado, correspondente

a uma intensidade de seleção de $10 \%\left(k^{\prime \prime}=1,755\right)$;

$\sigma_{\bar{F}} \quad$ desvio padrão fenotipico entre médias de familias de meios irmãos;

$\sigma_{F}=$ desvio padrão fenotipico entre plantas;

$\sigma_{\mathrm{d}} \quad$ desvio padrão fenotipico dentro de familias de meios irmãos.

Considerando a anàlise conjunta para os carac teres peso de espigas e peso de grãos (Tabela 10), idēn tico procedimento foi adotado para cada uma das populações nos dois locais, para obtenção das estimativas das variāncias genética e ambiental. Foram obtidas, desta forma, as estimativas das variâncias genéticas entre familias de meios irmãos $\left(\hat{\sigma}_{p}^{2}\right)$, variància do erro ambiental entre parcelas ( $\left.\hat{\sigma}^{2}\right)$, variância fenotipica dentro de familias de meios irmãos $\left(\hat{\partial}_{\mathrm{d}}^{2}\right)$, e variância da interação tratamentos $x$ locais $\left(\partial_{\mathrm{p}}^{2}\right)$ :

$$
\hat{\partial}_{\mathrm{p}}^{2}=Q_{\mathrm{T}}-Q_{\mathrm{TL}} / 1 ; \hat{\sigma}_{\mathrm{pl}}^{2}=Q_{\mathrm{TL}}-\bar{Q}_{2}
$$

$\partial_{e}^{2}$ e $\partial_{d}^{2}$ da anälise conjunta foram obtidas pela mëdia das estimativas das anàlises individuais.

A partir destas estimativas foram calculadas: 
$\hat{\sigma}_{\mathrm{A}}^{2}=4 \hat{\partial}_{\mathrm{p}}^{2}$ : variância genética aditiva;

$\hat{\partial}_{\mathrm{F}}^{2}=\partial_{\mathrm{p}}^{2}+\hat{\partial}_{\mathrm{pl}}^{2}+\partial_{\mathrm{e}}^{2}+\hat{\partial}_{\mathrm{d}}^{2}$ : variância fenotipica ao nivel de plantas;

$\hat{\partial} \frac{2}{\mathrm{~F}}=\hat{\partial}_{\mathrm{p}}^{2}+\hat{\partial}_{\mathrm{p} 1 / 1}^{2}+\hat{\sigma}_{\mathrm{e} / 1 \mathrm{r}}^{2}+\hat{\sigma}_{\mathrm{d} / 1 \mathrm{rn}}^{2}$ : variância fenotipica entre médias de familias de meios irmãos;

$\hat{h}^{2}=\partial_{A}^{2} / \partial_{F}^{2}$ : herdabilidade no sentido restrito ao nivel de plantas ;

$\hbar \frac{2}{\mathrm{x}}=\hat{\partial}_{\mathrm{p}}^{2} / \hat{\partial} \frac{2}{\mathrm{~F}}$ : herdabilidade no sentido restrito ao nivel de familias.

o progresso genético esperado com SEDFMI, o coeficiente de variação genética e o indice de variação $\theta$ fo ram calculados de acordo com as förmulas anteriormente mencionadas, substituindo-se apenas as estimativas pelas atuais.

o progresso geriético esperado com seleção mas sal foi obtido através da média do local 1 e 2 , sendo,porém, isolado o efeito de local da variãncia genética aditiva de cada local. Procedendo desta maneira, a estimativa do progresso fica mais realista, uma vez que o efeito da seleção massal em mais de um local, será função da variāncia aditiva que se expressa no conjunto de locais.

Assim sendo, conforme sugestão de MIRANDA FILHO (1985)\%, utilizou-se a seguinte expressão:

$$
\begin{aligned}
\Delta_{S} "= & =1 / 2\left[\mathrm{k}^{\prime \prime} \cdot \hat{\sigma}_{\mathrm{A}}^{2}\left(\frac{1}{\sigma_{\mathrm{FL}}}+\frac{1}{\sigma_{\mathrm{FL}}}\right)\right] \text {, onde: } \\
\Delta_{\mathrm{S}} " \quad= & \text { progresso genético esperado com seleção massal em am } \\
& \text { bos os sexos, com à média dos } \mathrm{L}_{1} \text { e } \mathrm{L}_{2} ;
\end{aligned}
$$

(*) MIRANDA FILHO, J.B., 1985. Informação pessoa 1 


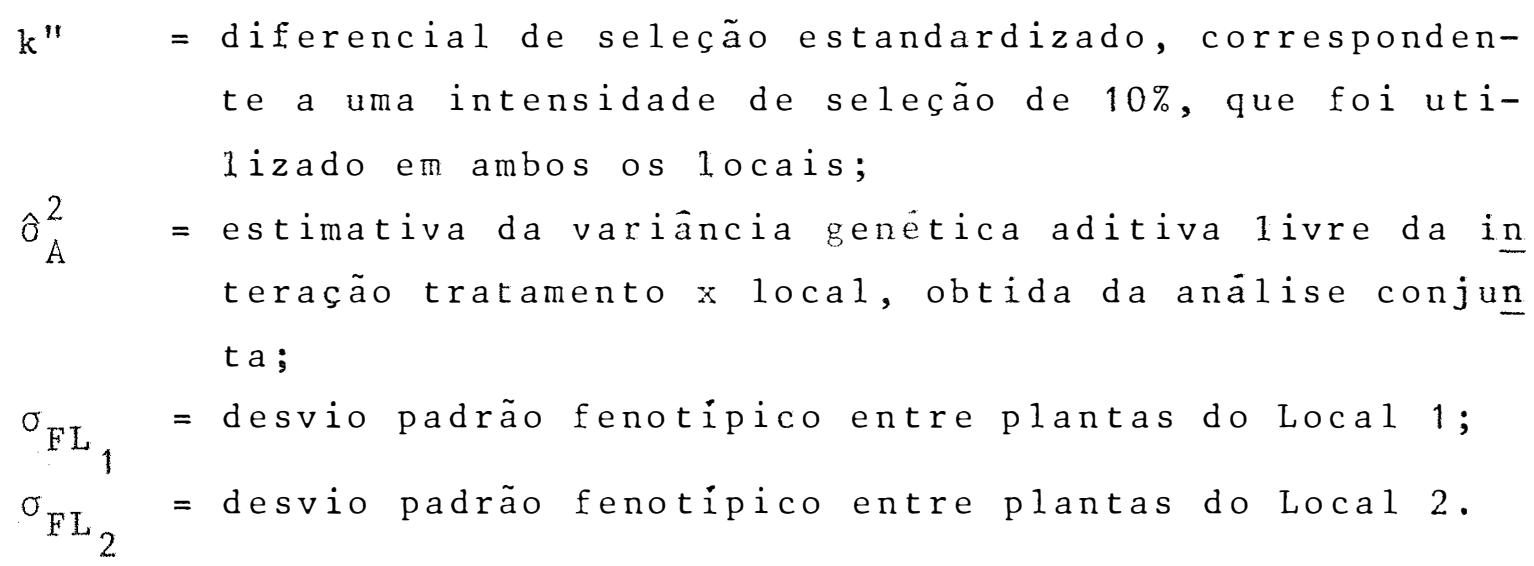




\section{RESULTADOS}

Da mesma forma como os caracteres de produção, de planta e de espiga foram agrupados para a revisão de literatura, idêntico procedimento foi adotado para a apresen tação dos resultados. Por outro 1ado, é necessärio sa1ientar que somente os caracteres de produção foram avaliados nos dois locais, tendo sido os demais avaliados em um 1ocal.

Enecessärio lembrar que, apesar dos resultados aqu apresentados serem referentes à progēnies obtidas do segundo ciclo de recombinação, alguns comentärios merecem ser feitos para os cruzamentos iniciais e para cada uma das recombinações.

Para a realização dos cruzamentos intervarietais, as populações representativas das raças Cravo e Entrelaçado foram plantadas em lotes adjacentes com a população ESALQ-PB 1, com defasagem de plantio para contornar diferenças de época de florescimento. Nos cruzamentos, a população ESALQ-PB 1 foi utilizada como fémea, para garantia de um bom suprimento de sementes. Os cruzamentos com Cravo foram mais fäceis de serem realizados, visto que esta raça não apresen- 
tou problemas 1 imitantes de adaptação. Por outro lado, os cruzamentos com Entrelaçado foram mais dificeis de serem rea lizados, devido ao mal desenvolvimento das plantas, que apre sentaram alta incidência de doença e elevado indice de acamamento, dificultando inclusive a coleta de pólen. Em ambos os casos, os cruzamentos foram realizados planta à planta,em nümero suficiente $(N \cong 250)$ para garantir um bom suprimento de sementes e um elevado tamanho efetivo populacional.

Na primeira recombinação, verificou-se o desenvolvimento normal dos dois campos de recombinação, observando-se plantas bem vigorosas e com boa formação de espigas em cada uma das populações. Antes da colheita, foram to madas, ao acaso, 250 plantas competitivas de cada população, realizando-se medições para altura da planta (AP) e da espiga (AE). Para a população Cravox ESALQ-PB1 (EC), as médias obtidas para AP e AE foram, respectivamente, 226 e 141 cm/ planta, enquanto que para a população Entrelaçado x ESALQPB 1 (EE) foram 252 e 152 cm/planta. Estes valores, embora não comparäveis diretamente com os da Tabela 8 , mostram que os hibridos EE e EC apresentam um diferencial de altura da planta e da espiga semelhante aos observados nas raças paren tais (Entrelaçado e Cravo).

Após a colheita das plantas, foram tomadas ao acaso 100 espigas de cada uma das populações, obtendo-se uma média de $22 \mathrm{~cm}$ de comprimento da espiga para a população EE, e uma média de 18,16 para o número de fileiras por espiga para a população EC. Em relação às médias das raças Cravo e Entrelaçado (Tabela 8), estes valores foram mais baixos, para os respectivos caracteres avaliados, indicando que o cruzamento com a população base (ESALQ-PB1) fez diminuir a média dos caracteres peculiares de cada raça, quais sejam, es piga longa na raça Entrelaçado e grande nümero de fileiras na raça Cravo. 
Ressalte-se também que nesta primeira recombi nação, a população EE apresentou 100\% de fileiras regulares nas espigas, indicando que a caracteristica "entrelaçado" é determinada por gene(s) recessivo(s).

Um fato que merece ser destacado foi a grande segregação ocorrida nas sementes $\mathrm{F}_{2}$ (plantas $\mathrm{F}_{1}$ ), para a coloração de grãos da população Entrelaçado x ESALQ-PB1 (EE). A raça Entrelaçado apresenta grãos de coloração vermelha-escura (pürpura), sendo que as sementes $\mathrm{F}_{2}$ exibiram gradações de cores de vermelha-escura (púrpura) até a branca. Nas sementes $\mathrm{F}_{3}$ (plantas $\mathrm{F}_{2}$ ), por outro lado, observou-se uma acen tuada diminuição para sementes de cor escura e intermediárias, predominando aquelas de cor clara.

Na segunda recombinação, observou-se uma segregação muito forte para AP e AE em cada população, não sen do possivel, no entanto, a realização de medições para estes caracteres, em decorréncia das fortes chuvas e ventos ocorri dos no periodo de florescimento. Por outro lado, estes imprevistos impossibilitaram tomada de dados para CE e NFE, de vido a proximidade entre a preparação e instação dos ensaios.

4.1. Produção

4.1.1. Anālise geral

os valores médios obtidos para os caracteres peso de espigas e peso de grãos, avaliados nos locais 1 e 2 (Caterpillar e §gua Santa) de Piracicaba-SP e referentes às très populações e à testemunha, encontram-se nas Tabelas 11 e 12 .

A Tabela 13 evidencia os valores médios obtidos para estes caracteres nos dois locais, verificando-se pa 
ra peso de espigas 126,$84 ; 117,45$ e 101,22 gramas por planta, correspondendo, respectivamente, às populações ESALQ-PB 1 (E), Cravo x ESALQ-PB1 (EC) e Entrelaçado x ESALQ-PB1 (EE), e que equivalem em t/ha, a 6,$34 ; 5,87$ e 5,06. Em relação à mëdia das testemunhas, estes valores correspondem à 91,62 ; $84,82 \%$ e $73,12 \%$, respectivamente, para as populações E, EC e EE .

As Figuras de 1 a 3 fornecem uma melhor visua 1 ização da distribuição das médias do peso de espigas para as très populações, em cada um dos locais e considerando a média dos dois locais, destacando-se os segregantes transgressivos em relação à população ESALQ-PB1.

Para peso de grãos, conforme pode ser visto na Tabela 13, os valores médios encontrados nos dois locais foram 100,$08 ; 95,07$ e 80,22 gramas por planta, correspondendo, respectivamente, às populações E, EC e EE, e que equivalem a 5,00;4,74 e 4,00 t/ha. Em relação à média da testemu nha, estes valores correspondem a $88,74 \% ; 84,30 \%$ e $71,13 \%$, respectivamente, para as populações E, EC e EE.

A distribuição das médias do peso de grãos pạ ra as três populações, em cada um dos locais e considerando a média dos dois locais, é evidenciada nas Figuras 4 a 6 , podendo-se verificar os segregantes transgressivos em relaça à população ESALQ-PB 1 .

os valores e significāncias dos quadrados mëdios obtidos nas anälises agrupadas de variância para peso de espigas, em cada um dos locais e para as três populações, encontram-se nas Tabelas 17 e 18, enquanto que na Tabela 19 podem ser vistos os resultados da análise conjunta de variân cia. Pode-se observar, nesta tabela, que os quadrados mé- 
dios para a interação tratamentos $x$ locais foi significativa (teste F) apenas para as populações E e EE, sendo não significativa para EC.

Para todas as populações, os quadrados médios do caráter peso de espigas foram significativos para a varia ção entre familias de meios irmãos, tanto em cada local quan to na anälise conjunta.

Os coeficientes de variação experimental no local 1 estiveram em torno de $15 \%$, enquanto que no 1 ocal 2 foram, em média, $12 \%$. Considerando a análise conjunta, pode -se verificar que os coeficientes de variação experimental, para peso de espigas, foram $13,95 \% ; 15,34 \%$ e $15,06 \%$, respectivamente para as populações E, EC e EE.

$$
\text { Para o caráter peso de grãos, os va- }
$$
lores e significāncias dos quadrados médios obtidos nas anä1 ises agrupadas de variāncia, em cada um dos locais e para as três populações, podem ser vistos nas Tabelas 20 e 21 , sen do que a Tabela 22 evidencia os resultados da análise conjun ta, e mostra a significāncia detectada para a interação tratamentos x locais nas populações E e EE, e a não significāncia para a população EC. Por outro lado, pode-se averiguar a significancia para a variaço entre familias em todas as populações, tanto nas análises de variāncia de cada local quanto na análise conjunta.

Os coeficientes de variação experimental para peso de grãos foram em média $16,5 \%$ e $12,5 \%$, respectivamente, para o local 1 e 2 . Na análise conjunta, os valores obtidos foram $14,82 \% ; 16,10 \%$ e $16,00 \%$, respectivamente, para as popu 1 ações E, EC e EE. 
4.1.2. Estimativas de parâmetros genéticos

Em cada um dos $10 \mathrm{ca}$ is e para cada uma das populações, as estimativas das variāncias genéticas, para os caracteres peso de espigas e peso de grãos encontram-se nas Tabelas 23 e 24 , enquanto que na Tabela 25 são apresentadas as estimativas obtidas através da anảlise conjunta.

As estimativas da variāncia genética aditiva para o caráter peso de espigas no local 1 (Caterpillar) foram 290,5784; 152,6128 e 450,5628 (gramas/planta) ${ }^{2}$, e no $10-$ ca1 2 (Agua Santa) foram 264,0376;288,1652 e 428,2640 (gramas/planta) ${ }^{2}$, respectivamente, para as populações E, EC e EE.

Considerando a anälise conjunta, pode-se veri ficar que as estimativas das variancias genéticas aditivas para peso de espigas, em (g/planta ${ }^{2}$, foram 100,4820 para a população E, 186,1600 para EC e 283,0180 para EE. Na anälise conjunta para peso de grãos, as estimativas das variāncias genéticas aditivas foram 82,5580, 117,5000 e 201,5452, respectivamente, para as populações E, EC e EE.

Para peso de espigas, no local 1 , as estimatí vas dos coeficientes de herdabilidade no sentido restrito ao nivel de plantas individuais foram $10,14 \% ; 5,20 \%$ e $20,61 \%$, e para peso de grãos $10,41 \% ; 5,00 \%$ e $20,70 \%$, respectivamente para E, EC e EE.

Para peso de espigas no local 2, as estimativas dos coeficientes de herdabilidade no sentido restrito ao nivel de plantas individuais foram $14,45 \% ; 16,28 \%$ e $29,68 \%$, e para peso de grãos foram $12,85 \% ; 25,98 \%$ e 32,21\%, respecti vamente, para as populações E, EC e EE.

As estimativas dos coeficientes de herdabili- 
dade no sentido restrito ao nivel de médias de progènies variaram de um 1ocal para outro de $23,70 \%$ a $65,39 \%$, e de $22,97 \%$ a $67,37 \%$, respectivamente, para peso de espigas e peso de grãos, tendosido obtidos os valores mais elevados no local 2 .

Considerando a anälise conjunta para o caräter peso de espigas, as estimativas da herdabilidade no sentido restrito ao nivel de plantas individuais foram 4,32\%; $7,88 \%$ e $15,52 \%$, respectivamente, para as populaçóes E, EC e EE, sendo que para peso de grãos estas estimativas foram $5,15 \% ; 7,51 \%$ e $15,43 \%$.

Ao nivel de médias de progênies, as estimativas dos coeficientes de herdabilidade resultantes da anảlise conjunta foram $29,46 \% ; 44,23 \%$ e $54,00 \%$ para peso de espigas, ao passo que para peso de grãos foram $35,69 \% ; 42,44 \%$ e $53,14 \%$, correspondentes, respectivamente, às populações E, EC e EE.

A Tabela 25, mostra também que os valores estimados para as variancias da interação tratamentos $x$ locais foram 43,6787; 19,9700 e 48,2380 para peso de espigas, e 28,$8670 ; 15,1600$ e 37,1740 para peso de grãos, referentes, em ordem de estimativas, às populações E, EC e EE.

As estimativas dos progressos genéticos esperados, através dos processos de selecão entre e dentro de fa milias de meios irmãos com sementes remanescentes (SEDFMI) e de seleção massal em ambos os sexos (SM), encontram-se nas Tabelas 26 e 27 , quando foi considerado cada um dos 10 ais e cada uma das trés populações, para os caracteres peso de espigas e peso de grãos. Pode-se notar, de um modo geral, que as estimativas mais elevadas foram obtidas no local 2, para todas as populações e em qualquer um dos processos 
de seleção propostos.

Considerando-se a anảlise conjunta para os ca racteres peso de espigas e peso de grãos, a Tabela 28 mostra as estimativas dos progressos genéticos esperados por ciclo de seleção e o progresso genético em porcentagem, para cada uma das populações.

Para peso de espigas, as estimativas dos progressos esperados por ciclo de seleção com a SEDFMI foram 5,06; 9,04 e 13,40 gramas por planta, correspondentes às po pulações E, EC e EE, e equivalentes em porcentagema 3,99\%; $7,70 \%$ e 13,25\%; utilizando-se da seleção massal, estas estimativas por ciclo de seleção foram 3,$72 ; 6,92$ e 11,88 gramas por planta, correspondendo respectivamente às populações E, EC e EE, sendo equivalentes em porcentagem a $2,93 \%, 5,92 \%$ e $11,74 \%$.

Para peso de grãos, aś estimativas dos progressos esperados com SEDFMI para as populações E, EC e EE foram 4,93; 7,03 e 11,25 gramas por planta, correspondendo em porcentagem aos valores $4,94 \% ; 7,40 \%$ e $14,02 \%$; efetuando- se a seleção massal, as estimativas dos progressos genéticos esperados por ciclo de seleçãoforam 3,88; 5,53 e 10,00 gramas por planta, o que equivalem em porcentagem a $3,88 \%$; $5,82 \%$ e $12,46 \%$, respectivamente, para as populações E, EC e EE.

As estimativas dos coeficientes de variação

genëtica bem como dos indices de variação $\theta$ foram bem mais elevados no local 2 do que no local 1 , tanto para peso de es pigas quanto para peso de grãos, sendo que a população Entre 1 açado $x$ ESALQ-PB 1 apresentou as mais altas estimativas em ambos os locais. 
$\mathrm{Na}$ anālise conjunta de variāncia, as estimati vas dos coeficientes de variação genética para peso de espigas foram $3,95 \% ; 5,83 \%$ e $8,31 \%$, valores estes inferiores em $40 \%, 7 \%$ e $20 \%$ em relação à média das estimativas nos dois 1 o cais, e referentes às populações E, EC e EE. Decréscimos de $43 \%, 16 \%$ e $24 \%$ foram também verificados para as estimativas dos indices de variação $\theta$, cujos valores obtidos na anàise conjunta, foram 0,28; 0,38 e 0,55 , correspondentes às popula ções E, EC e EE.

Na anălise conjunta de variāncia para o caräter peso de grãos, as estimativas dos coeficientes de variação genética foram 4,55\%, 5,70\% e $8,84 \%$ para as populações E, EC e EE, valores estes, respectivamente, inferiores em $33 \%, 18 \%$ e $22 \%$ em relaçà à média das estimativas nos dois 1ocais. Decréscimos de $36 \%$, $34 \%$ e $26 \%$ foram também verifica dos para as estimativas dos indices de variação $\theta$, cujos valores obtidos foram 0,31 para a população E, 0,35 para EC e 0,55 para EE.

4.2. Caracteres da planta

\subsubsection{Anälise geral}

Os valores médios obtidos para altura da plan ta (AP), altura da espiga (AE) e numero de ramificaçós do pendão (NRP), referentes às très populações e à testemunha, encontram-se na Tabela 14 , podendo-se constatar que para estes caracteres, a população Entrelaçado x ESALQ-PB1 (EE) apresentou os valores mais elevados, ficando a população ESALQ-PB1 (E) com valores intermediários, e a Cravo x ESALQPB1 com os valores médios mais baixos.

os valores médios apresentados pela testemunha, 215,33 (cm/planta), 121,66 (cm/planta) e 21,47 (nọ ra mificações/planta), respectivamente, para AP, AE e NRP, fica 
ram bem pröximos aos apresentados pela população ESALQ-PB1 pa ra AP e AE, sendo que para NRP este valor ficou mais próximo ao obtido para a população Cravo x ESALQ-PB1.

As Figuras 7,8 e 9 mostram a distribuição das médias de altura da planta, altura da espiga e número de ramificações do pendão para as três populações, podendo-se observar os segregantes transgressivos em relação à população ESALQ-PB 1 .

Os valores e significāncias dos quadrados médios obtidos nas anälises de variância para altura de planta, altura de espiga e nümero de ramificaçóes do pendão podem ser vistos nas Tabelas 29,30 e 31 , podendo-se constatar que para todas as populações e caracteres, os quadrados médios foram significativos para a variação entre familias de meios irmãos.

Os coeficientes de variação experimental para a 1 tura de planta fora $6,57 \% ; 5,74 \%$ e $5,68 \%$, enquanto que para a 1 tura de espiga foram $8,22 \%$; $7,17 \%$ e $7,13 \%$, respectiva mente, para as populações E, EC e EE.

Para o nümero de ramificações do pendão, as es timativas dos coeficientes de variação experimental para as populações E, EC e EE foram, respectivamente, 13,80\%, $13,47 \%$ e $11,89 \%$.

\subsubsection{Estimativas de paràmetros genëticos}

Para cada uma das populações, as estimativas das variâncias genéticas para altura d planta e altura d espiga encontram-se na Tabela 37 , enquanto que para nümero 
de ramificações do pendão estas estimativas são mostradas na Tabela 38 .

As estimativas das variâncias genéticas adití vas para altura da planta foram 217,7728;163,1908 e 257,2944 (cm/planta $)^{2}$ sendo que para altura de espiga estas estimativas foram 119,$3132 ; 73,2720$ e 88,4240 (cm/planta) ${ }^{2}$, correspondendo, respectivamente, às populações E, EC e EE.

os valores encontrados para as estimativas dos coeficientes de herdabilidade no sentido restrito ao nivel de plantas individuais foram 42,88\%; 40,50\% e 51,90\% para altura de planta, e 40,21\%; $31,97 \%$ e $31,42 \%$ para altura de espiga, que são pertencentes, respectivamente, às populações E, EC e EE.

Ao nível de médias de progēnies, as estimativas dos coeficientes de herdabilidade para as populaçóes E, EC e EE foram 44,33\%; 46,55\% e 52,76\% para altura da planta, e $46,37 \% ; 44,57 \%$ e $43,25 \%$ para altura da espiga.

Considerando-se o caräter nümero de ramificações do pendão, as estimativas das variáncias genéticas aditivas para as populações E, EC e EE foram, respectivamente, 27,9896x $10^{-2} ; 22,3812 \times 10^{-2}$ e $36,5992 \times 10^{-2}$ (ramificaçós/planta) ${ }^{2}$.

As estimativas dos coeficientes de herdabilidade no sentido restrito ao nivel de plantas individuais foram $56,98 \% ; 48,17 \%$ e $62,56 \%$, e ao nivel de médias de progênies foram $65,69 \% ; 63,60 \%$ e $70,81 \%$, correspondentes às populações E, EC e EE e referentes ao nümero de ramificações do pendão.

As Tabelas 41 e 42 mostram as estimativas dos progressos esperados por ciclo, utilizando-se da seleção en- 
tre e dentro de familias de meios irmãos com sementes rema nescentes (SEDFMI) e da seleção massal em ambos os sexos (SM), para cada uma das populações e para os caracters altura da planta, altura da espiga e nümero de ramificações do pendão .

Pode-se verificar que as estimativas dos progressos esperados por ciclo com SEDFMI foram 12,13; 12,57 e 17,59 centimetros por planta para altura da planta, corres pondentes às populações E, EC e EE e equivalentes em porcentagem a 5,57\%; 6,09\% e 7,61\%. Utilizando-se da SM, as estimativas destes progressos foram 17,00; 14,30 e 20,34 centime tros por planta para altura da planta, os quais correspondem a um ganho em porcentagem de $7,80 \%, 6,93 \%$ e $8,80 \%$, respectivamente, para as populaçöes E, EC e EE.

Para altura da espiga, as estimativas dos pro gressos genëticos esperados com SEDFMI das populações E, EC e EE, foram, respectivamente, 10,70; 7,66 e 8,31 centimetros por planta, enquanto que com a SM estes progressos esperados foram 12,18 (E); 8,56 (EC) e 9,28 (EE) centimetros por planta, correspondendo, respectivamente, em porcentagem a $9,85 \%$; $7,43 \%$ e $7,09 \%$.

Utilizando-se do processo SEDFMI, as estimati vas dos progressos genéticos esperados por ciclo para o carä ter nümero de ramificações do pendão e para as populações E, EC e EE foram 5,95; 5,00 e 7,06 ramificações por planta, equivalentes em porcentagem a $24,79 \% ; 21,74 \%$ e $24,96 \%$.

Quando foi considerado o processo de selecão massal em ambos os sexos, as estimativas dos progressos espe rados por ciclo para nümero de ramificaçoes do pendão e para as populações E, EC e EE foram 7,02; 5,77 e 8,42 ramificaçöes por planta, correspondentes em porcentagem a 29,26\%; 
$25,09 \%$ e $29,77 \%$.

As estimativas dos coeficientes de variação genética foram, em média, bastante similares para altura da planta $(3,40 \%)$ e altura da espiga (3,90\%) nas três populações, exceto para a populaşão E que apresentou 4,38\% para a 1 tura da espiga.

Com relação às estimativas dos indices de variação $\theta$, todas as populações apresentaram valores ao redor de 0,53 , tanto para altura da planta quanto para altura da espiga.

Valores mais ou menos similares foram também obtidos para nümero de ramificações do pendão nas três populaçóes, com referéncia às estimativas dos coeficientes de va riação genética e dos indices de variação $\theta$, sendo, respecti vamente, em média $10,66 \%$ e 0,82 .

4.3. Caracteres da espiga

\subsubsection{Anāi ise geral}

os valores médios obtidos para os caracteres comprimento da espiga (CE), nümero de grãos por fileira (NGF), nümero de fileiras por espiga (NFE), diàmetro da espiga ( $D E$ ) e diāmetro do sabugo (DS), referentes às três populações e à testemunha, encontram-se nas Tabelas 15 e 16 . Entre as popu 1 ações, pode-se averiguar que a população Cravo x ESALQ-PB1 apresentou os valores mais elevados para a maioria dos carac teres, exceto para comprimento de espiga e nümero de grãos por fileira, cujos valores médios mais altos foram obtidos, respectivamente, com as populações Entrelaçado x ESALQ-PB1 e ESALQ-PB 1 . 
as populaçós versus a testemunha, pode-se notar que a teste munha apresentou a média mais alta, para NGF $(37,38)$, que qualquer uma das populações, enquanto que situação inversa ocorreu para os caracteres NFE $(13,35)$ e praticamente, também, com DS $(2,79 \mathrm{~cm})$. No que diz respeito ao comprimento da espiga, o valor médio apresentado pela testemunha $(16,80$ cm) foi comparável ao da população E, superior ao da população EC e inferior à EE. Para diāmetro da espiga, o valor mé dio encontrado para a testemunha $(4,12 \mathrm{~cm} / e s p i g a)$ foi superior ao da população EE, e inferior ao da população EC e E.

As Figuras 10 a 14 exibem melhor a distribuição das médias para as três populações e, respectivamente, pa ra os caracteres CE, NGF, NFE, DE e DS, podendo-se observar os segregantes transgressivos em relaçã à populacão ESALQPB 1 .

os valores e significāncias dos quadrados mëdios obtidos nas anải ises de variāncia para os caracteres da espiga são mostrados nas Tabelas 32 a 36 , podendo-se verificar que para todos os caracteres e populaçoes, houve signifi cância para a variação entre familias de meios irmãos.

Considerando-se cada caracteristica "per se", as estimativas dos coeficientes de variaço experimental não foram discrepantes para as três populações, situando-se ao redor de 7,60\% para CE, 8,99\% para NGF, 5,80\% para NFE, 5, 20\% para DE e $4,97 \%$ para DS.

4.3.2. Estimativas de parāmetros genēticos

As estimativas das variāncias genéticas para 
o comprimento da espiga e para cada uma das populações, são mostradas na Tabela 38 , verificandorse os valores de $139,4436 \times 10^{-2} ; 96,2156 \times 10^{-2}$ e $191,6104 \times 10^{-2}$ (cm/espiga) ${ }^{2}$ para a variância genètica aditiva, respectivamente, para as populações E, EC e EE.

os valores encontrados para as estimativas dos coeficientes de herdabilidade no sentido restrito ao nivel de plantas individuais estiveram ao redor de $20 \%$, sendo o va lor mais elevado $28,02 \%$ para a população EE; ao nível de médias de progēnies, as estimativas para E e EC estiveram ao redor de 60\%, enquanto que para a população EE foi $70,81 \%$.

A Tabela 39 mostra as estimativas das variāncias genéticas, em (nọ grãos/fileira) ${ }^{2}$ e em (nọ fileiras/espiga ${ }^{2}$, para cada uma das populações e para os caracteres número de grãos por fileira (NGF) e nümero de fileiras por espiga (NFE), podendo-se perceber que para NFE, a estimativa da variância genética aditiva $\left(220,8668 \times 10^{-2}\right)$, da população Cravo x ESALQ-PBl (EC) foi quase duas vezes mais que a da população ESALQ-PB 1 (E), e 1,5 vezes superior à da popula ção Entrelaçado x ESALQ-PB 1 (EE).

Para o caräter NGF, o valor mais elevado da estimativa da variância genética aditiva, foi também obtido para a população EC $\left(1.074,1468 \times 10^{-2}\right)$, valor este bastante semelhante ao da população $E\left(1.048,8932 \times 10^{-2}\right)$, e 1,7 vezes superior ao da população EE $\left(617,5068 \times 10^{-2}\right)$.

No que diz respeito às estimativas dos coeficientes de herdabilidade no sentido restrito ao nivel de plantas individuais, os valores obtidos para NFE foram $41,40 \% ; 51,11 \%$ e $29,41 \%$, respectivamente, para E, EC e EE, sendo que para NGF estes valores ficaram compreendidos na faixa de 20 a $29 \%$ para as très populações. 
Ao nivel de médias de progênies, as estimativas dos coeficientes de herdabilidade para NFE ficaram ao re dor de $65 \%$ para as populações E e EC, sendo que para a popu1 ação EE o valor obtido foi 51,59\%; para NGF estas estimativas estiveram ao redor de $41 \%$ para as três populações, com uma baixa dispersão em torno deste valor.

Para o caràter diāmetro de espiga (DE) e diāmetrode sabugo (DS), a Tabela 40 evidencia as estimativas das variāncias genéticas obtidas para cada uma das populações, constatando-se que as variāncias genéticas aditivas mais elevadas foram obtidas com a população EE, sendo, respectivamente, $8,1400 \times 10^{-2}(\text { cm/espiga })^{2}$ e $49,9628 \times 10^{-3}$ (cm/sabugo $)^{2}$, enquanto que as populações E e EC mostraram, respectivamente, as estimativas mais baixas e intermediárias.

As estimativas dos coeficientes de herdabilidade no sentido restrito ao nivel de médias para o carätèr DE foram muito semelhantes para as populações E (54,55\%) e EE $(54,21 \%)$, sendo que a população EC apresentou o valor mais baixo $(42,27 \%)$; para DS, estas estimativas foram 44,88\%; $55,37 \%$ e $66,90 \%$, correspondentes às populações E, EC e EE.

Nas Tabelas 41 e 42 encontram-se as estimativas dos progressos genéticos esperados por ciclo, utilizando - se da seleção entre e dentro de familias de meios irmãos com sementes remanescentes (SEDFMI) e da seleção massal em ambos os sexos (SM), para cada uma das populações e para os caracte res CE, NGF e NFE, sendo que para DE e DS os progressos estí mados foram baseados apenas na seleção entre familias de meios irmãos.

Através destas tabelas, pode ser verificado que para CE e pa ra as populações E, EC e EE, os progoressos esperados com SEDFMI foram, respectivamente, 0,96;0,73 e 1,17 centimetros por espiga, os quais correspondem a um ganho em porcentagem 
a $5,59 \%, 4,51 \%$ e $8,13 \%$; com o uso da SM, as estimativas dos progressos foram 1,$03 ; 0,78$ e 1,30 centimetros por espiga, respectivamente para E, EC e EE, e correspondentes a um ganho em porcentagem a $5,99 \%, 4,82 \%$ e $9,03 \%$.

Considerando o caráter NGF, os progressos esperados por ciclo com SEDFMI foram 2,72; 2,84 e 1,87 grãos por fileira, correspondentes às populações E, EC e EE, e equivalentes em porcentagem a $7,74 \% ; 3,32 \%$ e $5,65 \%$; com o uso da SM, as estimativas destes progressos ficaram ao redor de 3,00 grãos por fileira para as populações E e EC, tendo a po pulação EE apresentado um ganho mais baixo.

Para NFE, as estimativas dos progressos com SEDFMI foram 0,56;0,86 e 0,52 fileiras por espiga, corres pondentes às populações E, EC e EE, e equivalentes em porcen tagem a um ganho de $4,00 \% ; 5,20 \%$ e $3,51 \%$; utilizando-se a SM, estas estimativas ultrapassaram em mais que duas vezes os valores obtidos com SEDFMI.

Utilizando-se a seleção entre familias de meios irmãos, as estimativas dos progressos genéticos para DE foram bastante similares para as trés populações, estando em torno de 0,12 centimetros por espiga; para DS as estimat vas foram 0,$21 ; 0,33$ e 0,40 centimetros por sabugo, respectí vamente, para as populações E, EC e EE, e equivalentes a um ganho em porcentagem de $7,18 \% ; 11,30 \%$ e $14,64 \%$.

Com relação às estimativas dos coeficientes de variação genética e dos indices de variação $\theta$, a população EE apresentou os valores mais altos $(4,03 \%$ e 0,52) para CE, ao passo que as populações E e EC apresentaram valores mais ou menos semelhantes.

Por outro lado, a população EC mostrou as es- 
timativas mais elevadas para os coeficientes de variação genética e para os indices de variação $\theta$, tanto para NGF (4,75\% e 0,53$)$ quanto para NFE $(5,02 \%$ e 0,77$)$, tendo as populaços E e EE apresentado estimativas mais ou menos semelhantes, p a ra cada um dos caracteres.

A população EE apresentou as maiores estimatí vas dos coeficientes de variação genética para DE $(3,56 \%)$ e DS $(4,04 \%)$, seguindo-se, em ordem decrescente, as populações EC e E. Para os indices de variação $\theta$, as populações E e EE mostraram estimativas semelhantes $(0,63$ e 0,62) para DE, sendo que a população EC apresentou um valor mais baixo $(0,49)$. Para DS, as estimativas dos indices de variação $\theta$ foram 0,$52 ; 0,64$ e 0,82 , respectivamente, para as populações E, EC e EE. 


\section{DisCuSSÃO}

5.1. Produção

Tem sido verificado, de um modo geral, que a maioria dos trabalhos encontrados na literatura engloba o termo produção para se referir aos caracteres peso de espigas ou peso de grãos. No entanto, no momento da discussão dos resultados, as estimativas dos parāmetros genéticos e fe notipicos são comparados indistintamente, desrespeitando-se a individualidade de cada caräter.

Em se tratando de comparações entre diferentes populações, com possiveis discrepāncias na relação peso de espigas: peso de grãos, julgou-se, então, necessärio discutir cada um dos caracteres separadamente, a fim de mostrar as diferenças de estimativas existentes entre eles, bem como para mostrar a conveniēncia de tal procedimento aos futuros trabalhos que envolvam comparaçoes desta natureza.

Torna-se necessärio salientar que, em decor rēncia do nümero de graus de liberdade (G.L.) do residuo ser relativamente elevado, foi desconsiderada a perda de 1 G.L. pelo ajuste da covariāncia, quando foi realizada a análise agrupada para peso da espiga e peso do grão. 
Convém também lembrar que, as médias obtidas para as diferentes populações e para todos os caracteres não sofreram ajuste para os efeitos ambientais entre experimentos, de forma que as diferenças entre médias apresentadas (Tabelas 11 a 16) contèm estes efeitos. Por outro lado, o comportamento das testemunhas nos diferentes experimentos foi bastante consistente, mostrando ser pequenas as diferenças ambientais entre estas.

\subsubsection{Avaliacão geral para peso de espigas \\ As médias do peso de espigas obtidas, nos dois} 1 ocais, para as populações ESALQ-PB1 (E), Cravo x ESALQ-PB1 (EE) e Entrelaçado $x$ ESALQ-PB 1 (EE) foram, respectivamente 6,34; 5,87 e 5,06 tha, as quais correspondem a $91,62 \%$; $84,82 \%$ e $73,12 \%$ em relação à mẻdia das testemunhas (Agroceres 401 e Cargil1 511). Tendo em vista que as testemunhas usadas foram hibridos comerciais, pode-se verificar a boa performance produtiva apresentada pelas populaçóes E e EC, enquanto que a população EE mostrou-se inferior.

Com relação à incorporação de genes dos germo plasmas exóticos Cravo e Entrelaçado na população adaptada ESALQ-PB1, verificou-se que, na média dos locais, houve uma influência negativa nas médias das populações semi-exóticas de $7,41 \%$ para EC e $20,19 \%$ para EE.

Sabendo-se que os efeitos imediatos de cruzamentos de germoplasmas exóticos $x$ adaptados têm sido desapon tadores (GALLINAT, 1977), estes decréscimos jä eram esperados, pois, além da, falta de adaptação das populaçóes semi-exóticas, somente duas recombinações foram realizadas, não ocorrendo a quebra de todos os blocos de ligação (HANSON, 1959 ; Wellhausen, 1965; Hallauer e Miranda FilHo, 1981 ).

Apesar deste decréscimo, a distribuição das médias (Figura 3 ) mostra a potencialidade genética das duas 
populações semi-exöticas, destacando-se, principalmente, a Cravo $x$ ESALQ-PB1. Estes resultados estão de acordo com os apresentados por GOODMAN (1965) e SHAUMAN (1971), onde também constataram que as médias das populações semi-exóticas foram afetadas negativamente pela incorporação de germoplasmas exóticos.

Os coeficientes de variação experimental obti dos da análise conjunta indicaram uma precisão experimental satisfatória, tendo em vista que nenhuma das três populaçoes mostrou valor superior a $15,5 \%$. Além do mais, estes valores se encontram abaixo da média de trinta trabalhos reportados por RAMALHO (1977), e podem ser considerados dentro dos 1 imi tes de boa precisão, para este tipo de experimentacão.

As significâncias dos quadrados médios (teste F) detectadas através das anālises de variância, tanto em ca da local quanto na anālise conjunta, mostraram a existência de variação entre famỉlias de meios irmãos para peso de espi gas nas três populaçōes. Isto fornece uma idéia do sucesso que poderáa ser obtido com a continuidade dos programas de me lhoramento, haja visto o potencial genético diferencial exis tente entre as familias avaliadas.

Quando foi realizada a análise conjunta, a população EC não exibiu significāncia para a interação trata mento x locais, mostrando não haver comportamento diferencial das familias nos dois ambientes. Por outro lado a população EE mostrou significância para a interação, podendo- se atribuir tal fato, principalmente, a uma diferença marcante do ambiente onde a raça Entrelaçadofoi coletada, e consequentemente uma farta de adaptação dos genótipos semi- exóticos às condições dos ambientes onde foram avaliados. 
5.1.2. Estimativas de parāmetros genëticos para peso de espigas

As magnitudes das estimativas das variâncias genéticas aditivas, em (g/planta), para as populações semi-exóticas EC e EE foram maiores que as da população adaptada nos dois locais $\left(\mathrm{L}_{1}: 290,5784 ; \mathrm{L}_{2}: 264,0376\right)$, exceto para a população EC no local 1. Pode-se verificar que esta superio ridade da população EE foi de aproximadamente 1,6 vezes em ambos os locais, enquanto que para a população EC foi de 1,1 vezes no local 2, sendo, no entanto, inferior em 1,9 vezes no local 1. Os trabalhos encontrados na literatura, para e $\underline{s}$ timativas de parâmetros genéticos em populações semi-exóticas, além de raros, apresentam, entre outros, o incoveniente de diferenças acentuadas entre as densidades populacionais, de ambientes e método de seleção utilizados, dificultando uma comparação mais precisa com os resultados obtidos. Mesmo assim, pode-se averiguar que os resultados obtidos no presente estudo mostraram-se coerentes com os apresentados por GOODMAN (1965) em dois locais, e com os relatados por SHAUMAN (1971), em duas densidades populacionais. A concordância marcante nestas comparações, é ofato de que as popu1 ações semi-exóticas apresentaram, de um modo geral, estimativas das variâncias genéticas aditivas mais altas que as po pulações adaptadas.

Por outro lado, para se ter uma idéia dos benefícios resultantes da incorporação de genes exóticos na po pulação adaptada, procurou-se comparar as estimativas das va riâncias genéticas aditivas das populações semi-exóticas EC e EE com estimativas obtidas em populações que foram avaliadas em um só local e na mesma densidade populacional do presente estudo. Assim sendo, pode-se averiguar que, em cada 
um dos locais, as estimativas das variâncias genéticas aditi vas da população semi-exótica EE foram maiores que as relatą das para diferentes populações (PATERNIANI, 1967 e 1968 ; ZIN LY, 1969; TORRES SEGOVIA, 1976; GERALDI, 1977 ; LIMA, 1977 ; SOUZA JUNIOR, 1983 ; AGUILAR MORĀN, 1984, entre outros); para a população EC, as estimativas das variâncias genēticas aditivas foram, na maioria das vezes e em relação às apresen tadas pelos autores acima citados, superiores no $10 c a 12$ e mais ou menos semelhantes no local 1 .

Levando-se em conta a anāiise conjunta, pode-se notar que as estimativas das variâncias genéticas aditivas, em (g/planta $)^{2}$, das populações EC $(186,1600)$ e EE (223,0180) foram superiores, respectivamente, em 1,85 e 2,82 vezes em relação à estimativa da população adaptada E (100,4820), confirmando-se o aumento da variabilidade genétí ca decorrente da incorporação de genes dos germoplasmas exóticos na população adaptada.

Comparando-se as estimativas das variâncias geñéticas aditivas obtidas para cada população e em cada um dos locais com as estimativas da análise conjunta, pode-se observar que as estimativas resultantes da análise conjunta foram inferiores em mais de $50 \%$ que as estimativas apresenta das para cada um dos locais. Tal fato já era esperado, uma vez que em experimentos conduzidos em apenas um local, o componente resultante da interação genótipo por ambiente não poder ser isolado (GARDNER, 1963). Resultados desta natureza também foram evidenciados para a população semi-exótica Krug x Tabloncillo (KT) e para a populaça a testemunha (SHAUMAN, "1971), onde foram verificados decréscimos nas estimativas das variàncias genéticas aditivas nas anảises combinadas, prevalecendo, porëm, a maior potencialidade 
genètica da população semi-exötica.

As estimativas dos coeficientes de herdabilidade no sentido restrito ao nivel de plantas foram maiores no local 2, obtendo-se os valores mais elevados, em ambos os 1 o cais, para a população EE.

Quando foi considerada a anālise conjunta, estas estimativas foram 4,28\% para a população E, 7,8 $8 \%$ para EC e $15,52 \%$ para EE. Pode-se, então, averiguar que as populações semi-exóticas exibiram valores 1,84 e 3,62 vezes mais elevados que a população adaptada, indicando a potencialidade genética da introgressão destas raças para o melhoramento do peso de espigas.

Ao nîvel de médias de progênies, as estimativas dos coeficientes de herdabilidade também foram maiores no local 2, sendo os mais altos valores para a população EE. $\mathrm{Na}$ anālise conjunta, as populações EC $(44,23 \%)$ e EE $(54,00 \%)$ mostraram-se, respectivamente, 1,67 e 2,05 vezes superiores à população E $(26,37 \%)$ para as estimativas dos coeficientes de herdabilidade, demonstrando mais uma vez a potencialidade das raças exóticas.

Infelizmente não se dispõem de dados na literatura que sejam comparáveis diretamente com as estimativas dos coeficientes de herdabilidade obtidos para as populações semi-exōticas, mas, pode-se verificar que as estimativas obtidas se enquadram dentro da classificação proposta por HALLAUER e MIRANDA FILHO (1981), para coeficientes de herdabili dade ao nịvel de médias de parcelas.

Efetuando-se, entretanto, comparações com populações já adap tadas e avaliadas no Departamento de Genética, percebe-se que para as populações semi-exöticas, principalmente EE, as esti 
mativas dos coeficientes de herdabilidade ao nível de plantas foram superiores à média das estimativas citadas por RAMALHO (1977), MIRANDA FILHO (1977 e 1979), CRISÓSTOMO (1978), SAWAZAKI (1979), SOUZA JUNIOR (1983) e AGUILAR MORĀN (1984), entre outros.

Considerando que, de um modo geral, as variações ambientais foram predominantes na variação fenotípica total do peso de espigas, pode-se notar a existência da magnitude elevada da variância genética aditiva que poderá ser explorada com as populações semi-exōticas, uma vez que os coeficientes de herdabilidade obtidos foram relativamente a 1 tos, em relação aos encontrados na literatura.

Em cada um dos locais, as estimativas dos pro gressos genéticos esperados para as populações semi-exóticas EC e EE foram mais elevadas que as estimativas obtidas para a população adaptada E, quer seja através do processo de seleção entre e dentro de famílias de meios irmãos com sementes remanescentes (SEDFMI) ou através da seleção massal em ambos os sexos (SM). A ünica exceção observada foi para a população EC no local. 1, em qualquer um dos esquemas utiliza dos .

Estes resultados foram concordantes com os en contrados por GOODMAN (1965) e SHAUMAN (1971), que também en contraram progressos genéticos mais altos, com seleção massal, para as populações semi-exóticas avaliadas, respectivamente, em duas localidades e em duas diferentes densidades populacionais.

$\widehat{E}$ interessante destacar que, pensando-se em fazer seleção em mais de um ambiente, as estimativas obtidas 
para cada local estão superestimadas, uma vez que ocorre a interação da variāncia genẻtica aditiva com local. Deste mo do, o progresso estimado em mais de um local será bem mais baixo que a estimativa do progresso esperado para cada 1ocal. No presente estudo, tomou-se como exemplo ilustrativo a população adaptada E no local 1 com o mëtodo SEDFMI, onde - progresso genético esperado para o próximo ciclo será de $11,16 \mathrm{~g} / \mathrm{planta.}$ Supondo-se, no entanto, que a seleção fôsse em dois locais, o progresso genético esperado seria $3,3 \mathrm{~g} /$ planta, ou seja, $70 \%$ mais baixo que o progresso estimado para o local 1 .

Apesar de não existirem dados que possam ser comparāveis com as populaçöes semi-exöticas, os resultados obtidos no Departamento de Genética com a seleção entre e dentro de familias de meios irmäos forneceram uma boa indica ção do potencial genético das populações resultantes dos cru zamentos com as raças exóticas Cravo e Entrelaçado. Assim sendo, verificou-se que as estimativas dos progressos genétí cos esperados com SEDFMI e SM nas populações semi-exóticas, principalmente EE, foram superiores às estimativas obtidas em um 1ocal, conforme relataram PATERNIANI (1968), Z INSLY (1969), MOTA (1974), CUNHA (1976), GERALDI (1977), MIRANDA FILHO (1977 e 1979), SOUZA JUNIOR (1983) e AGUILAR MORÅN (1984), entre outros.

Levando em consideração a anālise conjunta, os progressos esperados por ciclo para as populações E, EC e EE com o uso de SEDFMI foram, respectivamente, 3,00\%; 7,70\% e $13,25 \%$, verificando-se que as estimativas das populações semi-exóticas foram 1,93 e 3,32 vezes mais a1tas que a estimativa da população adaptada. Por outro lado, com a SM estas estimativas foram 2,00 (EC) e 4,00 (EE) vezes superiores 
à estimativa do progresso esperado com a população adaptada $(2,93 \%)$. Convém lembrar que com SM em ambos os locais, as estimativas dos progressos genéticos esperados foram obtidas atravës da média dos dois locais, considerando que em cada local a variância genética aditiva estava livre da interação por local e que foi aplicada a mesma intensidade de seleção.

Comparando-se as estimativas dos progressos es perados das populações semi-exöticas com as estimativas da população adaptada, percebe-se de imediato a potencialidade das populações resultantes dos cruzamentos com as duas raças exóticas. No entanto, deve-se lembrar que as médias das populações EC e EE foram 7,40\% e 20,20\% inferiores em relação à média da população adaptada, mas, superiores em $85,27 \%$ e $181,66 \%$ nas estimativas das 7 ariâncias genéticas aditivas. Assim sendo, assumindo-se uma constância da variância genéti ca aditiva da população adaptada e uma queda de 30\% na varia bilidade genética das populaçóes semi-exöticas, com três ciclos de SEDFM ou quatro ciclos de SM, a média das populaçöes semi-exöticas atingiräo valores superiores à média da população adaptada, além de permanecerem com as variâncias genéticas aditivas mais altas.

A variabilidade genētica das populações E, EC e EE, estimada através dos coeficientes de variação genética e dos İndices de variação $\theta$, indicou, de um modo geral, que as populações semi-exóticas foram também superiores em relação à população adaptada para ambos os parâmetros, destacandose, principalmente, a população EE. 


\subsubsection{Avaliação geral para peso de grãos}

As médias obtidas para peso de grãos, nos dois locais, foram aproximadamente, 5,00 t/ha para a população E, 4,74 t/ha para a população EC e 4,00 t/ha para a população EE, correspondentes, respectivamente, a $88,74 \% ; \quad 84,30 \%$ e $71,13 \%$ à média das testemunhas. Em relação ao peso de espigas, pode-se observar que o peso de grãos mostrou uma redução de aproximadamente $20 \%$, para cada uma das populações.

Comparando-se as médias obtidas das populações semi-exóticas EC e EE versus a média da população adaptada E, percebe-se o potencial genético destas populações, principalmente da EC, uma vez que estão em fase inicial de mel horamento.

Por outro lado, a incorporação de genes dos germoplasmas exóticos Cravo e Entrelaçado na população adaptada ESALQ-PBl teve uma influência negativa na média das populações semi-exóticas resultantes do cruzamento, sendo estes decréscimos de 5,0\% para EC e $20 \%$ para EE, o que é concordante com os resultados obtidos em populações semi-exóticas trabalhadas por SHAUMAN (1971), HALLAUER (1978) e, atê o segundo ciclo de seleção com MOLL e SMITH (1981).

Observando-se a distribuição das médias destas populações semi-exóticas nos dois locais (Figura 6), pode ser notado que a população EC teve um comportamento mais ou menos semelhante ao da população adaptada, enquanto que a curva de distribuição das médias da população EE foi bem inferior à das outras populações. Se, entretanto, for levado em consideração que as populações semi-exóticas possuem 
maior variabilidade genética, espera-se que as médias destas populações excedam ou se equivalham à média da população adaptada, após dois ciclos de seleção.

Considerando a falta de adaptação das populações semi-exóticas e o fato de que somente foram efetuadas duas recombinações, estes resultados não são desencorajadores, uma vez que segregantes transgressivos potencialmente desejáveis deverão ocorrer após a quarta ou quinta recombinação (HANSON, 1959), aumentando, consequentemente, a mëdia das populações semi-exóticas (LONNQUIST, 1974; SHEATA e DRAWN, 1975; HALLAUER e MIRANDA FILHO, 1981). Por outro 1ado, LONNQUIST (1978), lembrou que é necessārio tempo e paciência quando se trabalha com germoplasma exótico. Isto po de ser constatado nos resultados conseguidos por EBERHART (1971) e GENTER (1976), onde verificaram aumentos nas produções de populações semi-exóticas, após dez a vinte ciclos de se 1 eção.

A precisão experimental dos ensaios foi consi derada dentro dos 1 imites esperados, tendo em vista que os coeficientes de variação experimental estiveram, em média, ao redor de $16 \%$ para as três populações, valores estes inferiores aos encontrados por SHAUMAN (1971) para uma população semi-exötica na densidade populacional equivalente à utiliza da no presente estudo.

Os valores e significâncias dos quadrados mëdios (teste F) encontrados, tanto na análise de cada local quanto na anälise conjunta, indicaram a presença de variação entre familitias de meios irmãos para peso de grãos nas três populações. 
Quanto à interação tratamentos $x$ locais, observou-se o mesmo padräo de resposta que foi obtido para peso de espigas; desta forma, foi verificado a não significância da interação para a população EC, enquanto que as popula ৎöes E e EE mostraram significância a $1 \%$, indicando um comportamento diferencial dos genötipos avaliados nos dois ambientes.

\subsubsection{Estimativas de parāmetros genéticos para peso de grãos}

Considerando as estimativas das variâncias ge néticas aditivas, em (g/planta) ${ }^{2}$, obtidas em cada um dos $10-$ cais, percebe-se que as populações semi-exóticas EC e EE mos traram, de um modo geral, maior variabilidade genética que a população adaptada E ( $\left.L_{1}: 208,6664 \mathrm{e} \mathrm{L}_{2}: 159,3520\right)$, exceto a população EC no local 1. A superioridade da população EE foi de aproximadamente 1,60 e 2,10 vezes, respectivamente, para o local 1 e 2 , enquanto que para a população EC foi 1,60 vezes no $10 \mathrm{cal} 2$, sendo, por ëm, inferior 1,90 vezes no local 1. Pode-se, então, notar que a introgressão foi benéfica para aumento da diversidade genética, haja visto que as populações semi-exóticas mostraram estimativas das variâncias genéticas aditivas superiores em relação à população ad a ptada.

SHAUMAN (1971) tambēm econtrou resultados semelhantes aos ob tidos no presenté estudo, uma vez que a populaçäo semi-exótí ca KT exibiu em um local, estimativas da variância genética aditiva mais altas, tanto na densidade populacional baixa quanto na alta. Se, grosseiramente, forem efetuadas compara ções entre as estimativas das variâncias genēticas aditivas encontradas no presente estudo com a estimativa da densidade 
populacional alta (SHAUMAN, 1971), pode-se verificar que, de um modo geral, as estimativas das populações semi-exóticas EC e EE foram maiores, destacando-se, principalmente, a popu laçäo EE.

Efetuando-se a anālise conjunta, confirmou-se mais uma vez a superioridade das populações semi-exóticas, tendo em vista que as estimativas das variâncias genéticas aditivas foram 82,$5580 ; 117,5000$ e 201,5452 , respectivamente, para as populações E, EC e EE. O decréscimo destas esti mativas, em relaçäo às obtidas para cada um dos locais, já era esperado (GARDNER, 1963), sendo também mostrado por SHAU MAN (1971) com os resultados da análise combinada.

Resultados experimentais sobre a potencialida de de populações semi-exóticas foram mostrados por SUBANDI e COMPTON (1.974), MOLL e SMITH (1981), onde evidenciaram a pre sença da maior variabilidade genética como sendo aditiva e as amplas possibilidades de sucesso com a seleção. Moll e SMITH (1981), por exemplo, obtiveram, após cinco ciclos de seleção, uma estimativa de 728,50 (g/planta) ${ }^{2}$ para a variância genética aditiva da população semi-exótica Indian chief $x$ Diente de Caballo, que sendo comparada com a estimativa $(222,20)$ da populaçäo adaptada Indian Chief (MOLL e ROBINSON, 1966), vem demonstrar a considerável superioridade da população semi-exötica.

Apesar de as diferenças entre as densidades populacionais da literatura americana e a utilizada no presente estudo, comparou-se as estimativas das variâncias genéticas aditivas das populaçöes EC e EE com estimativas resultan tes de análises combinadas e para populações adaptadas (MOLL et alii, 1960; EBERLART et ali i, 1966; EL-ROUBY et alii, 
1973; GALAL et ali $i$, 1974; OBILANA e HALLAUER, 1974, entre outros). Observou-se que as estimativas das variâncias gené ticas aditivas das populações EC e EE foram superiores ou equivalentes às apresentadas pelos autores acima citados. Estas comparações, apesar de empirricas, ressaltam os efeitos positivos resultantes da incorporação de genes dos germoplas mas exóticos na população adaptada.

Utilizando-se da seleção massal, foram observados resultados mais promissores, para aumento da produção, em populações semi-exóticas do que em populações adaptadas (WELlHAUSEN, 1965; GENTER, 1976 ; COMPTON et ali $i$, 1979; HANSON e JOHNSON, 1981), aliando-se o fato do melhoramento obti do para outros atributos agronômicos. GENTER (1976), por exemplo, relatou um ganho de $171 \%$ para peso de grãos em um composto formado a partir do cruzamento de vinte e cinco raças, verificando ainda que houve uma redução para a altura da planta e da espiga.

Torna-se, então, evidente que a incorporação de genes exóticos tem sido benëfica para aumento da variabi-

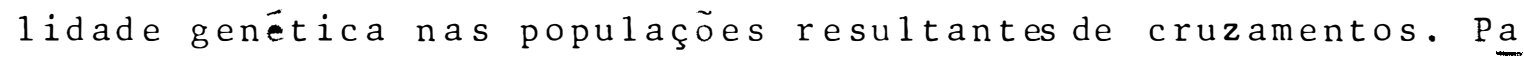
ra esta incorporação, o procedimento mais usual (HALlauer, 1978 ) é a realização de cruzamento entre as populações exótí ca e adaptada, optando-se, posteriormente, pelo esquema de seleção e nümero de recombinações, dependendo do objetivo do trabalho. Um ponto que tem sido questionado, é o porcentual de genes exōticos que deve ser incorporados. Recomendações têm sido feitas para a introgressão de $25 \%$ ou $50 \%$ (GRIFFING e LINDSTROM, 1954; WELLHAUSEN, 1965). No entanto, HALLAUER (1978) verificou que estas proporções relativas de $25 \%$ e $50 \%$ não foram consistentes nos dois anos em que fez ensaios de avaliação, não se podendo chegar à uma conclusão. 
Assim sendo, comparações crüticas sô poderão ser feitas após estudos adicionais (HALLAUER e MIRANDA FILHO, 1981).

Em cada um dos locais, as estimativas dos coe ficientes de herdabilidade no sentido restrito ao nivel de plantas e ao nível de médias de progênies foram maiores para as populações semi-exöticas, exceção feita para a população semi-exötica EC no 1 ocal 1.

Levando em consideração a anālise conjunta, as estimativas obtidas para os coeficientes de herdabilidade ao nível de plantas individuais foram, respectivamente 1,48 (EC) e 3,04 (EE) vezes maiores que a estimativa da população adaptada $(5,08)$. Esta superioridade foi também observada ao nível de médias de progênies, uma vez que as populações EC e EE foram, respectivamente, maiores em 1,40 e 1,76 vezes em relação à estimativa da populąão adaptada $(30,13 \%)$.

Tendo em vista que HALlAUER e MIRANDA FILHO (1981) apresentaram as médias de diversas estimativas para os coeficientes de herdabilidade ao nível de parcelas, compa rações com as estimativas obtidas no presente estudo não tem, praticamente, validade. Mesmo assim, para se ter uma idéia geral da potencialidade genética das populações semi-exöticas, verificou-se, de um modo geral, que as estimativas dos coeficientes de herdabilidade ao nível de plantas em cada local, foram superiores às estimativas apresentadas para compostos, variedades de polinização aberta e variedades resultantes de cruzamentos.

Segundo o levantamento efetuado por HALLAUER e MIRANDA FILHO (1981 p. 118), as estimativas dos coeficientes de herdabilidade para peso de grãos foram menores que $30 \%$, havendo, assim, uma concordância com os resultados aqui 
obtidos.

Com relação aos progressos genéticos esperados, tanto com SEDFMI quanto com SM, foi observado que em ca da um dos locais as populações semi-exóticas EC e EE mostraram valores mais altos que a população adaptada, exceto para a população EC no local 1. Resultados similares foram verificados por SHAUMAN (1971), que utilizou duas densidades populacionais em um ano, e por HALlAUER (1978) em dois diferen tes anos, que usou populações semi-exóticas com diferentes porcentuais de genes incorporados.

Desta forma, as estimativas dos progressos ge néticos esperados para as populações semi-exóticas mostraram, de um modo geral, uma maior potencialidade que a popula ção adaptada, dentro de cada local. Deve-se lembrar, entretanto, que se for praticada stelęäo em mais de um local, as estimativas destes progressos estäo superestimadas devido à interação da variância genética aditiva x local. Tomando-se, por exemplo, a variância genética aditiva do local 1 pa ra: a população EE $(324,2884)$, verifica-se que hà uma redução de $38 \%$ na variância genética aditiva obtida da anảise conjunta, uma vez que é isolado o efeito de local. Assim sendo, o progresso genético esperado para a população EE no local 1 (15,27 g/planta), será $8,96 \mathrm{~g} / \mathrm{planta}$ quando os resul tados forem extrapolados para mais de um ambiente.

Quando foi realizada a anālise conjunta, observou-se que as estimativas dos progressos esperados por ciㅡ c10 com SEDFMI foram 4,93; 7,03 e 11,25 gramas por planta, respectivamente, para as populações E, EC e EE, verificando-se que as populações semi-exóticas foram 1,42 (EC) e 2,28 (EE) vezes mais elevadas que a estimativa da população adap- 
tada. Utilizando-se da SM, estas estimativas foram 1,42 $(E C)$ e 2,57 (EE) vezes mais a 1 tas que a estimativa do progresso genético esperado com a população adaptada (3,88 g/ planta), resultados estes que estão de acordo com o maior ga nho por ciclo encontrado para populações semi-exóticas do que para populações testemunhas, conforme mencionaram SHAUMAN (1971) e HALlaUER (1978).

$\bar{E}$ necessärio lembrar que as estimativas dos progressos genéticos esperados com SM mencionadas na Tabela 28, foram obtidas através da média dos dois locais, considerando que a variância genética aditiva estava livre do efeito de local e que foi praticada a mesma intensidade de seleção em ambos os locais. Isto se deve ao fato de que efetuan do-se seleção massal de plantas em um local, não se tem certeza de que as mesmas plantas serão selecionadas no outro 1 o cal. Daí, há a necessidade de se isolar o efeito de local na variāncia genética aditiva da análise conjunta, a fim de tornar mais realistica a estimativa do progresso com selesão massal para mais de um ambiente.

Em qualquer um dos esquemas de melhoramento utilizados, verificou-se a potencialidade das populações semi-exóticas quanto às estimativas dos progressos genéticos esperados, em relação à população adaptada. Convém lembrar, no entanto, que as médias das populações EC e EE foram 5,00\% e 20\% inferiores à. média da população adaptada (Tabela 13), mas, superiores em 42,32\% (EC) e $144,12 \%$ (EE) nas estimativas das variâncias genéticas aditivas (Tabela 25). Supondo- se, então, que as estimativas das variâncias genéticas aditivas das três populações permaneçam constantes, ou, mesmo que ocorram reduções de $25 \%$ a $30 \%$ nas estimativas das popula ções semi-exóticas, tal como relatou MOLL e SMITH (1981), po de-se verificar que com três ciclos de SEDFMI, as médias das 
.89 .

populações semi-exōticas serão equivalentes ou maiores que a média da população adaptada, além das variâncias genéticas aditivas das populações semi-exöticas permanecerem mais altas.

As estimativas dos coeficientes de variação genética para as populações EC e EE foram, respectivamente, 1,25 e 1,94 vezes maiores que a da população adaptada, enquanto que para os indices de variação $\theta$ esta superioridade foi de 1,12 (EC) e 1,77 (EE) vezes, estando de acordo com os resultados averiguados por SHAUMAN (1971) para a população semi-exótica KT.

Fazendo-se uma retrospectiva geral para os pa râmetros genéticos obtidos para peso de grãos, tanto as evidências diretas quanto indiretas foram indicativas da predominância da variabilidade genética das populações semi-exóticas EC e EE em relação à população adaptada, mostrando o potencial genético das raças Cravo e Entrelaçado para a incorporação de genes.

5.2. Caracteres da planta

$$
\begin{aligned}
& \text { 5.2.1. Avaliação geral para altura da planta e da es } \\
& \text { piga }
\end{aligned}
$$

As mẻdias obtidas para a população semi-exóti ca EC foram inferiores à média das testemunhas e à média da população adaptada, tanto para altura da planta (AP) quanto para altura da espiga (AE); no entanto, para a população semi-exötica EE ocorreu o inverso, o que foi coerente com os resultados relatados por GOODMAN (1965) e SHAUMAN (1971) pa- 
ra populações derivadas de cruzamentos com germoplasmas exöticos.

Apesar de a populaçáo EE ter mostrado médias mais a 1 tas de AP e AE (em torno de 6\%) que a população adaptada, pode-se constatar que estes valores foram, em média, $15,8 \%$ mais baixos que a média apresentada pela raça exótica Entrelaçado (Tabela 8), conforme mencionaram PATERNIANI e GOODMAN (1977).

Para a população adaptada, as médias de AP e AE foram inferiores às médias apresentadas por MIRANDA FILHO (1978), GHINI e MIRANDA FILHO (1979), fato este que pode ser devido a diversos fatores, mas, sem düvida, o mais importante é o efeito direto do ambiente na expressão daqueles carac teres. De qualquer forma, pode-se inferir o beneficio resul tante da incorporação de genes do germoplasma exótico Cravo na população adaptada, uma vez que a populaçáo semi-exótica EC apresentou médias mais baixas de AP e AE, tanto em relação à população adaptada quanto em relação à raça original Cravo (Tabela 8 ).

Resultados desta natureza também foram verifi cados por VERA e CRANE (1970), HALLAUER e SEARS TROYER e BROWN (1972) e GENTER (1976), onde constataram a maior potencialidade das populações semi-exóticas para exibirem portes mais baixos de AP e AE que as populaçóes adap tadas .

Observando-se, por outro lado, a distribuição das médias de AP e AE das três populações (Figuras 7 e 8), constata-se que as populações semi-exóticas EC e EE apresentaram uma maior amplitude de variação que a população adapta 
da, destacando-se os segregantes transgressivos que poderão ser selecionados e a maior concentração de familias com AP e AE mais reduzidas que a população adaptada. Estes resultados são animadores, uma vez que mostram a potencialidade genëtica de selecionar plantas com altura e inserção de espigas mais baixas, fazendo uso de poligenes (MIRANDA FILHo, 1974 ).

A precisão experimental dos ensaios pode ser considerada como boa, tendo em vista que os coeficientes de variação experimental para AP das populações EC e EE ficaram abaixo da média $(5,98 \%)$ de dezesseis estimativas obtidas no Departamento de Genética (Tabela 3), sendo que a população E apresentou um valor mais elevado $(6,57 \%)$. Para AE, os coef cientes de variação experimental obtidos para as três popula ções foram inferiores à média $(8,43 \%)$ destas dezesseis estimativas, mostrando, assim, a boa precisão dos experimentos.

As significâncias dos quadrados médios (teste F) detectadas, tanto para altura da planta quanto para altura da espiga, constituem-se em fortes indicadores das possibilidades de sucesso com seleção, principalmente com as popu 1 ações semi-exöticas EC e EE, haja visto os segregantes transgressivos (Figuras 7 e 8) que poderão ser escolhidos pa ra obtenção de plantas com arquiteturas mais baixas.

5.2.2. Estimativas de parāmetros genēticos para altu ra da planta e da espiga

Antes de qualquer comparação ou discussão de resultados, é necessärio lembrar que a raça Cravo tem sido mantida na região sul do Brasil, sem muita introgressão com 
outras raças ou cultivares (PATERNIANI e GOODMAN, 1977). As sim sendo, pressupõe-se que alguma forma de seleção tenha sí do praticada no sentido de escolher plantas com atributos agronômicos desejāveis.

Verificando-se as estimativas das variâncias genéticas aditivas de AP e AE, pode-se observar que a popula ção semi-exótica EC mostrou valores mais baixos que a popula ção adaptada E, resultados estes que foram coerentes com os apresentados por SHAUMAN (1971). Por outro lado, a estimati va da variância genética aditiva de AP foi mais alta para a população EE que para a população adaptada, ocorrendo o inverso para AE. Efeitos similares foram observados por GOODMAN (1965) para a população semi-exótica West Indian Composi te (WIC), em relação a uma população adaptada do "Corn Belt".

Levando em consideração a origem da raça Cravo e supondo que alguma seleção tenha sido praticada, é de se esperar que a população EC não tenha exibido tanta variabilidade genética, tal como ocorreu com a população EE, tendo em vista ser a raça Entrelaçado de origem indígena, e não ter sido submetida à seleção para estes atributos agronômicos.

Inúmeros trabalhos da literatura americana (Tabela 1) têm mostrado estimativas de variâncias genéticas aditivas, em (cm/planta) ${ }^{2}$, para AP e AE, podendo-se verificar que as estimativas estiveram compreendidas numa faixa de 63 a 641 para AP, e 105 a 843 para AE. Por outro 1ado, HALLAUER e MIRANDA FILHO (1981) realizaram um levantamento de 45 e 52 trabalhos, respectivamente, para AP e AE, e mostraram a média das estimativas das variâncias genéticas aditivas $(212,9$ e 152,7$)$. Uma vez que a maioria destas estimati- 
vas foram obtidas de análises combinadas, comparações com as estimativas do presente estudo ficam superestimadas. Mesmo assim, pode-se averiguar que para AP, as estimativas obtidas para as populações semi-exóticas e adaptada ficaram intermediárias, enquanto que para $A E$ as populações semi-exóticas apresentaram valores mais baixos.

$$
\text { Para estes caracteres, comparações mais }
$$
realisticas podem ser realizadas com as estimativas relacionadas em dezesseis trabalhos (Tabela 2) que foram conduzidos no Departamento de Genética, em apenas um local ou durante um ano. Assim sendo, constata-se que as estimativas das variâncias genéticas aditivas para AP e AE encontram-se dentro da amplitude de variação, tanto para as populações semi-exóticas quanto para a população adaptada.

As estimativas obtidas para os coeficientes de herdabilidade no sentido restrito ao nível de plantas e ao nível de médias de progênies mostraram que os valores mais altos para AP foram conseguidos com a população semi-exótica EE, tendo as populações E e EC apresentado valores da mesma magnitude para este caräter; para AE, as magnitudes dos coeficientes de herdabilidade ao nivel de plantas e ao nível de médias foram mais ou menos semelhantes, tanto para a população adaptada quanto para as populações semi-exóticas.

Considerando por outro lado, a faixa de varia ção (30\% a 50\%) para as estimativas dos coeficientes de herdabilidade, ao nível de médias de parcelas, conforme propuseram HALLAUER e MIRANDA FILHO (1981), verifica-se que as estí mativas obtidas para os coeficientes de herdabilidade ao nível de plantas estão dentro desta amplitude de variação. 
Observando as estimativas dos progressos gené ticos esperados para as três populações e comparando-se com as estimativas médias de AP $(6,84 \%)$ e AE $(9,94 \%)$ obtidas em trabalhos conduzidos no Departamento de Genética com SEDFMI (Tabela 2), constatou-se que os resultados nãoforam muito discrepantes, evidenciando-se variabilidade genética capaz de se conseguir progressos para reduzir o porte das plantas nas três populações.

Verificou-se, por outro lado, que os valores obtidos para os progressos genéticos esperados de AP e AE fo ram maiores com SM do que com SEDFMI, e que as três populações mostraram valores mais ou menos semelhantes, indicando ser a seleção massal mais eficiente. Isto foi mostrado para populações exóticas e semi-exóticas (VERA e CRANE, 1970; HAL LAUER e SEARS, 1972), tendo em vista que ganhos entre 4,5\% e $15 \%$ foram conseguidos com a seleção massal.

Segundo GERALDI (1977), HALLAUER e MIRANDA FILHO (1981) e SOUZA JUNIOR (1983), entre outros, estes caracteres apresentam uma herdabilidade relativamente alta, indicando que boa parte da variação fenotípica total existente é atribuida à variância genética aditiva. Tal fato foi comprovado no presente estudo, acreditando-se que progressos possam ser obtidos para reduzir a altura da planta e da espiga, com esquemas mais simples de seleção.

Os valores para os coeficientes de variação genética foram bastante similares para AP nas três populações (em média $3,40 \%$ ), enquanto que para os indices de varia ção $\theta$ foram bem semelhantes para as populações E e EC $(0,53)$, sendo um pouco maior $(0,61)$ para a população EE. Para a característica AE, os coeficientes de variação genética das po pulações EC e EE foram um pouco inferiores ao da população E 
$(4,38 \%)$, sendo que para os indices de variaça $\theta$ os valores foram muito semelhantes (em torno de 0,52), para as trés populações.

Observou-se, de um modo geral, que as presenças dos germoplasmas exóticos Cravo e Entrelaçado na população adaptada não influenciaram consistentemente nas estimati vas dos parāmetros genéticos das populações semi-exóticas pạ ra estes dois caracteres mas, os efeitos benéficos foram comprovados no sentido de reduzir a média.

\subsubsection{Avaliasão geral para nümero de ramificações do pendão}

Considerando o caráter número de ramificações do pendão (NRF), as médias das populações E, EC e EE foram, respectivamente, $11,98 \% ; 7,13 \%$ e $31,72 \%$ mais altas que a média das testemunhas (21,47 ramificaçós por planta).

(24,00 ramificaçoes/planta), valor este superior ao encontra do por ANDRADE e MIRANDA FILHO (1979) com a mesma população, observou-se que a população semi-exötica EC teve 4,13\% menos NRP, enquanto que a população semi-exótica EE teve $17,83 \%$ a mais NRP.

Verificou-se, desta forma, que a incorporação de germoplasmas exóticos na população adaptada afetou negati vamente a média da população semi-exótica EC, enquanto que a população semi-exótica EE teve a sua média afetada positivamente. No entanto, as médias das duas populações semi-exóti cas foram. inferiores às médias das raças exóticas originais, conforme os dados retirados de PATERNIANI e GOODMAN (1977), e mostrados na Tabela 8 . 
As significâncias dos quadrados médios (teste F) encontradas para as três populações, indicaram a existência de variação genética entre as famỉlias de meios irmãos avaliadas, podendo-se verificar o potencial destas populações para o melhoramento, atravēs da distribuição das médias, conforme é mostrado na Figura 9.

Os coeficientes de variação experimental obti dos, para cada uma das populações, podem ser considerados co mo baixos na experimentação agricola, uma vez que para as pó pulações semi-exóticas EC e EE estiveram ao redor de 10,5\%, enquanto que para a população adaptada foi $11,02 \%$. Comparan do-se estes coeficientes com a média obtida $(10,76 \%)$ para no ve populações do Departamento de Genética, nota-se a boa pre cisão dos ensaios para o NRP.

Embora não existam referências na literatura para NRP em populações semi-exc̄ticas que sirvam de base para a comparação de tais coeficientes, sabe-se que os caracteres que exibem herdabilidades altas geralmente mostram coeficien tes de variação experimental mais baixos, conforme ocorreu nestes experimentos.

5.2.4. Estimativas de parãmetros genēticos para nūme ro de ramificações do pendão

Observando-se as estimativas das variâncias genéticas aditivas, em (ramificaçöes/planta) ${ }^{2}$, verifica-se que a população semi-exótica EE apresentou o valor mais elevado, ficando a população adaptada com um valor intermediário e a população semi-exötica EC com a estimativa mais baixa. Comparando-se, porém, com a estimativa média de nove populações $\left(21,53 \times 10^{-2}\right)$, obtidas no Departamento de Genética (Tabela 
3), fica evidenciada a superioridade das estimativas das va riâncias genéticas aditivas encontradas no presente estudo, sobressaindo-se a da população EE.

Associando-se as estimativas das variâncias genéticas aditivas das três populações com as médias obtidas para NRP, pode-se averiguar que a população EC além de ter apresentado a menor média para NRP, mostrou também considerá vel quantidade de variabilidade genética para melhorar a ef ciência da planta, seguindo-se das populações E e EE.

Uma vez que já foram relatadas evidências de que uma diminuição do tamanho do pendão conduz a uma maior produção (BUREN et alii, 1974 ; MOCK e SCHUETZ, 1974; GERALDI, 1977), e de que plantas com pendões maiores são prejudiciais na intercepção da 1 uz e na competição por nutrientes (DUNCAN et alii, 1967; HUNTER et ali i, 1969), constata-se a potencialidade da população EC para trabalhos a curto prazo, ficando a população EE para estudos a um prazo mais 1 ongo. Se, por outro lado, for considerado a associação positiva en tre nümero de ramificações do pendão e o índice altura de es piga/altura de planta (PATERNIANI, 1981), consolida-se ainda mais a indicação da população EC para estudos a curto prazo.

As estimativas dos coeficientes de herdabilidade no sentido restrito ao nivel de plantas foram relativamente altas, tendo a população EE mostrado o valor mais elevado, indicando que uma boa porção da variação fenotípica existente é devido a efeitos gênicos aditivos.

Ef etuando-se comparações entre as estimativas obtidas no presente estudo com a estimativa média dos coeficientes de herdabilidade ao nível de plantas $(54,91 \%)$ de no- 
ve trabalhos conduzidos no Departamento de Genética (Tabela 3), verifica-se que somente a população EC mostrou um valor pouco menor $(48,17 \%)$, tendo as populações E e EE apresentados valores mais altos. Ao nível de médias de progênies, as três populações exibiram coeficientes de herdabilidade mais altos que a média das estimativas apresentadas na Tabela 3.

Comparando-se a variabilidade genética das três populações, atravēs dos coeficientes de variação genétí ca e dos indices de variação $\theta$, não foram observadas diferen ças acentuadas das populações semi-exóticas para a população adaptada, percebendo-se, no entanto, que os coeficientes de variação genética obtidos foram superiores à média (9,87\%) de nove estimativas (Tabela 3 ), sendo que os indices de variação $\theta$ ficaram um pouco abaixo da média $(0,94)$.

Utilizando-se do processo de seleção entre e dentro de famílias de meios irmãos (SEDFMI) ou de seleção massal (SM), as estimativas dos progressos genéticos esperados com SM foram maiores do que com SEDFMI, tal como ocorreu nos resultados mostrados por GERALDI (1977), LORDELO (1982) e AGUILAR MORĀN (1984).

De um modo geral, pode-se verificar que os re sultados obtidos mostraram a presença de considerável variabilidade genética para as três populações, destacando-se, es sencialmente, a população EE, dando uma indicação de que pro gressos genéticos serão conseguidos, mesmo com a utilização de métodos simples de melhoramento, como a seleção massal. 


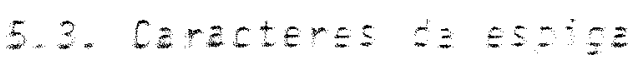

\subsubsection{Avaliaçäo geral para comprimento da espiga}

Comparando-se as mêdias obtidas das três pop lações, em relação a o comprimento da espiga (CE), pode-se verificar que a população semi-exótica EC foi inferior em $11 \%$ à mẻdia da população adaptada, enquanto que a população semi-exótica EE foi superior em 6,00\%. Em relação à média das testemunhas $(16,80 \mathrm{~cm} /$ espiga), foi observada a superioridade em $2,26 \%$ da população EE, sendo as populações E e EC inferio res, respectivamente, em $3,70 \%$ e $14,35 \%$.

Outro aspecto a considerar, $\bar{e}$ o fato de que foi observado uma diferença nas médias do CE de $7,15 \%$ e $41,15 \%$, respectiva mente, para as populações semi-exóticas EC e EE, em relação às médias originais das raças Cravo e Entrelaçado, segundo os dados apresentados por PATERNIANI e GOODMAN (1977), e conforme podem ser vistos na Tabela 8 .

Se forem levadas em consideração a grande fa 1 ta de adaptação da raça Entrelaçado às condições locais (PATERNIANI e GOODMAN, 1977), que tambëm foi comprovada no presente estudo na época do cruzamento, as diferenças existentes de ambiente, manejo e competição entre esta raça original e a população semi-exōtica EE, è de se esperar que ocorram discrepâncias de resultados. No entanto, como é sabido. que ocorre uma compensação entre caracteres relacionados com a produção (MOLL et alii, 1962; TAVARES, 1972), a diminuição nas mẻdias do CE das populações semi-exóticas, em relação à média das raças exóticas, foi compensada em $22,00 \%$ para a po pulação EC e $120,66 \%$ para a população EE, no acréscimo do nü mero de grãos por fileira. 
De um modo geral, pode-se notar que a incorpo ração de genes das raças exóticas na população adaptada foi benéfica no sentido de aumentar a média da população semi-exótica EE, podendo-se ainda observar na Figura 10, os segregantes transgressivos que poderão ser selecionados para se conseguir aumentos mais consistentes no comprimento de es piga; a população semi-exótica EC, apresentou uma clara evidência de um menor comprimento da espiga em relação à popula ção adaptada ESALQ-PBl. Entretanto, convëm ressaltar que o objetivo da introgressão gênica da raça Cravo não foi visando este caráter, mas, principalmente, o número de fileiras de grãos.

As significâncias dos quadrados médios (teste F) encontradas para as três populações mostraram possibilida des de sucesso para aumentar o comprimento de espiga, tendo em vista a deteç̧ão da variação significativa entre as familias de meios irmãos.

A precisão experimental dos ensaios foi boa, uma vez que os coeficientes de variação experimental obtidos para as três populações estiveram abaixo da média encontrada $(8,32 \%)$ para diversas populações (Tabela 4 ).

5.3.2. Estimativas de parāmetros genēticos para comprimento da espiga

A estimativa da variância genētica aditiva da população semi-exötica EC, em (cm/espiga) ${ }^{2}$, foi menor que a da população adaptada, sendo que foi comprovada a superioridade desta estimativa para a população EE. Sabendo-se que a característica marcante da raça Entrelaçado é o acentuado 
comprimento de espiga e que a raça Cravo não possui este atributo (PATERNIANI e GOODMAN, 1977), os resultados aqui ob tidos estão de acôrdo com os esperados, uma vez que a estima tiva da variância genética aditiva da população EE foi 1,37 vezes maior que a da população adaptada, e 1,99 vezes mais alta que a da população semi-exótica EC $\left(96,2156 \times 10^{-2}\right)$.

Apesar dos resultados aqui mostrados terem si do obtidos em um só local, uma boa indicação da variabilidade genética manifestada pelas populações semi-exóticas, prin cipalmente da população EE, pode ser verificada quando são feitas comparações com a média de trinta e seis estimativas reportadas por HALLAUER e MIRANDA FILHO (1981), e com a média de vinte estimativas mostradas na Tabela 4. Se, entretanto, for levado em consideração a interação não significativa encontrada para comprimento de espiga x locais (CORTEZMENDONZA e HALLAUER, 1979), consolida-se ainda mais os resul tados encontrados no presente estudo e os efeitos benéficos decorrentes da incorporação de genes das raças exóticas na população adaptada.

Para as três populações, as estimativas dos coeficientes de herdabilidade no sentido restrito ao nível de plantas foram mais ou menos semelhantes, sendo obtido o maior valor para a população EE $(28,22 \%)$; ao nível de médias de progênies também foi comprovada a superioridade dos coeficientes de herdabilidade para a população EE (44,41\%), tan to em relação às duas populações quanto em relação à média de vinte estimativas $(36,58 \%$ ) em diversas populações (Tabela 4), bem como à média das estimativas $(38,10 \%)$ relatada por HALLAUER e MIRANDA FILHO (1981).

Verificando-se, por outro lado, que as estima 
tivas dos coefientes de herdabilidade ao nivel de plantas pa ra as populações semi-exóticas foram, em média, duas vezes maiores que os encontrados para produção, talvez, a seleção via comprimento de espiga seja mais eficiente para aumentar a produção. No entanto, CORTEZ-MENDonzA e HALlAuER mostraram valores semelhantes para a superioridade dos coefi cientes de herdabilidade e uma boa correlação genética entre estes caracteres, e não recomendaram a seleção para aumento de produção via seleção para comprimento de espiga, uma vez que a seleção direta para produção foi $34 \%$ mais eficiente que através a seleção indireta :

Para cada uma das populações, as estimativas dos progressos genéticos esperados foram mais ou menos semeIhantes, tanto com a SEDFMI quanto com SM, sendo os valores mais elevados obtidos com a população semi-exótica EE, e os valores mais baixos com a população EC. Sabendo que a raça Cravo apresenta espigas curtas (PATERNIANI e GOODMAN, 1977), verificou-se que a introgressão deste germoplasma exótico na população adaptada não exerceu influência no sentido de aumentar a variabilidade genética para comprimento da espiga da população semi-exótica EC. Situação inversa ocorreu para a população EE, constatando-se que ganhos consideráveis pode rão ser obtidos, podendo-se, após quatro a cinco ciclos de seleção massal obter familias com um comprimento médio de espiga próximo ao da rạ̧a exótica Entrelaçado.

A eficiência da seleção massal em uma população adaptada (BSLE), tanto para aumentar quanto para diminuir o comprimento de espiga, foi verificada por CoRTEZ-MENDONZA e HALlauer (1979), que após dez ciclos de seleção conseguiram um aumento médio por geração $0,32 \mathrm{~cm}$, sendo que pa- 
.103.

ra diminuição foi duas vezes maior $(-0,64 \mathrm{~cm})$. Verificaram que as plantas com espigas maiores deram maiores produções que plantas com espigas curtas, porém, a medida que havia um aumento para o comprimento de espiga havia uma redução na profundidade do grão, não ocorrendo mudança na produção. Situação totalmente inversa foi observada para a seleção de es pigas curtas.

Estes resultados foram coerentes com os obtidos no presente estudo, uma vez que a redução do comprimento de espiga das populações semi-exóticas EC e EE, em relação às raças exóticas originais, foi compensada pelo aumento do nümero de grãos por fileira.

Apesar de que o comprimento da espiga não seja mencionado na literatura como um dos componentes da produção LENG, 1954), pode-se constatar que os resultados aqui obtidos estão de acordo com Moll et ali $i$ (1962) e TAVARES (1972), tendo em conta que havendo a diminuição de um componente da produção haverá uma compensação em outro componente, implicando na existência de mudanças correlacionadas da frequência de genes (HALlAUER e MIRANDA FILHO, 1981).

A variabilidade genética das três populações, medida atravēs dos coeficientes de variação genética e dos indices de variação $\theta$, mostrou-se coerente com aquilo que era esperado, uma vez que a população semi-exótica EE apresentou os valores mais altos para ambos os parâmetros, fican do a população a aptada numa amplitude de variação intermediäria, e a população EC apresentando os valores mais baixos. 
5.3.3. Avaliação geral para nümero de grãos por fileira e nümero de fileiras por espiga

As médias obtidas para as populações semi-exó ticas EC e EE foram ligeiramente inferiores à média da popu1 ação adaptada para o número de grãos por fileira (NGF), ocorrendo o inverso para nümero de fileiras por espiga (NFE). Convém destacar que, sendo o principal atributo da raça Cravo o grande nümero de fileiras por espiga (PATERNIANI e GOOD MAN, 1977), esperava-se que ocorresse uma elevação na média da população semi-exótica EC, tal como ocorreu no presente estudo. Pode-se assim, observar que as médias da população adaptada e das testemunhas foram, respectivamente, $18 \%$ e $23 \%$ mais baixas que a média da população EC.

Associando-se, por outro lado, o aumento da média da população EC com a grande quantidade de segregantes transgressivos para NFE, conforme pode ser visto na Figura $12 \mathrm{~A}$, verifica-se que a introgressão da raça Cravo com a popu 1 ação adaptada gerou um acréscimo na variabilidade da popula ção semi-exótica, com amplas perspectivas parafuturos ganhos com a seleção.

Apesar de a população semi-exótica EE ter mostrado um leve aumento (6\%) no NFE em relação à população adaptada, pode-se verificar que a incorporação de genes da raça Entrelaçado tambëm foi benéfica para ampliar a variabi1 idade desta população semi-exótica, uma vez que a amplitude de variação mostrada (Figura 12B) foi quase duas vezes mais que a da população adaptada.

Com relação à característica NGF, é necessärio mencionar que apesar das médias apresentadas pelas popu1 ações semi-exóticas EC e EE terem sido um pouco mais baixas 
$(2,80 \%$ e $5,80 \%)$ que a média da população adaptada, verificou-se que na distribuição das médias (Figura 11) a população EC apresentou uma amplitude de variação com valores mais altos que a população adaptada. Para a população EE, consta tou-se uma amplitude de variação das médias quase duas vezes menos que a da população adaptada, com o grande mérito de que a média da população semi-exótica foi $120,66 \%$ mais alta que a média da raça exótica original, conforme consta na Tabela 8 ).

Considerando que o caràter marcante da raça Cravo é o grande nümero de fileiras por espiga e que um dos objetivos do presente trabalho foi a incorporação de genes desta raça na população adaptada, pode-se verificar que a população adaptada teve $18 \%$ menos NFE que a população semi -exötica EC, sendo que esta população teve 2,80\% menos NGF que a população adaptada.

Por outro lado, foi observado que a média da população Ec te ve $15 \%$ menos NFE que a raça exötica Cravo, sendo que esta dí minuição foi compensada no NGF, uma vez que a média original desta raça foi $22 \%$ menor que a média da população EC. Verifica-se, desta forma, que houve uma compensação entre estes componentes de produção, tal como relataram Moll et alii, (1962) e TAVARES (1972).

Para as três populações e para ambos os caracteres, as significâncias dos quadrados médios (teste F) encontradas mostraram a existência de variação entre famí1 ias de meios irmãos, indicando uma maior variação para a po pulação semi-exótica EC.

A precisão experimental dos ensaios, tanto pa ra NGF quanto para NFE, pode ser considerada boa, tendo em vista que os coeficientes de variação experimental obtidos, 
para cada uma das populações e para ambas as caracteristicas, situaram-se abaixo da média do levantamento efetuado (Tabe1a 5) para NGF $(13,15 \%)$ e para NFE (6,5\%).

\subsubsection{Estimativas de parāmetros genéticos para nūme ro de grãos por fileira e nūmero de fileiras por espiga}

Comparando-se as estimativas das variâncias genéticas aditivas das três populações, em (número fileirasl espiga) ${ }^{2}$, verifica-se que as populações semi-exóticas EC e EE apresentaram maiores estimativas para NFE que a população adaptada, principalmente a população EC $\left(220,8668 \times 10^{-2}\right)$, que foi 1,96 vezes superior. Lembrando que a raça Cravo é caracteri zada por um grande número de fileiras por espiga (PATERNIANI e GOODMAN, 1977), era esperado que a incorporação de genes desta raça na população adaptada aumentasse a variabilidade genética, tal como ocorreu no presente estudo.

Esta maior variabilidade genética da população EC também foi comprovada em relação aos Compostos A e B (QUEIROZ, 1969) e à variedade Centralmex (MOTA, 1974), uma vez que as estimativas das variâncias genéticas aditivas apresentadas pelos autores acima mencionados foram inferiores à estimativa obtida para esta populaçäo semi-exótica.

Para as estimativas das variâncias genéticas aditivas dos caracteres nümero de grãos por fileira, expressas em (nümero grãos/fileira) ${ }^{2}$, a população EC apresentou um valor mais a1to $\left(1.074,1468 \times 10^{-2}\right)$ que a população adaptada, ao passo que a população EE mostrou um valor mais baixo $(617,5068 \mathrm{x}$ $10^{-2}$ ). Comparando-se estes resultados com os obtidos 
por QUEIROZ (1969) e MOTA (1974), constatou-se a superiorida de tanto das populações semi-exóticas quanto da população adaptada, desde que as estimativas aqui relatadas foram mais altas. Mesmo que as estimativas que serviram de base para as comparações não sejam referentes à populações semi-exóticas, elas forneceram uma boa indicação da potencialidade genética das populações semi-exóticas aqui relatadas, tendo em vista que os Compostos e a variedade exibiram quantidades considerāveis de variância genética aditiva.

Embora os resultados encontrados na literatura americana (Tabela 5), para estimativas de variâncias gene ticas aditivas, sejam obtidos de anälises efetuadas em maís de um local ou ano, pode-se notar que, principalmente para a população semi-exótica EC, as estimativas do presente estudo foram maiores, tanto para NFE quanto para NGF.

Os valores relativamente altos encontrados pa ra as estimativas dos coeficientes de herdabilidade no senti do restrito ao nivel de plantas, mostraram que para NFE, métodos simples de seleção proporcionarão progressos substanciais, principalmente para a população EC; para NGF, estes coeficientes foram mais baixos e mais ou menos semelhantes entre si nas três populações, sendo o maior valor apresentado pela população EC.

Levando em conta que as estimativas dos coef cientes de herdabilidade relatadas na literatura foram ao ni vel de médias de parcelas, comparações precisas não podem ser feitas; no entanto, as estimativas aqui obtidas, para os coeficientes de herdabilidade ao nível de mëdias de progênies, estiveram situadas na amplitude de variação de $50 \%$ a $70 \%$, conforme a distribuição de faixas apresentada por HALLAUER e MIRANDA FILHO (1981) para NFE, e maiores que a média 
apresentada na Tabela 5. Para NGF, as estimativas aqui obti das mostraram valores próximos à média de dezoito estimativas (HALLAUER e MIRANDA FILHO, 1981), acreditando-se que estejam dentro da faixa de variação.

Para ambos os caracteres e para as três populações, as estimativas dos progressos genéticos esperados foram maiores com a seleção massal do que com SEDFMI, comprovando os valores relativamente altos encontrados para os coeficientes de herdabilidade, e indicando que quantidades consideráveis da variação fenotípica total para NFE e NGF são devido às variâncias genéticas aditivas.

Outro aspecto a considerar, è o fato de que a média do NGF da população EC será semelhante à média da popu 1 ação adaptada com apenas um a dois ciclos de seleção massal, sendo que para a populaçäo EE serão necessärios mais que dois ciclos. Pode-se constatar, por outro lado, que a média do NFE da população EC será equivalente à mëdia da raça Cravo com três ciclos de seleção massal, haja visto o pro gresso que é esperado ( 1,87 fileiras/espiga), bem como à grande quantidade de segregantes transgressivos (Figura 12A).

A maior variabilidade genética da população EC também foi comprovada, tanto para NFE quanto para NGF, uma vez que os coeficientes de variação genética foram mais altos que os obtidos com a população adaptada, sendo no entanto, os indices de variação $\theta$ mais ou menos semelhantes. Com relação à população semi-exótica EE, tanto os valores ob tidos para os coeficientes de variação genética quanto para os Indices de variação $\theta$ foram um pouco menores que os da po pulação adaptada, estando, porém, coerentes com a maioria das estimativas dos parâmetros genéticos e de conformidade com o esperado, em decorrência dos caracteres inerentes 
da raça Entrelaçado.

\subsubsection{Avaliação geral para diāmetro da espigas e do sabugo}

Baseando-se na média do diâmetro de espiga (DE) da população adaptada, foi verificado que a média da po pulação semi-exótica EC foi um pouco superior, ocorrendo o inverso para a população semi-exótica EE. Em relação à média das testemunhas, a única população que apresentou menor DE foi a população EE, sendo mantida esta mesma ordem para diâmetro de sabugo (DS).

Efetuando-se a diferença entre DE e DS, verificou-se que o comprimento do grão das populações E, EC e EE foi respectivamente, 1,$33 ; 1,56$ e $1,24 \mathrm{~cm}$. Comparando-se com a mẻdia do comprimento de grãos das testemunhas $(1,33$ $(\mathrm{m})$, percebe-se que a população semi-exótica EC exibiu grãos com maior comprimento, sendo este aumento acompanhado por uma redução no número de grãos por fileira. Assim sendo, no ta-se, mais uma vez, a compensação existente entre o aumento de um caräter associado com a produção e a diminuição em um dos componentes da produção (MOLL et alii, 1962; TAVARES, 1972 ).

De um modo geral, as diferenças encontradas nas médias de DE e DS das populações EC e EE, em relação às médias da população adaptada, mostraram que a introgressão de genes exóticos foi capaz de alterar as médias destes caracteres, podendo-se perceber com maior clareza nas Figuras 13 e 14.

As significâncias dos quadrados médios (teste 
F) detectadas em ambos os caracteres e para as três populações, mostraram as variações entre famỉlias de meios irmãos, indicando a possibilidade de sucesso em escolher familias, dentro de cada população, de acordo com o objetivo do progra ma de melhoramento.

Os coeficientes de variação experimental obti dos, situaram-se ou abaixo da média ou foram muito semelhantes à média do levantamento mostrado na Tabela 6, evidencian do a boa precisão experimental dos ensaios.

5.3.6. Estimativas de parāmetros genēticos para diāmetro da espiga e do sabugo

Os valores encontrados para as estimativas das variâncias genéticas aditivas das populações EC e EE, mostraram os efeitos consistentes das presenças dos germoplasmas exóticos na população adaptada, desde que estes valores foram mais do que uma e duas vezes superiores, respectivamente, para DE e DS, que a estimativa obtida para a população adaptada.

Para se ter uma idéia geral da variabilidade genética existente nas populações estudadas, uma vez que as comparações não são precisas, as estimativas obtidas para as variâncias genéticas aditivas foram maiores que a média de vinte e uma estimativas (Tabela 6), bem como à média de trin ta e cinco estimativas (HALLAUER e MIRANDO FILHO, 1981), tan to para DE quanto para DS, destacando-se, essencialmente, as populações semi-exöticas.

Para DE, as magnitudes relativas dos coeficieentes de herdabilidade ao nível de médias de progênies fo 
ram similares para as populações E e EE, sendo um poucomais baixa para a população EC (42,27\%); para DS, o valor mais baixo foi encontrado para a população adaptada, ficando a po pulação EC com o valor mais alto $(66,90 \%)$. Apesar da 1 itera tura americana relatar estes coeficientes de herdabilidade a o nível de médias de parcelas, torna-se difícil a realização de comparações precisas; mesmo assim, pode-se constatar que as populações semi-exöticas apresentaram valores mais a tos que a média fornecida por HALlauer e MIRANDA FilHo (1981), bem como à média mostrada na Tabela 6.

Considerando que as estimativas dos progressos genëticos esperados foram baseados somente na SEDFMI, pode-se observar que os ganhos com DS foram de duas a três vezes maiores que para DE, destacando-se a população EE, para ambos os caracteres.

Com relação ao coeficiente de variação genétí ca, as populações semi-exöticas apresentaram vạlores mais elevados que a população adaptada para os dois caracte res, sobressaindo-se a população EE. No que se refere ao Indice de variação $\theta$, a população semi-exóitca EE destacou-se das demais para DS, sendo a população EC um pouco superior à população adaptada. No entanto, para DE, as populações E e EE mostraram indices de variação - muito semelhantes, enquanto que a população EC exibiu o valor mais baixo.

Analisando-se conjuntamente os resultados obtidos para estes dois caracteres, averiguou-se uma maior variabilidade genética na população EE do que na população EC. Se for levado em consideração o fato de que alguma sele ção tenha sido praticada na raça Cravo e nenhuma na raça Entrelaçado, era esperado que a incorporação de genes da raça 
Cravo na população adaptada não exibisse tanta variabilidade genética, sendo o inverso esperado para a população semi-exó tica EE, tal como ocorreu no presente estudo.

\subsection{Considerações finais}

- sucesso de um programa de melhoramento depende da variabilidade genética presente na população. Recentemente, além dos melhoristas de plantas estarem interessados em encontrar caminhos para aumentar esta variabilidade, também estão conscientes com a preservação de germoplasma que não estä sendo usado atualmente, mas, que serä de valor no futuro. Isto tem resultado em um crescente interesse em germoplasma exötico e sua preservação. O interesse em germo plasma exótico tem sido feito em duas direções: para caracte res qualitativos e quantitativos.

Assim sendo, entre os germoplasmas exóticos existentes no Brasil, as raças de milho Cravo e Entrelaçado mereceram a atenção do presente estudo, tendo em vista que apresentam caracteres peculiares, quais sejam respectivamente, grande número de fileiras e acentuado comprimento de espiga. Cada uma destas raças foi cruzada com a população adaptada ESALQ-PB1, e as populações resultantes foram de nominadas semi-exóticas EC e EE, uma vez que contêm $50 \%$ de genes de raças exóticas e 50\% de genes da população adaptada.

Convēm ressaltar que os principais objetivos do presente estudo foram: i. verificar as mudanças ocorridas nas médias das duas populações semi-exóticas em relação à mé dia da população adaptada; ii. determinar a potencialidade 
genética das raças para fins de melhoramento, comparando-se as estimativas dos parâmetros genéticos das populações semi-exóticas com as estimativas da população adaptada, a fim de se verificar o efeito da incorporação de genes na variabilidade genética.

Para o caräter produção (peso de espigas e de grãos), as médias das populações semi-exóticas EC e EE foram afetadas negativamente com a introgressão de genes exóticos, enquanto que para a variabilidade genética foram verificados efeitos positivos.

Para os caracteres da planta (altura da planta, altura da espiga e nümero de ramificaçóes do pendão), as médias da população Ec foram influenciadas positivamente pe1 a incorporação de genes da raça Cravo, sendo que para a população EE os efeitos foram negativos com a introdução de ge nes da raça Entrelaçado.

No que diz respeito à variabilidade genética, a presença de genes exöticos da raça Entrelaçado na população adaptada mos trou um efeito benéfico na população EE, uma vez que todas as estimativas dos parâmetros genéticos foram maiores que as obtidas com a população adaptada, acontecendo, de um modo geral, o inverso para a população EC.

A presença do germoplasma exótico Entrelaçado mostrou efeitos consistentes para comprimento de espiga, tan to na elevação da média quanto no aumento da variabilidade genética da população EE; resultados idênticos foram obtidos com a incorporação de genes da raça Cravo, para os carac teres nümero de fileiras por espiga. Isto era esperado, uma vez que estes são os caracteres marcantes de cada uma das raças exōticas. 
Para os demais caracteres de espiga ( $n \bar{u}-$ mero de grãos por fileira, diâmetro da espiga e do sabugo), pode-se constatar, de um modo geral, que tanto as médias quanto as estimativas relacionadas à variabilidade genética da população EC foram afetadas positivamente com a introgres são de genes da raça Cravo. Por outro lado, a incorporação de genes da raça Entrelaçado influenciou negativamente na mé dia destes três caracteres, exibindo, porém, um efeito benéfico para aumentar a variabilidade genética, exceto para número de grãos por fileira.

Analisando conjuntamente os resultados, perce be-se o benefício resultante da incorporação de genes das ra ças exóticas Cravo e Entrelaçado na população adaptada, haja vista a considerável quantidade de variabilidade genética que pode ser explorada nas populações semi-exóticas EC e EE. Acredita-se que com programas de melhoramento intrapopulacio nais, além de se conseguir elevar a média de cada uma das po pulações semi-exóticas, haverā um aumento gradativo e contínuo na frequência dos alelos favoráveis, obtendo-se, então, duas sub-populações com maior diversificação no conjunto gênico.

No futuro, uma outra excelente alternativa pa ra o aproveitamento destas duas populações semi-exóticas seria na obtenção de linhagens, que certamente resultariam em hỉbridos bem promissores, haja visto a divergência genética existente nas sub-populações.

Finalmente, há que se considerar também que a manutenção e melhoramento das populações semi-exóticas contribuirão para a preservação de genes, desde que seja mantido um tamanho efetivo populacional a nivel suficiente para minimizar a probabilidade de perdas de alelos. 


\section{Conclusões}

Nas condições do presente trabalho, as interpretações dos resultados obtidos permitem relacionar as seguintes conclusões:

a. As populações semi-exóticas Cravo x ESALQ-PB1 (EC) e Entrelaçado $x$ ESALQ-PB 1 (EE) apresentaram médias mais baixas para peso de espigas e peso de grãos que as da populaça adaptada ESALQ-PB1 (E), mostrando que a incorporação de 50\% de genes das raças exóticas Cravo e Entrelaçado no material adaptado influenciou negativamente nas médias das populações semi-exóticas.

b. As magnitudes relativas dos parâmetros genéticos estimados para peso de espigas e peso de grãos das populações semi-exóticas EC e EE foram maiores que as da população adaptada, indicando a potencialidade genética das duas ra ças para aproveitamento em programas de melhoramento.

c. Sugere-se, antes de efetuar a introgressão de germoplasma exótico numa população adaptada, que sejam realizados al- 
guns ciclos de seleção massal acompanhados de suave seleção para os caracteres agronômicos desejāveis, principalmente, quando a procedência de germoplasma for de região bem diferente.

d. Os benefícios resultantes da introgressão de genes da raça Cravo foram confirmados na população semi-exótica EC, uma vez que tanto para altura da planta quanto para altura da espiga suas médias foram mais baixas que a da população adaptada. Para a população semi-exótica EE, estas médias foram um pouco mais altas que as da população adap tada, mas, em relação à raça original Entrelaçado, houve aproximadamente uma redução de $15,8 \%$ em ambos os caracteres.

e. Verificou-se a presença de suficiente variabilidade genética para altura da planta e da espiga nas duas populações semi-exóticas, uma vez que valores relativamente altos foram encontrados para os coeficientes de herdabilida de, progressos genéticos etc.. podendo-se conseguir ganhos substanciais com esquemas simples de seleção.

f. A presença de gerıes da raça Cravo na população adaptada teve um efeito benéfico em reduzir a média do número de ramificações do pendão da população semi-exótica EC, sendo que na população semi-exótica EE, a incorporação de ge nes da raça Entrelaçado aumentou a média deste caráter. Os valores relativamente altos encontrados para as estimativas dos parâmetros genéticos nas três populações, destacando-se, principalmente, a população EE, mostraram que ganhos genéticos poderão ser obtidos, com esquemas simples de seleção.

g. Apesar de que a média para o comprimento da espiga da popula 
ção semi-exótica EE tenha sido mais alta que a da população adaptada, o efeito positivo da incorporaça de genes da raça Entrelaçado não foi tão acentuado como era esperado, uma vez que este é o caráter marcante desta raça exótí ca. Para a população semi-exótica EC, a incorporação de genes teve um pequeno efeito negativo na média do comprimento da espiga, tendo em vista que a média da população adaptada foi um pouco maior.

h. Em relação à população adaptada, verificou-se que, para comprimento da espiga, a população semi-exótica EE apresen tou uma maior variabilidade e potencialidade genética que a população semi-exótica EC, podendo-se, inclusive, após quatro a cinco ciclos de seleção serem obtidas familias com um comprimento médio da espiga próximo ao da raça Entrelaçado.

i. Com referēncia ao caráter nümero de fileiras por espiga, os beneficios resultantes da incorporaça de $50 \%$ de genes exóticos na população adaptada foram bem mais acentuados

* com a raça Cravo do que a Entrelaçado, haja visto que tanto a média quanto as estimativas dos parāmetros genéticos da população semi-exótica EC foram mais elevadas que os va lores obtidos com a população adaptada. Apesar de as médias obtidas com nümero de grãos por fileira para as populações semi-exóticas terem sido ligeiramente inferiores à média da população adaptada, os parāmetros genéticos estimados mostraram haver variabilidade genética suficiente pa ra permitir progressos com seleção, destacando-se, principalmente, a população EC.

j. Não obstantè as médias de diāmetro da espiga e diāmetro do sabugo terem sido mais ou menos semelhantes para as très po 
pulações, pode-se averiguar, através da amplitude de variação, que um grande número de famílias da população semi-exōtica EC mostrou uma distribuição de médias com valo res mais altos que a população adaptada, ocorrendo o inverso para a população EE. Em termos de variabilidade ge nética, as populações semi-exóticas exibiram maior potencialidade que a população adaptada, sobressaindo-se a população EE.

1. Considerando a estrutura genética de cada uma das raças exóticas e tendo por base os resultados obtidos, recomenda-se o aproveitamento da potencialidade genética apresen tada pela população semi-exótica EC para programas de me1 horamento a curto prazo, enquanto que a população EE poderá ser aproveitada para programas a longo prazo.

m. Seria interessante que, ao invés de se trabalhar com popu 1 ações que tivessem $50 \%$ de genes de germoplasma adaptado e $50 \%$ de genes de germoplasma exótico, fossem feitos concomitantemente programas que incorporassem tambëm $25 \%$ de genes de germoplasmas exóticos. Com este procedimento, supõe-se que haveria uma elevação na média dos principais caracteres agronômicos das populações semi-exóticas sem haver grandes reduções nas suas variabilidades genétićas. 


\section{Literatura Citada}

ACOSTA, A.E. e P.L. CRANE, 1972. Further selection for

lower ear height in maize. Crop. Sci., 12: 165-167.

AGUILAR MORAN, J.F., 1984. Avaliação do potencial de linhagens e respectivos testadores obtidos de duas populações de milho (Za mays L.).- Piracicaba. ESALQ/USP, 118 p. (Dissertação de Mestrado).

ALLARD, R.W., 1970. Population structure and sampling methods. In: FRANKEL, 0.H. e E. BENNET, Eds. Genetic Resources in Plants. Osford, Blackwell scientific Publications, p. 97-108.

ANDRADE, J.A.C. e J.B. MIRANDA Fo, 1979. Estimativas de parâmetros para os caracteres de pendão na população ESALQ$\mathrm{PB} 1$ de milho. Relatório Cientifico do Departamento de Ge nética, ESALQ/USP. Piracicaba, 13: 15-21.

BARRIGA BEZANILLA, G.P., 1971. A eficiência de alguns culti vares de milho (Zea maiss L。) na produção de grãos. Piracicaba, ESALQ/USP, 84 p. (Dissertação de Mestrado). 
BARTUAL, A.R. e A.R. HALLAUER, 1976. Variability among unselected maize inbreed 1 ines developed by full-sibbing. Maydica, 21: 49-60.

BENNET, E., 1970. Adaptation in wild and cultivated plants populations. In: 0.H. FRANKEL e E. BENNET, Eds. Genetic Resources in Plants. Oxford, Blackwell Scientific Publications, p.115-130.

BLISS, F.A., 1981. Utilization of vegetable germplasma. Hortscience, 16: 129-132.

BRANDOLINI, A.G., 1969. European races of maize. Proc. of the $24^{\text {th }}$ Hybrid Corn Ind. Res. Conf., 24: 36-48.

BRIEGER, F.G., J.T.A. GURGEL, E. PATERNIANI, A. BLUMENSCHEIN e M.R. ALLEONI, 1958. Races of maize in Brazil and other eastern South American Countries. Washington, Nationa 1 Academy of Sciences-National Research Council. Publication no 593 .

BRIEGER，F.G.，1963. Collection and evaluation of indigenous races of maize. Gen. Agraria, 63: 259-264.

BROWN, W.L., 1953. Sources of germplasm for hybrid corn. Proc. of the $8^{t h}$ Annu. Hybrid Corn Ind. Res. Conf., 8: $11-16$.

BROWN, W.L., 1960. Races of maize in the West Indies. Washington, National Academy of Sciences-National Research Council: Publication no 792 .

BROWN, W.L., 1975. A broader germplasm base in corn and sorghum. Proc. of the $30^{\text {th }}$ Hybrid Corn Ind. Res. Conf., 30: $81-89$. 
.121 .

BROWN, W.L. e M.M. GOODMAN, 1977. Races of maize. In: G.F. SPRAGUE, Ed. Corn and Corn Improvment. American Soc. Agron., Madison, p. 97-108.

BUREN, L.L., J.J. MOCK e I.C. ANDERSON, 1974. Morphological and physiological traits in maize associated with tolerance to high plant density. Crop. Sci., 14: 426-429.

CHI, R.H., S.A. EBERHART e L.H. PENNY, 1969. Covariances among relatives in a maize variety. Genetics, 63: 511-520.

COCHRAN, W.G. e G.M. COX, 1957. Experimental designs. 2. ed. New York, John Wiley and Sons, 611 p.

COMPTON, W.A., C.O. GARDNER e J.H. LONNQUIST, 1965. Genetic variability in two open-po!. linated varieties of corn (Zea mays L.) and their $F_{1}$ progenies. Crop Sci., 5: 505-508.

COMPTON, W.A. e K. BAHADUR, 1977. Ten cycles of progress from modified ear to row selection in cor (Zea mays, L.). Crop Sci., 17: 378-380.

COMPTON, W.A., R.F. MUMM e B. MATHEMA, 1979. Progress from adaptative mass selection in incompletely adapted maize population. Crop Sci., 19: 531-533.

COMSTOCK, R.E. e H.E. ROBINSON, 1948. The components of genetic variance in populations. Biometrics, 44: 254-266.

COMSTOCK, R.E. e H.F. ROBINSON, 1952. Estimation of average dominance of genes. In: J.W. GOWEN, Ed. Heterosis. Ames, Iowa State College Press, p. 494-516. 
CORTEZ-MENDONZA, H. e A.R. HALlAUER, 1979. Divergent mass selection for ear lenght in maize. Crop Sci., 19: 175178 .

CRISŌSTOMO, J.R., 1978. Estimação de parâmetros genéticos em duas populações de milho (Zea mays L.). Piracicaba, ESALQ/USP, 71 p. (Dissertação de Mestrado).

CUNHA, M.A.P., 1976. Seleção entre e dentro de famílias de meios irmãos no milho (Zea mays L.) ESALQ-HV-1. Piracica ba, ESALQ/USP, 84 p. (Tese de Doutorado).

DARRAH, L.L.; S.A. EBERHART e L.H. PENNY, 1972. A maize breeding methods study in Kenya. Crop Sci., 12: 605-608.

DUDLEY, J.W., 1973. Seventy generation of selection for oil and protein in the corn kernel. Proc. of the $28^{\text {th }}$ hybrid Corn Ind. Res. Conf., 28: 123-136.

DUNCAN, W.G., W.A. WILLIAMS e R.S. LOOMIS, 1967. Tassels and the productivity of maize. Crop Sci., 7 : 37-39.

DUVICK, D.N., 1981. Genetic diversity in major crops on the farm and in reserve. In: Thirteenth International Botanical Congress, Sydney, Austrá1ia, p. 1-28.

EBERHART, S.A., R.H. MOLL, H.F. ROBINSON e C.C. COCKERHAM, 1966. Epistatic and other genetic variances in two varieties of maize. Crop Sci., 6 275-280.

EBERHART, 'S.A., 1971. Regional maize diallels with U.S. and semiexotic varieties. Crop Sci., 11: 911-914. 
EFRON, Y. e H.L. EVERETT, 1969. Evaluation of exotic germplasm for improving corn hybrids in northern United states. Crop Sci., 9 : 44-47.

EL-ROUBY, M.M。 e L.H. PENNY, 1967. Variation and covariation in a high oil population of corn and their implications in selection. Crop Sci., 7: 216-219.

EL-ROUBY, M.M。, Y.S. KORAIEM e A.A. NAWAR, 1973. Estimation of genetic variance and its components in maize under stress and nonstress enviroments. I. Planting data. Egypt. J.Genet. Cytor., 2: 10-19.

FISHER, R.A., 1918. The correlations between relatives on the supposition of Mendelian inheritance. Trans. Roy. Soc., 52: 399-433.

GALAL, H.E., S.A.ABD-ALLA e Y.A. EL-KASSABY, 1977. Effect of sample size on precision of the estimates of senctic variance in maize. I. Yield. Egypt. J. Genet. Cytor., 6: 293-305.

GALAL, H.E., S.A. ABD-ALLA e Y.A. KASSABY, 1977. Effect of sample size on precision of the estimates of genetic variance in maize. II. Ear caracters. Egypt. J. Genet. Cytol., 6: 306-318.

GALLINAT, W.C., 1977. The origin of corn. In: G.F. SPRAGUE, Ed. Corn and Corn Improvment. Amer. Soc. Agron., Madison, p 1-47. 
GARDNER, C.O., P.H. HARVEY, R.E. COMSTOK e H.F. ROBINSON, 1953. Dominance of genes controlling quantitative characters in maize. Agron. J., 45: 186-191.

GARDNER, C.O. e J.H. LONNQUIST, 1959. Linkage and the degree of dominance of genes controlling quantitative characters in maize. Agron. J., 51:524-528.

GARDNER, C.0., 1961. An evaluation of effects of mass selection and seed irradiation with thermal neutrons on yield of corn. Crop Sci., 1: 241-245.

GENTER, C.F., 1976. Mass selection in a composite of intercrosses of Mexican races of maize. Crop Sei., 16: 556-558.

GERALDI, I.0., 1977. Estimação de parâmetros genéticos para caracteres de pendão de milho (Zea mays L.) e perspectivas de melhoramento. Piracicaba, ESALQ/USP, 103 p. (Dis sertação de Mestrado).

GERRISH, E.E., 1983. Indications from a diallel study for interracial maize hydridization in the corn belt. Crop sci., 23: 1082-1084.

GHINI, R. e J.B. MIRANDA FO, 1979. Herdabilidade da altura de planta e da espiga no segundo ciclo de seleção da popu lação ESALQ-PBI de milho. Relatório Cientifico do Departamento de Genética, ESALQ/USP. Piracicaba, 13: 130-138.

GOODMAN; $\dot{\mathrm{M}} . \mathrm{M} ., 1965$. Estimates of genetic variance in adapted and exotic population of maize. Crop Sci., 5 : 87-90. 
GRAFIUS, J.E., 1960. Does overdominance exist for yield in corn? Agron.J., 52: 361 .

GRIFFING, B. e E.W. LINDSTROM, 1954. A study of the combining abilities of corn inbreeds having varying proportions of Corn Belt and non Corn Belt germplasm. Agron. J., 46: 545-552.

GRANT, U.J., W.H. HATHAWAY, D.H. TIMOTHY, C.D. CASSALETT e L.M. ROBERTS, 1963. Races of maize in Venezuela, Washington, National Academy of Sciences-National Research Council. Publication no 1136.

GROBMAN, A., W. SAlHAUANA, R. SEVILlA e P.C.C. MANGELSDORF, 1961. Races of maize in Peru. Washington, National Academy of Science - National Research Council Publication no 915 .

HALLAUER, A.R. e J.A. WRIGHT, 1967. Genetic variances in the open pollinated variety of maize. Der Zuchter, 37 : $178-185$.

HALLAUER, A.R., 1971. Change in genetic variance for seven plant and ear traits after four cycles of reciprocal recurrent selection for yield in maize. Iowa State Journal of Science, 45: 575-593.

HALLAUER, A.R. e J.H. SEARS, 1972. Integrating exotic germoplasm into corn belt breeding programs. Crop Sci., 2: $203-206$.

HALLAUER, A.R. e D。 MALITHANO, 1976. Evaluation of maize varieties for their potential as breeding populations. Eyphytica, 25: 117-127. 
HALLAUER, A.R., 1977 . Experimental estimates of genetic parameters in cross-fertilized annuals. Agron. Abst., p. 57 .

HALLAUER, A.R., 1978. Potential of exotic germplasm for maize improvment. In: International Maize Symposium, W.L. Wa1den, Ed. New York, p. 229-249.

HALLAUER, A.R. e J.B. MIRANDA FO, 1981. Quantitative Genetics in Maize Breeding.' Ames, Iowa State University Press. 468 p.

HANSON, W.D., 1959. Theoretical distribution of the initial linkage block lenghts intact in the gametes of a population intermated for $n$ generations. Genetics. 44: $839-846$.

HANSON, W.D. e E.C. JOHNSON, 1981. Evaluation of an exotic maize population adapted to a locality. Theor. Appl. Genet., 60: 55-63.

HARLAN, J.R., 1961. Agricultural origins: centers and noncenters. Science, 174: 468-474.

HATHAWAY, W.H., 1957. Races of maize in Cuba. Washington, National Academy of Sciences-National Research Council. Publication no 453 .

HULL, F.H., 1945. Recurrent selection and specific combining ability in corn. J.Am. Soc. Agron., 37: 134145 . 
.127.

HUNTER, R.B., T.B. DAYNARD, D.J. HUME, J.H. TANNER, J.D. CUR TIS e L。W. KENNENBERG, 1969. Effects of tassel removal on grain yield of corn (Zea mays L.). Crop Sci., 4: 405-406.

HUNTER, R.B., G.G. MORTIMORE e L.W. KENNERBERG, 1973. Inbred maize performance following tassel and leaf removal. Agron. J., 65: 471-472.

JENSEN, N.F., 1962. A wor 1 d germ plasm bank for cereal. Crop sei., 2: 361-363.

JONES, D.F., 1918. The effects of inbreeding and crossbreeding upon development. Connecticut Agric. Exp. Sta. BuZZ., 207: 5-100.

KIESSELBACH, T.A., 1922. Corn investigations。 Nebraska Agric: Expt. Sta. Res. Buzz., n! 20.

KRAMER, H.H. e A.J . ULLSTRUP, 1959。 Preliminary evaluations of exotic maize germplasm. Agron. J., 51: 687-689.

KULESHOV, N.N., 1928. Some peculiarities in the maize of Asia. Bulz. Appl. Bot. and Plant Breed., 19: 325-374.

KULESHOV, N.N., 1933. World's diversity of phenotypes of maize. J. of the Amer. Soc. Agron., 25: 688-700.

LAWRENCE, P.K. e K.J. FREY, 1975. Backcross variability for grain yield in oat species crosses. Euphytica, 24: 77-85.

LENG, E.R., 1953. Expression of heterosis and apparent degree of dominance in the major components of grain yield in maize. Genetics, 38: 674-675. 
LEONARD, W.A. e T.A. KIESSELBACH, 1932. The effect of the removal of tassels on the yield of corn. Agron. J., 24: 514-516.

LIMA, M., 1977. Seleção entre e dentro da famílias de meios irmãos na população de milho ESALQ-VD-2. Piraciaaba, ESALQ/USP, 71 p. (Dissertação de Mestrado).

LIMA, M。 e E. PATERNIANI, 1977. Estimativas de parâmetros genéticos e fenotípicos em progênies de meios irmãos de milho (Zea mays L。) e suas iuplicaçöes no melhoramento. Relatório Cientifico do Departamento de Genética, ESATQ/ USP. Piracicaba, 11: 84-89.

LIMA, M., N. GIMENES-FERNANDEE, J.B. MIRANDA FILHO e J.C.V. A. PEREIRA, 1982. Introduction of maize (Zea mays L.) germplasms as sources for downy mildew (Peronosclerospora sorghi) resistance. Maydica, 27: 159-168.

LINDSEY, M.F., J.H. LONNQUIST e C.O. GARDNER, 1962. Estimates of genetic variance in open-pollinated varieties of cornbelt corn. Crop Sei., 2 : 105-108.

LONNQUIST, J.H., 1961。 Progress from recurrent selection procedures for the improvement of cornpopulations. Nebraska Agric. Expt. Sta. Res. Buzz., 197. 33 .

LONNQUIST, J.H., 1964. A modification of the ear-to-row procedure for the improvement of maize population. Crop sci., 4: 227-228.

LONNQUIST, J.H., 1967. Mass selection for prolificacy in maize. Der Zuchter, 37: 185-188. 
LONNQUIST, J.H., 1974. Consideration and experiences with recombinations of exotic and corn belt maize germplasms. Proc. of the $29^{\text {th }}$ Hybrid Corn Ind. Res. Conf., 29: 102117.

LORDEI.O, J.A.C., 1082. Parâmetros genéticos das populações de milho Piranão VD-2 e Piranão VF-1. Piracicaba, ESALQ/ USP, 63 p. (Dissertação de Mestrãdo).

MALMM, N.R., 1968. Exotic germplasm use in sorghum improvment. Crop Sci., 스: 295-298.

MARANI, A., 1967. Heterosis and combining ability in intraespecific and interspecif crosses of cotton. Crop sci., 7 : 519-522.

MARQUEZ-SANCHEZ, F。 e A.R. HALLAUER, 1970. Influence of sample size on the estimation of genetic variances in a synthetic variety of maize. I. Grain yield. Crop Sci., 10: $357-361$.

MARQUEZ-SANCHEZ, F. e A.R. HALLAUER, 1970. Influence of sample size on the estimation of genetic variance in a synthetic variety of maize. II. Plant ear characters. Iowa state Journal of Science, 44: 423-436.

MILLER, J。, 1973. Genetic erosion: crop plants threatened by government neglect. Science, 182: 1231-1233.

MIRANDA Fo, J.B., 1974. Cruzamentos dialélicos e síntese de compostios de milho (Zea mays L.) com ênfase na produtividade e no porte da planta. Piracicaba, ESALQ/USP, 116 p. (Tese de Doutorado). 
MIRANDA Fo, J.B., 1977. Avaliação de famỉlias de meios irmãos na população ESALQ-PB1. Relatório Científico do Departamento de Genética, ESALQ/USP. Piracicaba, 11: 90-94.

MIRANDA Fo, J.B., 1978. Herdabilidade da altura de planta e da espiga na população ESALQ-PB1. Relatório Cientifico do Departamento de Genética, ESALQ/USP. Piracicaba, 12: 116-121.

MIRANDA Fo, J.B., 1979. Avaliação de famỉlias de meios irmãos do segundo ciclo de seleção da população ESALQ-PB1 de milho. Relatório Científico do Departamento de Genéti ca, ESALQ/USP. Piracicaba, 13: 149-158.

MIRANDA Fo, J.B. e R. VENCOVSKY, 1979. Considerações sobre - tamanho efetivo populacional para a introdução de germo plasmas. Relatório Cientifico do Departamento de Genéti$c a$, ESALQ/USP. Piracicaba, 13: 180-189.

MIRANDA Fo, J.B. e R. VENCOVSKY, 1984. Analysis of diallel crosses among open-pollinated varieties of maize (zea mays L.). Maydica, 29: 217-234.

MOCK, J.J. e S.H. SCHUETZ, 1974. Inheritance of tasse 1 branch number in maize. Crop Sci., 14: 885-898.

MOLL, R.H., W.S. SALHUAYRA e H.F. ROBINSON, 1962. Heterosis and genetic diversity in variety crosses of maize. Crop sci., 2. 197-198.

MOLL, R.H. e H.F. ROBINSON, 1966. Observed and expected response in four selection experiments in maize. Crop sci., 6: 319-323. 
MOLL, R.H. e C.W. STUBER, 1971. Comparisons of response of to alternative selection procedures initiated with two populations of maize (Zea mays L.). Crop Sci., 11: 706711 .

MOLL, R.H. e O.S. SMITH, 1981. Genetic variances and responses in an advanced generation of a hybrid of widely divergent populations of maize. Crop Sci., 21: 387-391.

MORO, J.R., V. NASPOLINI FILHO, R.T.VIANA e E.E.G. GAMA, 1981. Introdução de novos germoplasmas de milho no Brasil. $\underline{P A B}, 16$ : 867-882.

MOTA, M.G., 1974. Comportamento de progênies de meios irmãos e $S_{1}$ na variedade de milho Centralmex. Piracicaba, ESALQ/USP, 73 p. (Dissertação de Mestrado).

NELSON, M.G., 1972. The use of exotic germplasm in pratical corn breeding programs. Proc. of the $27^{\text {th }}$ Hybrid Corn Ind. Res. Conf., 27: 115-118.

OBILANA, A.T. e A.R. HALlAUER, 1974. Estimation of variability quantitative traits in BSSS by using unselected maize inbreed 1ines. Crop Sci., 14: 99-103.

OBILANA, A.T. e A.R. HALLAUER, 1977. Comparisons of estimates of genetic variability in Iowa Stiff Stalk Synthetic of maize. Maydica, 22: 159-172.

OBLINANA, A.T., A.R. HALlAUER e O.S. SMITH, 1979. Estimated genetic variability in a maize interpopulation. The $J$. of Heredity, 70: 127-132. 
PATERNIANI, E. e J.H. LONNQUIST, 1963. Heterosis in interracial crosses of corn (Zea mays L.). Crop Sci., 3: $504-507$.

PATERNIANI, E., 1967. Selection among and within half-sib families in a brazilian populations of maize (zea mays L.) Crop Sci., 7: 212-216.

PATERNIANI, E., 1968. Avaliação do método de seleção entre e dentro de familias de meios irmãos no melhoramento do milho (Zea mays L.). Piracicaba, ESALQ/USP, 92 p. (Tese para cargo de Professor Catedrático).

PATERNIANI, E., J.R. ZINSLY e J.B. MIRANDA Fo, 1977. Popu1 ações melhoradas de milho obtidas pelo Instituto de Gené tica. Rezatório Cientificc do Departamento de Genética, ESALQ/USP. Piracicaba, 11: 108-114.

PATERNIANI, E. e M.M. GOODMAN, 1977. Races of maize in Brazil and adjacent areas. In: International Maize and Wheat Improvment, Mexico, $95 \mathrm{p}$.

PATERNIANI, E., 1981. Influence of tassel size on ear placement in maize (Zea mays L.). Maydica, 26: 85-91.

PETERSON, C.E。, 1975. Plant introduction in the improvment of vegetable cultivars. Hortscience, 10: 575-579.

QUEIROZ, M.A., 1969. Correlações genéticas e fenotípicas em progênies de meios irmãos em milho (Zea mays L.) e suas implicações no melhoramento.Piracicaba, ESALQ/USP, 71 p. (Dissertação de Mestrado). 
RAMALHO, M.A.P., 1977. Eficiência relativa de alguns proces sos de seleção intrapopulacional no milho baseados em famỉlias não endögamas. Piracicaba, ESALQ/USP, 122 p. (Tese de Doutorado).

RAMIREZ, R., D.H. TIMOTHY, E.B. DIAZ, U.J. GRANT, G.E.N. GAL LE, E. ANDERSON e W.L. BROWN, 1960. Races of maize in Bolivia. Washington, National Academy of SciencesNational Research Council. Publication n? 747.

RISSI, R., 1980. Estimação de parâmetros genéticos em duas sub-populações da variedade de milho (Zea mays L.) Piranão. Piracicaba, ESALQ/USP, 87 p. (Dissertação de Mestra do).

ROBINSON, H.F., R.E. COMSTOCK e P.H. HARVEY, 1949. Estimates of heritability and degree of dominance in corn. Agron. J., 41: $353-359$.

ROBINSON, H.F., R.E. COMSTOCK e P.H. HARVEY, 1951. Genotypic and phenotypic correlations in corn and their implications in selection. Agron. J., 43: 282-287.

ROBINSON, H.P., R.E. COMSTOCK e P.H. HARVEY, 1955. Genetic variances in open pollinated varieties of corn. Genetics, 40: $45-60$.

ROBERTS, L.M., U.J. GRANT, R.E. RAMIREZ, W.H. HATHAWAY, D.L. SMITH e P.C. MANGELSDORF, 1957. Races of maize in Colombia. Washington, National Academy of SciencesNational Research Council. Publication no 510. 
SAWAZAKI, E., 1979. Treze ciclos de seleção entre e dentro de familias de meios irmãos para produção de grãos no mi1ho IAC Maya. Piracicaba, ESALQ/USP, 99 p. (Dissertação de Mestrado).

SCHOENER, C.S。 e W.R. FEHR, 1979. Utilization of plant introductions in soybean breeding populations. Crop Sci., 19: 185-188.

SENTZ, J.C., 1971. Genetic variance in a synthetic variety of maize estimated by two mating designs. Crop Sci., 11: $234-238$.

SHAUMAN, W.L., 1971. Effect of incorporation of exotic germplasm on the genetic variance components of an adapted open-pollinated corn variety at two plant populations densities. Nebraska, Lincoln, 93 p. (PhD. Dissertation).

SHEHATA, A.H. e N.L. DRAWN, 1975. Genetic analysis of grain yield in maize as manifested in genetically diverse varietal populations and their crosses. Egypt. J. Genet. Cytol., 4 : 90-116.

SILVA, J.C. e A.R. HALLAUER, 1975. Estimation of epistatic variance in Iowa Stiff Stilk Synthetic maize. J. Heredity, 66: $290-296$.

SMITH, D.C., 1967. Development and sucess in plant breeding. In: Plant Breeding. $\Lambda$ Symposium Held at Iowa State University. Ed. by K.J. Frey. The Iowa State University Press, Ames, Iowa, 430 p. 
SOUZA JUNIOR, C.L., I.0. GERALDI e J.R. ZINSLY, 1980. Corre 1 ações genéticas e fenotípicas entre seis caracteres de população de milho (zea mays L.) Suwan. Relatório Cientí fico do Departamento de Genética, ESALQ/USP. Piracicaba, 14: $146-152$.

SOUZA JUNIOR, C.L., 1983. Variabilidade genética em milho (Zea mays L.) e relações com a seleção recorrente intra e interpopulaciona1. Piracicaba, ESALQ/USP, 151 p. (Tese de Doutorado).

STEEL, R.G.D. e J.H. TORRIE, 1960. Principles and procedures of statistic. New York, McGraw-Hill Book Company, 481 p.

STEPHENS, J.C., F.R. MILLER e D.T. ROSENOW, 1967. Conversion of alien sorghum to early combine genotypes. Crop Sci., 7: 396 .

SUBANDI, W. e W.A. COMPTON, 1974. Genetic studies in an exotic population of corn (Zea mays L.) grown under two plant densities. I. Estimates of genetic parameters. Theor. Appl. Genet., 44: 153-159.

TAVARES, F.C.A., 1972. Componentes da produção relacionados à heterose em hỉbridos intervarietais de milho (Zea mays L.). Piracicaba, ESALQ/USP, 106 p. (Dissertação de Mestrado).

TIMOTHY, D.H., B.V. PENA, R.E. RAMIREZ, W.L. BROWN e E. ANDERNESON, 1961. Races of maize in Chile. Washington, National Academy of Sciences-National Research Council. Publication no 847 . 
TIMOTHY, D.H., W.H. HATHAWAY, U.J. GRANT, M.C. TORREGROZA, D.V. SARRIA e D.A. VARELA, 1963. Races of maize in Ecuador. Washington, National Academy of SciencesNational Research Council. Publication n! 975.

TIMOTHY, D.H., 1975. Considerations on the use of exotic germplasm, genetic recombination and natural selection. In: IX Congresso Internacional de Pastagens, São Paulo, 1: $175-177$.

THOMPSON, D.L., 1968. Silage yield of exotic corn. Agron. J., 60: 579-581.

THORNE, J.C. e W.R. FEHR, 1970. Exotic germplasm for yield improvment in 2-way and 3-way soybean crosses. Crop Sci., 10: 677-678.

TORRES SEGOVIA, E., 1976. Seis ciclos de seleção entre e dentro de familias de meios irmãos no milho (Zea mays L.) Centralmex. Piracicaba, ESALQ/USP, 98 p. (Tese de Douto rado).

TROYER, A.F. e W.L. BROWN, 1972. Selection for early flowering in corn. Crop Sei., 12: 301-304.

VELLO, N.A., W.R. FEHR e J.B. BAHRENFUS, 1984. Genetic variability and agronomic performance of soybean populations developed from plant introductions. Crop Sci., 24: 511-514.

VEncovsky, R., 1969. Genética Quantitativa. In: W.E. KERR, org. Melhoramento e Genética. Edições Melhoramento, p. $17-38$ 。 
VENCOVSKY, R。, 1978. Herança Quantitativa. In: E. PATERNIANI, coord. Melhoramento e Producão de Mizho no Brasiz. Ed. Marprint. p. 122-201.

VERA, G.A。 e P.L. CRANE, 1970. Effects of selection for lower ear height in synthetic populations of maize. Crop Sci., 10: 286-288.

WEBEL, O.D. e J.H. LONNQUIST, 1967. An evaluation of modified ear-to-row selection in a population of corn (2 ea mays, L.). Crop sci., 7: 651-655.

WELLHAUSEN, E.J., L.M.ROBERTS, E.X. HERNANDEZ e P.C. MANGELSDORF, 1952. Races of maize in Mexico. Bussey Inst. Harvard Univ. Press, Cambridge.

WELLHAUSEN, E.J., 1956. Improving american corn with exotic germplasm. Proc. of the $11^{\text {th }}$ Hybrid Corn Ind. Res. Conf., 11: $85-96$.

WEllhauSEN, E.J., A.O.FUENTES, A.C. HERnADEZ E. P.C. MANGELSDORF, 1957. Races of maize in Central America. Washington, National Academy of Sciences-National Research Council. Publication ne 511 .

WELLHAUSEN, E.J., 1965. Exotic germ plasm for improvment of corn belt maize. Proc. of the $20^{\text {th }}$ Hybrid Corn Ind. Res. Conf., 20: 11-45.

WHITE, R.0., 1963. The conservation of wild species. Gen. Agraria, 17: 388-402. 
WILLIAMS, J.C., L.H. PENNY e C.F. SPRAGUE, 1965. Fu11 sib and half sib estimates of genetic variance in an openpollinated variety of corn. Crop Sci., 5: 125-129.

ZINSLY, J.R., 1969. Estudo comparativo entre a seleção massal e a seleção entre e dentro de famỉilas de meios irmãos em milho (Zea mays L.). Piracicaba, ESALQ/USP, 89 p. (Tese de Doutorado).

ZOHARY, D., 1973. Gene pools for plant breeding. In: Agricultural Genetics-Selected Topics. Jerusalen, Ed. Rom.Noav。, Department of Genetics, p. 177-183.

ZUBER, M.S., 1975. Corn germplasm base in the United States: Is it narrowing, widening, or static? Proc. of the $30^{\text {th }}$ Hybrid Corn Ind. Res. Conf., 30: 277-286.

ZUBER, M.S., 1980. 1979 U.S. corn germplasm base. Proc. of the $35^{\text {th }}$ Hybrid Corn Ind. Res. Res. Conf., 35: 234-249. 
.139.

T A B E L A S 
.140.

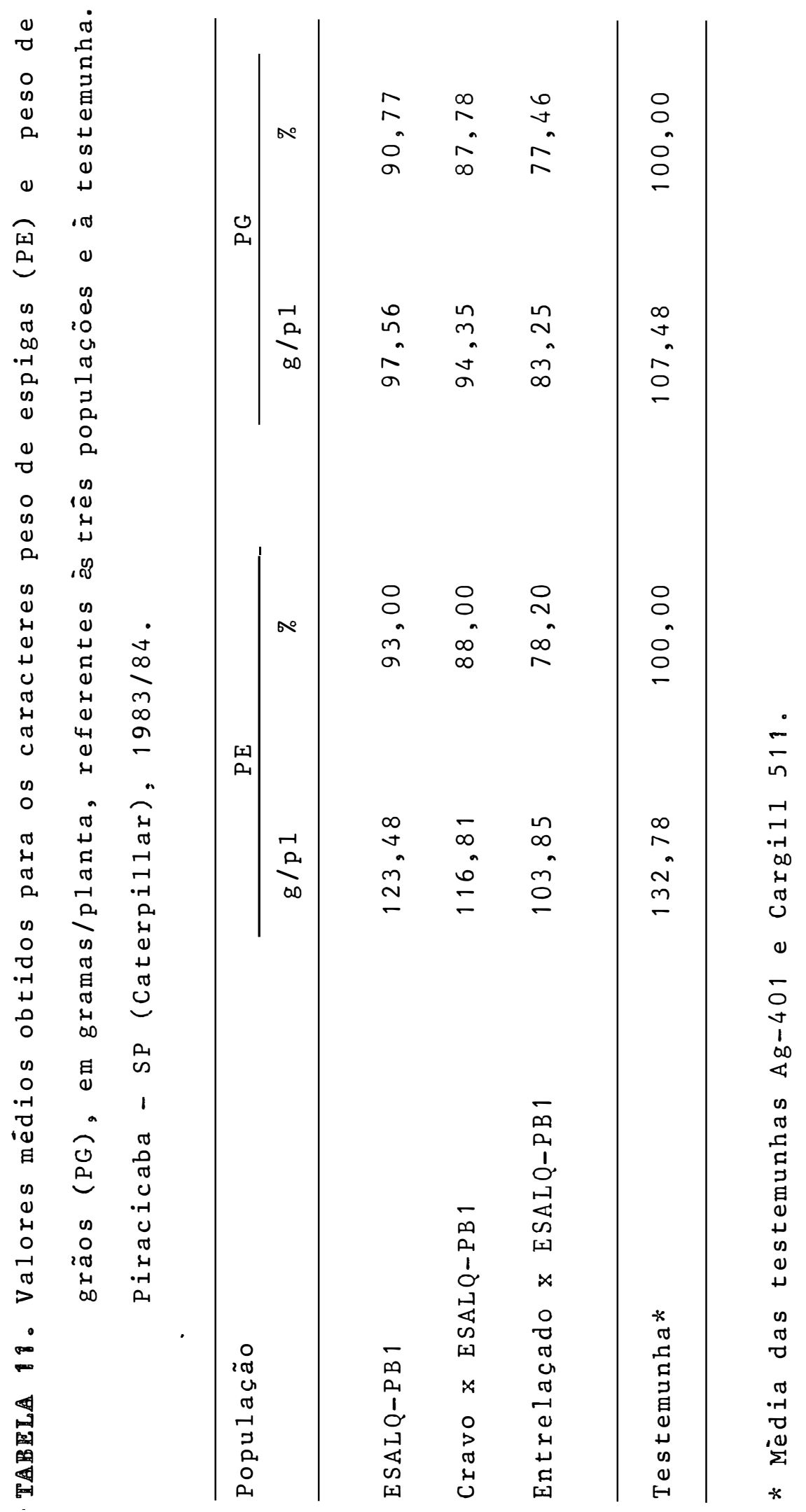




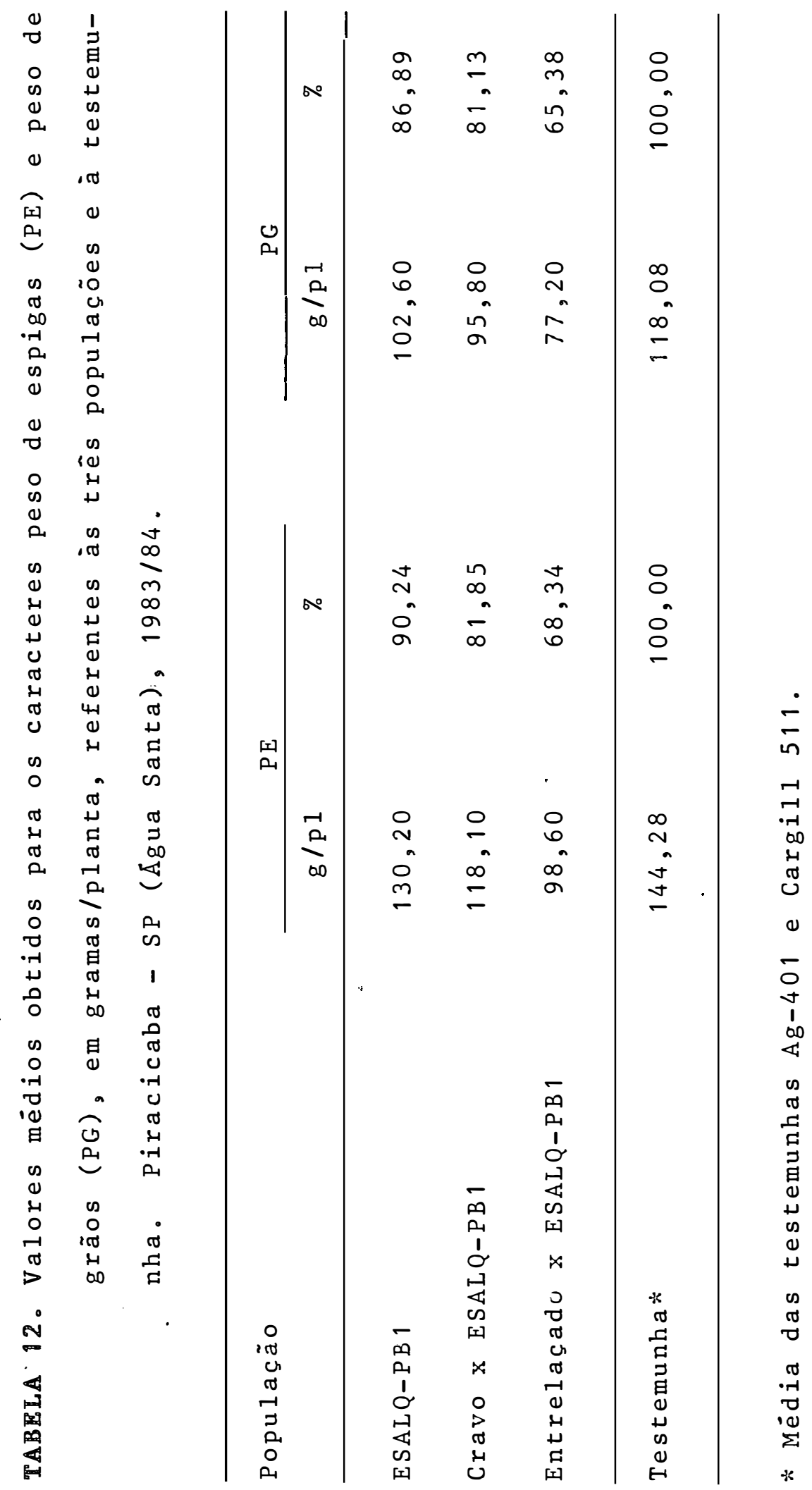


.142.

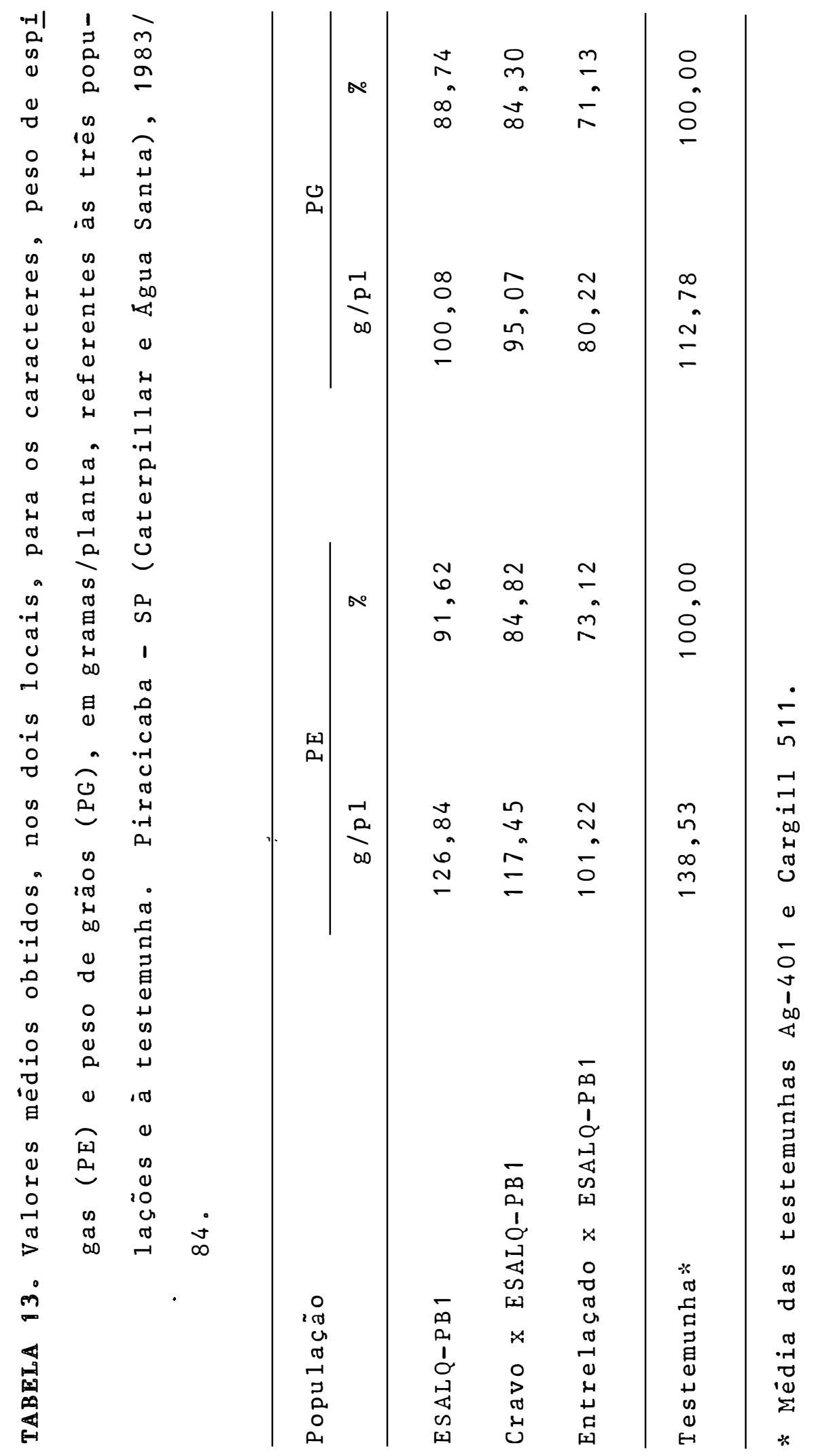


.143.

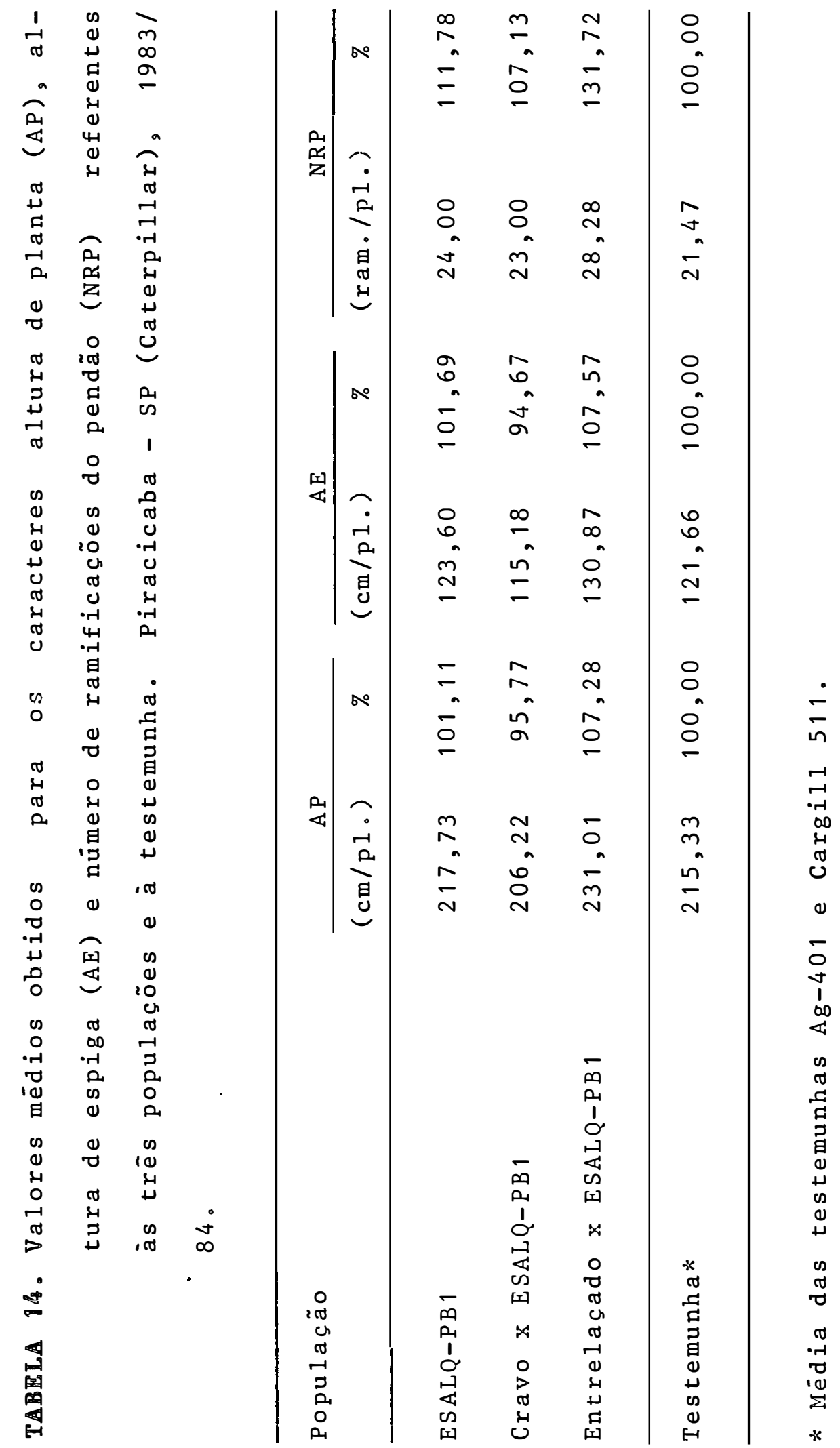


.144.

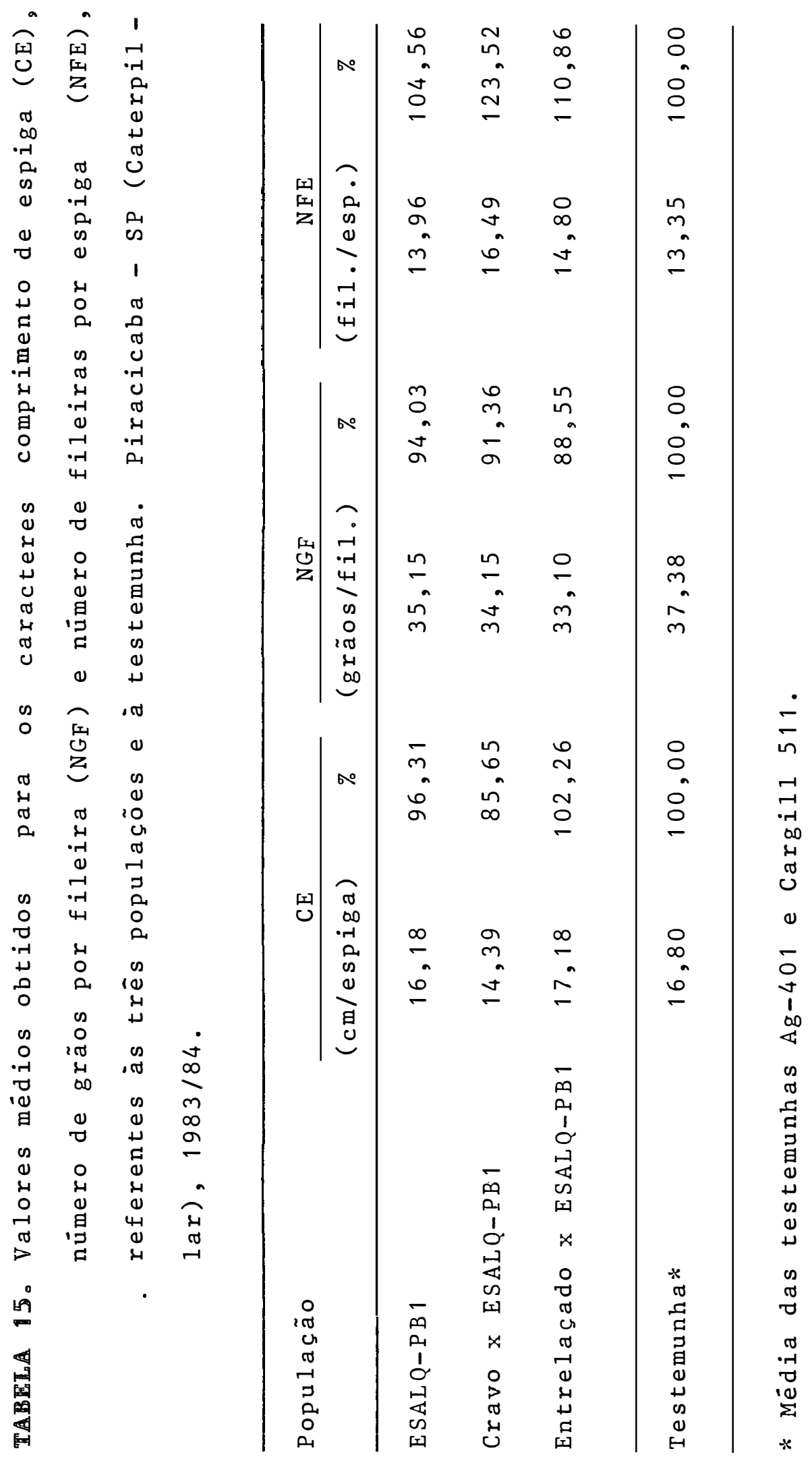


.145.

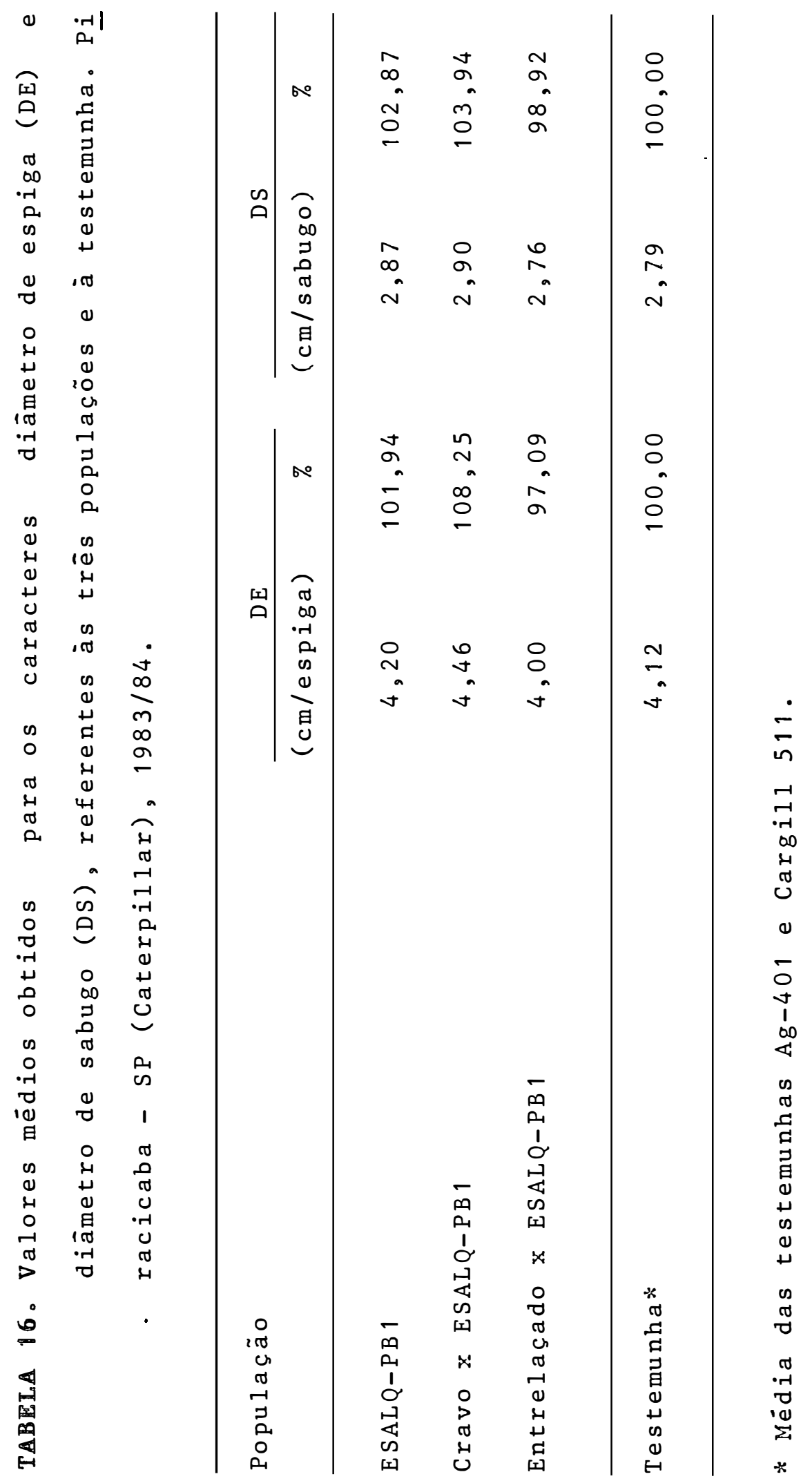


.146.

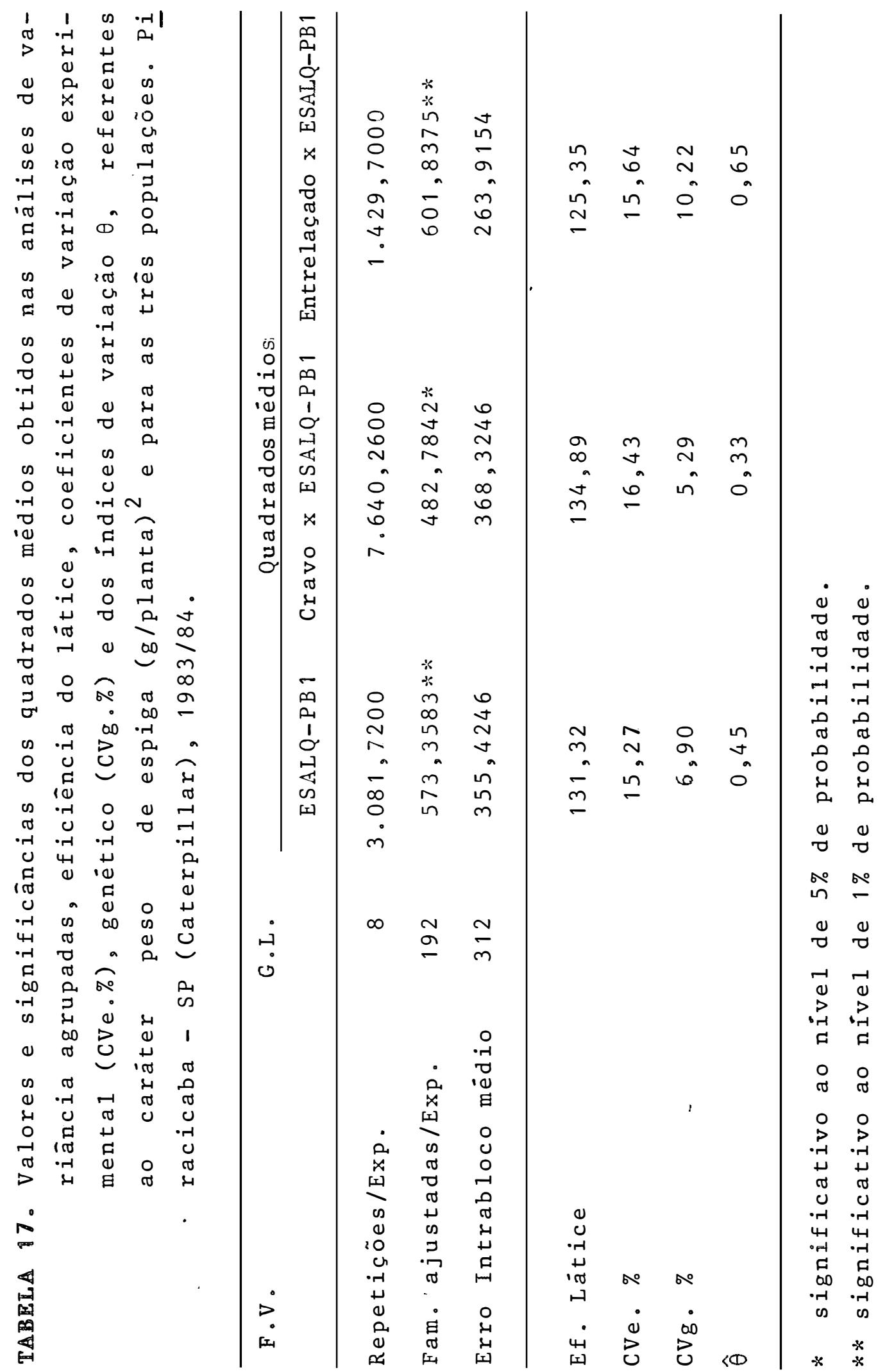


.147.

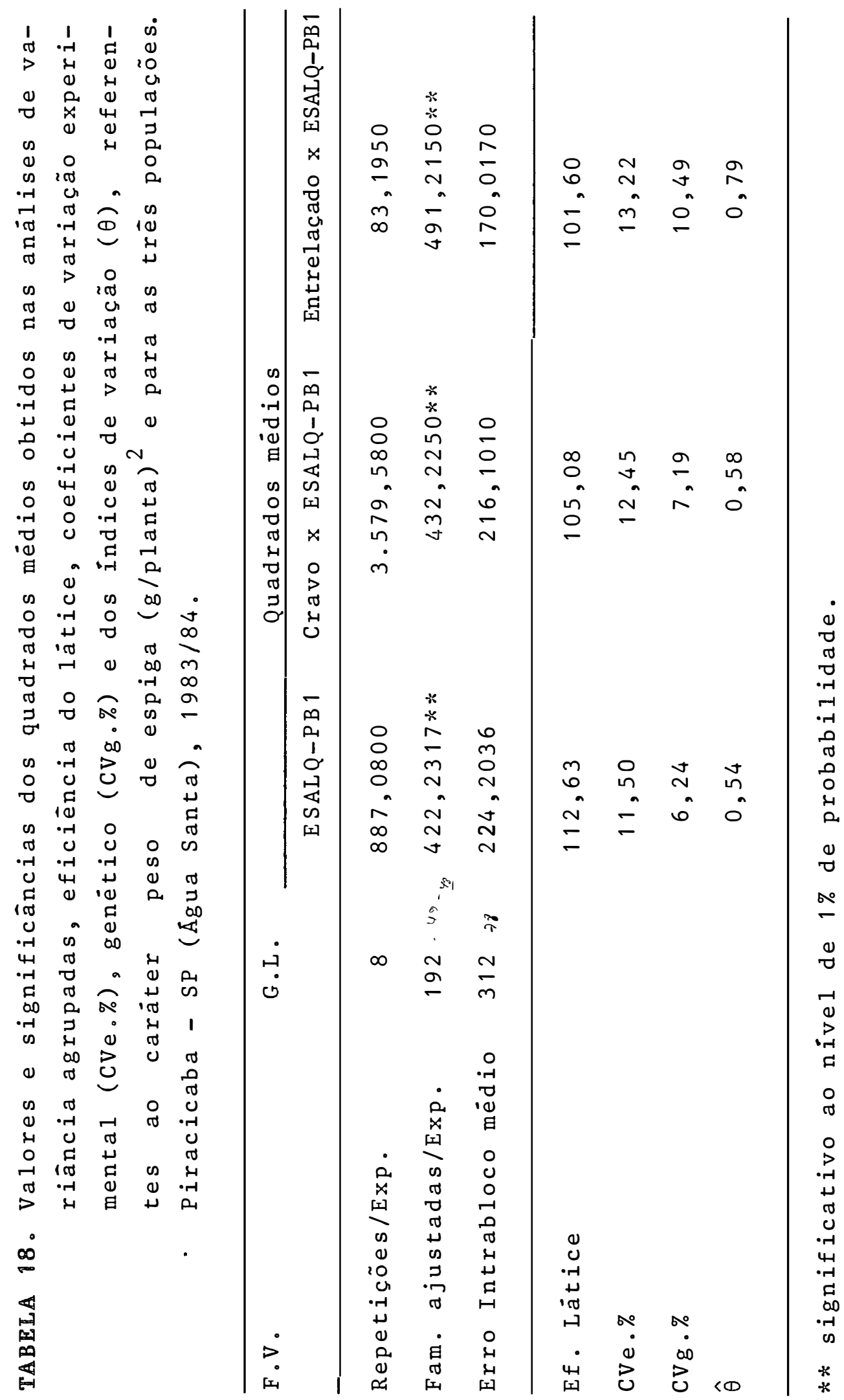


.148.

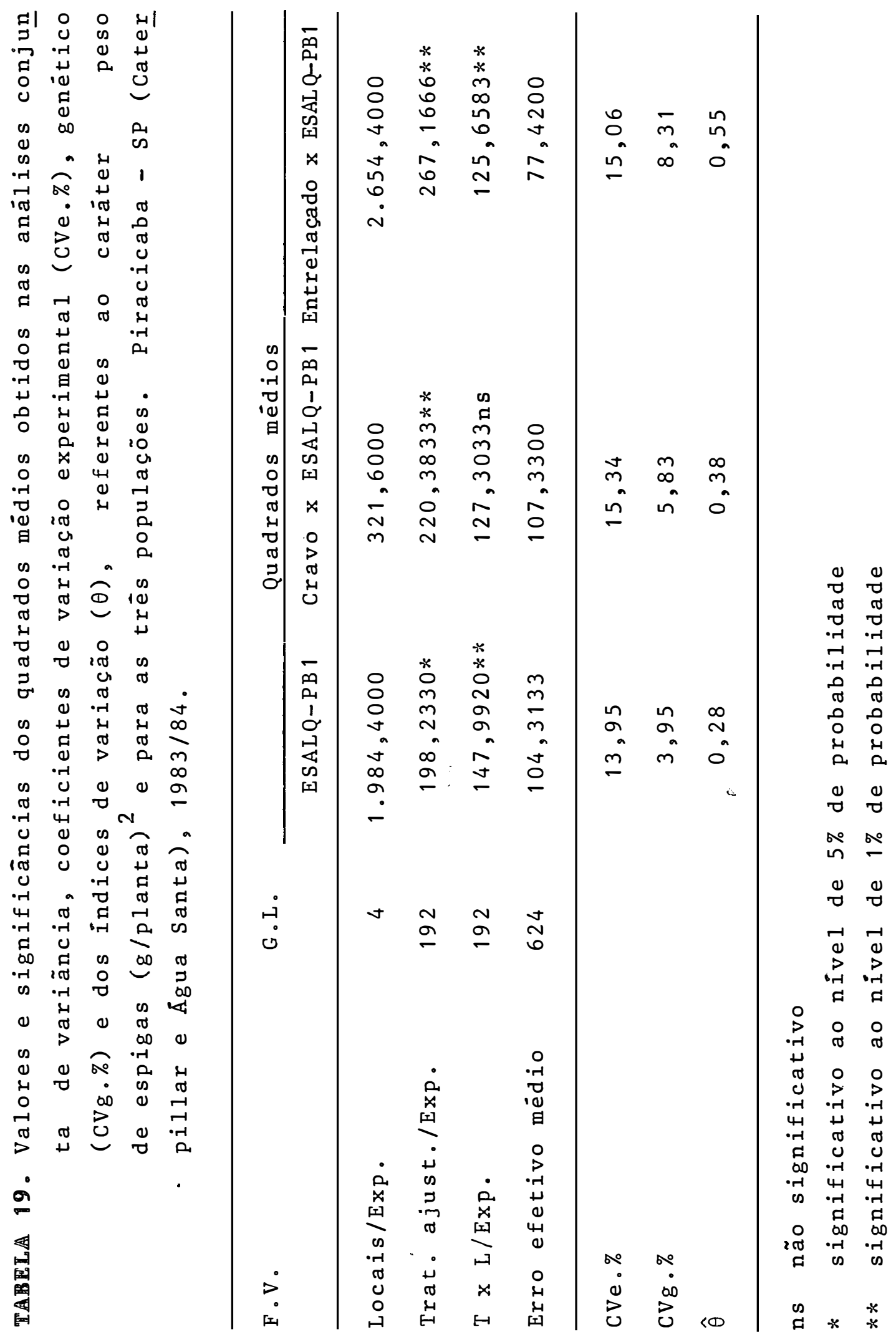


.149.

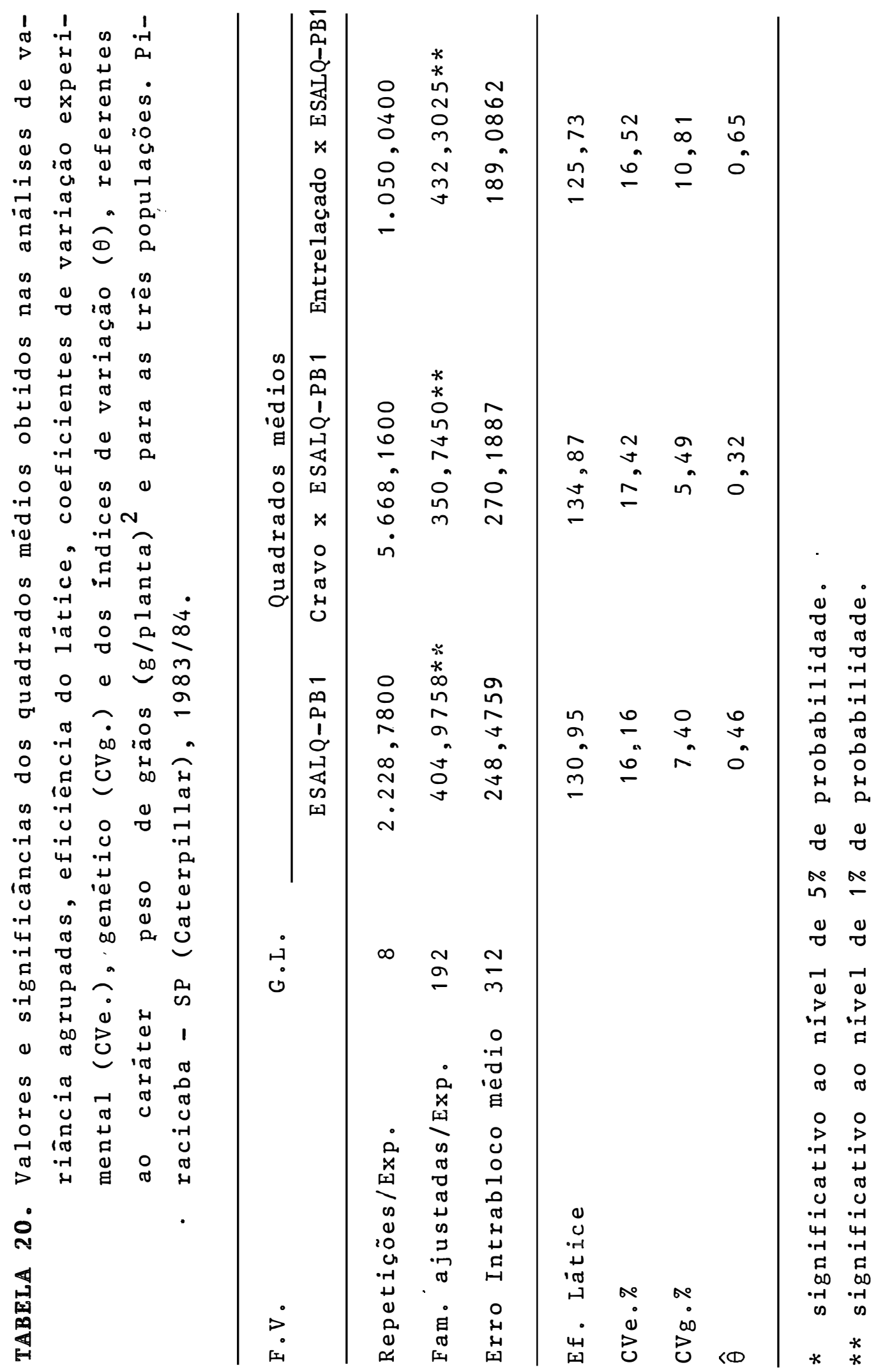


.150.

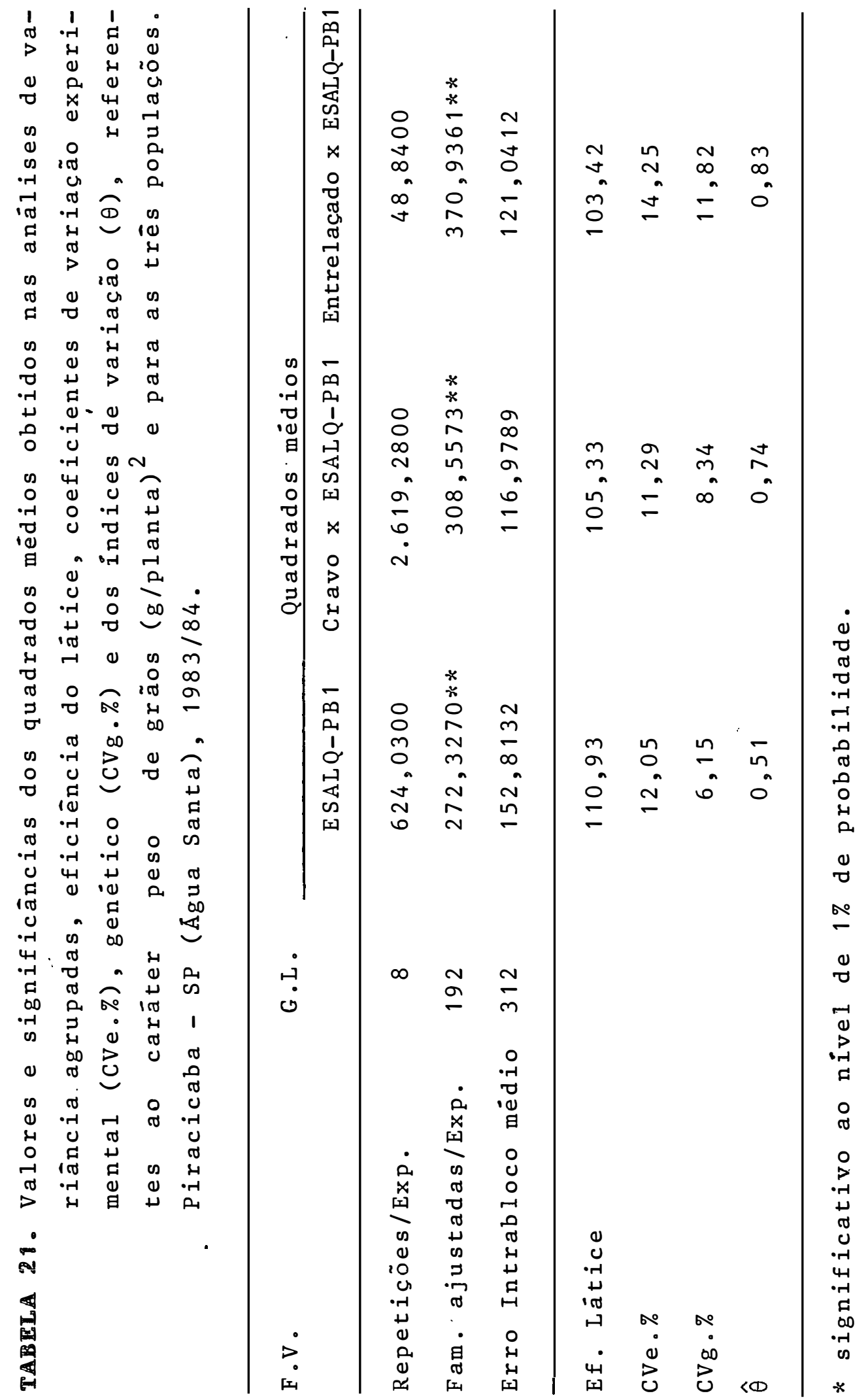


.151.

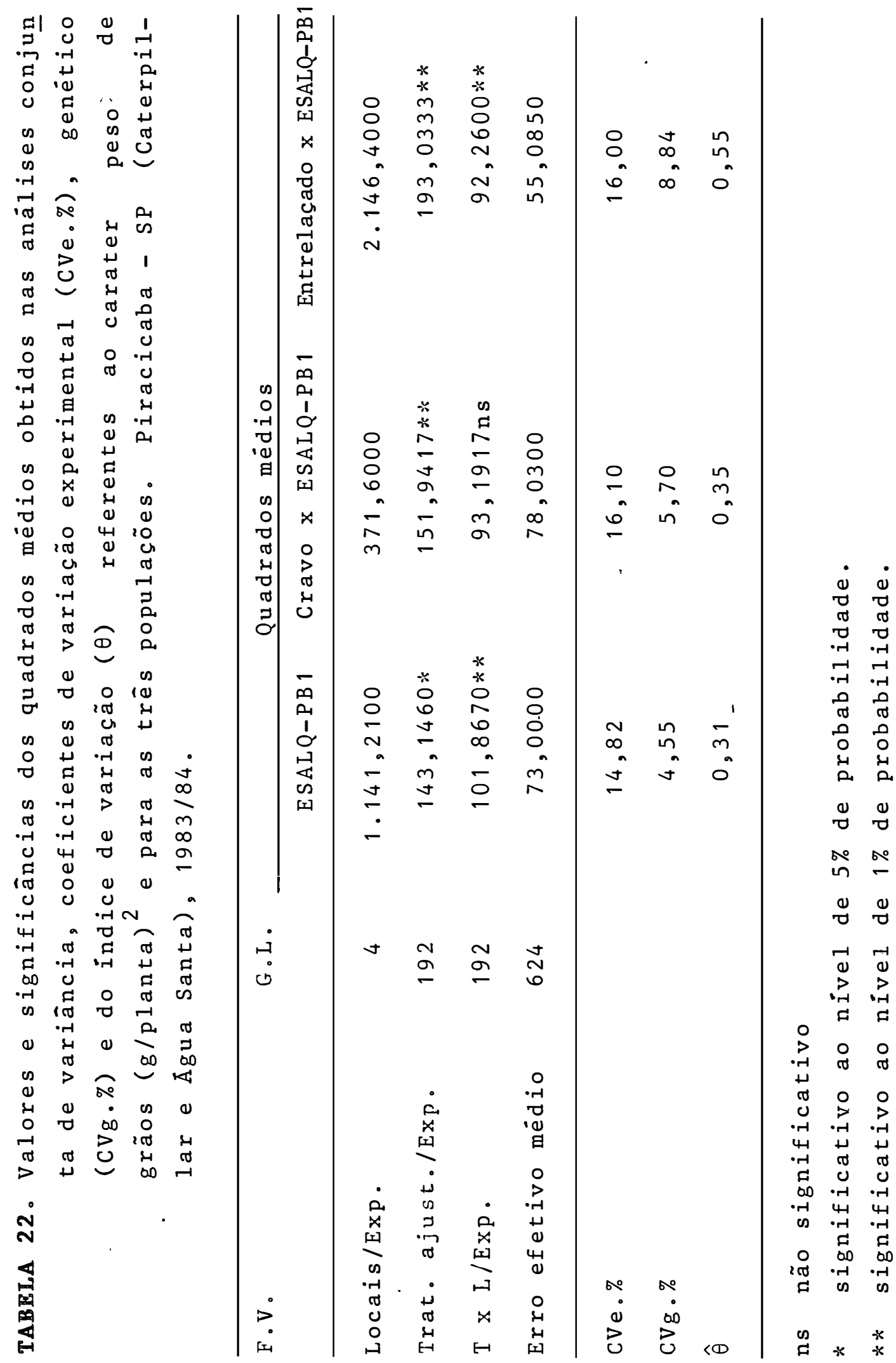




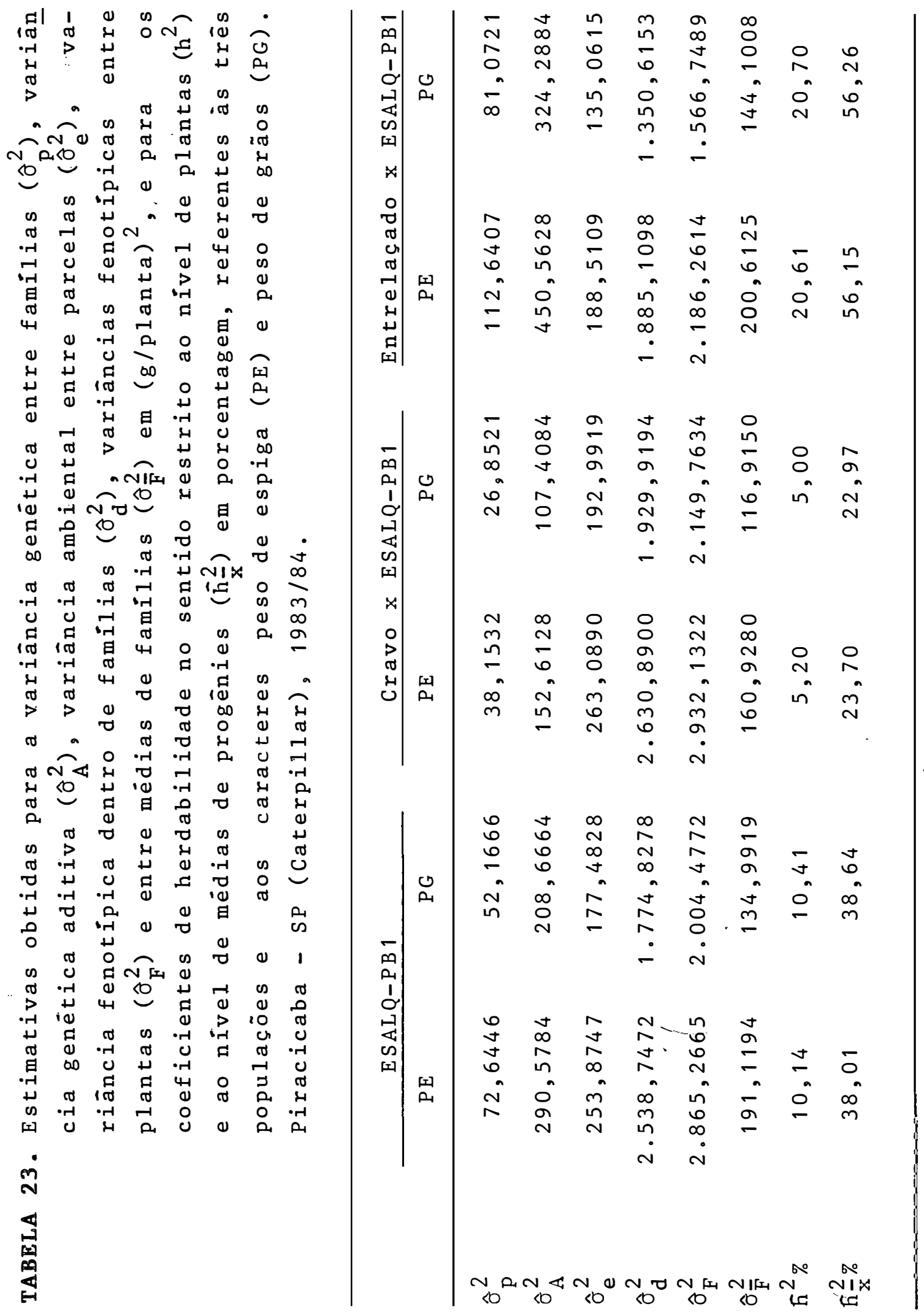



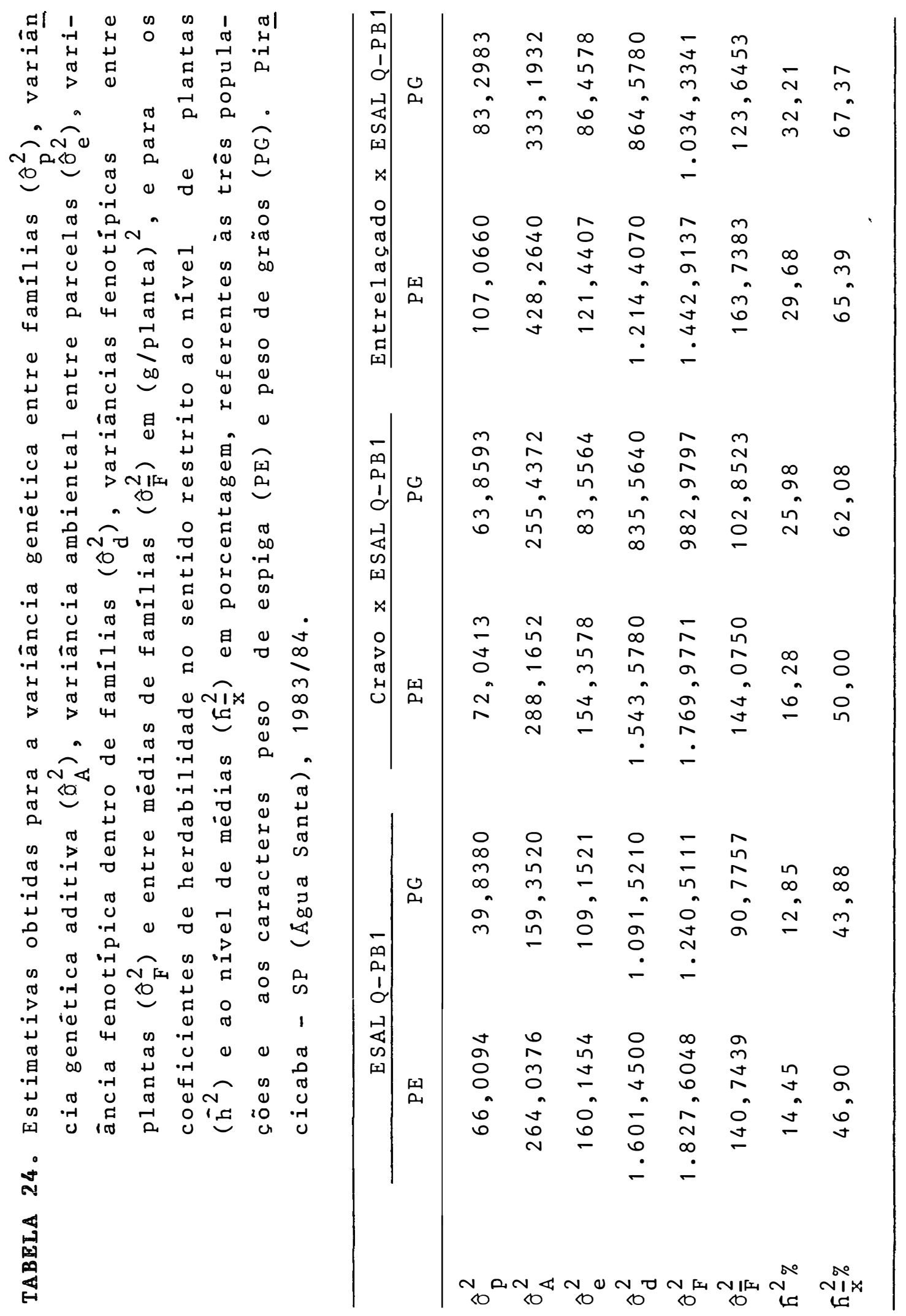


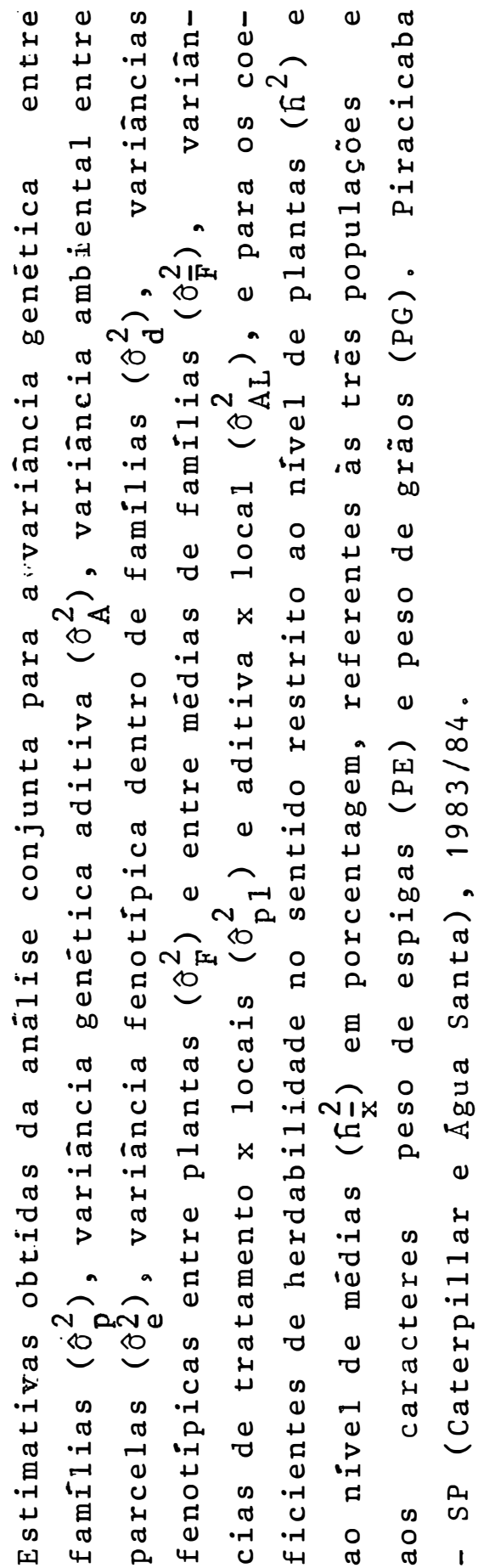

กิ

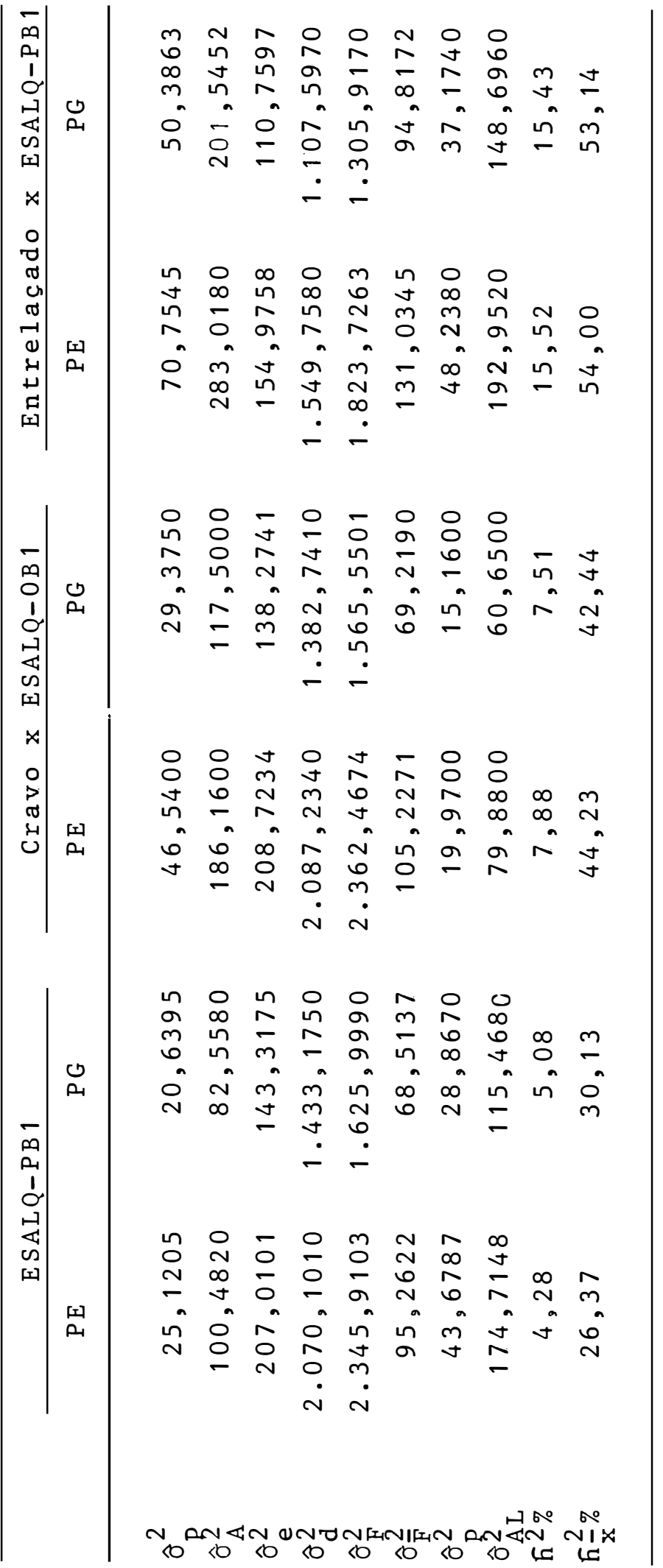




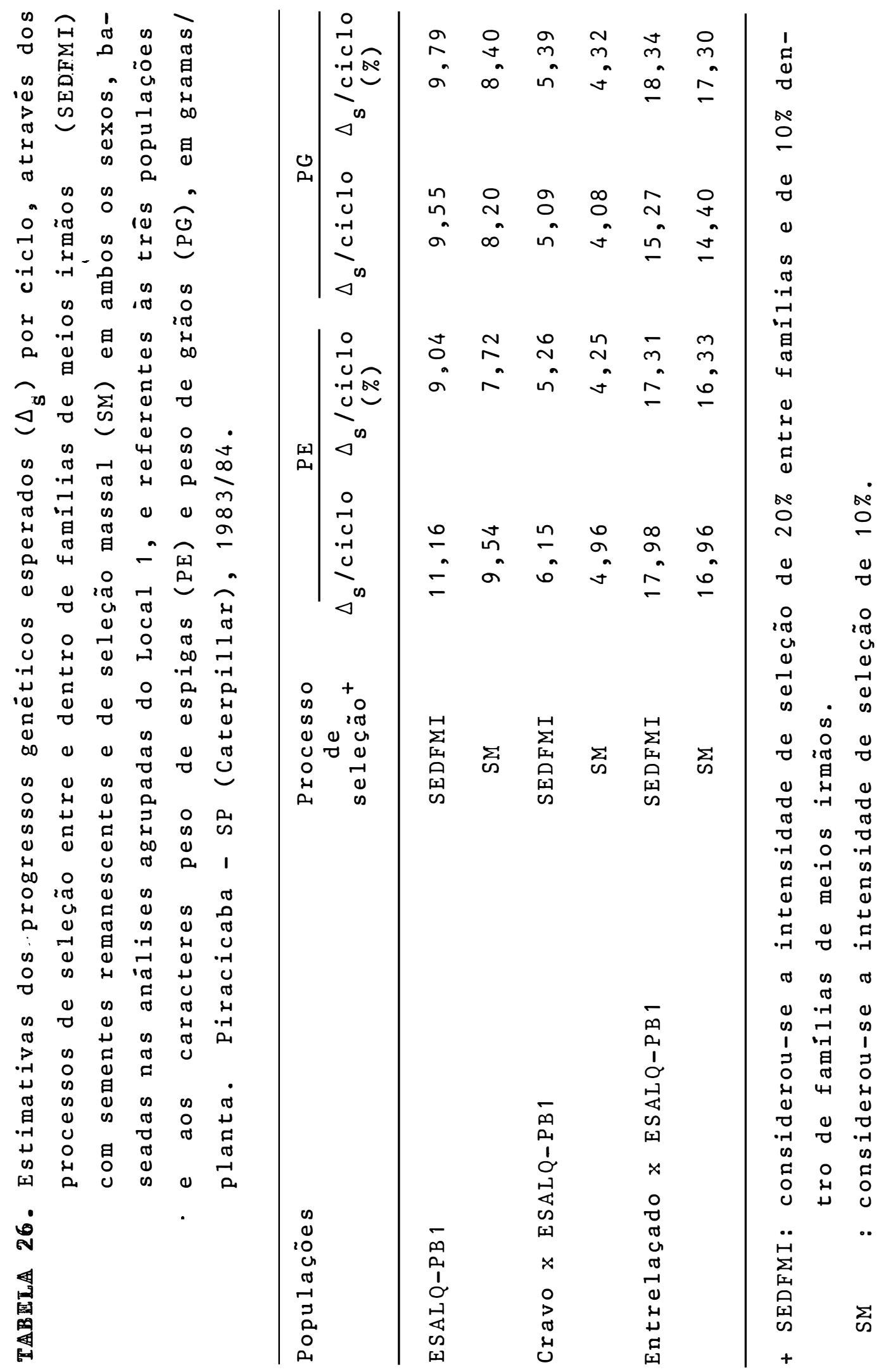




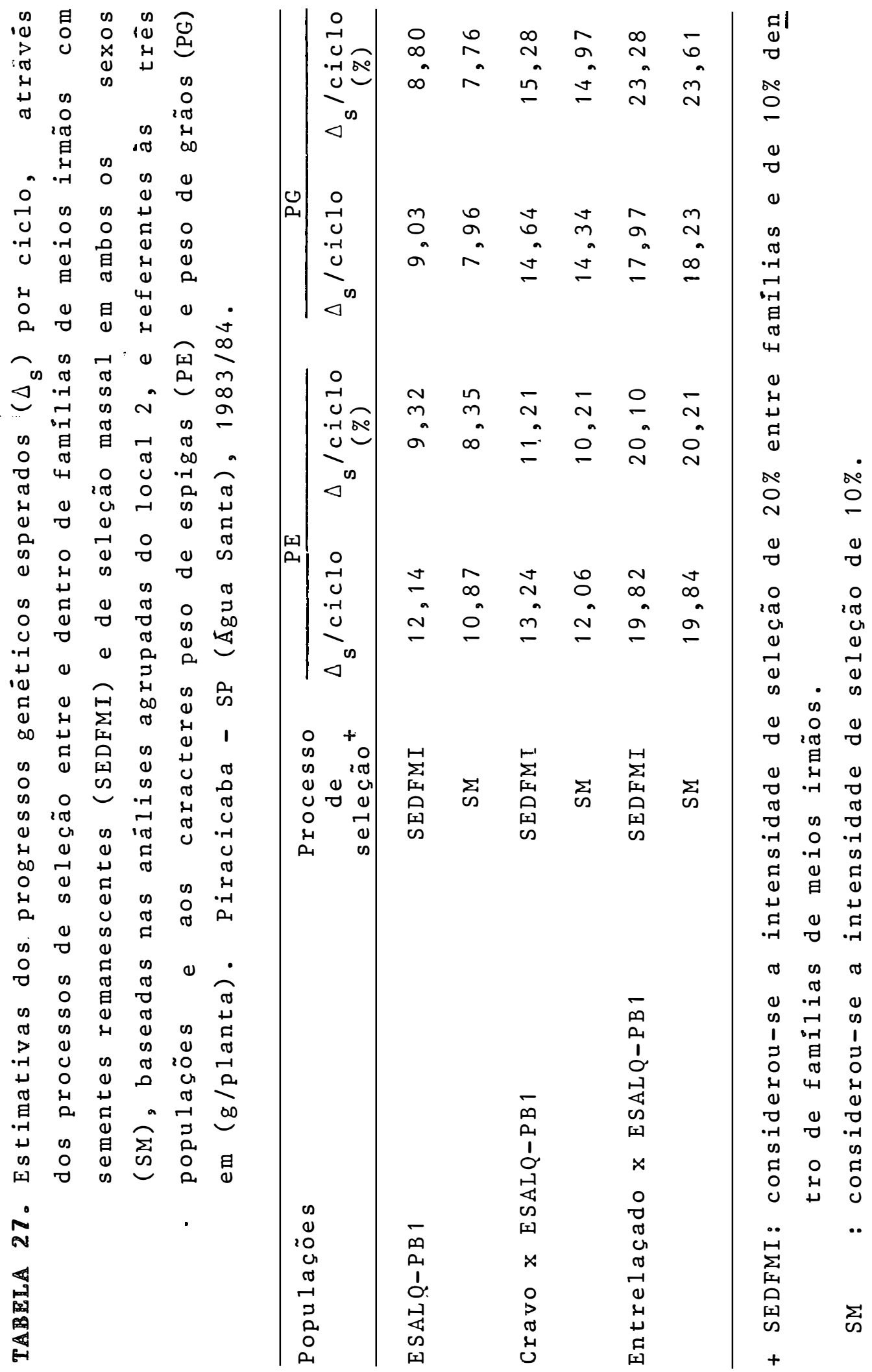


.157.

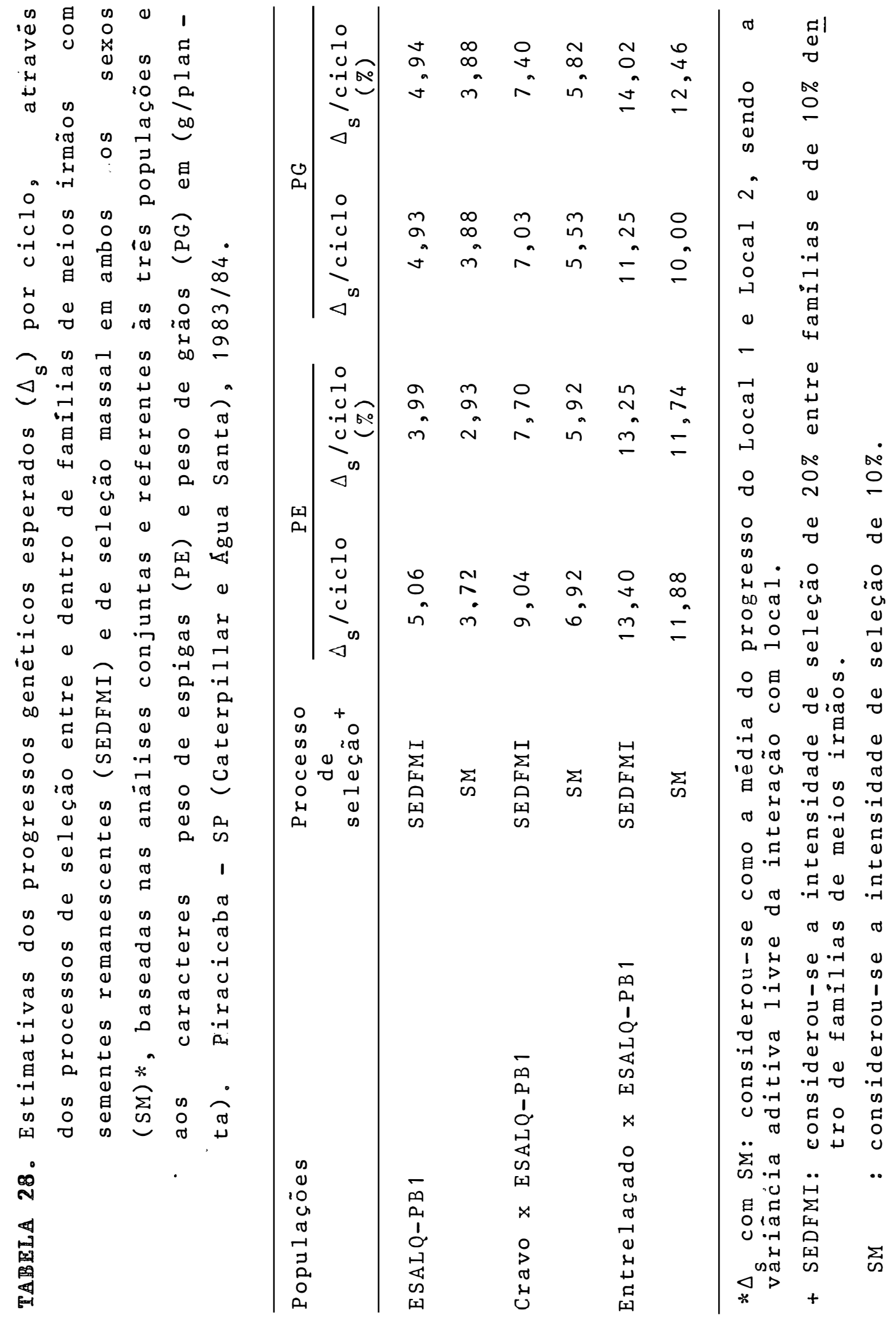


.158.

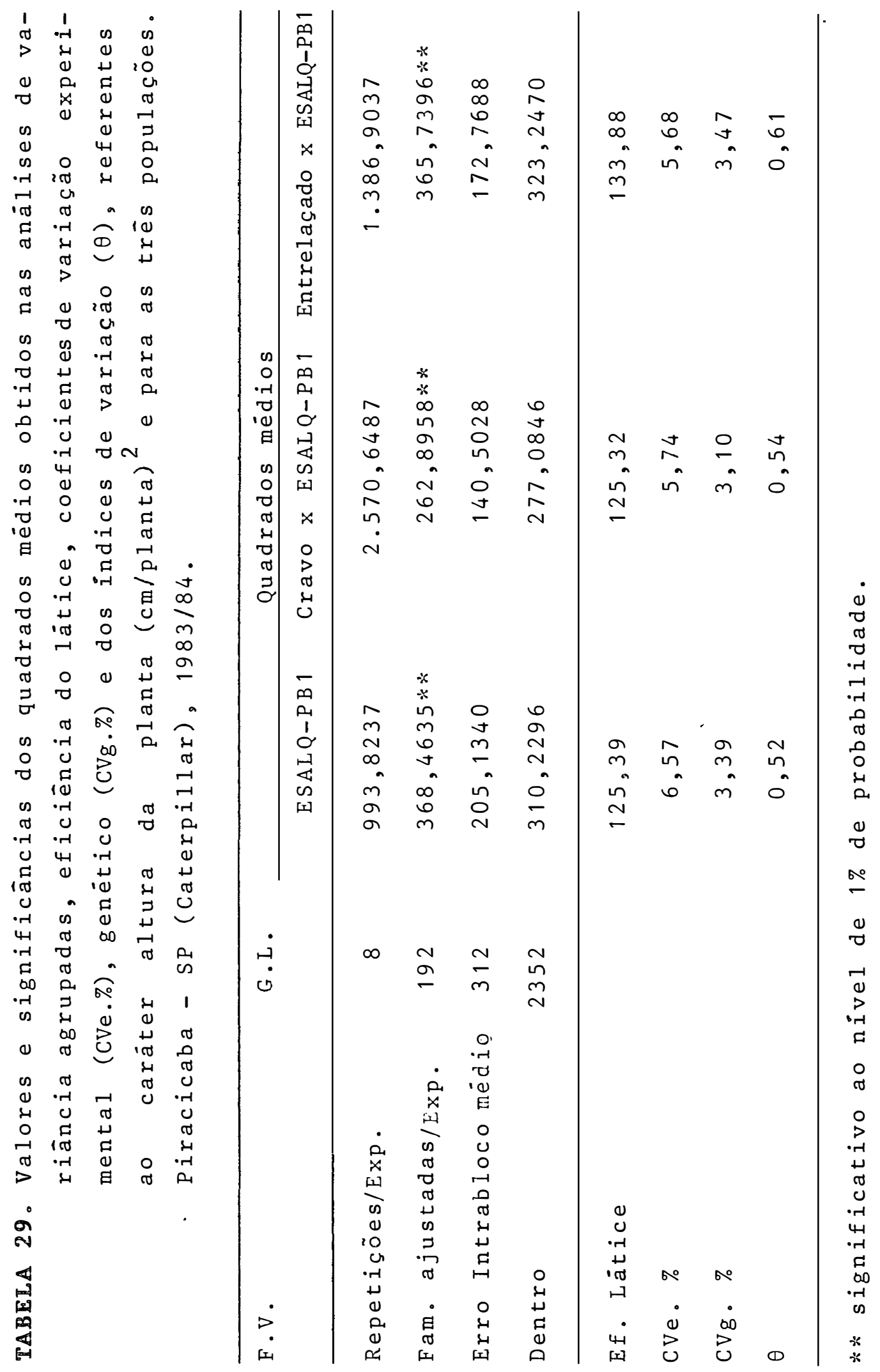




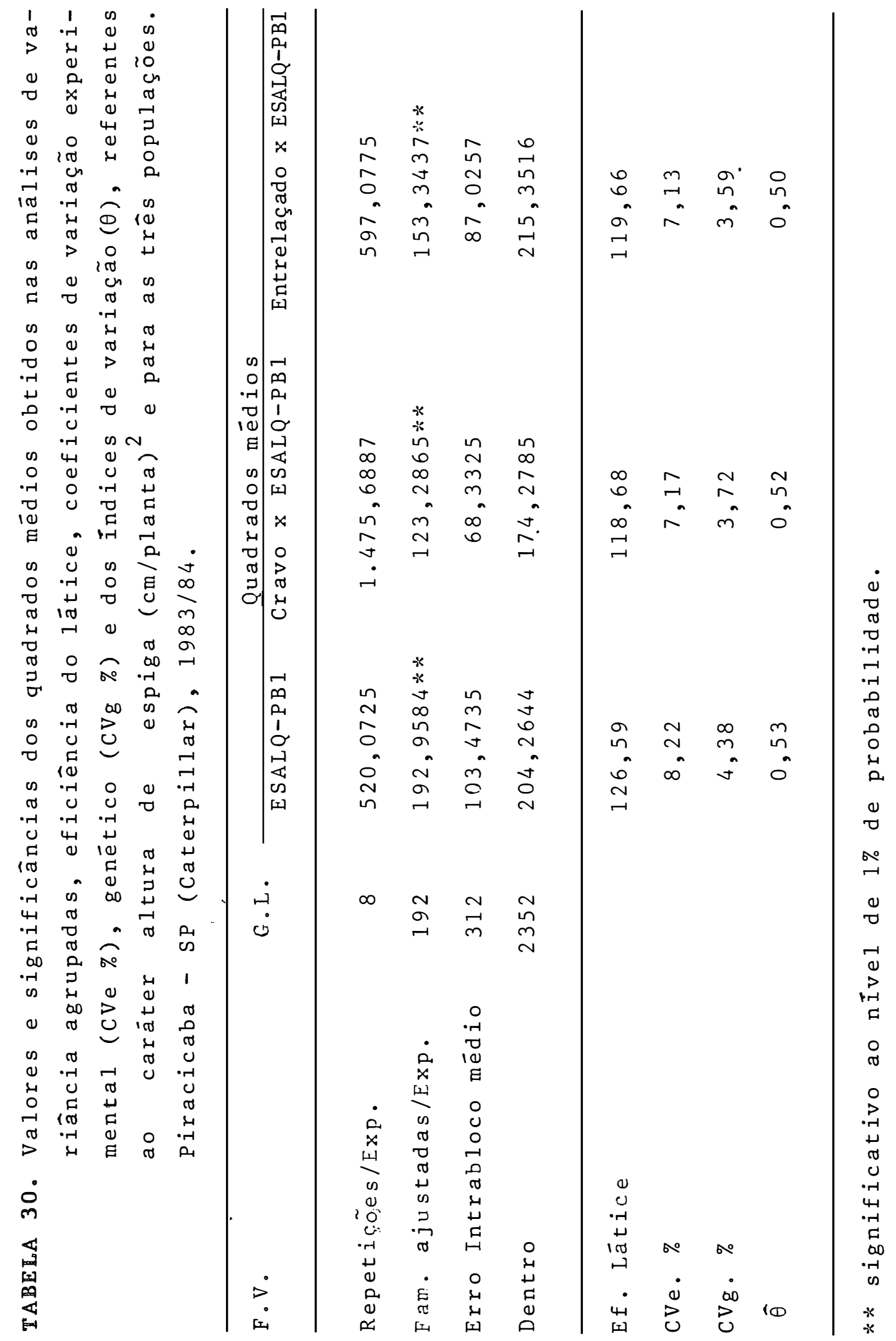


.160.

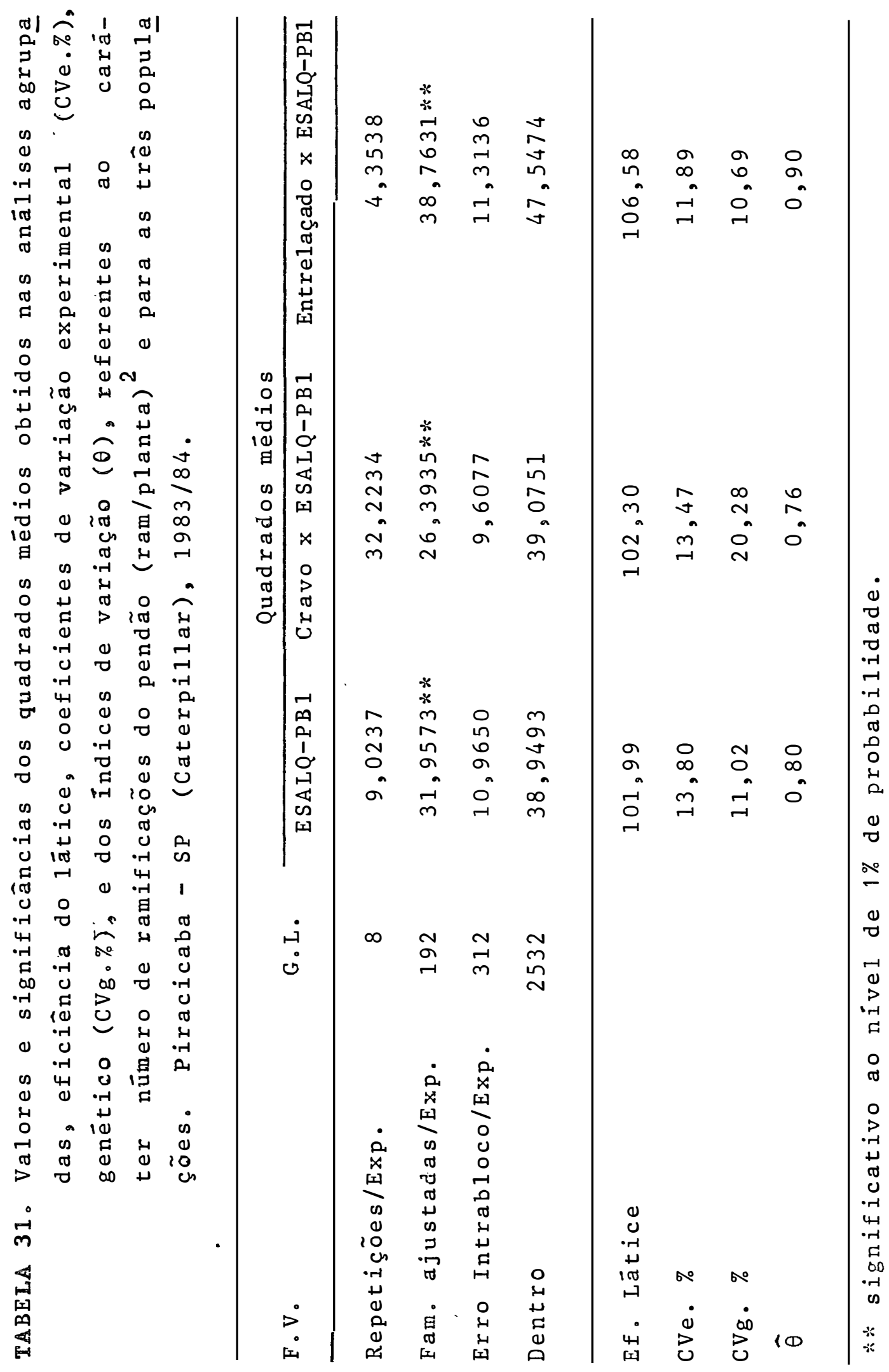


.161.

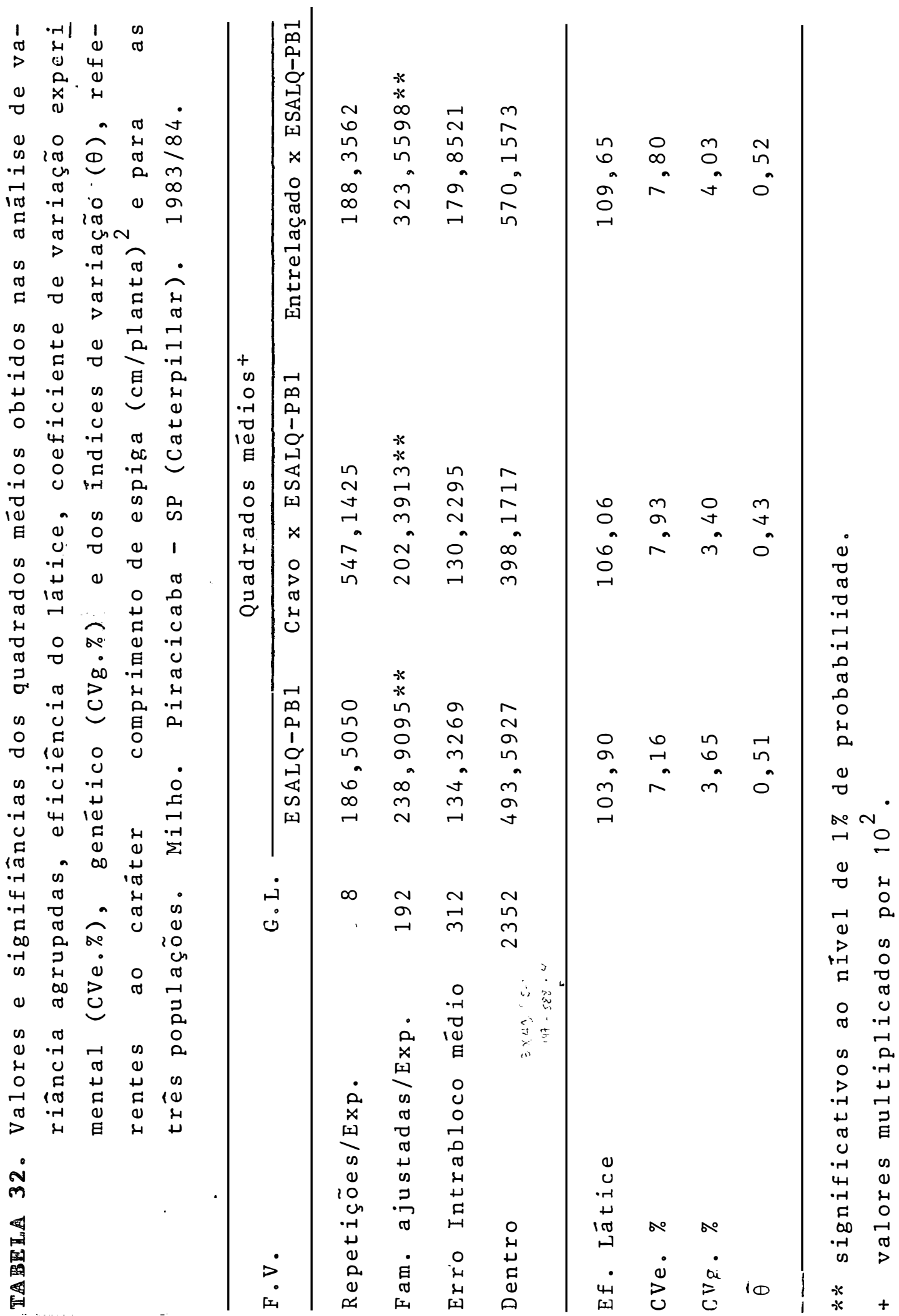


.162.

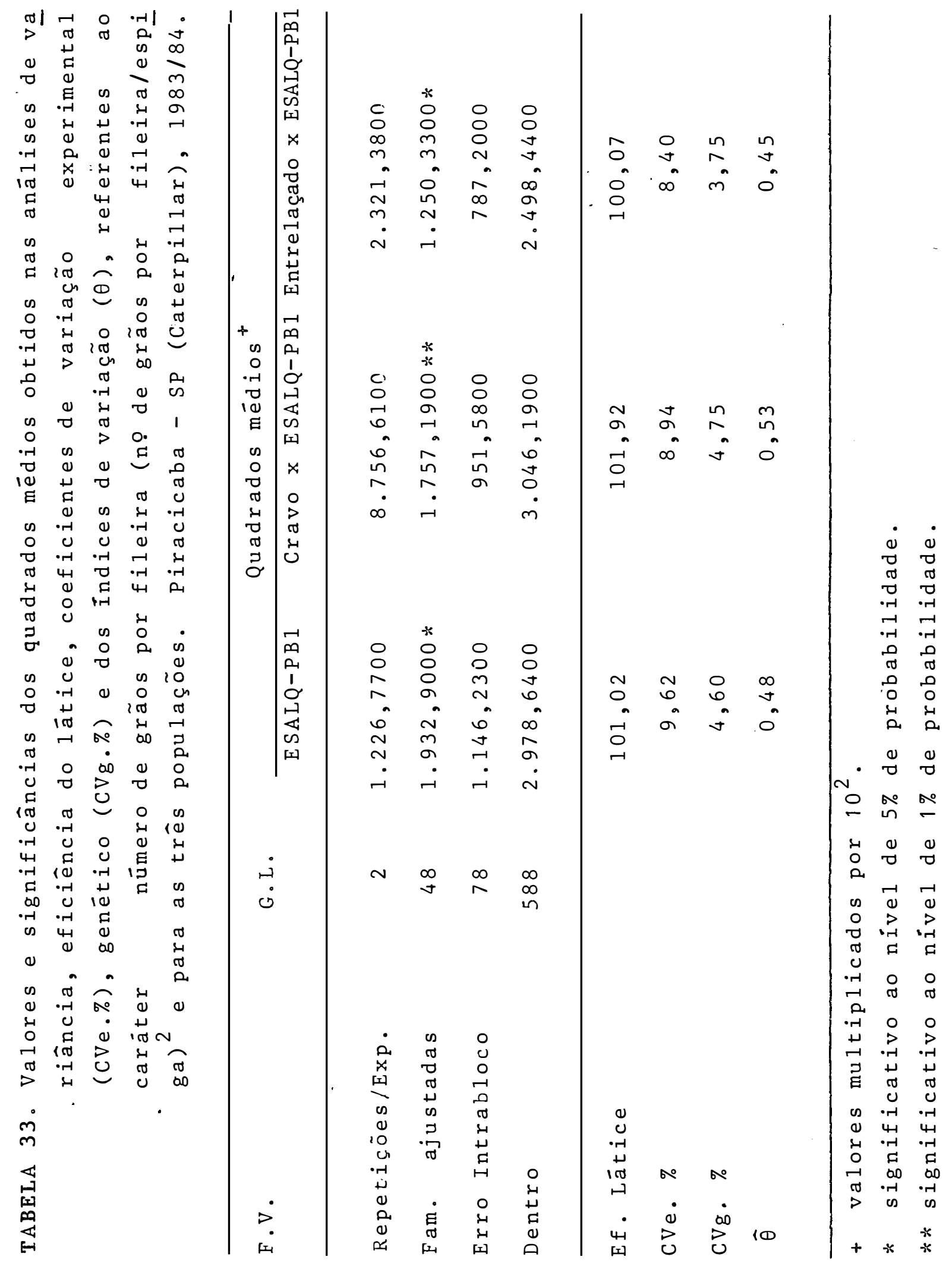


.163.

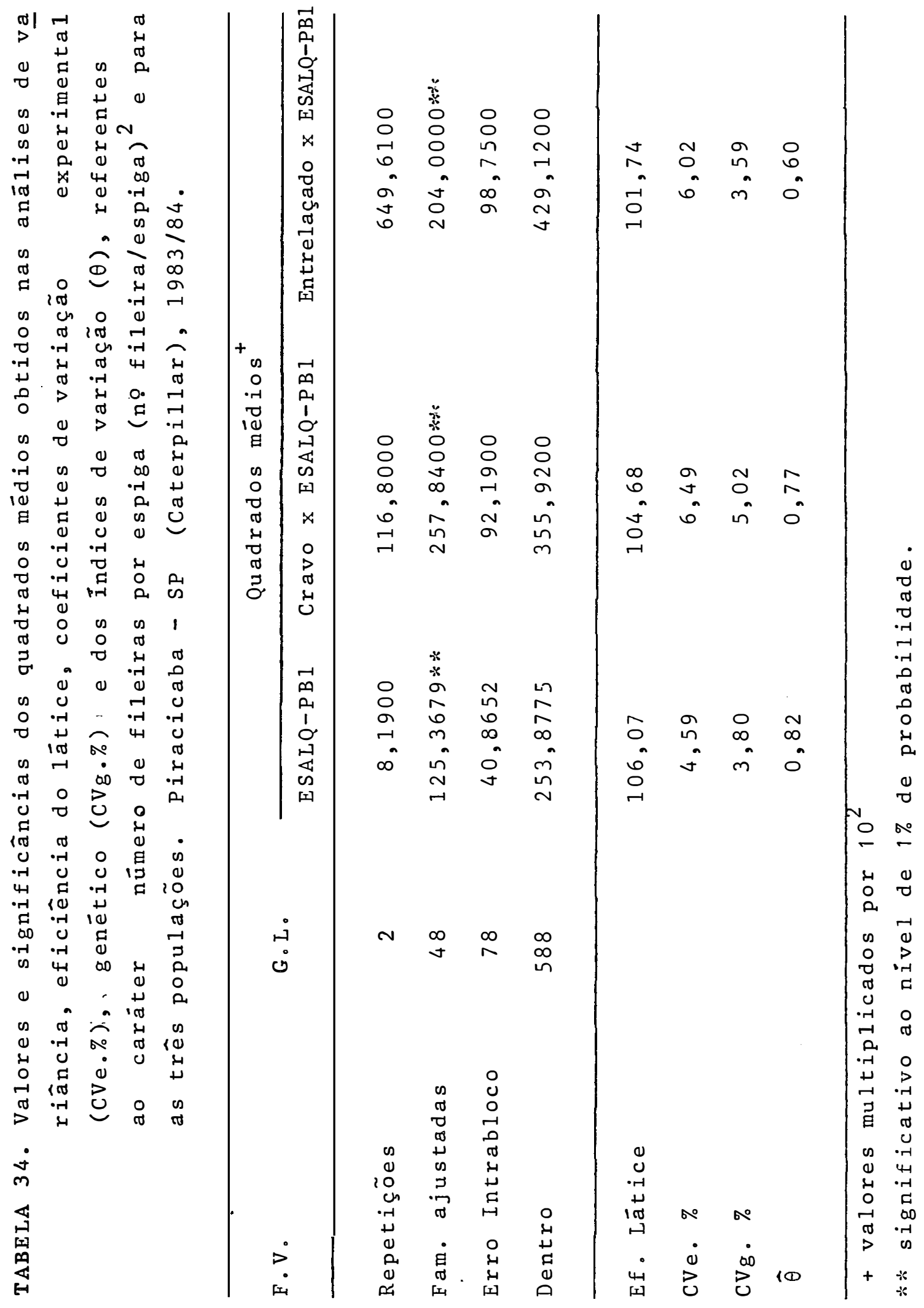


.164.

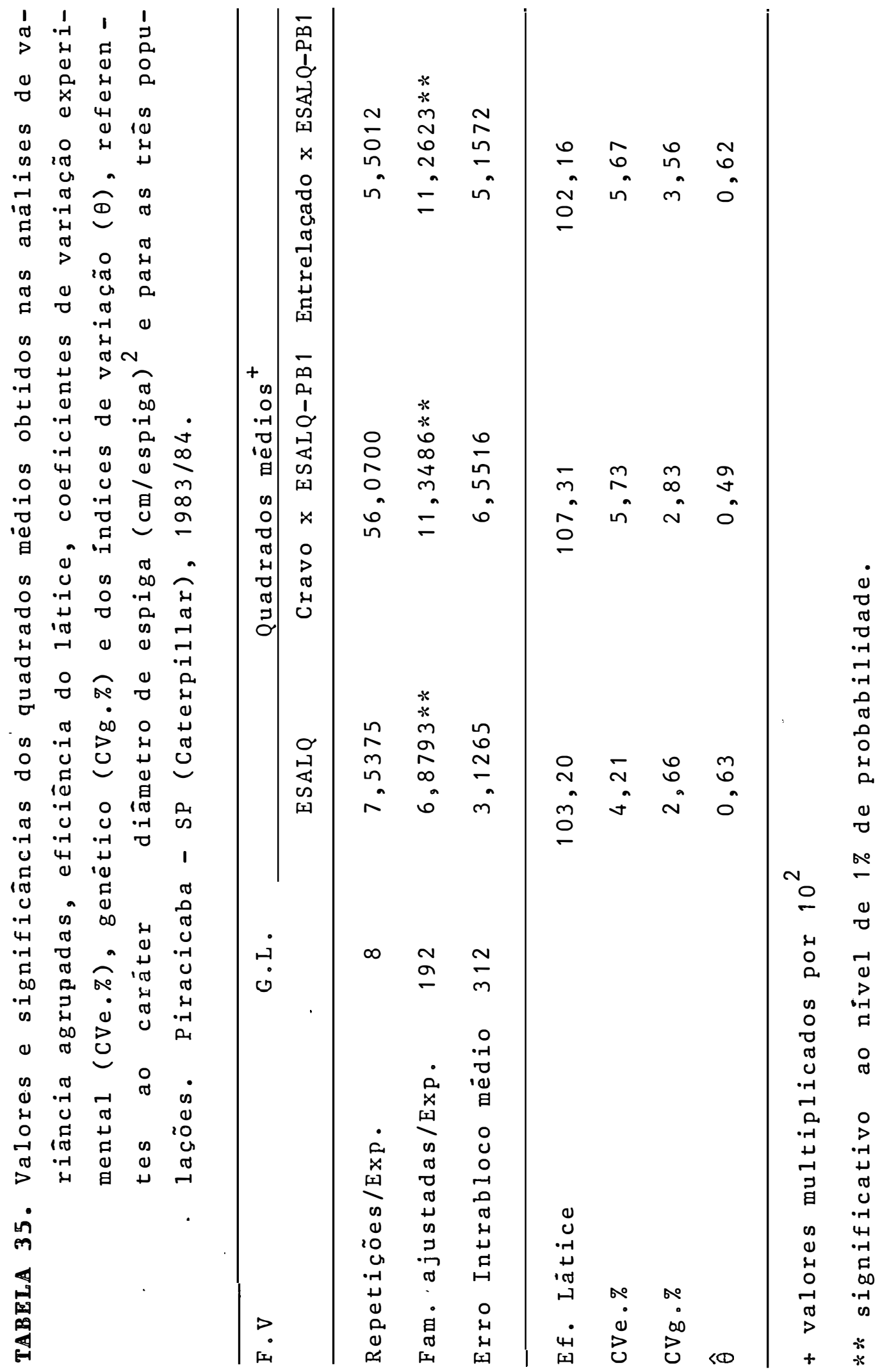




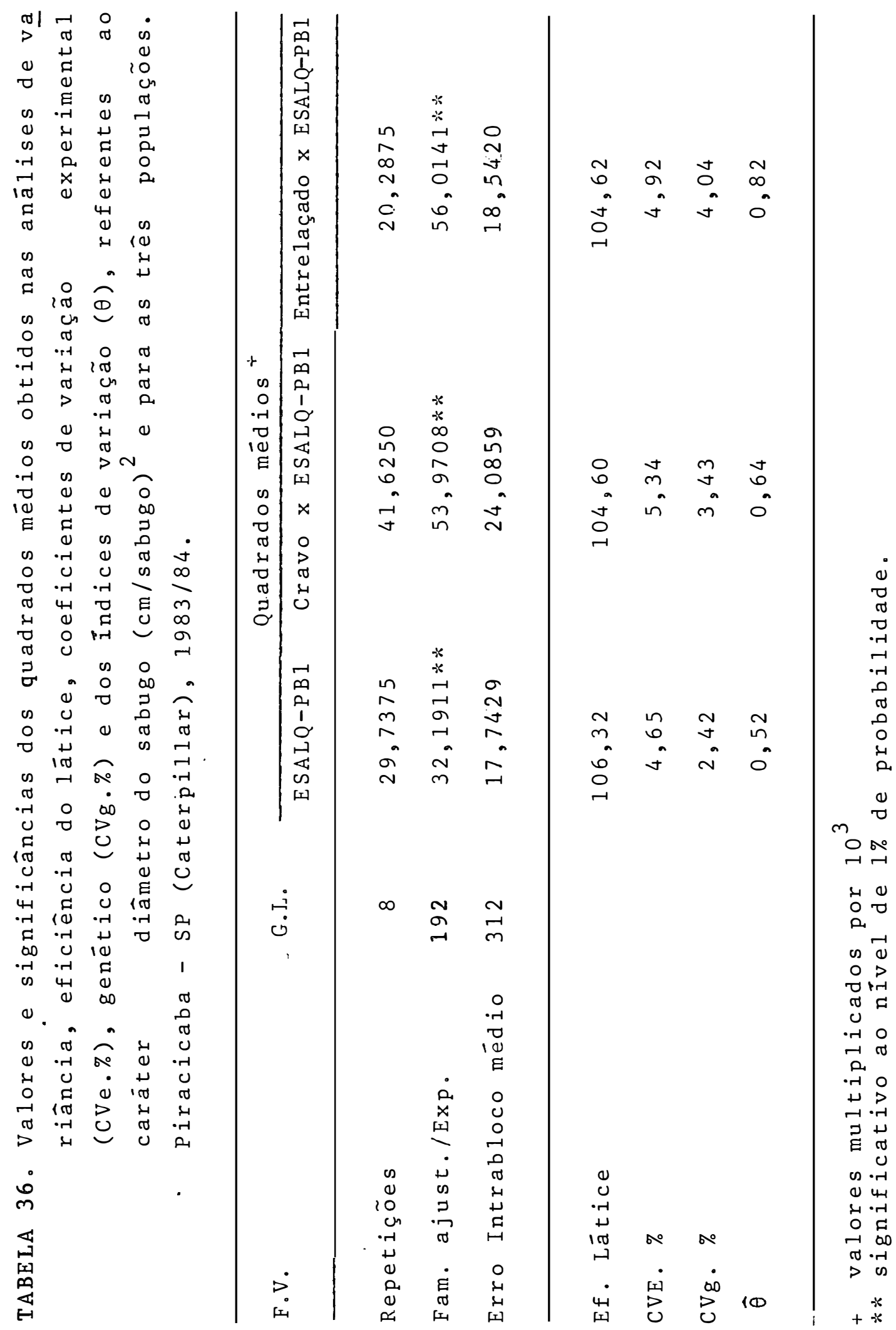


.166.
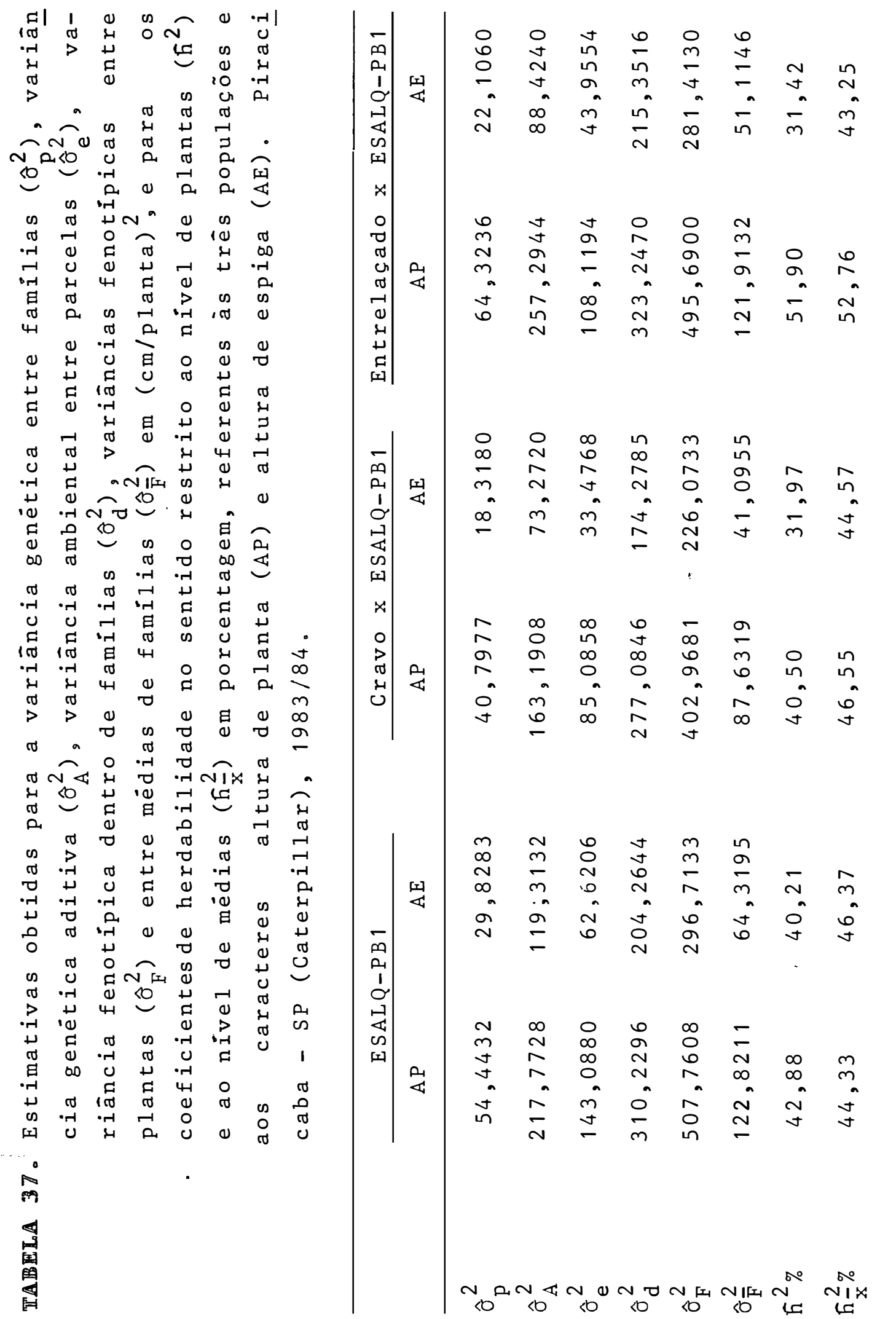


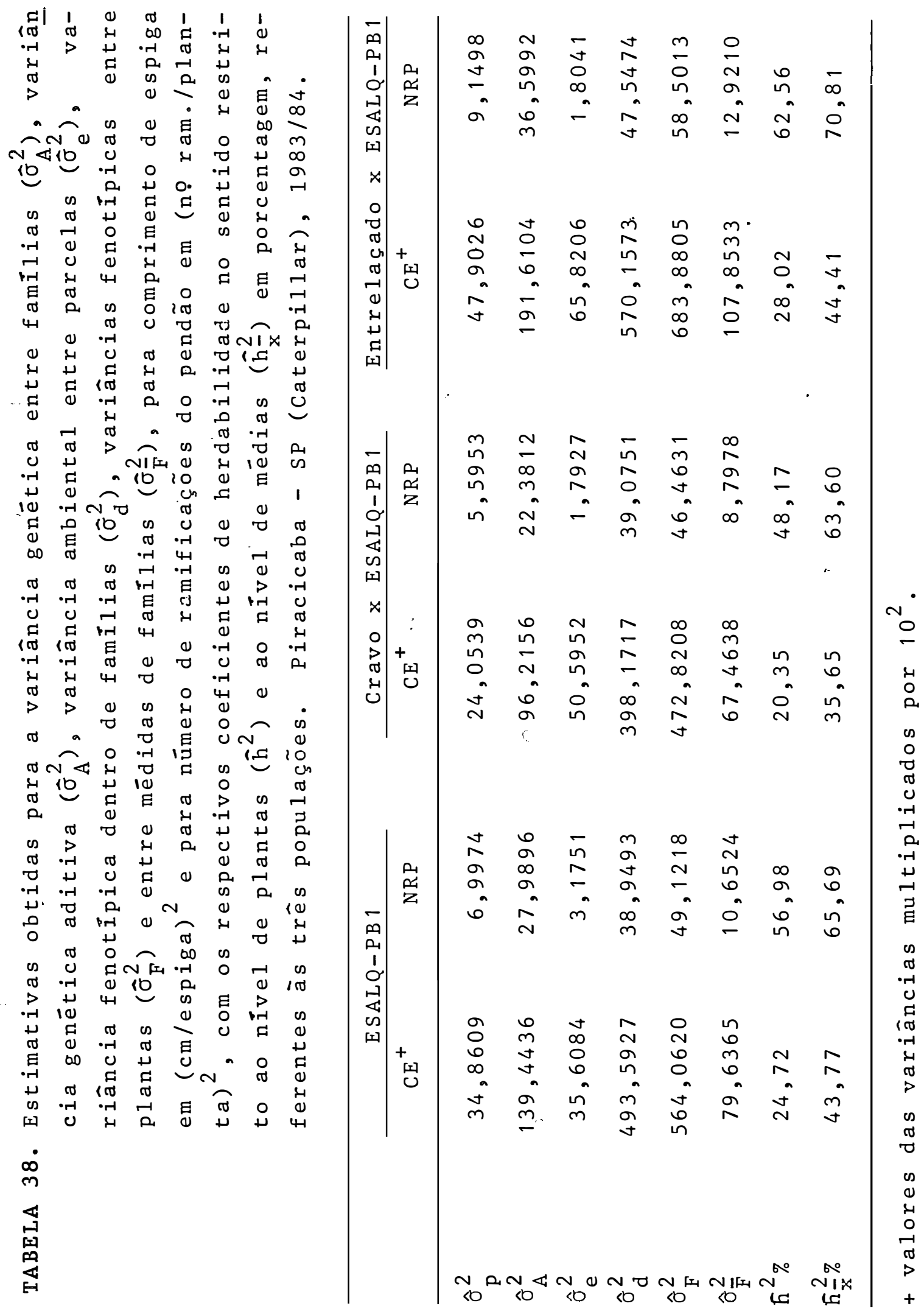


.168.

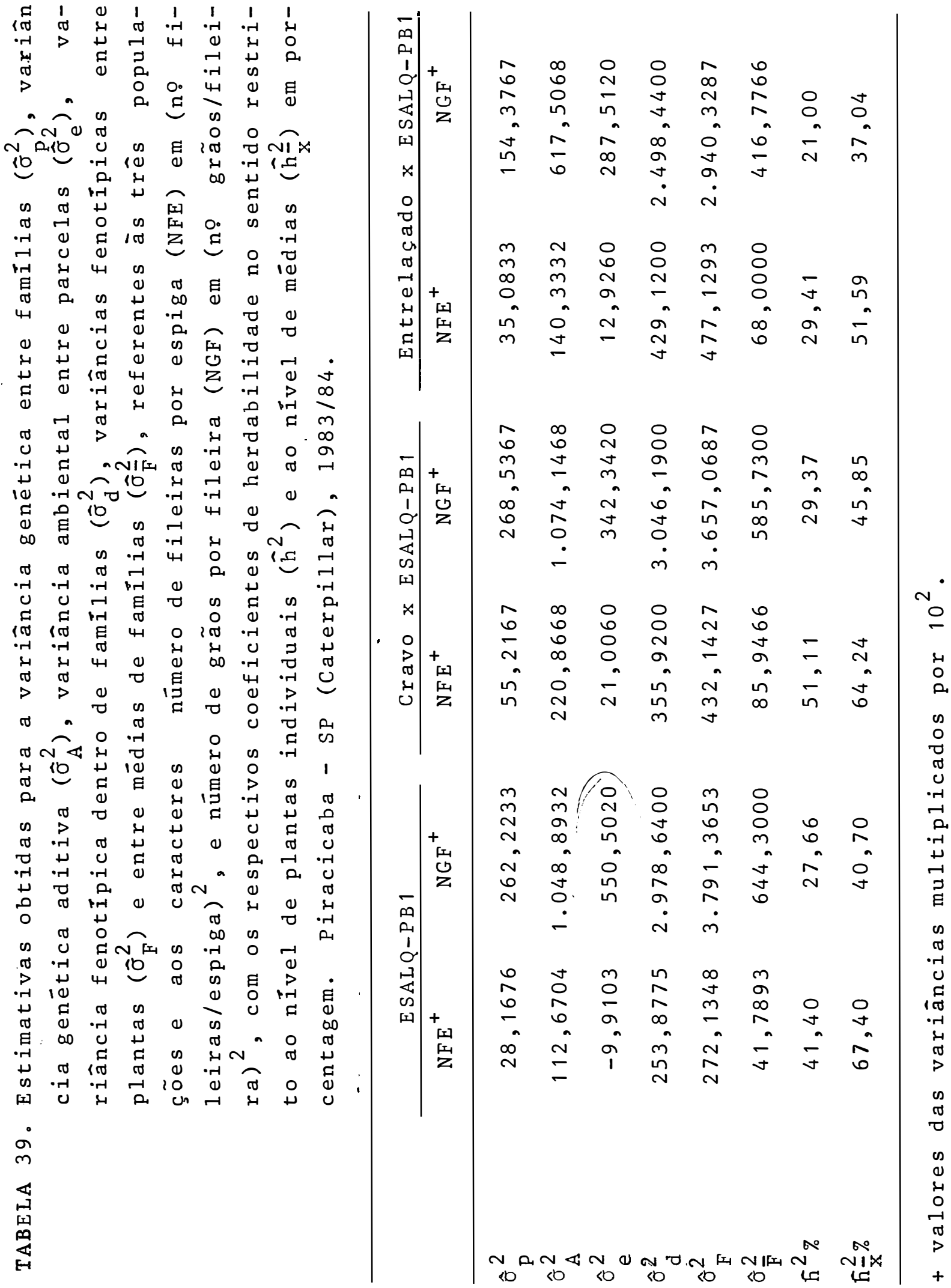




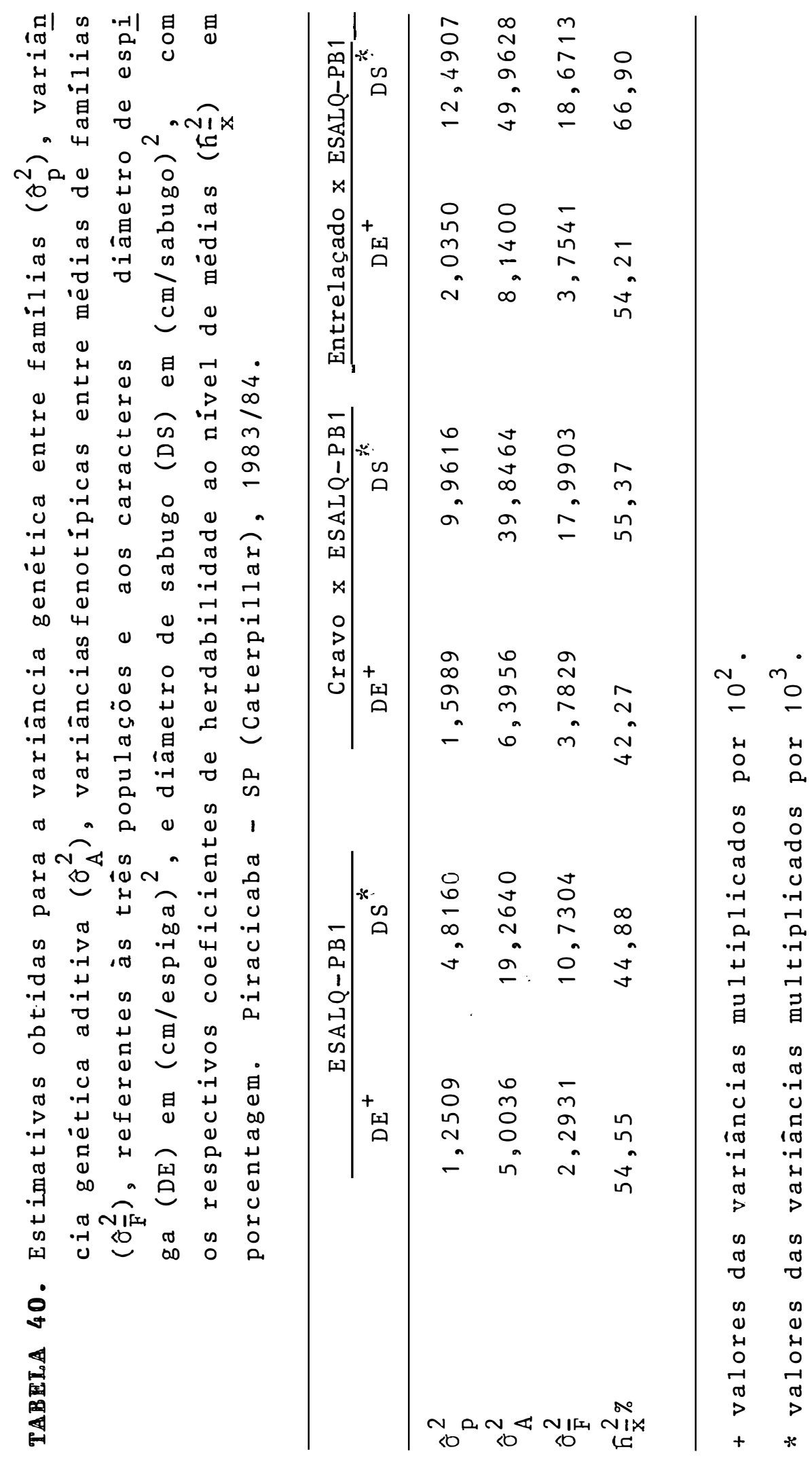


.170 .

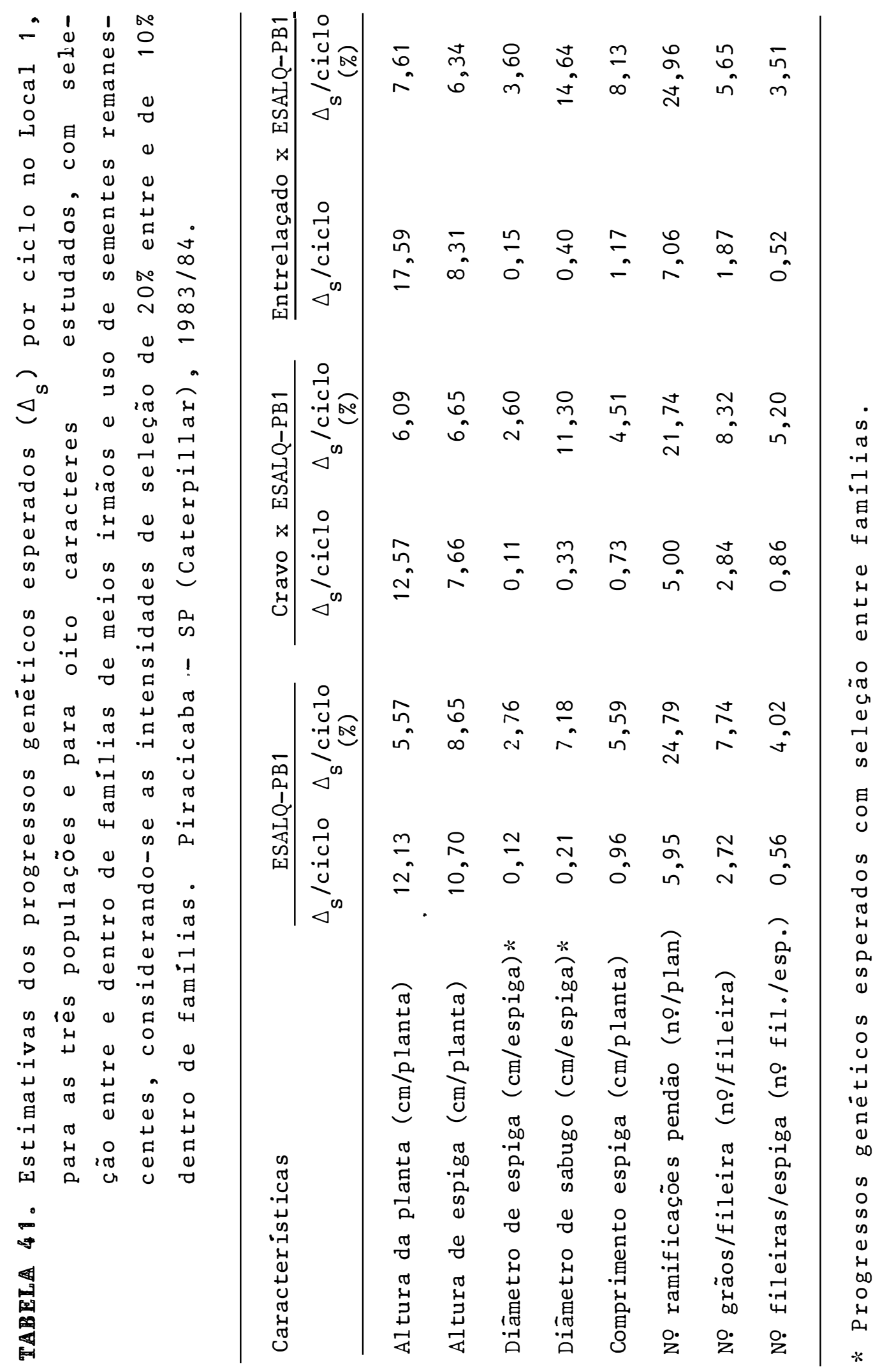


.171.

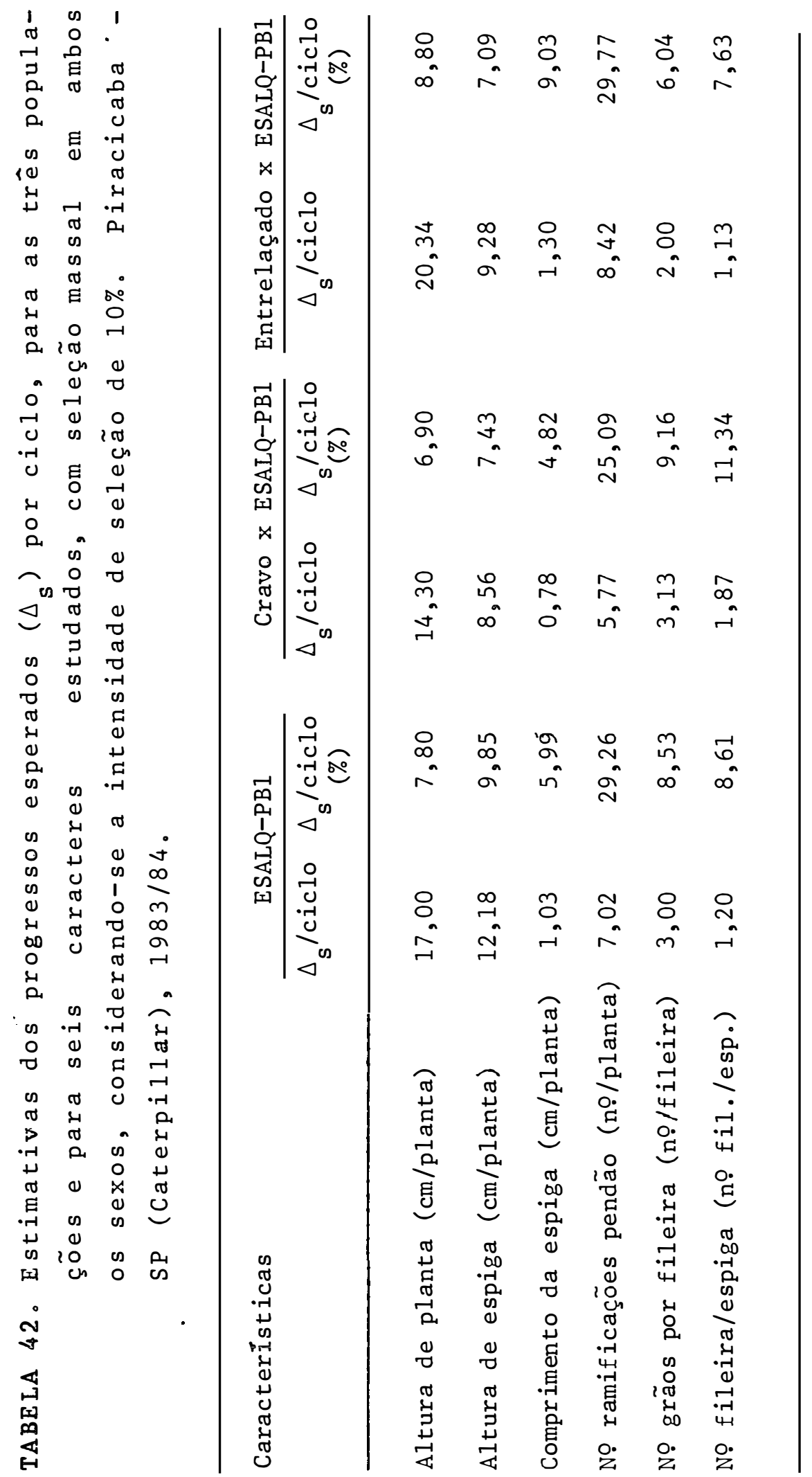


.172 .

\section{Figuras}



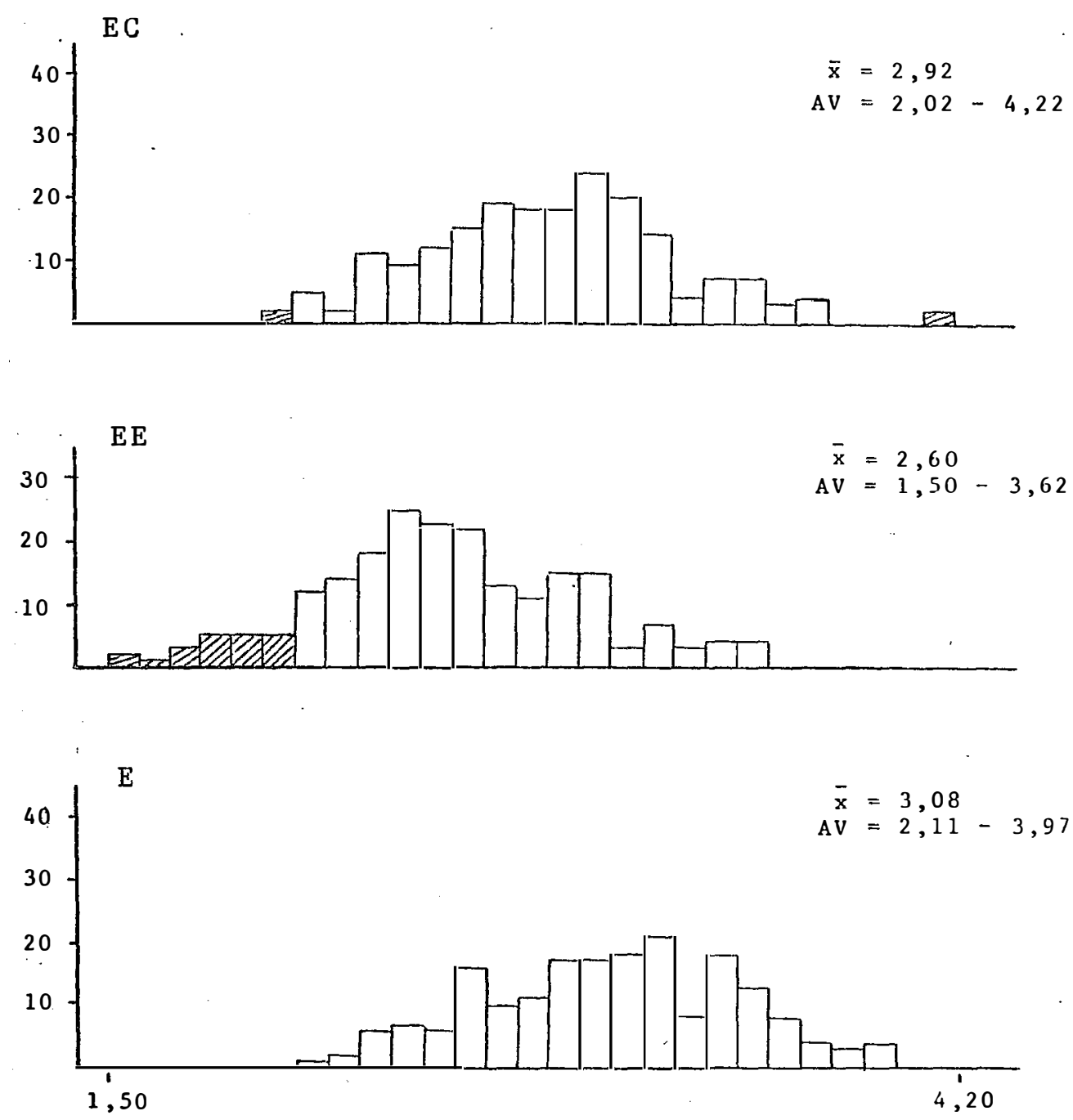

FIGURA 1. Distribuição das médias para peso de espigas (kg/5 $\mathrm{m}^{2}$ ), referente às três populações: EC - Cravo x ESALQ PB1;EE Entrelaçado x ESALQ-PB1 e E - ESALQ-PB1, destacando-se os segregrantes transgressivos (ärea hachurada) em re1 ação à população C; médias de progênies $(\bar{x})$ e amplitu de de variação (AV). (Intervalo de classe $=0,10$ e mé dia das testemunhas $=3,32)$. Milho, Piracicaba - $\overline{\mathrm{P}}$ (Caterpillar), $1983 / 84$. 

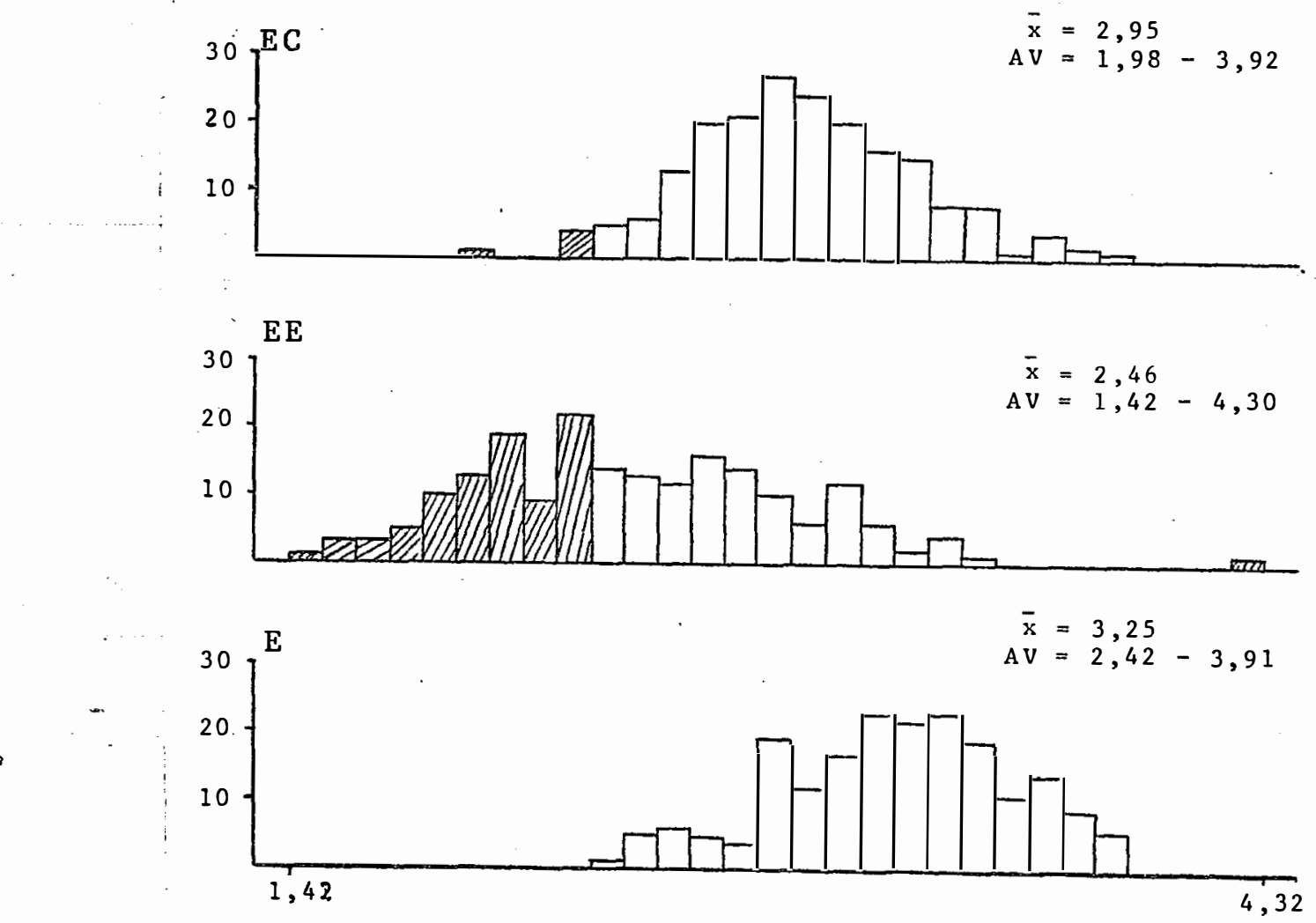

FIGURA 2. Distribuição das médias para peso de espigas (kg/ $5 \mathrm{~m}^{2}$ ), referente às três populações:EC - Cravo x ESALQ-PB1;EE - Entrelaçado x ESALQ-PB1; E - ESALQ$P B 1$, destacando-se os segregantes transgressivos (área hachurada) em relação à população C; médias de progênies ( $\bar{x})$ e amplitude de variação (AV). (Intervalo de classe $=0,10$ e média das testemunhas $=3,60)$. Milho. Piracicaba-SP (Ägua Santa, $1983 / 84)$. 

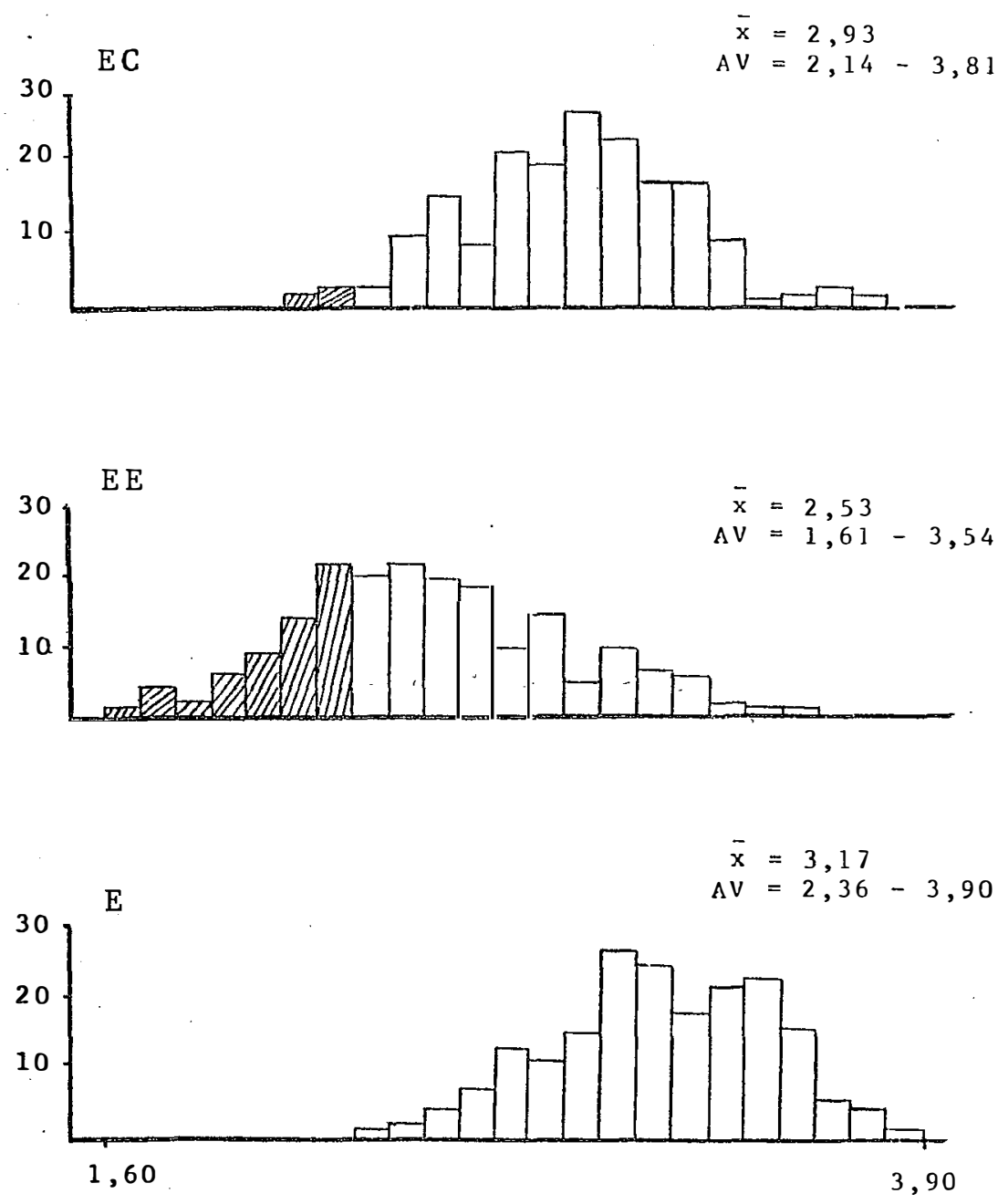

FIGURR 3. Distribuição das médiàs, nos dois locais, para pe so de espigas $\left(\mathrm{kg} / 5 \mathrm{~m}^{2}\right)$, referente às três popula çöes: EC - Cravo X ESALQ-PBI; EE - Entrelaçado ESALQ-PBI e E - ESALQ-PBI, destacando-se os segre gantes transgressivos (ärea hachurada) em relação à população C; mêdias de progênies ( $\bar{x})$ e ampli.tude (AV). (Intervalo de classe $=0,10$ e mëdia das testemunhas $=3,46)$. Milho. Piracicaba - SP (C. terpillar e Água Santa), $1983 / 84$. 

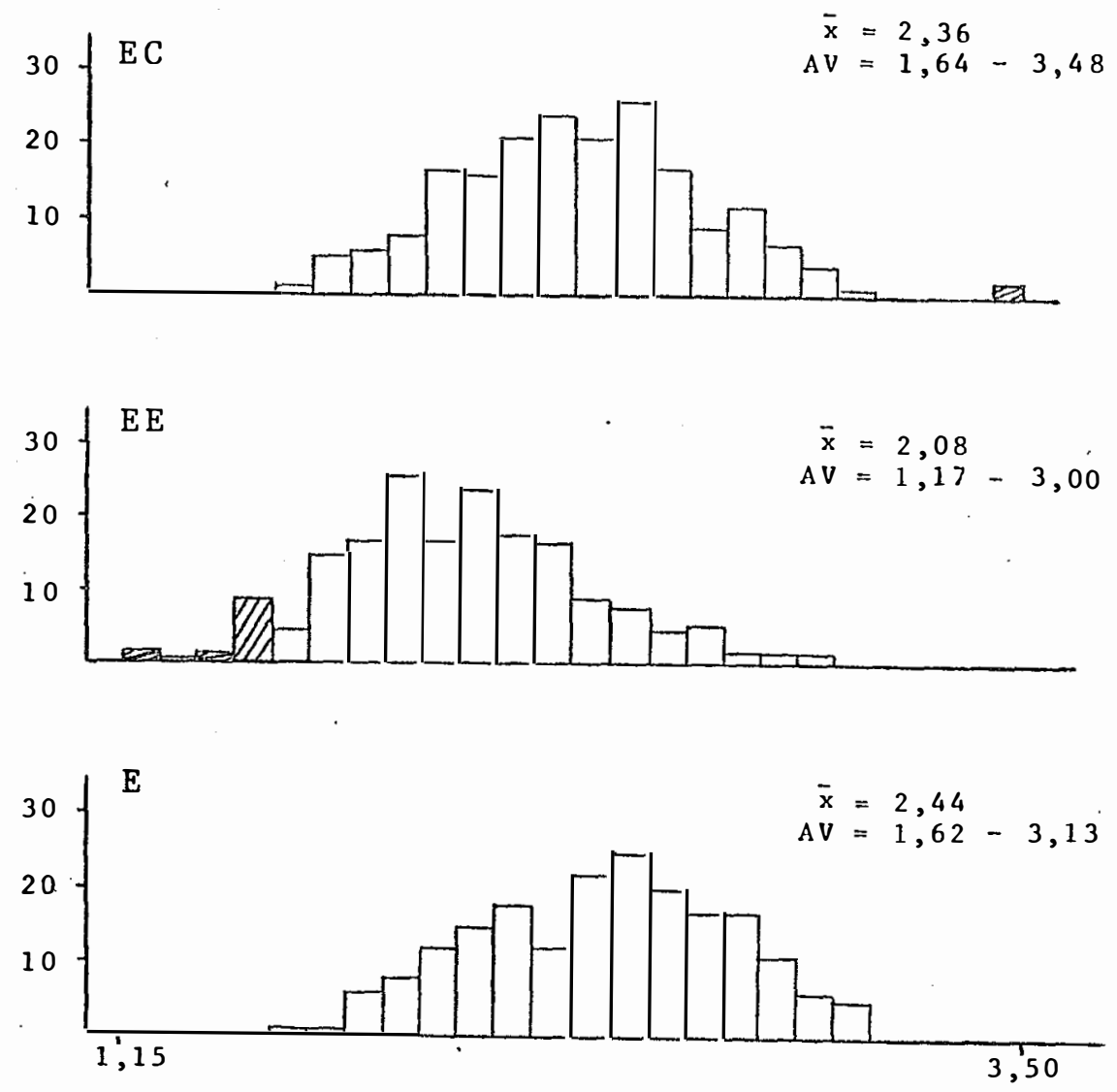

Figura 4. Distribuição das mêdias para peso de grãos (kg/ $5 \mathrm{~m}^{2}$ ), referente às três populações: EC - Cravo x ESALQ -PB 1;EE - Entrelaçado x ESALQ-PB1 e E ESALQ-PB 1, destacando-se os segregantes transgres sivos (ärea hachurada) em relação à população C; médias de progênies $(\bar{x})$ e amplitude de variação $(\mathrm{AV})$. (Intervalo de classe $=0,10$ e mëdia das testemunbas $=2,69$ ). Milho. Piracicaba $-\mathrm{SP}$ ( $\mathrm{C}$ a terpil1ar). $1983 / 84$. 

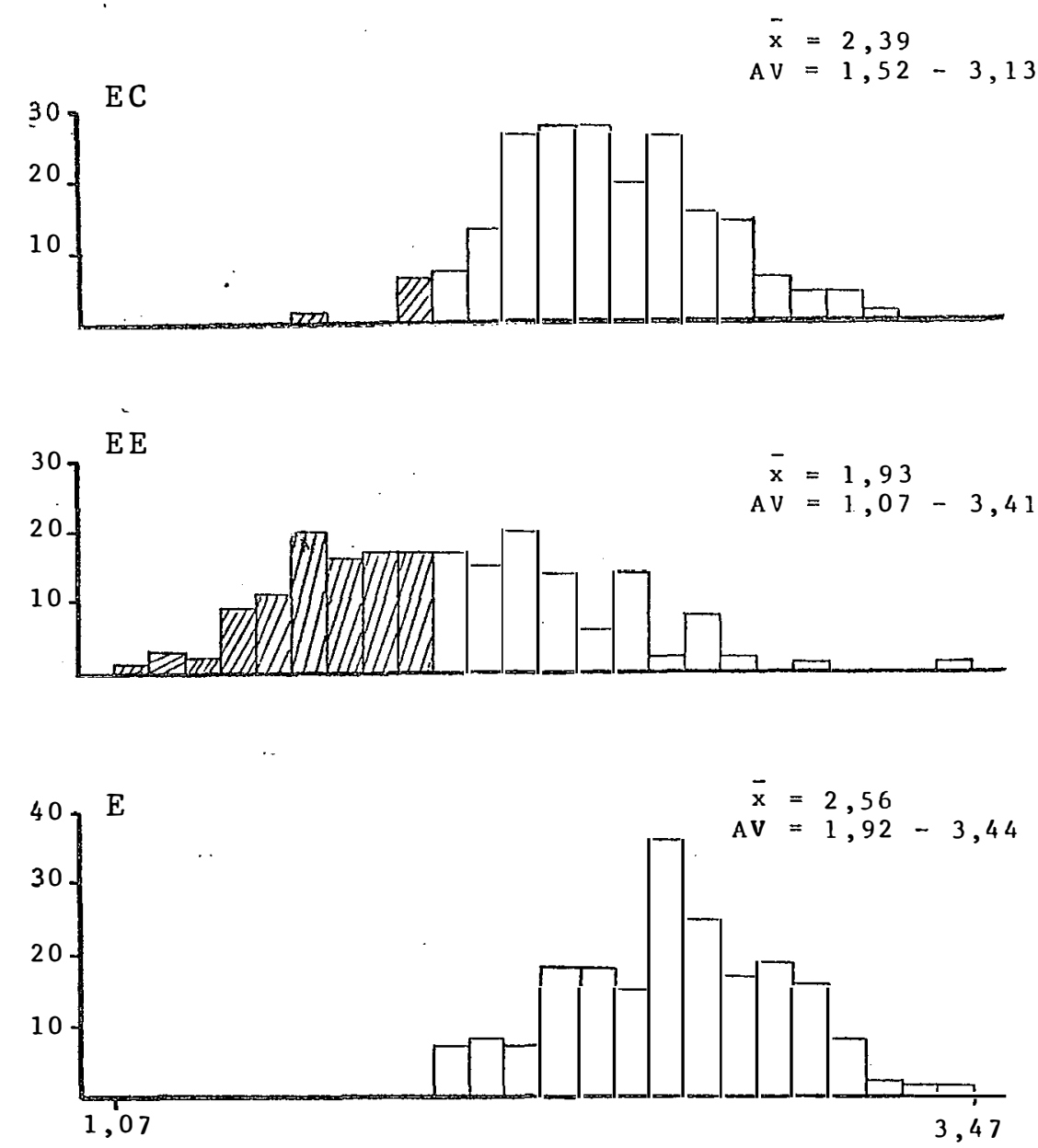

FIGURA 5. Distribuição das médias para peso de grãos (kg/ $5 \mathrm{~m}^{2}$ ), referente às três populações: EC-Cravo $x$ ESALQ-PB1; EE- Entrelaçado x ESALQ-PB1 e E ESALQ-PB 1 , destacando-se os segregantes transgres sivos (ärea hachurada) em relação à população c médias de progênies $(\bar{x})$ e amplitude de variação (AV). (Intervalo de classe $=0,10$ e média das testemunhas $=2,95)$. Milho. Piracicaba - SP (Ägua Santa), $1983 / 84$. 

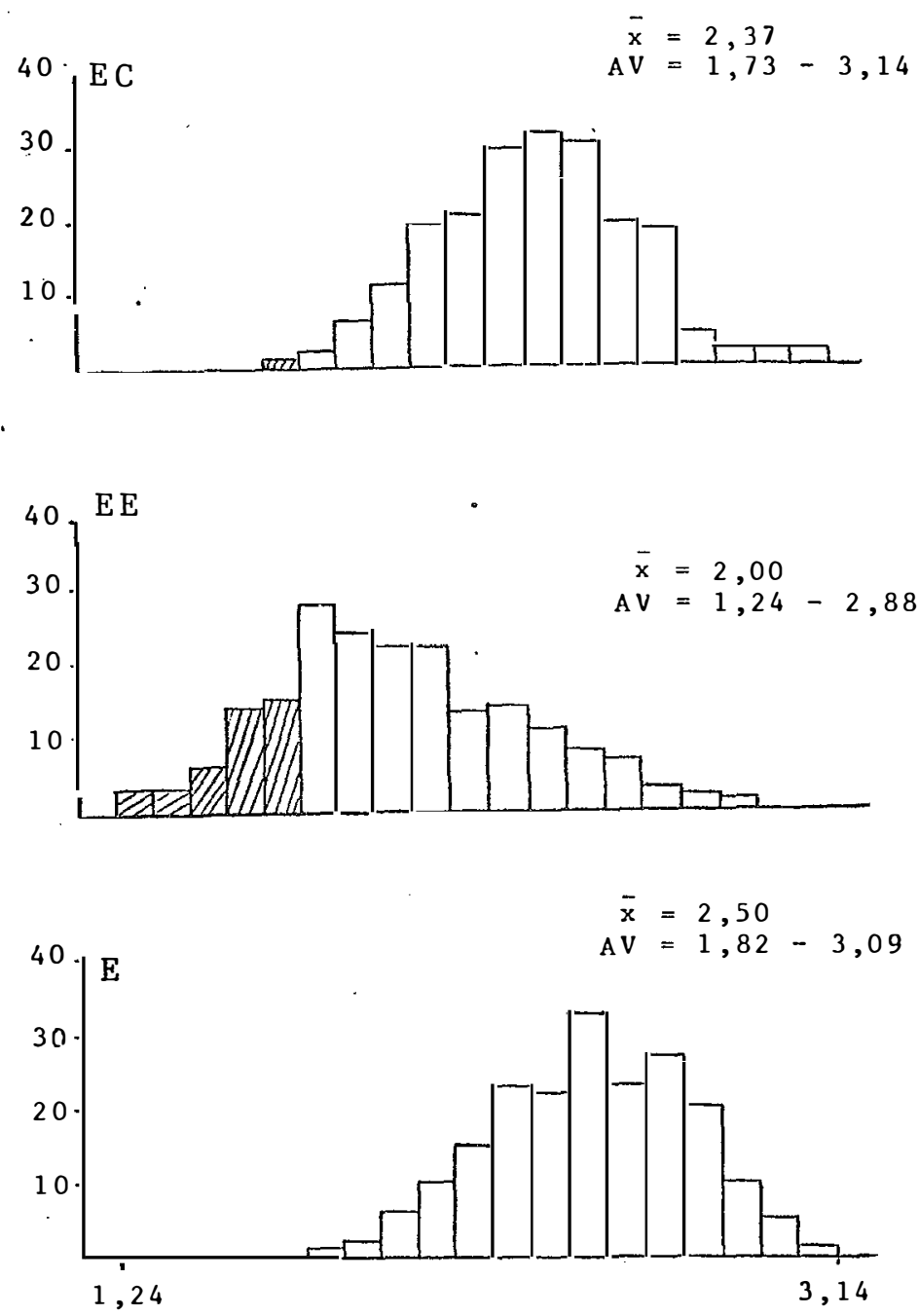

FIGURA 6. Distribui i̧̧ão das médias nos dois locais, para peso de grãos (kg/5 $\left.\mathrm{m}^{2}\right)$, referente às três populações:EC - Cravo x ESALQ-PBl;EE - Entrelaçado $x$ ESALQ-PB1 e E - ESALQ-PB1, destacando-se os segre gantes transgressivos (área hachurada) em relação à população C; médias de progênies $(\bar{x})$ e amplitude de variação (AV). (Intervalo de classe $=0,10$ e mëdia das testemunhas $=2,82)$. Milho. Piracicaba - SP (Caterpil1ar e Ägua Santa)。1983/84. 

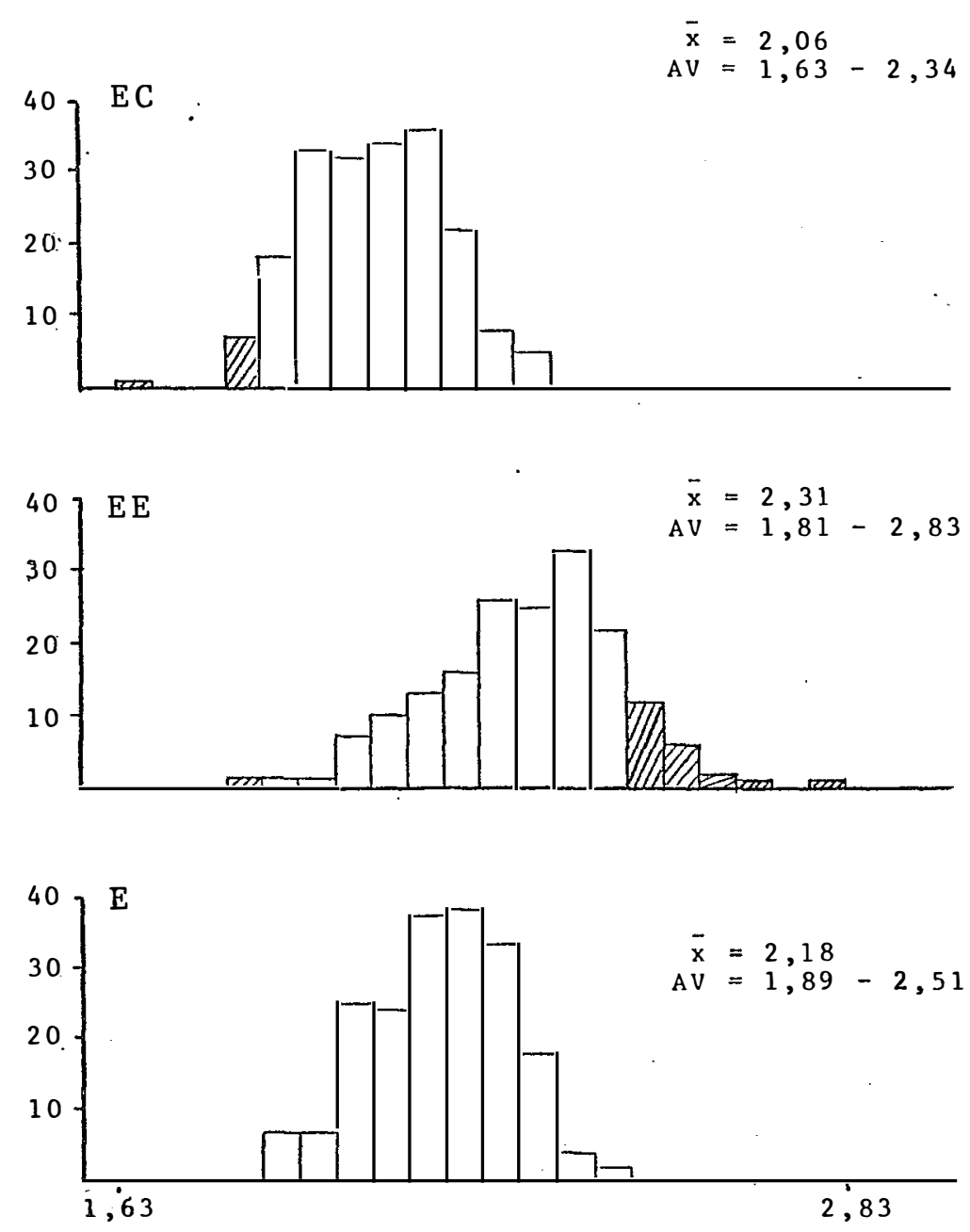

FIGURA 7. Distribuição das médias para altura de planta (m), referente às três populações:EC - Cravo x ESALQ PB 1;EE-Entrelaçado x ESALQ-PBI e E - ESALQ-PBI, destacando-se os segregantes transgressivos (área hachurada) em relação à população $C$; médias de progênies $(\bar{x})$ e amplitude de variação (AV). (Intervalo de classe $=0,06$ e média das testemunhas $=2,15)$. Milho. Piracicaba-SP (Caterpillar), $1983 / 84$ 。 

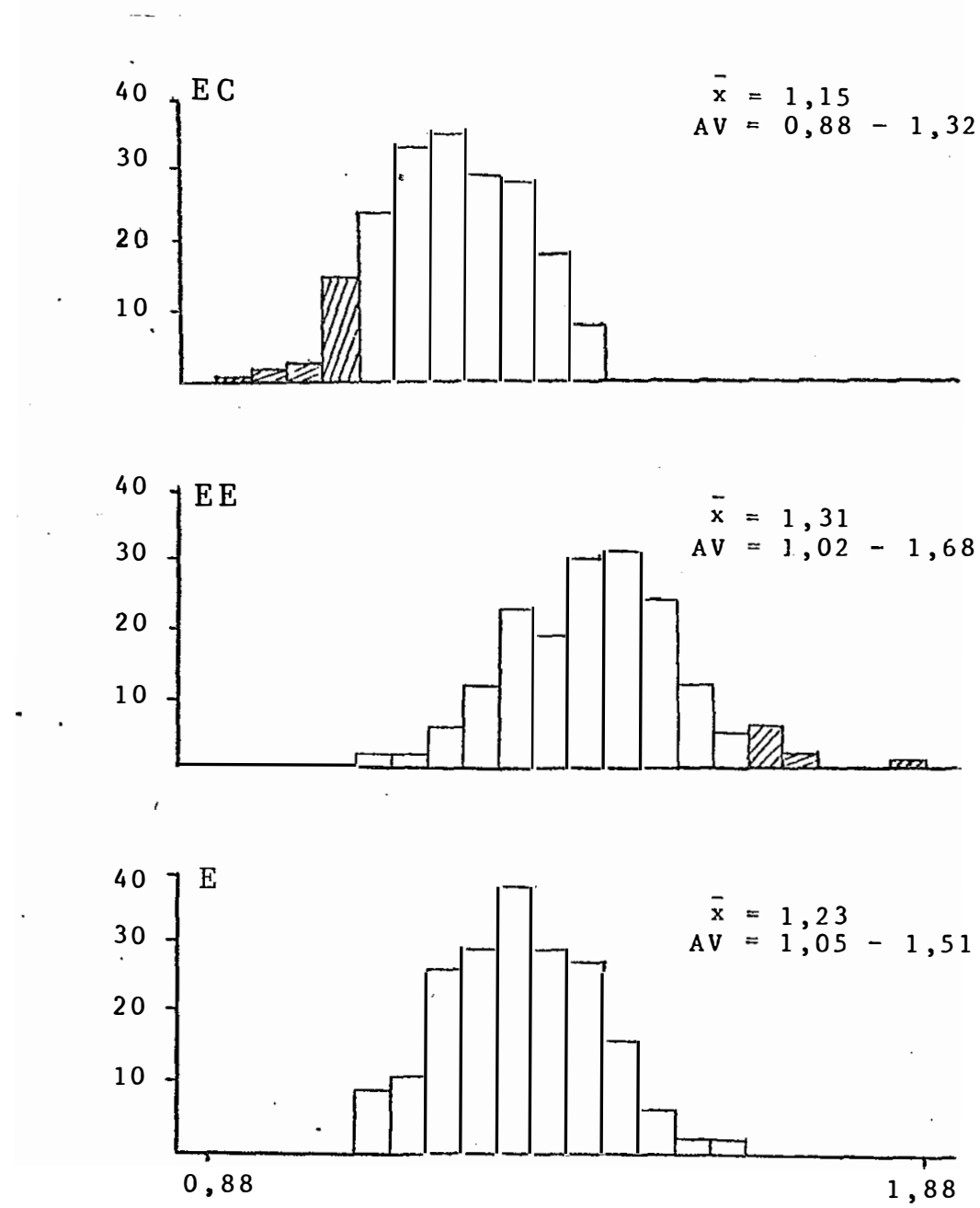

IFIGURA 8. Distribuição das médias para altura de espiga (m), referente às três populações: EC-Cravo x ESALQPB1;EE - Entrelaçado x ESALQ-PB1 e E - ESALQ-PB1, destacando-se os segregantes transgressivos (área hachurada) em relação à população C: médias de progênies ( $\bar{x})$ e amplitude de variação (AV). (Intervalo de classe $=0.04$ e média das testemunhas $=1,22)$. Milho. Piracicaba - SP (Caterpillar), $1983 / 84$. 

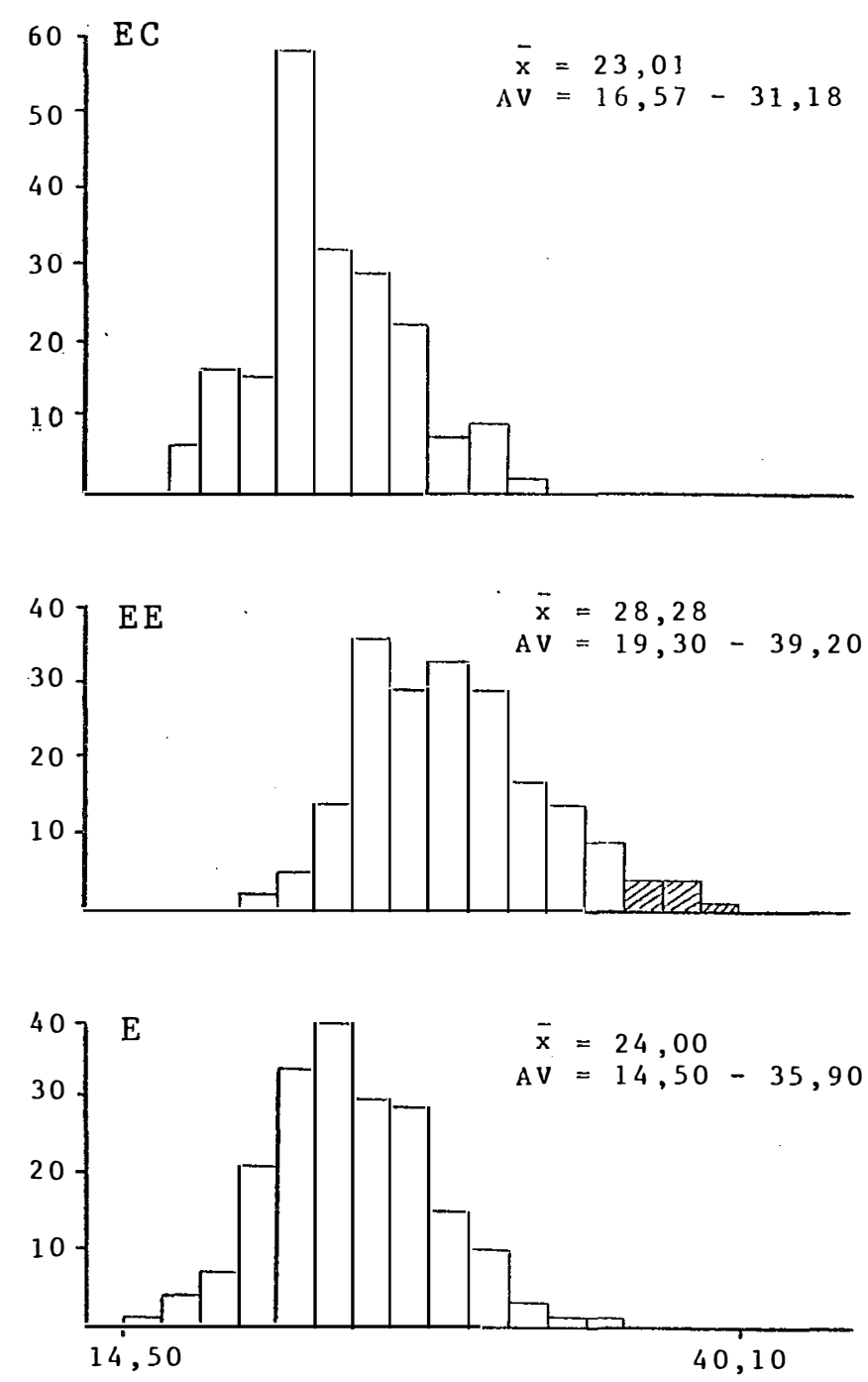

IFIGURA 9. Distribuição das mëdias para nümero de ramificações do pendão (nọ ram./planta), referente às três populações: EC - Cravo x ESALQ-PB 1;EE - Entrelaçado X ESALQ-PB1 e E - ESALQ-PB1, destacando-se os segr $\underset{\sim}{r}$ gantes transgressivos (área hachurada) em re 1 ação à população $C$; médias de progênies $(\bar{x})$ e am plitude de variação (AV). (Intervalo de classe $\equiv$ $1,60$ e mëdia das testemunhas $=21,47)$. Milho. P racicaba - SP (Caterpil1ar), $1983 / 84$. 

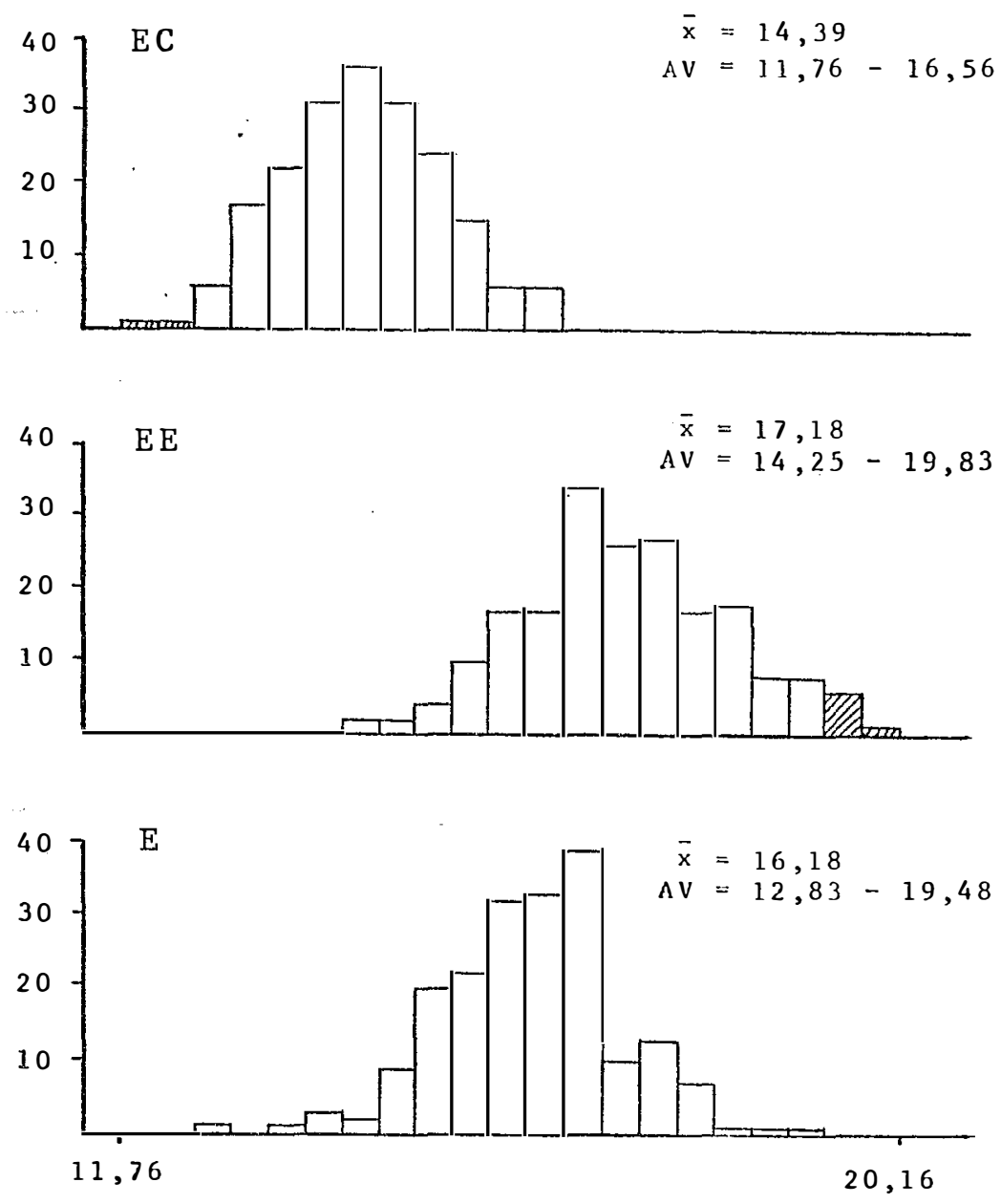

FIGURA 10. Distribuição das médias para comprimento de espí ga (cm), referentes às três populações: EC - Cravo $x$ ESALQ-PB1; EE - Entrelaçado $x$ ESALQ-PB 1 e E - ESALQ-PB1, destacando-se os segregantes transgressivos (ärea hachurada) em relação à população C; média das progênies $(\bar{x})$ e amplitude de variação (AV)。 (Intervalo de classe $=0,40$ e média das testemunhas $=16,80)$. Milho. Piracicaba - SP (Caterpil1ar), 1983/84. 

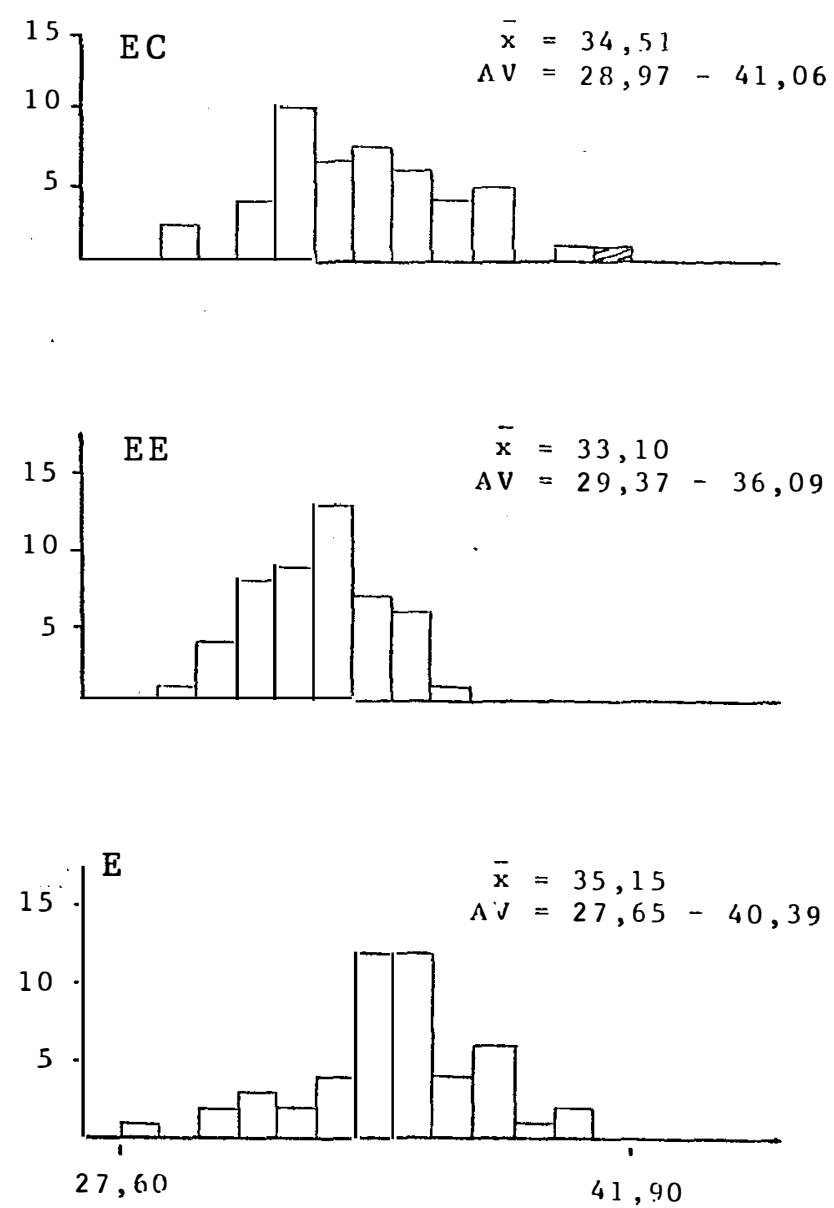

FIGURA 11. Distribuição das médias para nümero de grãos por fileira (no/fileira), referente às três populações : EC - Cravo x ESALQ-PBl; EE - Entrelaçado x ESALQ-PB1 e E - ESALQ-PB1, destacando-se os segregantes transgressivos (área hachurada) em re1 ação à populaçăo $C$; médias de progênies ( $\bar{x})$ e amplitude de variação (AV). (Intervalo de classe $=1,1$ e média das testemunhas $=37,38)$. Mi1ho. Piracicaba - SP (Caterpillar), 1983/84. 

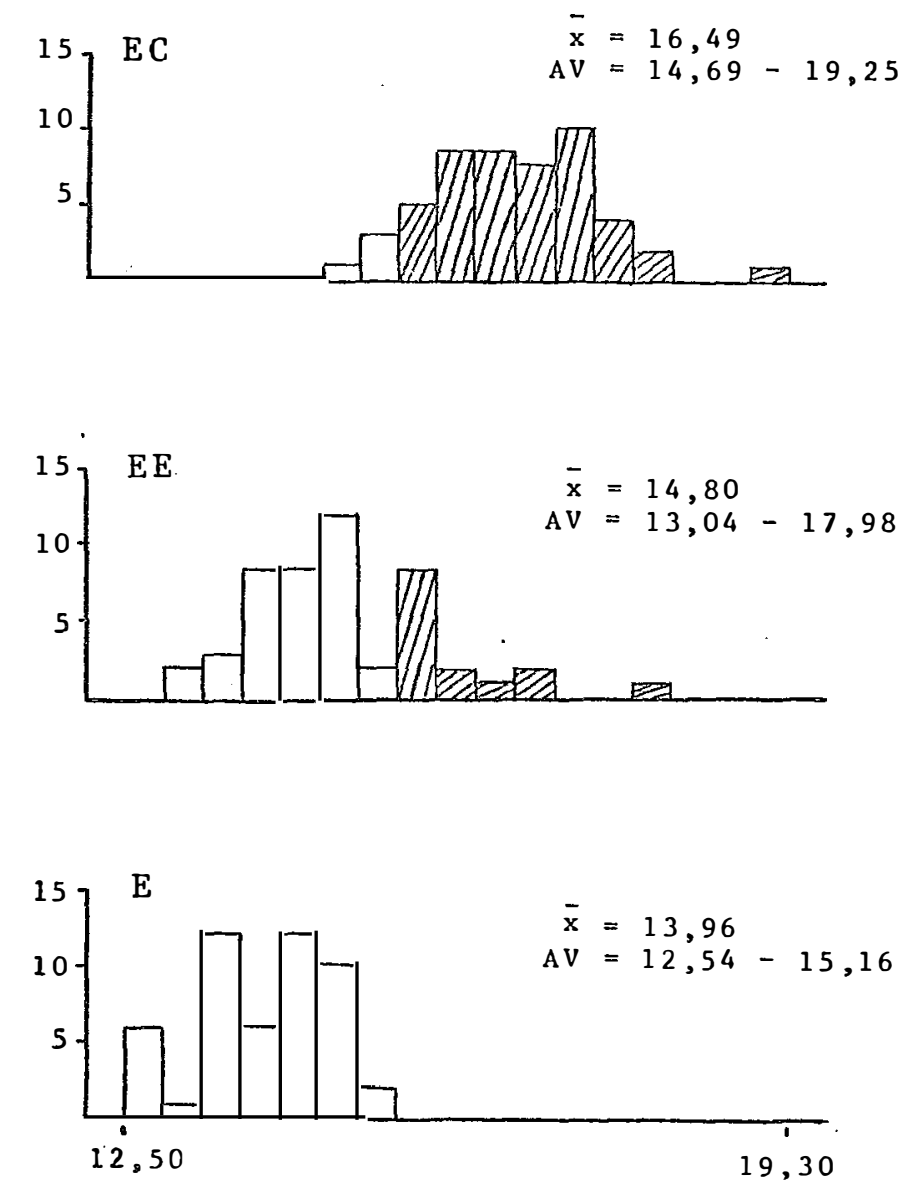

PIGURA 12. Distribuição das médias para número de fileiras por espiga (no fil-/espiga), referente às três populações:EC - Cravo x ESALQ-PBl;EE- Entrelaçadox ESALQ-PB1 e E-ESALQ-PB1, destacando-se os segregantes transgressivos (ärea hachurada) em re1 ação à população $C$ : médias de progênies ( $\bar{x})$ e amplitude de variação (AV). (Intervalo de classe $=0,40$ e média das testemunhas $=13,35)$. Mi1ho. Piracicaba - SP (Caterpillar), $1983 / 84$. 

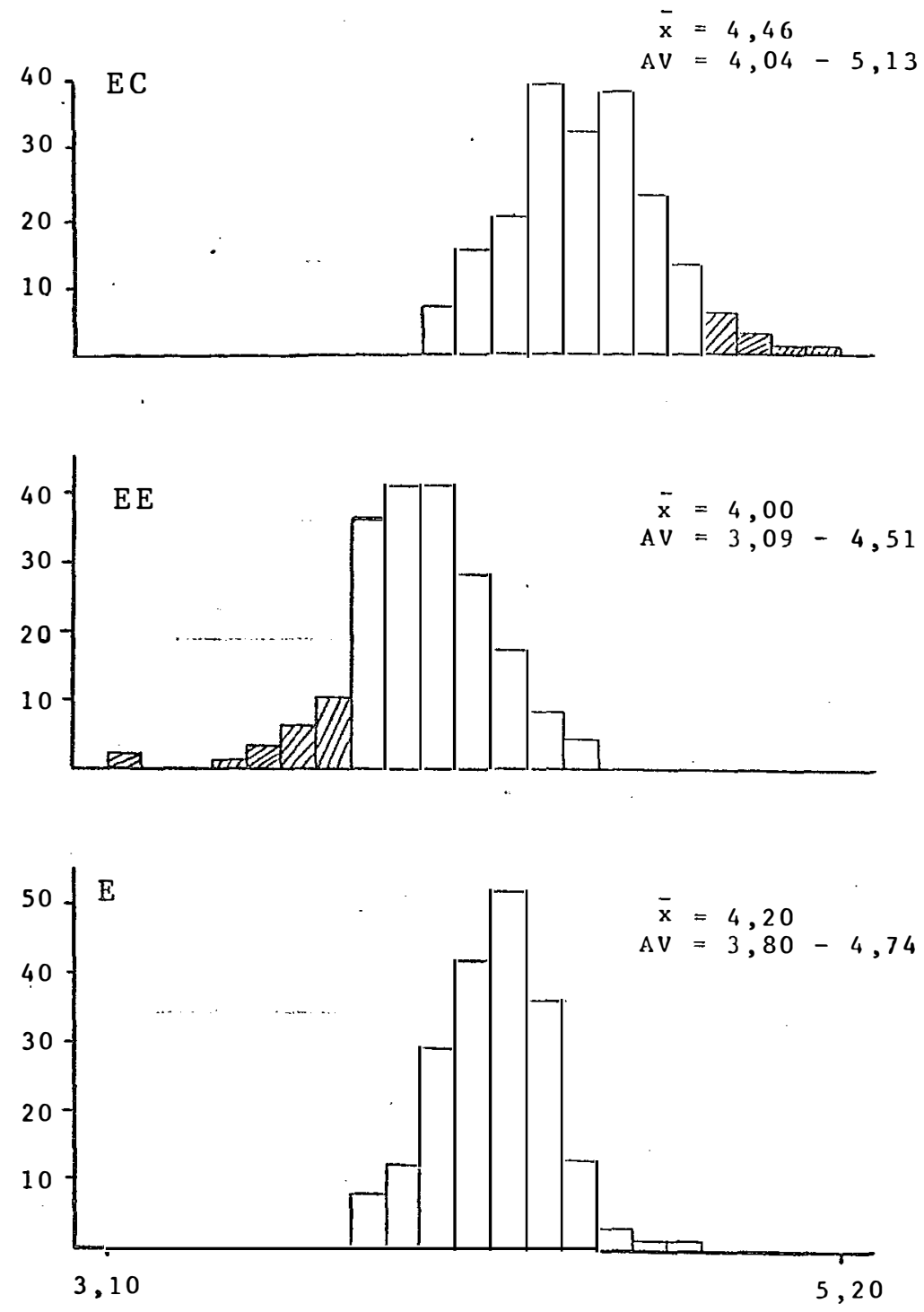

FIGURA 13。" Distribuição das mēdias para diâmetro de espiga (cm), referente às três populações: EC - Cravo x ESALQ-PB 1;EE - Entrelaçado x ESALQ-PB1 e E ESALQ-PB 1, destacando-se os segregantes transgressivos (área hachurada) em relação à população C; médias de progênies $(\bar{x})$ e amplitude de va riação (AV). (Intervalo de classe x 0,10 e média das testemunhas $=4,12)$. Milho. Piracicaba - SP (Caterpil1ar), 1983/84. 

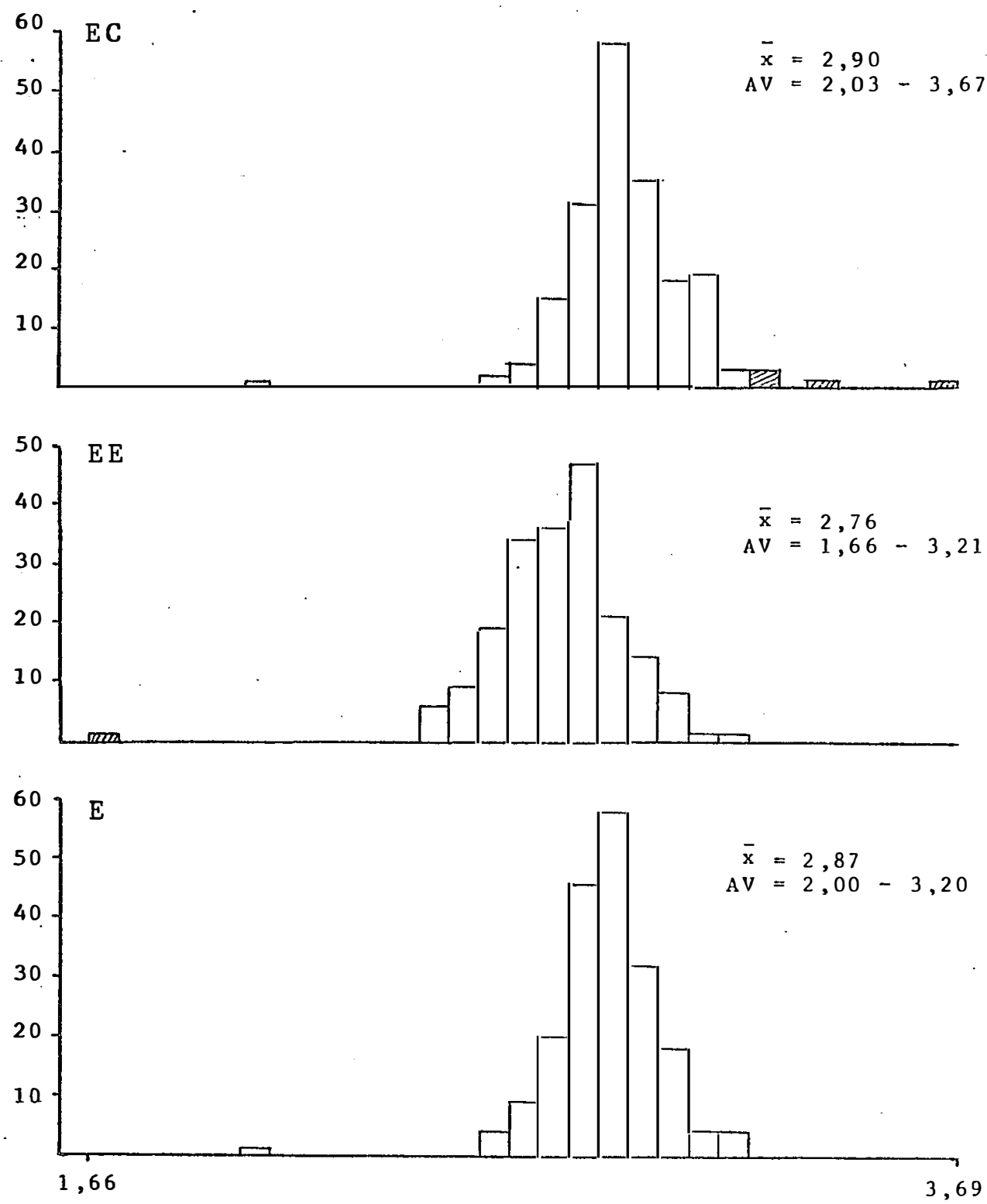

INIGURA 14. Distribuição das médias para diâmetro de sabugo (cm), referente às três populações: EC-Cravo x ESALQ-PB 1;EE-Entrelaçado X ESALQ-PB1 e E ESALQ-PB 1 , destacando-se os segregantes transgressivos (ärea hachurada) em relação à população C; médias de progênies $(\bar{x})$ e amplitude de va riação (AV). (Intervalo de classe $=0,07$ e média das testemunhas $=2,79)$. Milho. Piracicaba (Caterpillar), $1983 / 84$. 